\author{
UNIVERSIDADE DE SÃO PAULO \\ INSTITUTO DE ENERGIA E AMBIENTE \\ PROGRAMA DE PÓS-GRADUAÇÃO EM CIÊNCIA AMBIENTAL
}

ANA KARINA SILVA BUENO

A OFERTA DE ÁREAS PARA O MERCADO DE TERRAS DE COMPENSAÇÃO DE RESERVA LEGAL PARA A CONSOLIDAÇÃO TERRITORIAL DAS UNIDADES DE CONSERVAÇÃO: UM ESTUDO PARA O BIOMA CERRADO 


\section{A OFERTA DE ÁREAS PARA O MERCADO DE TERRAS DE COMPENSAÇÃO DE RESERVA LEGAL PARA A CONSOLIDAÇÃO TERRITORIAL DAS UNIDADES DE CONSERVAÇÃO: UM ESTUDO PARA O BIOMA CERRADO}

Tese apresentada ao Programa de Pós-Graduação em Ciência Ambiental (Procam) do Instituto de Energia e Ambiente da Universidade de São Paulo para a obtenção do título de Doutora em Ciência Ambiental.

Orientador: Prof. Dr. Paulo Antonio Almeida Sinisgalli

\section{Versão Corrigida}

(versão original disponível na Biblioteca do Instituto de Energia e Ambiente e na Biblioteca Digital de Teses e Dissertações da USP)

SÃO PAULO

2018 
AUTORIZO A REPRODUÇÃO E DIVULGAÇÃO TOTAL OU PARCIAL DESTE TRABALHO, POR QUALQUER MEIO CONVENCIONAL OU ELETRÔNICO, PARA FINS DE ESTUDO E PESQUISA, DESDE QUE CITADA A FONTE.

BUENO, Ana Karina Silva

A oferta de áreas para o mercado de terras de compensação de reserva legal para a consolidação territorial das Unidades de Conservação: um estudo para o bioma Cerrado / Ana Karina Silva Bueno: orientador Paulo Antonio de Almeida Sinisgalli -- São Paulo, 2018.

$232 \mathrm{f}$.

Tese (Doutorado - Programa de Pós-Graduação em Ciência Ambiental) -, Universidade de São Paulo, 2018.

1. Código Florestal. 2. Governança de terras. 3. Compensação de Reserva Legal. 4. Unidades de Conservação. 5. Cerrado. I. Sinisgalli, Paulo Antonio de Almeida, orientador. II. Título. 
Nome: BUENO, Ana Karina Silva

Título: A oferta de áreas para o mercado de terras de compensação de reserva legal para a consolidação fundiária e territorial das Unidades de Conservação: um estudo para o bioma Cerrado

Tese apresentada ao Programa de PósGraduação em Ciência Ambiental (Procam) do Instituto de Energia e Ambiente da Universidade de São Paulo para a obtenção do título de Doutora em Ciência Ambiental.

Aprovado em: 27 de agosto de 2018

Banca Examinadora

Assinatura

Prof. Dr. Pedro Jacobi - Universidade de São Paulo (USP)

Assinatura

Prof. Dr. Ademar Romeiro - Universidade Estadual de Campinas (Unicamp)

Assinatura

Dr. Cláudio Maretti - Instituto Chico Mendes da Conservação da Biodiversidade (ICMBio)

Assinatura

Dr. Vitor Buckvar Fernandes 
À minha mãe, meu amor, minha fortaleza, meu exemplo de vida. 


\section{AGRADECIMENTOS}

Em primeiro lugar, agradeço ao meu Mestre Espiritual pela força e perseverança, principalmente nas horas difíceis.

Ao Professor Dr. Paulo Antonio de Almeida Sinisgalli, pela oportunidade, pela confiança, pelo incentivo, pelo suporte ao longo de todos esses anos e, sobretudo, pelas palavras de confiança que me encorajavam para seguir.

Aos meus pais, Sérgio Bueno e Ana Maria Silva, meu porto seguro. Agradeço de coração por tê-los como pais. Tudo que sou vem de vocês.

A Bastiaan Philip Reydon, pelo companheirismo, pela ajuda, pelo carinho, pelo amor, por caminhar comigo pela vida e pela oportunidade e parceria na temática da governança de terras. Você me presenteou com meus maiores presentes: minha linda família com filhos e enteados.

Aos meus filhos, Felipe e Matheus, meus tesouros, minha alegria.

Aos meus padrinhos Zuleika e Décio, pela dedicação por minha família e, em especial, por mim. Agradeço por tudo que fazem e fizeram por mim, principalmente nos tempos de tribulações. Vocês têm um lugar especial no meu coração.

À minha prima Mimie, sempre presente na minha vida, principalmente nas horas difíceis, como no fim do período da tese.

À minha irmã Ana Paula Bueno, pelo aprendizado compartilhado na temática da vida e da governança de terras.

À família Cavalcanti Stefanutto, pela amizade carinhosa e companheira.

A todos os demais professores, em especial ao Professor Pedro Jacobi, e funcionários do Procam, pelo auxílio e aprendizado proporcionado.

E, por fim, a André Assunção, pelo auxílio prestado com o GIS. 


\section{RESUMO}

BUENO, Ana Karina Silva. A oferta de áreas para o mercado de terras de compensação de reserva legal para a consolidação territorial das Unidades de Conservação: um estudo para o bioma Cerrado. 2018. 232 f. Tese (Doutorado em Ciência Ambiental) - Universidade de São Paulo (USP), São Paulo, 2018.

O Novo Código Florestal (NCF), instituído com a Lei $n^{\circ}$ 12.651/2012, estabelece uma política ambiental de criação de mercado para as propriedades privadas inseridas no interior das Unidades de Conservação (UCs) de domínio público. Essa é uma alternativa de regularização fundiária das UCs, ao mesmo tempo que é um mecanismo atrativo de compra de terras com baixo custo de oportunidade para os proprietários que precisam compensar seus déficits de áreas de Reserva Legal (RL). A pergunta que norteou este trabalho foi a seguinte: diante da debilidade da governança fundiária brasileira, qual o alcance da política de criação de mercado para compensar a área dos imóveis rurais sem RL por áreas tituladas privadas inseridas nos limites das UCs de domínio público, instituído pelo NCF no bioma Cerrado? Evidenciou-se que a ocupação desse bioma (com grandes propriedades monocultoras, com o acelerado avanço da fronteira agrícola e, consequentemente, com o aumento do preço da terra) torna a compensação de RL nessas áreas, pelo mecanismo analisado, bastante atrativa economicamente. Uma vez que o custo de oportunidade da alternativa (de restaurar as áreas de RL deficitárias) é alto por mantê-las com vegetação nativa versus o valor da produção agropecuária na propriedade, visà-vis os preços baixos de terra dessas UCs. A presente tese está alicerçada na discussão teórica sobre política ambiental e governança de terras e tem como objetivo sistematizar uma metodologia que permita aferir a quantidade de áreas existentes nas UCs que podem ser comercializadas neste mercado, ou seja, aquelas que são propriedades privadas. Utilizando os dados de áreas particulares certificadas pelo Incra, no Sistema de Gestão Fundiária (Sigef), que são aquelas georreferenciadas e que possuem matrícula registrada no Cartório de Registro de Imóveis, pode-se aferir a oferta atual de áreas para o mercado de compensação de RL analisado. Para a análise da oferta potencial de áreas a serem transacionadas neste mercado, foram utilizadas as áreas dos imóveis particulares cadastrados no Cadastro Ambiental Rural (CAR). Utilizou-se as camadas de dados individuais no formato shapefile dos limites de UCs, do bioma analisado, das terras indígenas, dos assentamentos rurais e os dados de imóveis rurais disponíveis no CAR e no Sigef. As camadas de dados foram processadas individualmente e depois sobrepostas no ambiente de Sistema de Informações Geográficas (SIG). A partir dessa metodologia, foi possível aferir os conflitos entre essas áreas, como as sobreposições de áreas entre si e a quantidade de área sem cadastro. Conclui-se que a contribuição das áreas ofertadas para o mercado de terras para compensação de RL por doação de área de UC de domínio público na consolidação territorial destas UCs, diante da fragilidade da governança de terras do Brasil, principalmente pela insegurança dos direitos de propriedade, será limitada devido à pouca oferta de áreas disponíveis para esse mercado (cerca de 14,59\% da área total das UCs analisadas), à existência de áreas cadastradas no CAR que podem ou não constituir propriedades e à imensa área sem cadastro no interior das UCs de domínio público do Cerrado (de 49,55\% do total da área).

Palavras-chave: Código Florestal. Governança de terras. Compensação de Reserva Legal. Unidades de Conservação. Cerrado. 


\begin{abstract}
BUENO, Ana Karina Silva. The supply of areas for the land market of legal reserve compensation for the territorial consolidation of Conservation Units: a study for the Cerrado biome. 2018. Thesis (PhD in Environmental Science)-Universidade of São Paulo (USP), São Paulo, 2018.
\end{abstract}

The New Forestry Code (NFC), instituted by the Law No. 12.651/2012, establishes an environmental policy for the creation of a market for the private properties within publicdomain Conservation Units (CUs). This is an alternative for the land regularization of CUs, as well as an attractive mechanism for buying lands at low opportunity cost for owners who need to compensate for their deficits in Legal Reserve areas (LR). The question that guided this work was this: given the weakness of Brazilian land governance, what is the scope of the market creation policy to compensate for the area of rural properties without LR with legally-owned private areas located within the limits of public-domain CUs, instituted by the NFC in the Cerrado biome? Evidences showed that the occupation of this biome (with large properties focused on monoculture farming, accelerated advancement of the agricultural frontier and, consequently, increase of land value) makes the compensation of LR in these areas, by the mechanism analyzed, very attractive economically. Since the cost of opportunity of the other possibility (to restore the areas with deficient LR) is high due to keeping them with native vegetation versus the value of agricultural production in the property, vis-à-vis the low land values of these CUs. This work is based on the theoretical discussion on environmental policy and land governance and aims to systematize a methodology that allows for the identification of the number of areas within the CUs which can be marketed as stated above, that is, which are private properties. Using the data from private areas certified by Incra in their Land Management System (Sigef), which are georeferenced lands and which are legally filed in the Land Registry, it is possible to assess the current availability of areas for the LR compensation market that is analyzed. For the analysis of the potential supply of areas to be negotiated in this market, the areas of private properties registered in the Rural Environmental Register (RER) were used. Individual data layers in shapefile format on the following content were used: the limits of CUs, the analyzed biome, indigenous lands, rural settlements and the data on rural properties available in the RER and Sigef. The data layers were processed individually and then overlapped on the Geographic Information System (GIS) environment. From this methodology, it was possible to assess the conflicts between these areas, such as overlapping of lands and the amount of areas without registration. It was concluded that the contribution of the areas offered to the land market for the compensation of LR by donation of public domain $\mathrm{CU}$ areas in the territorial consolidation of these CUs, in view of the fragility of Brazil's land governance, mainly due to the uncertainty of property rights, will be limited due to the little supply of available areas for this market (about $14.59 \%$ of the total area of the CUs analyzed), the existence of areas registered in the RER that may or might not constitute properties and the immense area without registration inside the public domain CUs of the Cerrado biome $(49.55 \%$ of the total).

Keywords: Forestry Code. Land governance. Legal Reserve compensation. Conservation Units. Cerrado. 


\section{LISTA DE TABELAS}

Tabela 1 - Áreas habilitadas em hectares (ha) e doadas pela compensação de RL para o poder

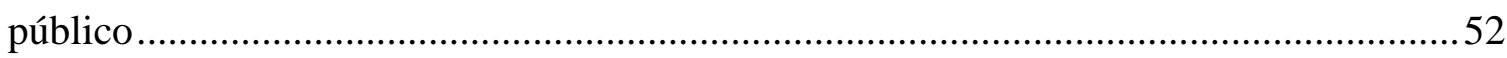

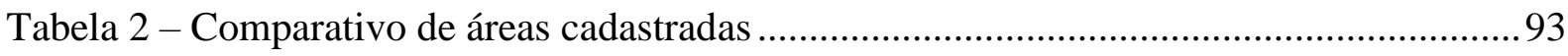

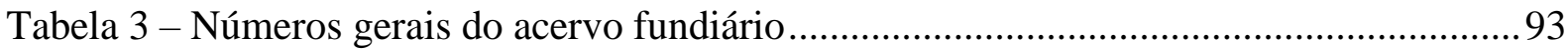

Tabela 4 - Resultados do CAR de agosto de 2016 .............................................................. 104

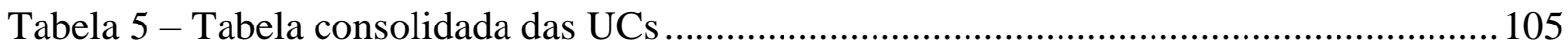

Tabela 6 - UCs cadastradas no CNUC por bioma, em julho de 2017 ................................. 115

Tabela 7 - Situação fundiária dos parques nacionais do Brasil existentes em 2000 .............. 124

Tabela 8 - Situação de 52 parques nacionais brasileiros em relação ao grau ........................ 126

Tabela 9 - Situação fundiária das UCs federais brasileiras de domínio público, por categoria,

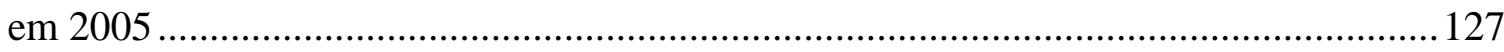

Tabela 10 - Custo estimado para indenização de terras privadas no interior de UCs federais

Tabela 11 - Pendências de regularização fundiária das UCs federais 130

Tabela 12 - Recursos financeiros aplicados em regularização fundiária entre 2009 e 2012.131

Tabela 13 - Porcentagem de bioma Cerrado por estado brasileiro ...................................... 138

Tabela 14 - Uso da terra no bioma Cerrado em relação à área central do bioma .................... 139

Tabela 15 - Cobertura das áreas protegidas nos principais biomas brasileiros - UCs integral, de uso sustentável e terras indígenas.

Tabela 16 - Déficits de APPs e RLs e o total da vegetação nativa desprotegida por bioma em

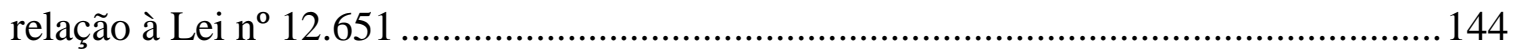

Tabela 17 - Áreas das UCs de proteção integral e uso sustentável no Cerrado..................... 145

Tabela 18 - Diferença de áreas a partir dos dados do CNUC e da área calculada na metodologia de georreferenciamento das UCs de domínio público do Cerrado em milhões de hectares (Mha)

Tabela 19 - Oferta atual, potencial e áreas sem cadastro dos Parnas do bioma Cerrado em hectares (dados de março de 2018) 162

Tabela 20 - Ofertas atual e potencial e áreas sem cadastro das estações ecológicas (EEs) do bioma Cerrado em hectares (dados de março de 2018) 166

Tabela 21 - Ofertas atual e potencial e áreas sem cadastro das reservas extrativistas (Resex) do bioma Cerrado em hectares (dados de março de 2018) 170 
Tabela 22 - Ofertas atual e potencial e áreas sem cadastro das florestas nacionais (Flonas) do bioma Cerrado em hectares (dados de março de 2018) 173

Tabela 23 - Ofertas atual e potencial e áreas sem cadastro das reservas biológicas (Rebios) do bioma Cerrado em hectares (dados de março de 2018) 176

Tabela 24 - Dados médios das ofertas atual e potencial e das áreas sem cadastros nas UCs de domínio público 178 


\section{LISTA DE FIGURAS}

Figura 1 - Perspectiva global da administração fundiária.................................................. 74

Figura 2 - Mapa dos principais biomas brasileiros ........................................................ 137

Figura 3 - A expansão da fronteira agrícola no Brasil e no bioma Cerrado em diferentes períodos

Figura 4 - Razão entre os preços de terra de lavoura de São Paulo, Paraná e Rio Grande do Sul e os de Mato Grosso, 1970-2000

Figura 5 - Evolução dos preços de terra em locais selecionados do Matopiba versus evolução

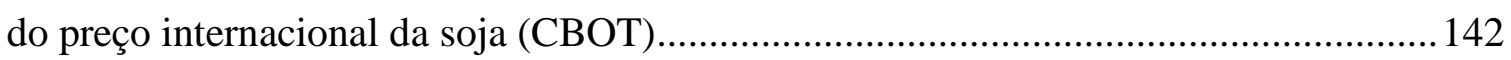

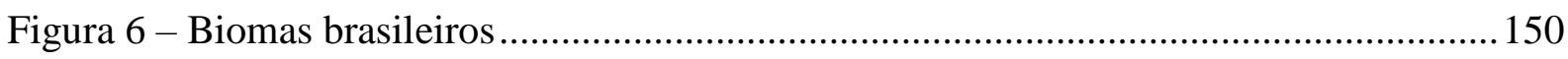

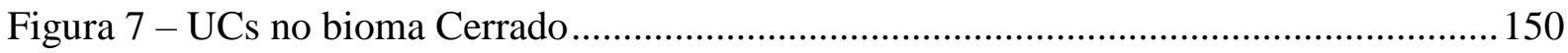

Figura 8 - Estrutura (domínio) fundiária por tipo de proprietário, com base na metodologia de Freitas, Guidotti e Sparovek (2017), para o bioma Cerrado 156 


\section{LISTA DE QUADROS}

Quadro 1 - Principais características da compensação de RL por doação de área em UC de domínio público pendente de regularização fundiária ....................................................55

Quadro 2 - A boa governança e a governança débil ............................................................. 71

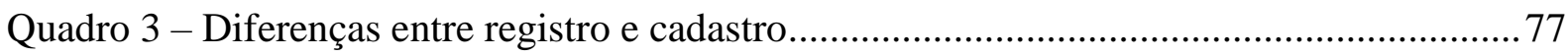

Quadro 4 - Síntese das principais características das diferentes categorias de UCs segundo o SNUC

Quadro 5 - UCs federais de domínio público que não aceitam propriedades privadas em seu interior 148

Quadro 6 - Categorias e fontes dos dados utilizados ....................................................... 149

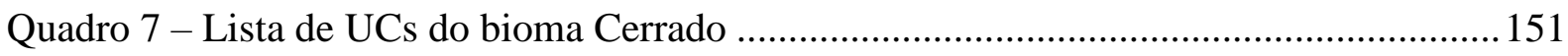

Quadro 8 - Siglas e suas definições das categorias de terras e suas sobreposições de áreas .157 


\section{LISTA DE ABREVIATURAS E SIGLAS}

ADA Ato Declaratório Ambiental

ADI

Ações Direta de Inconstitucionalidade

APA

Área de Proteção Ambiental

APP

Área de Preservação Permanente

Arie

Área de relevante interesse ecológico

Cafir

Cadastro de Imóveis Rurais

CAR

Cadastro Ambiental Rural

CCIR

Certificado de Cadastro de Imóveis Rurais

CNIR Cadastro Nacional de Imóveis Rurais

CNUC Cadastro Nacional de Unidades de Conservação

Conama Conselho Nacional de Meio Ambiente

CRA Cota de Reserva Ambiental

CRF Cota de Reserva Florestal

EE Estação ecológica

FAO Organização das Nações Unidas para a Alimentação e a Agricultura

FIG Federação Internacional de Geômetras

Flona Floresta Nacional

Funai $\quad$ Fundação Nacional do Índio

ha

Hectares

Ibama Instituto Brasileiro do Meio Ambiente e dos Recursos Naturais Renováveis

IBGE Instituto Brasileiro de Geografia e Estatística

ICMBio Instituto Chico Mendes de Conservação da Biodiversidade

IN Instrução Normativa

Incra Instituto Nacional de Colonização e Reforma Agrária

ISA Instituto Socioambiental

ITR Imposto sobre a Propriedade Territorial Rural

MDA Ministério do Desenvolvimento Agrário

MMA Ministério do Meio Ambiente

MN Monumento natural

MP Medida Provisória

MPF Ministério Público Federal

NCF Novo Código Florestal (Lei n ${ }^{\circ}$ 12.651, de 2012) 
OGU Orçamento Geral da União

ONG Organização não governamental

ONU Organização das Nações Unidas

Parna Parque nacional

PRA Programa de Regularização Ambiental

RDS Reserva de desenvolvimento sustentável

Rebio Reserva biológica

Refau Reserva de fauna

Resex Reserva Extrativista

RL Reserva Legal

RPPN Reserva Particular do Patrimônio Natural

RVS Refúgio da vida silvestre

SEMA Secretaria de Meio Ambiente

SIAPA Sistema Integrado de Administração Patrimonial

Sicar Sistema Nacional de Cadastro Ambiental Rural

SIG Sistema de Informações Geográficas

Sigef Sistema de Gestão Fundiária

Sinter Sistema Nacional de Gestão de Informações Territoriais

Sisnama Sistema Nacional de Meio Ambiente

SNCI Sistema Nacional de Certificação de Imóveis

SNCR Sistema Nacional de Cadastro Rural

SNUC Sistema Nacional de Unidades de Conservação

SPU Secretaria do Patrimônio da União

SRF Secretaria da Receita Federal

TCU Tribunal de Contas da União

UC Unidade de Conservação 


\section{SUMÁRIO}

1 INTRODUÇÃO ......................................................................................................................17

2 INSTRUMENTOS DA POLÍTICA AMBIENTAL .......................................................24

2.1 HiSTÓRICO DA POLÍTICA AMBIENTAL NO MUNDO E NO BRASIL ...................................... 24

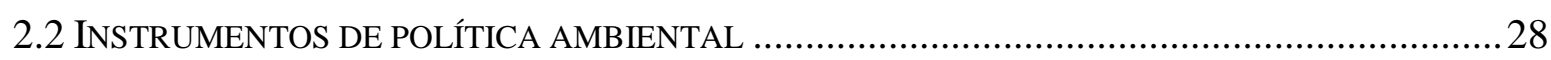

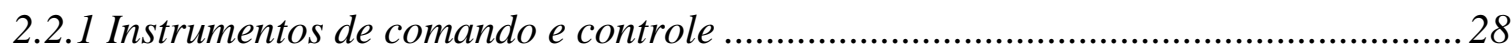

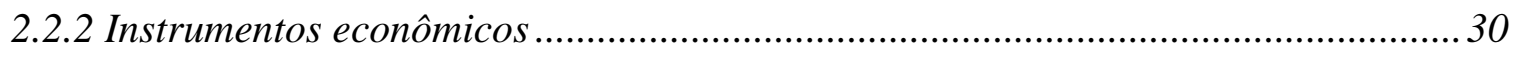

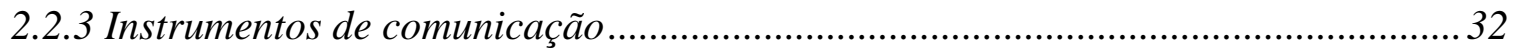

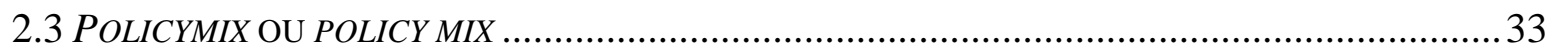

2.3.1 Os instrumentos de policymix na política ambiental do NCF (Lei $n^{o} 12.651$ de 2012)

3 O NOVO CÓDIGO FLORESTAL: AS RESERVAS LEGAIS NAS PROPRIEDADES PRIVADAS E SUA COMPENSAÇÃO POR DOAÇÃO DE ÁREA NAS UNIDADES DE CONSERVAÇÃO.

3.1 OS ESPAÇOS AMBIENTALMENTE PROTEGIDOS: AS UNIDADES DE CONSERVAÇÃO DE DOMÍNIO PÚBLICO E AS ÁREAS DE FLORESTAS PRIVADAS TITULADAS DE RESERVA LEGAL ...................43

3.2 PROPRIEDADE PRIVADA, SUA FUNÇÃO SOCIAL E O NCF .................................................. 44

3.2.1 A Reserva Legal no NCF: regras e diretrizes ......................................................... 46

3.3 O NCF E A COMPENSAÇÃO DE RESERVA LEGAL POR DOAÇÃO DE ÁREA DE UNIDADES DE

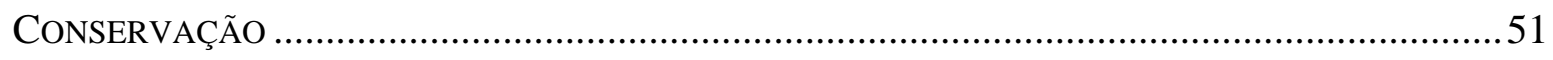

3.4 HistÓRICO DA COMPENSAÇÃO DE RESERVA LEGAL: DA MP № 1.511/96 AO NCF (LEI No

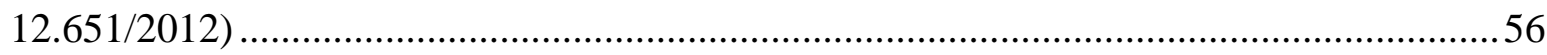

3.5 O NCF E AS AÇÕES DiRETAS DE InCONSTITUCIONALIDADE .......................................... 60

4 GOVERNANÇA E ADMINISTRAÇÃO DE TERRAS: PRINCÍPIOS, CONCEITOS E

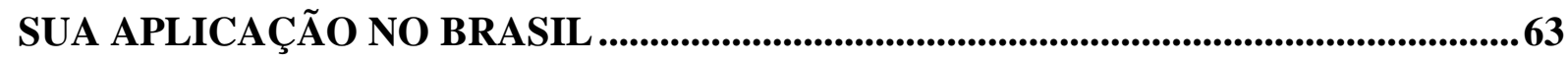

4.1 GOVERNANÇA: UMA BREVE CONTEXTUALIZAÇÃO TEÓRICA .......................................... 63

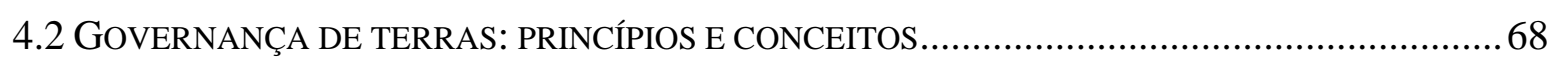

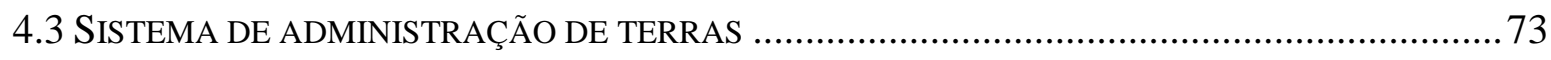

4.3.1 Sistemas de administração de terras: sistema de registro e cadastro ....................... 74

4.4 GOVERNANÇA E SISTEMA DE ADMINISTRAÇÃO DE TERRAS NO BRASIL............................. 77

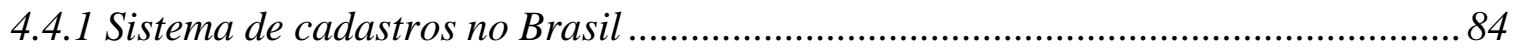


4.4.1.1 Cadastro fundiário: Sistema Nacional de Cadastro Rural (SNCR) 85

4.4.1.2 Cadastro Nacional de Imóveis Rurais (CNIR) .............................................. 88

4.4.1.3 O Sistema de Gestão Fundiária (Sigef) 89

4.4.1.4 Limitações do CNIR, do SNCR e do Sigef decorrentes da fragilidade da governança de terras do Brasil...... 94

4.4.1.5 Sistema Nacional de Gestão de Informações Territoriais (Sinter) 95

4.4.2 Cadastros temáticos 96

4.4.2.1 Cadastro Ambiental Rural (CAR) 97

4.4.2.2 Cadastro Nacional de Unidades de Conservação (CNUC) 104

5 CONSOLIDAÇÃO TERRITORIAL E A REGULARIZAÇÃO FUNDIÁRIA EM UNIDADES DE CONSERVAÇÃO DE DOMÍNIO PÚBLICO NO BRASIL: LIMITES PARA O SEU ALCANCE 107

5.1 A CONSOLIDAÇÃo TERRITORIAL EM UNIDADES DE CONSERVAÇÃo DE DOMÍNIO PÚBLICO: LIMITES PARA SEU ALCANCE 108

6 ANÁlise da OFERTa de Áreas PARA O MERCAdo de TERRAs de COMPENSAÇÃO DE RESERVA LEGAL POR DOAÇÃO DE ÁREA DE UNIDADE DE CONSERVAÇÃO DE DOMÍNIO PÚBLICO NO BIOMA CERRADO. 135

6.1 MeTOdologia DE ANÁLISE do ESTUdo DE CASO DAS UCS DE DOMÍNIO PÚBLICO DO BIOMA CERRADO 135

6.2 DESCRIÇÃO DO BIOMA CERRADO: FATORES AMBIENTAIS E ECONÔMICOS DA ESCOLHA DA

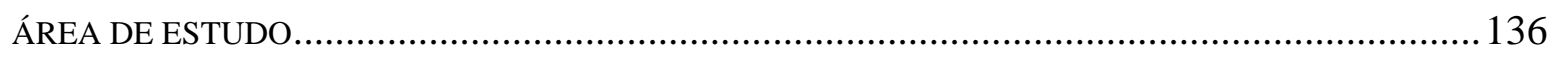

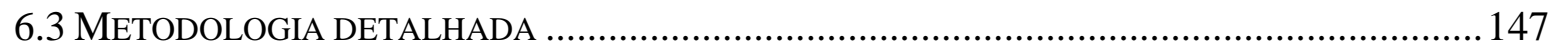

6.3.1 Conflitos fundiários entre Unidades de Conservação de domínio público com terras

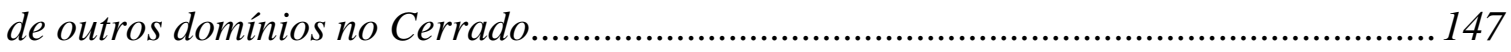

6.3.1.1 Unidades de Conservação no bioma Cerrado............................................... 149

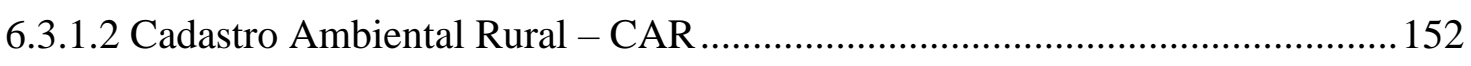

6.3.1.3 Sistema de Gestão Fundiária - Sigef ........................................................ 154

6.3.1.4 Terras indígenas, quilombolas e assentamentos rurais ................................. 155

6.3.2 Dados do Cadastro Nacional de Unidades de Conservação (CNUC) ................... 155

6.3.3 Processamento dos dados das camadas analisadas ............................................. 155

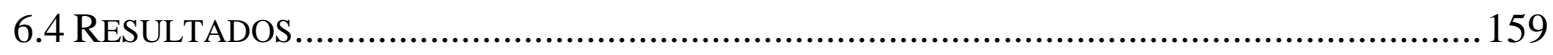


6.4.1 Ofertas atual e potencial de áreas para ingressarem no mercado de compensação de $R L$ por doação de área de UC de domínio público: uma análise dos parques nacionais (Parnas) do bioma Cerrado e suas áreas sem cadastros 159

6.4.2 Ofertas atual e potencial de áreas para ingressarem no mercado de compensação de RL por doação de área de UC de domínio público: uma análise das estações ecológicas (EEs) do bioma Cerrado e suas áreas sem cadastros. 164

6.4.3 Ofertas atual e potencial de áreas para ingressarem no mercado de compensação de RL por doação de área de UC de domínio público: uma análise das reservas extrativistas (Resex) do bioma Cerrado e suas áreas sem cadastros 168

6.4.4 Ofertas atual e potencial de áreas para ingressarem no mercado de compensação de RL por doação de área de UC de domínio público: análise das florestas nacionais (Flonas) do bioma Cerrado e suas áreas sem cadastros 172

6.4.5 Ofertas atual e potencial de áreas para ingressarem no mercado de compensação de $R L$ por doação de área de UC de domínio público: uma análise das reservas biológicas (Rebios) do bioma Cerrado e suas áreas sem cadastros 175

6.5 As UCS DE DOMÍNIO PÚBLICO DO CERRADO: ANÁLISE DOS INDICADORES TOTAIS E SEUS PERCENTUAIS DAS OFERTAS ATUAIS E POTENCIAIS DE TERRAS PARA O MERCADO DE COMPENSAÇÃO DE RL POR DOAÇÃO DE ÁREA DE UC E DAS ÁREAS SEM CADASTROS DESTAS UCs 


\section{INTRODUÇÃO}

A criação e implementação de áreas protegidas é um dos principais instrumentos para a conservação da biodiversidade e de valores culturais associados, assim como para o uso sustentável dos recursos naturais (ARAÚJO; BARRETO, 2015). O presente estudo tem como objeto a análise de dois destes espaços ambientalmente protegidos ${ }^{1}$ : as Unidades de Conservação (UCs) de domínio público e as Reservas Legais (RLs). Desde o ano de 2012, com a promulgação do Novo Código Florestal (NCF), criou-se um mecanismo que possibilita uma relação entre ambas as áreas, ou seja, elas fazem parte de um mesmo processo que contribui para dois objetivos diferentes: a regularização ambiental da RL em propriedades privadas e a regularização fundiária das UCs de domínio público.

Esse mecanismo é denominado de compensação de RL mediante doação ao poder público de área localizada no interior de UC de domínio público pendente de regularização fundiária. Ou seja, refere-se à possibilidade legal dada a um produtor rural, que desmatou sua RL antes de 2008, de sanar esse déficit mediante a compra de uma outra área, de um proprietário rural pendente de regularização fundiária, no interior de uma UC para, posteriormente, doar essa área ao poder público (BRASIL, 2012).

A regularização ambiental da RL e a regularização fundiária das UCs são dois temas de profunda importância: o primeiro deles refere-se ao significativo passivo de RL nas propriedades rurais privadas. Esse passivo de RL, em decorrência do não cumprimento da legislação, foi estimado em 11,3 milhões de hectares (ha) (GUIDOTTI et al., 2017) e decorre de um processo histórico de descumprimento das obrigações de manutenção da RL, por parte dos proprietários rurais, num cenário de avanço do agronegócio e de dificuldades do Estado de fazer cumprir os instrumentos de comando e controle.

O outro ponto intrinsicamente relacionado à compensação de RL em UC, e não menos importante, refere-se ao passivo fundiário dentro das UCs de domínio público que foram criadas, mas que não tiveram suas áreas regularizadas mediante desapropriação e indenizações aos proprietários privados que possuem terras em seu interior. $\mathrm{O}$ passivo estimado para a desapropriação de áreas privadas dentro de UCs federais é de aproximadamente 5,4 milhões ha

\footnotetext{
${ }^{1}$ Os espaços territoriais especialmente protegidos, no Brasil, compreendem as UCs definidas na Lei $\mathrm{n}^{\circ}$ 9.985, de 18 de julho de 2000, que institui o Sistema Nacional de Unidades de Conservação (SNUC), bem como as áreas de preservação permanente (APPs) e RLs, estabelecidas pelo Código Florestal (Lei no 12.651). Além dessas, o Plano Estratégico Nacional de Áreas Protegidas (Decreto $n^{\circ}$ 5.758, de 13 de abril de 2006) inclui as terras indígenas e terras ocupadas por remanescentes das comunidades dos quilombos no rol dos espaços territoriais especialmente protegidos (PELLIN et al., 2007).
} 
(TCU, 2013). Segundo o Plano de Regularização das Unidades de Conservação, elaborado pelo Instituto Chico Mendes de Conservação da Biodiversidade (ICMBio), no ano de 2012, o Brasil tinha 312 UCs, um mosaico de riqueza natural que envolve praticamente $10 \%$ de todo o território nacional, somando 75,1 milhões ha. Desse total, segundo o relatório do ICMBio (2012), 16,9 milhões ha são de propriedades privadas. Na média, isso significa que, de cada 100 metros quadrados de floresta protegida, 23 metros quadrados são ocupados por propriedades privadas.

Este cenário, em que há a permanência de propriedades privadas no interior de UCs de domínio público, é indesejável, pois inviabiliza que estas áreas protegidas cumpram com os objetivos para os quais foram criadas (SARETTA, 2017; OLIVEIRA, 2010; TCU, 2013).

O problema da regularização fundiária não parece factível de ser solucionado no curto e médio prazo, considerando que os recursos orçamentários alocados para essa atividade pelo Estado são ínfimos e que não existe vontade política dos governantes em realizar a regularização fundiária das UCs, ou seja, a mudança de domínio do privado para a instituição pública responsável pela sua gestão (ROCHA; DRUMMOND; GANEM, 2010). Somente a partir da mudança deste domínio de áreas (do privado para o público) que as UCs de domínio público terão suas áreas consolidadas territorialmente.

O NCF, instituído com a Lei $\mathrm{n}^{\mathrm{o}} 12.651$ no ano de 2012, estabelece uma política de criação de um mercado para as áreas privadas inseridas no interior das UCs de domínio público, sendo uma contribuição para a regularização fundiária das UCs de domínio público por viabilizar a compra destas áreas (que estavam à espera de desapropriação pelo Estado) por proprietários que desmataram suas RLs e demandam essas terras para poderem compensar o déficit de RL de seus imóveis rurais.

Saretta (2017) realizou análise ambiental, econômica e jurídica do mecanismo de compensação de RL por doação de área em UCs de domínio público por meio de entrevistas com os principais atores envolvidos nesse assunto. Eles apontam esse mecanismo como a grande inovação do NCF, por proporcionar, sem ônus financeiros ao Estado, a regularização fundiária das UCs de domínio público, auxiliando na política de consolidação territorial dessas UCs. Contudo existem diversos conflitos fundiários no interior das áreas de UCs que impedem esse mercado de operar, por exemplo: 1) áreas particulares inseridas nos limites das UCs e sobrepostas a áreas públicas, assentamentos ou terras indígenas; 2) sobreposição de áreas privadas entre si, que possuem alguma irregularidade em seus registros e/ou cadastros; 3 ) existência de áreas sem dominialidade, que não estão apossadas, nem cadastradas e registradas, as ditas terras devolutas; 4) áreas que foram apossadas de terras devolutas; 5) áreas cujos títulos 
de propriedade e demais documentos relacionados ao domínio particular de terras são falsificados; 6) existência questionável de áreas onde as terras foram apossadas, que poderão ou não constituir propriedades privadas.

Esses conflitos fundiários foram instaurados historicamente no Brasil e são resultados da insegurança da propriedade das terras brasileiras em todos os domínios (públicas, privadas, terras indígenas, quilombolas etc.) (REYDON et al., 2017).

Diante da debilidade da governança fundiária brasileira, relacionada aos direitos de propriedade da terra, a presente tese tem como problemática a análise e o alcance desta política de compensação de RL por doação de área em UCs como mecanismo para se atingir o objetivo proposto de criação de um mercado de terras das UCs de domínio público, mediante o mecanismo de compensação de RL.

Nesse sentido, a pergunta que norteou este trabalho foi a seguinte: diante da debilidade da governança fundiária brasileira, qual o alcance da política de criação de mercado para compensar a área dos imóveis rurais sem RL por áreas tituladas privadas inseridas nos limites das UCs de domínio público instituída pelo NCF (Lei nº 12.651 no ano de 2012) no bioma Cerrado?

Nesses termos, trabalha-se com a hipótese de que sejam poucas as áreas aptas para serem ofertadas no mercado de terras, situação decorrente dos conflitos fundiários da maioria das terras inseridas nos limites das UCs de domínio público. Argumenta-se que o mercado de compensação de RL não será efetivado de forma ampla, como solução ambiental para fomentar a consolidação territorial das UCs de domínio público, em decorrência dos conflitos fundiários que necessitam de solução.

O objetivo da presente tese é contribuir com essa discussão ao sistematizar uma metodologia que permite aferir a área atual, inserida nas UCs de domínio público do bioma Cerrado, que podem ser transacionadas nesse mercado.

Para se atingir esse objetivo e confirmar essa hipótese, o presente trabalho tem como referencial teórico os conceitos e princípios da política ambiental (e seus instrumentos de política) e da governança de terras. O principal elemento discutido nessa literatura é o importante papel das instituições que regem os direitos de propriedade para o bom desempenho da política ambiental e de uma boa governança fundiária na criação e operacionalização dos mercados de terras.

As análises discutidas em diversos trabalhos acadêmicos sobre esses temas trazem elementos teóricos para se traçar uma reflexão sobre a política instituída pelo NCF e o seu 
mecanismo de compensação de RL por doação de área de UCs de domínio público à luz da governança de terras formada historicamente no Brasil.

Esta tese está organizada em cinco capítulos, além desta introdução e das considerações finais.

No capítulo 2, analisa-se o Código Florestal como política ambiental, iniciando uma discussão teórica sobre a política ambiental e seus instrumentos (comando e controle, instrumentos econômicos e de comunicação) e sua combinação de instrumentos formando uma policymix. Esse capítulo se encerra com a discussão do NCF como política ambiental, em que existe a combinação e a utilização dos instrumentos de regulação direta, instrumentos econômicos e de comunicação, utilizados de forma conjunta (policymix), construída por meio de arranjos institucionais mais sofisticados. Em especial, analisa-se o instrumento de criação do mercado de compensação de RL por doação de áreas em UCs de domínio público.

O entendimento desta política ambiental, de compensação de RL por doação de área das UCs de domínio público, demanda uma análise mais aprofundada do NCF, no sentido de situálo num contexto mais amplo como uma política que é regida pelos princípios constitucionais e tem um desenvolvimento histórico permeado de conflitos e embates entre seus principais atores: os ambientalistas, os produtores rurais e o governo.

O terceiro capítulo desta tese dedica-se a uma discussão sobre os princípios constitucionais dos espaços ambientalmente protegidos por lei, o direito de propriedade e sua função social e o modo como o NCF regulamentou historicamente as áreas de RL e suas formas de compensação. Nesse contexto, discute-se com maior ênfase a compensação de RL por doação de área em UCs de domínio público.

A política ambiental instituída pelo NCF, que promove um mercado de terras para as áreas privadas inseridas nas UCs de domínio público mediante a compensação de RL, será operacionalizada no contexto da débil governança de terras brasileira. Esse é o tema do quarto capítulo, que discute o conceito e os princípios de governança e administração de terras, de acordo com os princípios e diretrizes preconizados pela Food and Agriculture Organization, em português, Organização das Nações Unidas para a Alimentação e a Agricultura (FAO, 2007). Esses temas serão narrados nesse capítulo, para posteriormente serem analisados à luz da governança fundiária do Brasil. O item 4.4 e os subsequentes descrevem o sistema de administração de terras do Brasil, em especial, o sistema de cadastro e o de registro de terras.

A problemática da consolidação territorial das UCs de domínio público, que ocorre por meio da regularização fundiária destas UCs, será discutida no capítulo 5 deste estudo. 
As terras que foram destinadas para serem áreas de UCs de domínio público foram estabelecidas tendo como contexto histórico a débil governança de terras brasileiras, que tem como característica os conflitos fundiários mencionados anteriormente.

No processo de criação das UCs, que são espaços territoriais especialmente protegidos, a eficácia da proteção a ser buscada está na escolha da categoria de proteção adotada na área, ou seja, na categoria de manejo que é escolhida no momento de sua criação com o ente responsável pela execução e gestão dessas áreas. Assim, o ato da criação das UCs de domínio público já pressupõe a necessidade da regularização fundiária, processo necessário para fazer com que a área que integra a UC esteja na posse e domínio de quem é de direito, para que esse ente responsável execute sua gestão, seu plano de manejo.

Em outras palavras, para que as UCs de domínio público sejam efetivas e cumpram com os objetivos para os quais foram criadas, é essencial que se efetive a transferência de domínio das terras das UCs para o ente responsável por meio da regularização fundiária, que é um processo de construção de políticas públicas com o auxílio de instrumentos jurídicos vigentes.

A ênfase desse capítulo é para a regularização fundiária das UCs de domínio público, dada sua importância para a integralização do território e para a gestão de suas áreas.

Ainda no capítulo 5, destaca-se a fragilidade das normas e leis referentes ao ato de criação das UCs, que somente foi normatizada com a Instrução Normativa (IN) $n^{\circ} 5$, de 15 de maio de 2008, editada pelo ICMBio. Somente com essa norma que foi regulamentada a realização de estudos técnicos, entre estes, estudos fundiários, que seriam objetos para as regularizações fundiárias posteriores.

No mesmo sentido, as normas processuais para a regularização fundiária das UCs, entre estas, o procedimento para avaliação e indenização dos imóveis e benfeitorias, somente foram regulamentadas na IN do ICMBio $\mathrm{n}^{\circ} 2$, de 3 de setembro de 2009, tanto para as UCs preexistentes como para as UCs criadas na vigência do Sistema Nacional de Unidades de Conservação (SNUC), no ano de 2002.

Ao considerar a débil governança de terras do Brasil e a carência de normas para proceder à criação e à regularização das terras das UCs, a situação fundiária das UCs de domínio público reflete e é parte do caos fundiário instalado historicamente no país. Pode-se afirmar que praticamente todas as UCs do Brasil possuem algum tipo de irregularidade que traz conflitos fundiários que são de difícil solução (ROCHA; DRUMMOND; GANEM, 2010), dada a situação da governança de terras do país.

Para ilustrar esses conflitos e o montante de áreas para serem ofertadas no mercado de compensação de RL por doação de área de UC de domínio público, o capítulo 6 dedica-se à 
metodologia utilizada e aos principais resultados sobre a situação das UCs de domínio público do bioma Cerrado brasileiro.

A escolha do bioma Cerrado (item 6.2) foi guiada por critérios ambientais e econômicos. De acordo com a pesquisa bibliográfica, nota-se que as características da ocupação do Cerrado (grandes propriedades monocultoras, o acelerado avanço da fronteira agrícola e, consequentemente, o aumento do preço da terra) tornam a compensação dessas áreas pelo mecanismo da doação de área em UC de domínio público bastante atrativa economicamente, dado que o custo de oportunidade da alternativa (de restaurar as áreas de RL deficitárias) é alto por mantê-las com vegetação já que o valor da produção agropecuária no imóvel rural é elevado. Assim, a compensação de RL por doação de área em UC de domínio público é um instrumento viável, uma vez que há a possibilidade de continuar utilizando a área produtiva na propriedade com um elevado custo de oportunidade, ante o baixo preço da terra nas UCs de domínio público.

Para a análise desta tese, serão contabilizadas a oferta atual e a oferta potencial de áreas (em hectares) (até março de 2018) de 63 UCs de domínio público pendentes de regularização fundiária no bioma Cerrado ${ }^{2}$. Essas informações serão provenientes das seguintes fontes de dados: 1) propriedades e posses rurais autodeclaradas no Cadastro Ambiental Rural (CAR) e 2) áreas particulares certificadas no Sistema de Gestão Fundiária (Sigef) pelo Instituto Nacional de Colonização e Reforma Agrária (Incra), que são aquelas que possuem matrícula registrada no Cartório de Registro de Imóveis, dessa forma, são propriedades rurais que podem ser ofertadas no mercado de compensação de RL analisado. Também colaboram com esses indicadores tanto as informações do Cadastro Nacional de Unidades de Conservação (CNUC) relacionadas à situação fundiária de cada UC de domínio público do Cerrado - ou seja, se estas estão totalmente, parcialmente ou não regularizadas - como as informações sobre a existência ou não de ocupações nas áreas das UCs. Vale acrescentar que o CNUC não possui informações fundiárias e de ocupação para todas as UCs do Cerrado, ficando um montante considerável de UCs sem constar destas informações.

As áreas particulares cadastradas (no interior das UCs de domínio público) no Sigef e certificadas pelo Incra são aquelas que realmente estão aptas para serem ofertadas no mercado de compensação de RL por doação de área de UC. Contudo essas áreas possuem sobreposição de áreas entre si e com demais tipos de terras, como as áreas certificadas públicas no Sigef, as terras indígenas e os assentamentos.

\footnotetext{
${ }^{2}$ Não estão contabilizadas neste levantamento as UCs municipais.
} 
O item 6.3 apresenta mais detalhadamente como e o que foi realizado para se chegar no cálculo das ofertas atual e potencial de terras, que são respectivamente as áreas particulares certificadas no Sigef e as áreas cadastradas no CAR, ambas sem sobreposição com áreas de outros domínios (como as terras públicas, assentamentos e terras indígenas).

Para identificação das UCs que possuem em seu interior áreas particulares, terras indígenas e outras terras públicas, gerando algum conflito fundiário e litígios, utilizou-se as camadas de dados individuais no formato shapefile dos limites de UCs do bioma Cerrado, das terras indígenas, dos assentamentos rurais e os dados de imóveis rurais disponíveis no CAR e no Sigef. As camadas de dados foram processadas individualmente e depois sobrepostas no ambiente de Sistema de Informações Geográficas (SIG). Os itens subsequentes do item 6.3 explicam esse processamento de dados.

Após a discussão sobre a metodologia utilizada neste trabalho, o item 6.4 traz os principais resultados dos indicadores de oferta atual de terras (áreas particulares certificadas no Sigef sem sobreposição de áreas de outros domínios) e áreas de oferta potencial (áreas cadastradas no CAR sem sobreposição de áreas de outros domínios) e áreas sem cadastros nessas UCs. Esses indicadores foram analisados por categoria de UC de domínio público, ou seja, parques nacionais, estações ecológicas, reservas extrativistas, florestas nacionais e reservas biológicas.

O item 6.5 dedica-se à análise dos indicadores totais das ofertas atuais e potenciais de terras para o mercado de compensação de RL por doação de área de UC e as áreas sem cadastro dessas UCs.

O último capítulo deste trabalho dedica-se às conclusões. 


\section{INSTRUMENTOS DA POLÍTICA AMBIENTAL}

O presente capítulo tem como objetivo trazer os conceitos teóricos da política ambiental e seus instrumentos como subsídios para a análise do NCF, que é a principal política ambiental que rege as áreas florestais em propriedades privadas e que organiza o instrumento de compensação de RL por doação de áreas das UCs de domínio público.

Desde a sua criação, o Código Florestal é o principal regramento brasileiro destinado à proteção da vegetação natural existente nas propriedades rurais (Sparovek et al., 2010), o que representa 329 milhões de hectares distribuídos ao largo de todo o território rural do país (IBGE, 2007) (SILVA; MARQUES; SAMBUICHI, 2016, p. 11).

Para tanto, o item 2.1 deste capítulo situa as políticas ambientais no Brasil e no mundo ao longo da história, as fases desta política e seu desenvolvimento ao longo do tempo. O item 2.2 traz uma análise e descrição dos instrumentos de políticas, são eles: comando e controle, instrumentos econômicos e de comunicação.

O item 2.3 traz o conceito de policymix, que é a utilização dos instrumentos de regulação direta, instrumentos econômicos e de comunicação, apresentados de forma conjunta, ainda que não necessariamente todos devam estar presentes numa mesma política.

A discussão teórica sobre o conceito e aplicação da política ambiental e seus instrumentos formando uma policymix foram os parâmetros e referenciais de análise da política ambiental do NCF (Lei no 12.651, de 2012), analisado no item 2.4 deste capítulo.

\subsection{Histórico da política ambiental no mundo e no Brasil}

As políticas ambientais foram sendo criadas e aprimoradas em consonância das evoluções de conceitos e disputas políticas ao longo das décadas. Para Lustosa, Cánepa e Young (2010), é possível separar a evolução da política ambiental, a partir de seus instrumentos, em três fases, variando o tempo e frequência de aplicação de cada de acordo com cada país.

A primeira fase estendeu-se desde o fim do século XIX até o período anterior à Segunda Guerra Mundial e teve como forma preferencial de intervenção estatal a disputa em tribunais, onde as vítimas das externalidades negativas ambientais entravam em juízo contra os agentes poluidores e devastadores. A disputa em tribunais tornou-se excessivamente custosa, não somente em termos financeiros, mas também em tempo de resolução de litígios (LUSTOSA; CÁNEPA; YOUNG, 2010). 
Houve uma passagem gradual e progressiva para a segunda fase, iniciada aproximadamente na década de 1950. O setor público impôs tanto padrões de emissão incidentes sobre a produção final, ou sobre o nível de utilização de um insumo básico do agente poluidor, como também determinou a melhor tecnologia disponível para o abatimento da poluição e cumprimento do padrão de emissão (LUSTOSA; CÁNEPA; YOUNG, 2010).

Em decorrência das críticas apontadas pelas políticas de comando e controle, inicia-se uma iniciativa por parte dos que elaboram e fazem política (policymakers) de incentivar os comportamentos dos agentes econômicos para a internalização dos custos ambientais. Assim, os padrões de emissão etc. deixaram de ser meio e fim da política ambiental, passando a ser utilizados com instrumentos econômicos.

Desde a primeira fase da política ambiental, os fatos históricos e as políticas mundiais desencadearam um processo de estruturação institucional e de formulação de políticas ambientais nos diferentes países.

Pode-se afirmar que foram quatro eventos que definiram a trajetória da política ambiental no mundo. O primeiro foi a promulgação da política ambiental americana, em 1969, que estabeleceu as ligações entre o processo de decisão e as preocupações com a qualidade ambiental, introduzindo importantes instrumentos administrativos, como o Ato de Declaração de Impactos Ambientais (Environmental Impact Statement - EIS), também conhecido como Estudo de Impacto Ambiental (EIA), e o estabelecimento do Conselho da Qualidade Ambiental, órgão diretamente ligado ao poder executivo, em que o Estado assume, em nome da coletividade, a efetiva administração do ambiente como bem público, mantendo os cidadãos informados pela sua qualidade (LUSTOSA; CÁNEPA; YOUNG, 2010; MAGRINI, 2001).

O segundo evento foi a realização da Conferência das Nações Unidas em Estocolmo, em 1972, onde, pela primeira vez, os países industrializados do Ocidente sentiram necessidade de refletir e discutir problemas ligados à questão ambiental. Nesse mesmo ano, Dennis Meadows e alguns outros pesquisadores publicaram o estudo Limites do Crescimento, importante documento que introduziu o debate na comunidade intelectual voltada ao questionamento do modo de desenvolvimento perseguido pelas nações (MAGRINI, 2001).

O terceiro evento que definiu a trajetória da política ambiental foi o trabalho realizado pela Comissão Mundial sobre Meio Ambiente e Desenvolvimento que resultou na publicação do relatório Nosso Futuro Comum (em 1987) e, finalmente, a realização da Conferência das Nações Unidas no Rio de Janeiro, em 1992 (MAGRINI, 2001).

Foi no contexto da Tese do Clube de Roma, da Conferência de Estocolmo e da publicação do relatório Nosso Futuro Comum, popularmente chamado de Relatório de 
Brundtland, que surgiu, em 1987, a proposta de um novo modelo de desenvolvimento que deveria necessariamente levar em conta a preservação ambiental e, ao mesmo tempo, permitir o crescimento dos países. Surgiu assim o conceito de ecodesenvolvimento dos países, fundamentado no crescimento econômico com bases na equidade social, cultural e ambiental.

Foi Ignacy Sachs que formulou os princípios básicos dessa nova visão de desenvolvimento, apoiado na proposta do canadense Maurice Strong, em 1973. São seis as diretrizes das políticas de desenvolvimento que os países deveriam seguir:

[...] a) a satisfação das necessidades básicas; b) a solidariedade com as futuras gerações; c) a participação da população envolvida; d) a preservação dos recursos naturais e do meio ambiente em geral; e) elaboração de um sistema social garantindo emprego, segurança social e respeito a outras culturas, e f) programas de educação (BRÜSEKE, 1998, p. 31).

O ecodesenvolvimento e o conceito de desenvolvimento sustentável - elaborado no Relatório de Brundtland como aquele que "atende às necessidades do presente sem comprometer a possibilidade de as gerações futuras atenderem as suas próprias necessidades" (COMISSÃO..., 1988, p. 46) - conformaram um objetivo a ser alcançado pela política ambiental dos países e seus instrumentos ao longo das décadas.

No Brasil, após a Conferência de Estocolmo, em 1972, o processo de institucionalização de políticas e da gestão ambiental experimentou avanços consideráveis, guardadas suas especificidades econômicas, políticas e culturais (MAGRINI, 2010). Segundo Lustosa, Cánepa e Young (2010), até a década de 1970, não existia um órgão especificamente voltado ao controle ambiental. As legislações existentes tratavam da exploração de alguns recursos naturais por meio de medidas isoladas:

Código Florestal de 1934 (Decreto $\mathrm{n}^{\circ} 23.793$ ), tratava da questão das matas nativas, sendo posteriormente reformado pela Lei $\mathrm{n}^{\circ} 4.771$, de 1965 .

Código das Águas de 1934 (Decreto ${ }^{\circ}$ 24.643), estabelecia normas de uso dos recursos hídricos, com especial atenção ao seu aproveitamento hidrelétrico.

Comissão da Defesa da Borracha de 1947 (Lei $n^{\circ}$ 86), estabelecia medidas que visavam à assistência econômica da borracha natural, reestrutura posteriormente em 1967.

Superintendência do Desenvolvimento da Pesca (SUDENE) de 1962 (Lei delegada $\mathrm{n}^{\circ} 10$ ), vinculada ao Ministério da Agricultura (LUSTOSA; CÁNEPA; YOUNG, 2010, p. 173).

Sob recomendação da Conferência das Nações Unidas sobre o Meio Ambiente, criouse a Secretaria Especial do Meio Ambiente (Sema) (Decreto ${ }^{\circ}$ 73.030), vinculada ao Ministério do Interior (LUSTOSA; CÁNEPA; YOUNG, 2010).

Embora leis e normas tenham sido criados na década de 1970, apenas em 1981 é que a Lei n 6.938 estabeleceu os objetivos, as ações e os instrumentos da Política Nacional do Meio 
Ambiente. Esta lei instituiu a Política e o Sistema Nacional do Meio Ambiente, contando com importantes instrumentos que são até hoje aplicados no Brasil ${ }^{3}$.

Do ponto de vista institucional, desde a promulgação da Lei $n^{\circ}$ 6.938/81, foram essencialmente mantidas as atribuições em nível federal, estadual e municipal. Por meio de leis e decretos, foram modificadas algumas figuras da estrutura original, dentre as quais destacamse: em 1989, a fundação do Instituto Brasileiro do Meio Ambiente e dos Recursos Naturais Renováveis (Ibama) a partir de outras instituições e do Comitê do Fundo Nacional do Meio Ambiente e, em 1992, a criação do Ministério do Meio Ambiente, cujas denominação e composição foram modificadas diversas vezes nesses anos.

A Política Nacional do Meio Ambiente, de 1981, também deu origem ao Conselho Nacional de Meio Ambiente (Conama) e ao Sistema Nacional de Meio Ambiente (Sisnama); a Lei da Ação Civil Pública - Lei no 7.347/85, a Política Nacional de Recursos Hídricos, de 1997, a Lei de Crimes Ambientais de 1998, a Política Nacional de Educação Ambiental , de 1999, a Lei do SNUC, de 2000, o Estatuto das Cidades, de 2001, a Lei de Resíduos Sólidos, sancionada em 2010.

Todos esses sistemas nacionais de gestão ambiental que se originaram da política nacional de 1981, ao longo das décadas de 1980 e 1990, seguiram as diretrizes do capítulo de meio ambiente criado pela Constituinte de 1988, que introduziu princípios descentralizantes e democráticos de gestão e, em sua articulação com a legislação anterior, permitiu a ampliação da ação de movimentos sociais e organizações não governamentais (ONGs). Somente em 1997 foi promulgada a regulamentação federal sobre licenciamento ambiental (Resolução Conama $\left.n^{\circ} 237 / 97\right)$.

Segundo Campos (2017, p. 30),

[...] o modelo de gestão ambiental brasileiro possui diversas fragilidades decorrentes da própria constituição e características de seu Estado. São elas: a ausência histórica de prioridade política da questão ambiental no Brasil; o nítido descompasso entre a existência de um corpo legal avançado e a frágil implementação prática dessas leis; a falta de integração e de coordenação entre as políticas setoriais que impactam o meio ambiente, como as políticas relacionadas à energia, aos transportes, à agropecuária, ao extrativismo, à industrialização e à mineração; a própria ambiguidade da ação do Estado que, por um lado, estimula e promove o crescimento econômico e a degradação dos recursos naturais e, por outro lado, tenta administrar o controle da degradação produzida.

\footnotetext{
${ }^{3}$ Os instrumentos são: Padrões de Qualidade Ambiental; Zoneamento Ambiental (posteriormente denominado Zoneamento Ecológico Econômico); Avaliação de Impactos Ambientais; Licenciamento e revisão de atividades efetiva ou potencialmente poluidoras; Sistema Nacional de Informações Ambientais (MAGRINI, 2010; LUSTOSA; CÁNEPA; YOUNG, 2010).
} 
Estas características, da fragilidade do modelo de gestão ambiental brasileiro, citadas por Campos (2017) também são encontradas na governança de terras do Brasil, tema que será tratado no capítulo 4 deste documento.

\subsection{Instrumentos de política ambiental}

Os instrumentos no âmbito das políticas públicas são ferramentas utilizadas para atingir os objetivos definidos para uma dada política (MOTTA, 2000, 2014; MOTTA; RUITENBEEK; HUBER, 1996). Uma política ambiental deve ter fundamentação teórica, metas e instrumentos e também prever penalidades para aqueles que não cumprirem as normas estabelecidas.

Nesse sentido, a política ambiental pode ser definida como o conjunto de metas, instrumentos e políticas que pretendem reduzir os impactos ambientais da ação humana sobre o meio ambiente. Dessa forma, ela interfere nas atividades dos agentes econômicos, portanto a maneira pela qual é estabelecida influencia as demais políticas públicas (LUSTOSA; CÁNEPA; YOUNG, 2010).

O objetivo da política ambiental é induzir ou forçar os agentes econômicos a adotarem posturas e procedimentos que degradem menos ou recuperem o meio ambiente (LUSTOSA; CÁNEPA; YOUNG, 2010). Os meios adotados pelo poder público para o cumprimento da política ambiental em prol de seus objetivos são denominados de instrumentos de política ambiental. Cada instrumento possui suas características e objetivos de atuação.

As categorias mais usadas na literatura (RING; SCHROTER-SCHLAACK, 2011 apud CAMPOS, 2017; LUSTOSA; CÁNEPA; YOUNG, 2010) dividem-se em três tipos: instrumentos de regulação direta (regulatórios ou de comando e controle), instrumentos econômicos (ou baseados em incentivos) e instrumentos de comunicação.

\subsubsection{Instrumentos de comando e controle}

Os instrumentos de comando e controle também são conhecidos como de regulação direta, pois determinam uma intervenção direta sobre a ação ambiental dos agentes econômicos e o controle direto sobre os locais que estão emitindo os poluentes. Essas são medidas institucionais que buscam influenciar a ação dos agentes pela regulação direta e impositiva, ou seja, implicam o controle direto por parte dos órgãos reguladores por meio de normas, controles, procedimentos, regras e padrões a serem seguidos e também diversas punições caso os agentes não cumpram as regras estabelecidas (LUSTOSA; CÁNEPA; YOUNG, 2010, p. 169). 
Segundo Schröter, Schlaack e Blumentrath (2011 apud CAMPOS, 2017) existem três tipos básicos de instrumentos reguladores relacionados à biodiversidade e, portanto, à prestação de serviços ecossistêmicos: 1) regulamentação via tecnologia (envolve a regulamentação da gestão e da produção de recursos, tais como as normas técnicas (por exemplo, a melhor técnica disponível na produção); 2) prescrição de boas práticas; 3) restrições à utilização de produtos.

O segundo tipo, a regulamentação por desempenho, envolve a regulamentação de regras consideradas sustentáveis socialmente, como normas de emissão ou normas de qualidade ambiental (SCHRÖTER; SCHLAACK; BLUMENTRATH, 2011 apud CAMPOS, 2017).

O terceiro tipo envolve o ordenamento do território e busca coordenar as várias atividades existentes em uma determinada área a partir da delimitação dos usos e ocupações, em níveis diferentes de restrições, em uma dada região (SCHRÖTER; SCHLAACK; BLUMENTRATH, 2011 apud CAMPOS, 2017).

As políticas de comando e controle, para serem eficientes, requerem que os direitos de propriedade ligados a um recurso ambiental estejam bem estabelecidos, por exemplo, os direitos de uso dos proprietários de terras, as práticas de manejo a serem cumpridas pelos agricultores ou a exigência de compensação por impactos ambientais. Se o direito de propriedade não estiver definido claramente, essa política ambiental terá problemas para a sua operacionalização (SCHRÖTER; SCHLAACK; BLUMENTRATH, 2011 apud CAMPOS, 2017).

Segundo os mesmos autores, esses instrumentos têm sido percebidos como altamente efetivos para a conservação ambiental por diversos motivos. São eles: 1) pelo seu poder de polícia, já que, em um período curto de tempo, pode-se interromper uma ação que esteja degradando o ambiente como também implementar ações ambientalmente corretas por meio de padrões mínimos de conservação; 2) esses instrumentos podem ser mais facilmente adaptados para considerarem condições locais (regras de zoneamento dependendo das aptidões do solo) ou diferentes padrões que afetam diferentes áreas de emissão; 3) a efetividade de um padrão independe dos custos de oportunidade percebidos (CAMPOS, 2017; MOTTA; RUITENBEEK; HUBER, 1996).

Segundo Andrade e Borges (2011), os instrumentos de comando e controle podem ser realmente eficazes no controle dos impactos ambientais, porém possuem uma desvantagem, já que tratam todos os agentes poluidores da mesma forma, desconsiderando suas características e diferenças, tais como porte e quantidade de poluentes emitidos. Assim, esses instrumentos apresentam desvantagem por falhar em promover a alocação de recursos eficiente e não prover incentivos a empresas que se mantêm abaixo das metas. Atualmente, caso um limite de emissões de poluentes seja fixado em uma quantidade que certa empresa ainda não ultrapassou, 
ela poderá chegar até esse limite caso sua produção aumente, já que não possui nenhum incentivo para manter níveis mais baixos de poluição (DALY; FARLEY, 2010).

Uma outra crítica à regulamentação direta é que os agentes econômicos ficam com pouca margem de manobra, tendo como consequência uma alta resistência política para estabelecer padrões rígidos que possam causar altos custos de conformidade (SCHRÖTER; SCHLAACK; BLUMENTRATH, 2011 apud CAMPOS, 2017).

O contexto institucional em que são formuladas as políticas de comando e controle é de extrema importância para o sucesso destes instrumentos. Os papéis relacionados à regulação e ao poder de polícia dos governos precisam funcionar em associação para o cumprimento das normas estabelecidas, significando altos custos de implementação, de manutenção e com maiores custos administrativos (MOTTA; RUITENBEEK; HUBER, 1996).

\subsubsection{Instrumentos econômicos}

Os instrumentos econômicos, ou instrumentos de mercado, procuram internalizar os custos ambientais nas atividades econômicas para influenciar os agentes responsáveis pelo dano ambiental a modificarem o padrão de uso dos recursos naturais. Assim, o objetivo desses instrumentos é incentivar os agentes econômicos a considerarem os custos sociais nas suas decisões individuais, afetando o cálculo de seus custos e benefícios, influenciando suas decisões e contribuindo para a melhoria na qualidade ambiental (MOTTA; RUITENBEEK; HUBER, 1996).

A degradação ambiental (externalidade), ao ser internalizada por meio dos instrumentos econômicos, passa a fazer parte da planilha de custo da empresa, que pode decidir pelos custos de poluir ou de controlar a poluição (MOTTA; RUITENBEEK; HUBER, 1996).

Motta, Ruitenbeek e Huber (1996) conceituam o incentivo econômico como todo mecanismo de mercado que oriente os agentes econômicos a valorizarem os bens e serviços ecossistêmicos de acordo com sua escassez e seu custo de oportunidade social. O elemento essencial da definição de instrumentos econômicos é, portanto, o seu caráter de indutor dos comportamentos desejados pela política ambiental, por meio de uma ação oposta à dos instrumentos de comando e controle, que operam com a obrigação (NUSDEO, 2012, p. 101).

Segundo Motta (2014), os instrumentos econômicos podem ser adotados para alcançar três objetivos: 1) indução de comportamento de agentes econômicos, coibindo comportamentos indesejados pela política e incentivando a adoção daqueles desejados; 2) correção de preços para incluir o custo das externalidades negativas; 3) geração de receitas. Os instrumentos 
econômicos têm como vantagem a geração de receitas fiscais e tarifárias para garantir receitas aos órgãos ambientais, considerando os diferentes custos de controle entre os agentes econômicos, diferentemente dos de regulação direta, que são custosos financeiramente para o setor público (LUSTOSA; CÁNEPA; YOUNG, 2010).

Os instrumentos econômicos podem ser classificados como precificados e de criação de mercado. No tocante aos instrumentos econômicos precificados, dois princípios destacam-se como base para a sua aplicação: o poluidor pagador e o usuário pagador, que conferem direitos que permitem a internalização de custos que não seriam normalmente internalizados pelo poluidor ou usuário (“externalidades”) (MOTTA, 2000, p. 88; NUSDEO, 2012, p. 101).

Os instrumentos de criação de mercado estabelecem direitos transacionáveis entre agentes ou negociação em mercado aberto, como tem ocorrido com os créditos de carbono. Para Motta (2014), outra forma de trabalhar com instrumentos que fomentam alteração de comportamento é com a criação de mercados de direito de uso. Se a primeira estratégia, a dos instrumentos precificados, atua no preço do recurso natural, esta segunda atua sobre a quantidade total do recurso. Este mecanismo aloca direitos de uso do recurso aos usuários e permite-lhes que transacionem entre si estes direitos de uso. Servidão ambiental e mercado de carbono são exemplos de mercados de direitos de uso. O mercado é o regulador que coloca o preço no direito transacionado com base na disponibilidade total do recurso (MOTTA, 2014).

Nos mercados são distribuídos ou vendidos como direitos de uso ou poluição que nos padrões de referências utilizados não ultrapassem os níveis de uso ou de poluição desejados. Uma vez realizada esta alocação inicial, níveis de uso ou de poluição acima das cotas individuais teriam que ser obtidos por transações destes direitos entre os usuários/poluidores. Por exemplo, o usuário/poluidor que tiver um custo alto de controle terá um incentivo para comprar cotas daqueles com custos menores (MOTTA, 2000).

De acordo com Motta (2000), é a ausência de (ou dificuldade de assinalar) direitos completos de propriedade dos recursos ambientais que torna seu uso menos eficiente. Caso a especificação dos direitos completos seja possível, uma negociação entre os usuários poderia ocorrer de forma que os usos de maior retorno (mais eficiente) seriam priorizados, ou seja, as trocas de direitos no mercado induziriam os usuários de maior benefício de uso (ou menor custo) a pagar mais por esses direitos. Os termos da negociação teriam como base os custos e benefícios percebidos pelas partes.

Orientando o uso de instrumentos econômicos para a questão ambiental, a primeira condicionante é a consolidação e codificação da legislação ambiental e a criação do espaço legal para a adoção desses instrumentos (MOTTA, 2000). A introdução gradual do instrumento 
econômico deve ser planejada para testar os resultados simulados e da modelagem, assim como os arranjos institucionais.

Para definir o arranjo institucional das opções de instrumento econômico, há que se identificar o papel e as obrigações de cada organização e os incentivos para a cooperação. Observe-se que a receita do instrumento econômico constitui, muitas vezes, um bom incentivo para a cooperação, mas os benefícios secundários advindos da aplicação bem-sucedida do instrumento, por exemplo, a redução nos gastos públicos e o crescimento setorial, podem ser também atraentes. Os reguladores devem achar meios de confirmar a capacidade de cada instituição envolvida, criando as conexões formais necessárias (MOTTA, 2000).

Assim sendo, essas experiências podem não ser uma resposta imediata para os países onde tal contexto não é observado. Quando os custos administrativos são altos e demandam mais capacidade institucional do que aquela de que se dispõe, um instrumento econômico pode enfrentar as mesmas limitações institucionais que aquelas identificadas para os instrumentos orientados para o controle (MOTTA, 2000).

Os reguladores devem também atentar para os aspectos legais da opção do uso do instrumento econômico que podem afetar os direitos de propriedade convencionais, podendo exigir, por conseguinte, um novo arcabouço legal difícil de se estabelecer. Assim, as opções finais têm que estar de acordo com esses aspectos legais para evitar um longo processo de legalização ou disputas judiciais futuras. Em alguns casos, a aplicação do instrumento econômico resulta em necessidades orçamentárias adicionais, em vez de gerar receita extra, conforme esperado (MOTTA, 2000).

A capacidade institucional tem que ser totalmente avaliada para cada opção de instrumento, levando em conta parcerias com outros órgãos governamentais ou privados que possam ser afetadas pelo instrumento econômico ou que possam ser de interesse na implementação deste (MOTTA, 2000).

As críticas à adoção de instrumentos de mercado podem ser divididas em duas ordens: inadequação aos fins ambientais almejados e incapacidade de garantir resultados equitativos nas relações entre grupos sociais, setores econômicos e mesmo na relação entre países (NUSDEO, 2012).

\subsubsection{Instrumentos de comunicação}

De acordo com Lustosa, Cánepa e Young (2010, p. 170): 
[...] os instrumentos de comunicação são utilizados para conscientizar e informar os agentes poluidores e as populações atingidas sobre diversos temas ambientais, como os danos ambientais causados, atitudes preventivas, mercados de produtos ambientais, tecnologias menos agressivas ao meio ambiente, e facilitar a cooperação entre os agentes poluidores para buscar soluções ambientais. São exemplos de instrumentos de comunicação: a educação ambiental, a divulgação de benefícios par as empresas que respeitem o meio ambiente e os selos ambientais.

Esses instrumentos de comunicação visam a promover alterações de preferências e comportamentos individuais e coletivos para informar ou educar pessoas sobre a relação entre suas atividades e o ambiente por meio de valores morais e cívicos do indivíduo ou de instituições, no sentido de interromper um comportamento que degrada o ambiente (LUSTOSA; YOUNG, 2002).

Os instrumentos de comunicação também são importantes como forma de compartilhar informações sobre temas ambientais para construir confiança, credibilidade, parcerias e cooperação entre organizações e suas partes interessadas. O compartilhamento das informações tem como objetivos conscientizar os envolvidos na utilização destas para o processo decisório, facilitando motivações intrínsecas para autorregulação na conservação da biodiversidade ou de manejo de serviços ecossistêmicos (SCHRÖTER-SCHLAAC, 2011 apud CAMPOS, 2017).

A comunicação é um fator importante para proteger os recursos naturais, principalmente devido às graves assimetrias de informações que existem na ausência de intervenção (por exemplo, entre regulador e regulado, entre grandes e pequenas empresas, entre a comunidade e as empresas e entre compradores e fornecedores). A falta de confiabilidade é uma lacuna existente neste tipo de instrumento que é baseado na informação, pois não há garantia de que a informação por si só conduzirá à obtenção de resultados ambientais predeterminados ou quantificáveis (GUNNINGNHAM; SINCLAIR, 1999 apud CAMPOS, 2017).

A prestação de informações é um fator crucial para praticamente todos os outros instrumentos, já que os agentes dependem de informações suficientes para tomar decisões (GUNNINGNHAM; SINCLAIR, 1999 apud CAMPOS, 2017).

\subsection{Policymix ou policy mix}

Como existe uma série de relações nas questões e problemas ambientais, sugere-se a combinação e utilização dos instrumentos de regulação direta, instrumentos econômicos e de comunicação. Utilizados de forma conjunta, mas não necessariamente, todos os instrumentos podem fazer parte de uma mesma política. 
À combinação dos diversos instrumentos de política construída por meio de arranjos institucionais mais sofisticados com o objetivo de influenciar quantitativa e qualitativamente a conservação da biodiversidade, deu-se o nome de policy mix ou policymix 4 . O termo é definido como uma combinação de instrumentos de política que, dada a complexidade da questão ambiental, foi evoluindo na composição das políticas para influenciar a conservação da biodiversidade e a provisão de serviços ecossistêmicos pelos setores públicos e privados (RING; SCHRÖTER-SCHLAACK, 2011 apud CAMPOS, 2017).

Para se desenvolver um mix de instrumentos de política que seja eficaz ambiental e economicamente, como já dito, deve-se fazer uma análise do problema ambiental que será tratado.

A biodiversidade e os ecossistemas proveem bens e serviços com valores múltiplos que, em sua maioria, são intangíveis (benefícios como regulação climática) e possuem características de bens públicos (não rivais e não excludentes). Principalmente este último aspecto, segundo a literatura, exige a adoção de mix de instrumentos de política, uma vez que, por um lado, valores de uso diretos, quando se tratam de serviços de abastecimento, apropriados pela iniciativa privada, em muitos casos são corrigidos por instrumentos econômicos. Em contrapartida, os valores de uso indiretos, por exemplo, os serviços de regulação e os valores de não uso, necessitam de instrumentos de política mais coercitivos, regulamentadores, sendo então necessário implementar esses dois tipos de instrumentos de política ambiental (RING; SCHRÖTER-SCHLAACK, 2011 apud CAMPOS, 2017).

Andrade e Borges (2011, p. 9-13) citam a existência de pelo menos cinco problemas que podem, em tese, justificar a utilização de policymix: i) direitos de propriedade imperfeitos e outras externalidades; ii) múltiplas externalidades; iii) poder de mercado e externalidades; iv) comportamentos não observáveis; v) informações imperfeitas e externalidade.

Num ambiente em que existem as falhas de mercado, como as incertezas e as diferenças entre os proprietários e usuários de propriedade relacionados à terra ou aos recursos específicos, ou devido à natureza de bem público de vários aspectos da biodiversidade, sugere-se a utilização de mais de um instrumento de política. Apenas um mix de instrumentos de política consegue abranger os interesses e os objetivos para se alcançar a proteção da biodiversidade. Nesse sentido, devem ser considerados os vários atores existentes, como o público, o privado e as ONGs (CAMPOS, 2017).

\footnotetext{
${ }^{4}$ Policymix é um termo que foi criado por volta dos anos 1960, por Jan Tinbergen, inicialmente para ilustrar em modelagem macroeconômica que, para atingir vários objetivos definidos, são necessários vários instrumentos de políticas (TINBERGEN, 1956 apud BERNASCONI, 2013).
} 
Em uma política que possui um conjunto de instrumentos e diversos atores atuando para se alcançar diversos objetivos, são necessários diferentes níveis de coordenação intra e interinstitucional. Também é importante que haja coordenação entre as políticas ambientais e as outras políticas afins. Ademais, o contexto institucional pode comprometer o sucesso dos instrumentos de política ambiental, como no caso de subsídios adversos no setor de agricultura, pesca, infraestrutura etc. (CAMPOS, 2017).

Para Schröter-Schlaack e Blumentrath (2011 apud CAMPOS, 2017), existe um escopo considerável de possibilidades de usar instrumentos regulatórios em etapas posteriores da formulação de um mix de políticas. Porém, uma estrutura regulatória com requisitos fundamentais, como direitos de propriedade garantidos e assegurados, constitui uma precondição básica para a introdução de outros instrumentos, como esquemas de direitos negociáveis, pagamentos por serviços ambientais (PSAs) ou taxas ambientais.

As circunstâncias econômicas, ecológicas, sociais e políticas a serem consideradas de forma sistêmica nas políticas são tão complexas que não há ainda definição de um ótimo de instrumentos e mecanismos. Nesse sentido, um grupo de pesquisadores de nove instituições de oito países se uniu para desenvolver o projeto POLICYMIX ${ }^{5}$ para analisar, mediante estudos de caso com seis países, a combinação dos instrumentos de políticas para conservação. O objetivo do projeto, com duração entre 2010 e 2014, foi alterar o foco de análise de políticas ambientais do "custo-efetividade de instrumentos individuais" para um entendimento de como os instrumentos interagem uns com os outros (BERNASCONI, 2013).

Segundo Bernasconi (2013), as análises desenvolvidas nesse projeto concluíram que os instrumentos econômicos não são uma alternativa aos de comando e controle ou aos instrumentos de informação, mas, sim, dependentes e complementares entre si.

\subsubsection{Os instrumentos de policymix na política ambiental do NCF (Lei $n^{o} 12.651$ de 2012)}

A política desenhada pelo NCF (Lei n 12.651, de 2012), para a compensação de RLs mediante doação de área de UC de domínio público para seu órgão gestor, pode ser analisada como uma política que utiliza instrumentos de forma conjunta (policymix) e também na abordagem das políticas denominadas cap-and-trade. Nestas, primeiramente, é definido um limite quantitativo de uso de um recurso, de emissões de gases etc., para garantir a escala. No

\footnotetext{
${ }^{5}$ O Projeto POLICYMIX é apoiado por recursos da Comissão Europeia, Diretoria Geral para Pesquisa, dentro do Programa Quadro 7 do RTD, Tema 2 - Biotecnologia, Agricultura e Alimentos (Doação no 244.065) (BERNASCONI, 2013).
} 
caso das políticas de compensação de RL por doação, em vez de ser definido um limite de uso de um recurso ou emissão, é definido um limite de obrigação de conservação. Dessa forma, nesta política, o que deve ser distribuído de forma justa não são os direitos de uso, e sim os deveres de conservação. Estes deveres de conservação são definidos pela legislação brasileira que atribui que a RL, ou seja, as áreas cobertas por vegetação natural para fins de conservação dos recursos naturais, de acordo com os diferentes biomas brasileiros, deva ter as proporções de $80 \%$ do total da propriedade para a áreas de Floresta Amazônica, 35\% para as áreas de Cerrado e $20 \%$ para as demais regiões do Brasil. Caso essas exigências impostas pela lei não sejam obedecidas pelos proprietários de terras, o Estado, teoricamente, pode, com seus instrumentos de comando e controle, fiscalizar, multar e penalizar o proprietário infrator da legislação.

Os deveres de conservação foram distribuídos, porém não respeitados, pelos detentores dos imóveis rurais, tema que será discutido no capítulo 4 deste trabalho. Neste contexto de desobediência da lei por parte dos proprietários, o NCF instituiu um mecanismo que permitiu a criação de um mercado de terras em que as áreas nas UCs de domínio público que precisam ser regularizadas, ou seja, que precisam passar do domínio privado para o público, sejam ofertadas para os detentores de imóveis rurais que estão com déficit de RL em seus imóveis, já que eles são os demandantes que precisam sanar este déficit por meio da compra de áreas privadas que precisam ser regularizadas. Desse mercado, somente podem participar aqueles demandantes de áreas que retiraram suas RLs antes da data de 22 de julho de 2008, ou seja, antes da data de promulgação da Lei de Crimes Ambientais (Lei nº 9.605).

As áreas de UC de domínio público, ao serem decretadas como áreas de preservação, são proibidas por lei de terem qualquer atividade econômica incompatível com seus critérios de conservação ambiental. Consequentemente, elas também deixam de ter valor monetário, sendo retiradas do mercado de terras, restando aos proprietários ou posseiros dessas terras somente a desapropriação por parte do Estado.

Assim, o Estado, ao fomentar este mecanismo de compensação de RL por doação de área de UC de domínio público, cria um mercado de terras em que os ofertantes são os proprietários de terras com áreas inseridas nas UCs e os demandantes são os proprietários de terras com déficit de RL. O preço de transação dessas áreas será formado pelo mercado de acordo com os custos de oportunidade da terra, preço, custos de transação, fatores culturais etc.

O mecanismo de criação de mercado de compensação de RL por doação de áreas de UC de domínio público atribui valor econômico às áreas de vegetação nativa protegidas por lei, ao mesmo tempo que, na teoria, possibilita a regularização fundiária das UCs sem o grande ônus 
financeiro para os cofres públicos que ocorre com as desapropriações. Um outro aspecto que favorece o poder público, para além do não pagamento pelas desapropriações de terras aos proprietários com áreas inseridas nos perímetros das UCs, é que a compensação de RL por doação propicia uma considerável economia de recursos humanos, já que o poder público não precisa realizar o levantamento de documentos e tampouco a avaliação do imóvel, refletindo numa economia de diárias e tempo de seus servidores públicos.

Outro aspecto que o mecanismo de compensação de RL por doação de UC de domínio público soluciona que também se refere às desapropriações de terras é a definição de valores desses imóveis, que é sempre um processo longo e que, na maioria dos casos, por falta de consenso entre as partes, traz a necessidade de recorrer ao sistema judiciário.

Os proprietários de terras no interior das UCs têm um incentivo para providenciarem a documentação e os processos pendentes de suas áreas, por exemplo, problemas com inventários, falta de pagamento do Imposto sobre a Propriedade Territorial Rural (ITR) e/ou solicitação de isenção do ITR com retroatividade ao Ministério da Fazenda. Enfim, esses proprietários irão providenciar todos os documentos relacionados à titularidade da terra para que esta seja transacionada.

A política ambiental instituída pelo NCF coincide com a teoria no sentido de implementar instrumentos econômicos que geram receitas e economia de custos de atividades que seriam de responsabilidade do setor público, ao mesmo tempo que atinge vários objetivos da política ambiental, como a regularização fundiária das UCs e a regularização ambiental das RLs.

Como exposto anteriormente, o NCF foi elaborado por meio das combinações dos instrumentos econômicos ${ }^{6}$ com os de comando e controle, formando a política de criação de

\footnotetext{
${ }^{6}$ Vale destacar que o NCF institui outras formas de compensação de RL e diversos instrumentos econômicos para fomentar a preservação e a recuperação da vegetação nativa e para promover o desenvolvimento de atividades produtivas sustentáveis. O Capítulo $\mathrm{X}$, "Do programa de apoio e incentivo à preservação e à recuperação do meio ambiente" (arts. 41 a 50), contempla a criação de programa de incentivos econômicos financeiros e fiscais (art. 41) e a instituição de Cotas de Reserva Ambiental ou CRAs (arts. 44 a 50). O art. 41 autoriza a instituição pelo Executivo Federal do "programa de apoio e incentivo à conservação do meio ambiente, bem como para adoção de tecnologias e boas práticas que conciliem a produtividade agropecuária e florestal, com redução dos impactos ambientais, como forma de promoção do desenvolvimento ecologicamente sustentável, observados sempre os critérios de progressividade". Três categorias são previstas: (i) Pagamento ou incentivo a serviços ambientais relacionados com o carbono, a beleza cênica, a biodiversidade, a água, o clima, o solo, a valorização cultural e o conhecimento tradicional ecossistêmico, as Áreas de Preservação Permanente (APPs), as RLs e áreas de uso restrito; (ii) Compensação por medidas de conservação ambiental por meio de instrumentos como a obtenção de crédito e seguro agrícolas, a redução do ITR para as APPs e RL, a destinação de parte dos recursos oriundos da cobrança pelo uso da água, a criação de linhas de financiamento alinhadas a esse objetivo e a isenção de impostos; (iii) Incentivos associados ao uso sustentável da floresta, como a participação preferencial em programas de apoio à comercialização da produção agrícola e a destinação de recursos para a pesquisa científica.
} 
um mercado de terras para as áreas de UCs de domínio público que, ao mesmo tempo, seja um instrumento de compensação de RLs.

O Código Florestal também apresenta seu instrumento de comunicação para trabalhar com as políticas de instrumentos econômicos e de regulação direta (comando e controle) de forma sinérgica. O instrumento de comunicação desta política é o Sistema Nacional de Cadastro Ambiental Rural (Sicar) ${ }^{7}$, que é o sistema eletrônico de âmbito nacional destinado ao gerenciamento de informações ambientais dos imóveis rurais regulamentado pelo Decreto $\mathrm{n}^{\circ}$ 7.830, de 17 de outubro de 2012 (BRASIL, 2012).

O CAR é um dos instrumentos mais importantes na nova sistemática prevista no Código Florestal. Isso porque é a partir dele que todos os dados relativos às propriedades e posses rurais, em especial sobre as Áreas de Preservação Permanente (APP) e RLs, poderão ser analisados na orientação tanto para a implementação dos demais instrumentos do NCF como para o planejamento e monitoramento das políticas públicas no âmbito rural. O CAR, no processo de regularização ambiental, é um instrumento obrigatório para a obtenção de crédito agrícola, para as transações acerca das Cotas de Reserva Ambiental (CRA), para a obtenção de possíveis pagamentos por serviços ambientais/ecossistêmicos e etc. Nesse sentido, o CAR é um instrumento de comunicação indispensável para o funcionamento da nova Lei Florestal.

No entanto, este instrumento de comunicação possui fragilidades. A insegurança da propriedade privada no Brasil, por exemplo, é um fator que o fragiliza como sinalizador do mercado de terras da compensação de RL por doação de área das UCs. O entendimento desta problemática relacionada com a insegurança da propriedade da terra remete-se à análise da governança de terras brasileiras e seus instrumentos de administração fundiária, entre estes, o registo e o cadastro de terras.

Resumidamente pode-se afirmar que desde a Lei de Terras de 1850, quando se fundou o mercado de terras no Brasil, foram criados cadastros muito frágeis quanto à definição da propriedade, tendo em vista que esta, até os dias atuais, não é realizada com exatidão em relação à identificação da parcela cadastrada. Assim, os registros de direitos foram concebidos sobre propriedades indefinidas quanto às suas características físicas e de localização geográfica, o

\footnotetext{
${ }^{7}$ O Sicar e o CAR serão analisados no capítulo 4. O Decreto n 7.838 , de 17 de outubro de 2017, dispõe que o Sicar foi instituído com o objetivo de: I - receber, gerenciar e integrar os dados do CAR de todos os entes federativos; II - cadastrar e controlar as informações dos imóveis rurais, referentes a seu perímetro e localização, aos remanescentes de vegetação nativa, às áreas de interesse social, às áreas de utilidade pública, às APPs, às Áreas de uso restrito, às áreas consolidadas e às RLs; III - monitorar a manutenção, a recomposição, a regeneração, a compensação e a supressão da vegetação nativa e da cobertura vegetal nas APPs, de uso restrito e de RL, no interior dos imóveis rurais; IV - promover o planejamento ambiental e econômico do uso do solo e conservação ambiental no território nacional; V - disponibilizar informações de natureza pública sobre a regularização ambiental dos imóveis rurais em território nacional na Internet (BRASIL, 2012).
} 
que não traz a garantia do direito sobre a propriedade descrita na matrícula (REYDON, 2007). Outros fatores que foram criados historicamente e que contribuíram para que o Brasil tenha uma governança de terras frágil serão discutidos no capítulo subsequente.

De acordo com a teoria do sistema de administração de terras, os direitos de propriedade somente são definidos quando estes dois procedimentos, o registro e o cadastro, estão unificados, o que não ocorre no Brasil. Isso explica muito da fragilidade histórica nacional sobre os direitos de propriedade da terra, abrindo espaço a inúmeros conflitos e fraudes com terras (REYDON; BUENO; SIQUEIRA, 2017).

A Lei ${ }^{\circ} 10.267$ de 2011 criou o Cadastro Nacional de Imóveis Rurais (CNIR), em construção até os dias atuais, que determinou a obrigatoriedade de atualização do cadastro sempre que houver alteração nos imóveis rurais, o georreferenciamento de acordo com o Sistema Geodésico Brasileiro e, ainda, o intercâmbio mensal de informações entre os serviços do Cartório de Registro de Imóveis e o Incra, promovendo uma integração entre o registro e o cadastro. A ferramenta utilizada para alcançar a certificação dos imóveis é o Sigef, o qual será tratado no capítulo 4.

Soma-se aos fatos relacionados à fragilidade dos cadastros de terras no Brasil o caráter autodeclaratório das informações existentes nos cadastros do Brasil. Entre os muitos problemas decorrentes da autodeclaração, está a sobreposição de áreas, com exceção do CNIR (por integrar o sistema de cadastros ao de registro de imóveis).

As inconsistências do CAR como um cadastro ambiental que não se comunica com o cadastro fundiário são estruturais e decorrentes da débil governança e administração de terras no Brasil. Esse tema será discutido no capítulo 4. O CAR, ao se configurar somente para fins ambientais, sem comunicação com o cadastro fundiário, informa as áreas autocadastradas pelos proprietários privados dentro dos limites das UCs de domínio público. Estas áreas formam uma oferta potencial de terras para o mercado de compensação de RL por doação de área de UC de domínio público, já que muitas não possuem o título de propriedade, são posses, possuem sobreposição com outras áreas autodeclaradas elou são objetos de diversas formas de fraudes.

Este é um dos pontos fundamentais para se entender a fragilidade do CAR como instrumento de comunicação para o funcionamento do mercado de terras das UCs de domínio público para se efetivar a compensação de RL por doação de área de UC. Porém, vale ressaltar a importância do CAR como instrumento de preservação e conservação dos recursos naturais inseridos nos imóveis rurais.

Antes de adentrar na análise da governança de terras do Brasil, é necessário dissertar sobre o conceito de RL e a contextualização da criação do mercado de terras em UCs de domínio 
público, tendo como ênfase o instrumento de compensação de RL ao longo da história das promulgações dos códigos florestais. Este tema será tratado no próximo capítulo. 


\section{O NOVO CÓDIGO FLORESTAL: AS RESERVAS LEGAIS NAS PROPRIEDADES PRIVADAS E SUA COMPENSAÇÃO POR DOAÇÃO DE ÁREA NAS UNIDADES DE CONSERVAÇÃO}

A Constituição Federal de 1988 estabeleceu uma série de atribuições específicas voltadas ao poder público e privado, dentre as quais está a manutenção dos espaços territoriais especialmente protegidos, que são áreas legalmente estabelecidas em terras de domínio público ou privado dedicadas à manutenção dos recursos naturais, manejadas mediante uso e ocupação para atingir os objetivos da conservação e recuperação dos recursos naturais. Entre estas áreas, estão as UCs de domínio público, que, em tese, teriam suas áreas em propriedade do Estado (federal, estadual ou municipal), e as RLs e as APPs, situadas no interior das propriedades privadas. O item 3.1 trata sobre esse tema.

A manutenção de espaços territoriais especialmente protegidos está alicerçada na Constituição de 1988 por meio de princípios relacionados ao meio ambiente ecologicamente equilibrado, para o qual a propriedade privada deve cumprir sua função social, como afirma o art. $5^{\circ}$, incisos XXII e XXIII. Dessa forma, a função social da propriedade e a defesa do meio ambiente formam os princípios da ordem econômica, como bem destaca o art. 170, incisos II, III e VI da Constituição de 1988, que serão abordados no item 3.2.

Estes princípios e diretrizes, que são estabelecidos no texto constitucional brasileiro para os espaços territoriais especialmente protegidos, são regulados pelo SNUC por meio da Lei $n^{\circ}$ 9.985, de julho de 2000, e pelo NCF (Lei nº 12.651, de 2012). Neste capítulo, somente será dissertado sobre o $\mathrm{NCF}^{8}$, que é o principal marco legal para conservação dos recursos naturais em áreas privadas, na medida em que dispõe sobre as áreas de RL e APPs disciplinando suas regras e diretrizes de aplicação, tema tratado no item 3.2.1.

No Brasil, as áreas de RL e as APPs são tão importantes para a proteção dos ecossistemas como a das UCs (SILVA, 2012). O Brasil tem 65\% do seu território (566 milhões de hectares) coberto por vegetação natural, dos quais 302 milhões de hectares (53\%) estão localizados em terras privadas e 264 milhões de hectares (47\%), em áreas de conservação pública (FREITAS; SPAROVEK; MATSUMOTO, 2016, p. 132). Segundo o MMAICNUC (2017), as áreas de UCs correspondem a 154,4 milhões de hectares, representando $18,1 \%$ do território brasileiro 9 .

\footnotetext{
${ }^{8}$ O SNUC será discutido no capítulo 5 deste documento.

${ }^{9}$ Outros estudos sobre o uso e a cobertura da terra demostram que aproximadamente 194 milhões de hectares de vegetações nativas estão protegidas na forma de APPs e RL (SOARES-FILHO et al., 2014).
} 
Os produtores rurais, desde a criação das RLs e das APPs, em 1934, até o NCF, promulgado em 2012, não cumpriram efetivamente com as suas obrigações de manutenção da RL e das APPs em seus imóveis rurais. Conforme aponta Cunha (2013), as regras do NCF, principalmente as referentes à RL e às APPs, sempre foram ignoradas pelo setor produtivo rural, repercutindo num enorme passivo ambiental. Os diagnósticos realizados demonstram um passivo da ordem de 83 milhões de hectares de áreas de preservação ocupadas irregularmente, de acordo com a legislação ambiental antes do NCF (SILVA, 2012, p. 10). Para Sparovek et al. (2010), estimava-se a existência de, pelo menos, 85 milhões de hectares de passivos de APPs e RLs nas propriedades rurais.

Diante deste cenário de não cumprimento da manutenção da RL e de APPs nas propriedades privadas, ao longo dos anos, os conflitos e as negociações políticas entre os diversos atores envolvidos nesse tema (principalmente entre ruralistas, ambientalistas e o governo) foram encaminhadas no sentido da compensação da RL, dada a incapacidade econômica de sua restauração, ou seja, os custos e os benefícios nela implicados (SPAROVEK et al., 2011).

O item 3.3 traz uma análise sobre o instrumento de compensação de RL por doação ao poder público de área localizada no interior de UC de domínio público pendente de regularização fundiária. No item 3.4, é narrado o histórico da compensação de RL, que se iniciou com a Medida Provisória (MP) $n^{\circ}$ 1.511/96, percorrendo caminhos de embates e negociações até chegar no texto final do NCF (Lei n $\left.{ }^{\circ} 12.651 / 2012\right)$.

A compensação de RL por doação de área em UC de domínio público e outras regras e mecanismos adotados pelo NCF propiciam um padrão de proteção ambiental inferior ao anteriormente existente (CAMPOS, 2017). Foi estimado que, com o NCF, a necessidade de restauração ambiental foi reduzida de 50 milhões de hectares para 21 milhões de hectares (SOARES-FILHO et al., 2014; FREITAS; SPAROVEK; MATSUMOTO, 2016, p. 125).

A nova lei (NCF) implicou a anistia das multas e sanções decorrentes de desmatamento ilegais realizados antes da promulgação da Lei de Crimes Ambientais, que foi em 22 de julho de 2008, na isenção e no tratamento diferenciado a pequenas propriedades rurais, na inclusão das APPs no cômputo das áreas de RL e no mecanismo de compensação de RL. Esses temas são objeto de Ações Diretas de Inconstitucionalidade (ADIs) atualmente em curso no Supremo Tribunal Federal (STF) - caso das ADIs nº 4.901, 4.902, 4.903 e 4.937. O presente capítulo se encerra com o item 3.5, que narra brevemente as polêmicas geradas pelo Código Florestal, ajuizadas nessas quatro ADIs. 


\subsection{Os espaços ambientalmente protegidos: as Unidades de Conservação de domínio público e as áreas de florestas privadas tituladas de Reserva Legal}

A Constituição Federal de 1988, ao versar sobre o meio ambiente, traz no caput do artigo 225 uma norma-princípio enunciativa do direito de todos ao meio ambiente ecologicamente equilibrado:

Art. 225. Todos têm direito ao meio ambiente ecologicamente equilibrado, bem de uso comum do povo e essencial à sadia qualidade de vida, impondose ao Poder Público e à coletividade o dever de defendê-lo e preservá-lo para as presentes e futuras gerações (BRASIL,1988).

O texto constitucional de 1988 estabeleceu uma série de atribuições específicas voltadas ao poder público e privado. Dentre elas, insere-se a instituição dos espaços territoriais especialmente protegidos e sua preservação para as gerações presentes e futuras. Estes espaços territoriais especialmente protegidos são públicos ou privados e são criados pelo poder público com o objetivo de proteção especial ao meio ambiente. Pereira e Scardua (2008) enquadram esse conceito como gênero que abarca 16 espécies de espaços protegidos:

1) as unidades de conservação;

2) as áreas destinadas às comunidades tradicionais;

3) as áreas tombadas;

4) os monumentos arqueológicos e pré-históricos;

5) as áreas especiais e locais de interesse turístico, destinados à prática do ecoturismo;

6) as reservas da biosfera;

7) os corredores ecológicos;

8) as zonas de amortecimento;

9) os espaços protegidos constitucionalmente como patrimônio nacional, a Floresta Amazônica, a Mata Atlântica, a Serra do Mar, a Zona Costeira e o Pantanal Mato-Grossense;

10) as áreas de proteção especial, destinadas à gestão ambiental urbana;

11) os jardins botânicos;

12) os hortos florestais;

13) os jardins zoológicos;

14) as terras devolutas e arrecadadas, necessárias à proteção dos ecossistemas naturais;

15) os megaespaços ambientais, protegidos também pelas seguintes normas internacionais: a Convenção das Nações Unidas sobre o Direito do Mar, o Tratado da Bacia do Prata, o Tratado de Cooperação Amazônica, a Convenção Relativa a Zonas Úmidas de 
Importância Internacional e a Convenção Relativa à Proteção do Patrimônio Mundial Cultural e Natural;

16) por fim, as áreas de preservação permanente e as reservas legais, previstas no Código Florestal.

As áreas apontadas anteriormente, como visto, constituem exemplos de espaços territoriais especialmente protegidos de caráter obrigatório, que devem ter sua manutenção garantida tanto pelos proprietários das terras onde elas se encontram como pelo Estado. As florestas de domínio privado, assim como as florestas de domínio público, possuem regras que organizam sua exploração, sendo que muitas destas são de preservação integral.

Os espaços ambientalmente protegidos, que são objeto desta tese, são as UCs de domínio público e as áreas das florestas privadas tituladas de RL, que, no NCF, abrangem também as APPs. Ambos possuem como finalidade comum a garantia de um meio ambiente ecologicamente equilibrado, porém são espaços bastante distintos entre si e que não se confundem.

O capítulo 5 deste estudo dissertará sobre a situação fundiária das UCs de domínio público e sua consolidação territorial mediante as regularizações fundiárias das propriedades privadas inseridas em seus limites. Este capítulo restringe-se à análise das florestas privadas, em especial da RL situada nos imóveis rurais.

\subsection{Propriedade privada, sua função social e o NCF}

O atual sistema constitucional conjuga, por assim dizer, o direito ao meio ambiente ecologicamente equilibrado às garantias do direito de propriedade, sendo que esta deve cumprir sua função social. Esses direitos estão inseridos no art. $5^{\circ}$, incisos XXII e XXIII:

Art. $5^{\circ}$ Todos são iguais perante a lei, sem distinção de qualquer natureza, garantindo-se aos brasileiros e aos estrangeiros residentes no País a inviolabilidade do direito à vida, à liberdade, à igualdade, à segurança e à propriedade, nos termos seguintes: [...]

XXII - é garantido o direito de propriedade;

XXIII - a propriedade atenderá a sua função social (BRASIL, 1988).

A função social da propriedade possui três elementos essenciais: o econômico (exploração produtiva do imóvel rural), social (distribuição da riqueza produzida e promoção de bem-estar e dignidade) e ambiental (conservação dos recursos naturais).

$\mathrm{O}$ art. 186 e seus incisos especificam que a função social da propriedade rural deverá atender simultaneamente a quatro requisitos: "I - aproveitamento racional e adequado; II utilização adequada dos recursos naturais disponíveis e preservação do meio ambiente; III - 
observância das disposições que regulam as relações de trabalho; IV - exploração que favoreça o bem-estar dos proprietários e dos trabalhadores" (BRASIL, 1988).

Assim também, quando trata da ordem econômica e elege seus princípios, destaca a propriedade privada e, sucessivamente, sua função social e a defesa do meio ambiente como princípios da ordem econômica (art. 170, inc. II, III e VI):

Art. 170 - A ordem econômica, fundada na valorização do trabalho e na livre iniciativa, tem por fim assegurar a todos a existência digna, conforme os ditames da justiça social, observados os seguintes princípios: [...]

II - propriedade privada;

III - função social da propriedade; [...]

VI - defesa do meio ambiente (BRASIL, 1988).

Essas normas constitucionais impõem aos particulares determinadas limitações quanto ao uso e ao trato com o meio ambiente na propriedade privada. A utilização dessas propriedades deve dar-se dentro das condições que assegurem a preservação ambiental.

O NCF, seguindo os preceitos da Constituição de 1988, estabelece no caput do art. $2^{\circ}$ que:

Art. $2^{\circ}$ As florestas existentes no território nacional e as demais formas de vegetação nativa, reconhecidas de utilidade às terras que revestem, são bens de interesse comum a todos os habitantes do País, exercendo-se os direitos de propriedade com as limitações que a legislação em geral e especialmente esta Lei estabelecem (BRASIL, 2012).

A RL configura-se como uma limitação imposta à propriedade rural e é entendida como:

Art. $3^{\circ}[\ldots]$ III - área localizada no interior de uma propriedade ou posse rural, delimitada nos termos do art. 12, com a função de assegurar o uso econômico de modo sustentável dos recursos naturais do imóvel rural, auxiliar a conservação e a reabilitação dos processos ecológicos e promover a conservação da biodiversidade, bem como o abrigo e a proteção de fauna silvestre e da flora nativa (BRASIL, 2012).

A conservação da RL é uma exigência da legislação brasileira para toda e qualquer propriedade ou posse rural, devendo ser conservada pelo proprietário do imóvel rural, possuidor ou ocupante a qualquer título, pessoa física ou jurídica de direito público ou privado, com vegetação nativa. Essas obrigações, de acordo com o artigo 66, parágrafo $1^{\circ}$ do NCF, são transmitidas ao sucessor nos casos de transferência de domínio ou posse do imóvel (BRASIL, 2012).

Essa exigência legal de conservar uma parcela da área no interior das propriedades se embasa na ideia de que ela representa componente essencial para a conservação da biodiversidade no país. Nesse sentido, a criação de espaços naturais especialmente protegidos em áreas de domínio privado é considerada a principal estratégia de contenção às crescentes ameaças à manutenção da biodiversidade. 


\subsubsection{A Reserva Legal no NCF: regras e diretrizes}

A RL pode ser entendida como uma parte percentual de cada imóvel rural que a legislação impõe que permaneça com cobertura vegetal, ou para servir de reserva de mata, com o propósito de assegurar o uso sustentável dos recursos naturais e a preservação da biodiversidade. Nos termos do NCF, a localização da RL deverá ser estabelecida pelo órgão ambiental competente, ou seja, o proprietário poderá indicar a área, mas ela deverá ser aprovada pelo órgão em questão (CAMPOS, 2017).

Definida a reserva legal no art. $3^{\circ}$ do NCF, o capítulo IV vem estabelecer os parâmetros para a determinação de sua área e localização, bem como alguns casos de dispensa. Destaca-se que o tratamento da RL não se esgota nesse capítulo, existindo referências a ele em outros capítulos do NCF.

A área destinada à RL é calculada com base em porcentagem sobre a área total do imóvel rural, que varia de acordo com a localização da propriedade e do bioma existente no local, da seguinte forma:

Art. 12. Todo imóvel rural deve manter área com cobertura de vegetação nativa, a título de Reserva Legal, sem prejuízo da aplicação das normas sobre as Áreas de Preservação Permanente, observados os seguintes percentuais mínimos em relação à área do imóvel, excetuados os casos previstos no art. 68 desta Lei: (Redação dada pela Lei n 12.727 , de 2012).

I - localizado na Amazônia Legal:

a) $80 \%$ (oitenta por cento), no imóvel situado em área de florestas;

b) $35 \%$ (trinta e cinco por cento), no imóvel situado em área de Cerrado;

c) $20 \%$ (vinte por cento), no imóvel situado em área de campos gerais;

II - localizado nas demais regiões do País: $20 \%$ (vinte por cento) (BRASIL, 2012).

De acordo com o art. 12, $\S 1^{\circ}$, independentemente do fracionamento do imóvel, a RL deverá manter a mesma área anteriormente calculada. Essa medida tem como propósito evitar que a divisão do imóvel altere a composição da área de RL e eventuais desvirtuamentos em relação ao tratamento diferenciado dispensado à pequena propriedade.

O NCF prevê alguns casos de redução do percentual da RL localizada na Amazônia Legal:

$\S 4^{\circ}$ Nos casos da alínea a do inciso I, o poder público poderá reduzir a Reserva Legal para até $50 \%$ (cinquenta por cento), para fins de recomposição, quando o Município tiver mais de 50\% (cinquenta por cento) da área ocupada por unidades de conservação da natureza de domínio público e por terras indígenas homologadas.

$\S 5^{\circ}$ Nos casos da alínea a do inciso I, o poder público estadual, ouvido o Conselho Estadual de Meio Ambiente, poderá reduzir a Reserva Legal para 
até $50 \%$ (cinquenta por cento), quando o Estado tiver Zoneamento EcológicoEconômico aprovado e mais de 65\% (sessenta e cinco por cento) do seu território ocupado por unidades de conservação da natureza de domínio público, devidamente regularizadas, e por terras indígenas homologadas (BRASIL, 2012).

Os parágrafos seguintes, do art. 12 do NCF, tratam das hipóteses de dispensa da RL:

$\S 6^{\circ}$ Os empreendimentos de abastecimento público de água e tratamento de esgoto não estão sujeitos à constituição de Reserva Legal.

$\S 7^{\circ}$ Não será exigido Reserva Legal relativa às áreas adquiridas ou desapropriadas por detentor de concessão, permissão ou autorização para exploração de potencial de energia hidráulica, nas quais funcionem empreendimentos de geração de energia elétrica, subestações ou sejam instaladas linhas de transmissão e de distribuição de energia elétrica.

$\S 8^{\circ}$ Não será exigido Reserva Legal relativa às áreas adquiridas ou desapropriadas com o objetivo de implantação e ampliação de capacidade de rodovias e ferrovias (BRASIL, 2012).

O poder público federal poderá ainda ampliar as áreas de RL em até $50 \%$ (cinquenta por cento) dos percentuais previstos nessa lei para cumprimento de metas nacionais de proteção à biodiversidade ou de redução de emissão de gases de efeito estufa (art. 13, II) (BRASIL, 2012).

O NCF inova em relação ao anterior ao discriminar estudos e critérios que devem ser levados em consideração para a definição da localização da área de RL. Dentre os citados no art. 14, destacam-se três estudos ou critérios: (i) a formação de corredores ecológicos com outras áreas protegidas, (ii) a ocorrência de áreas de maior importância para a conservação da biodiversidade e (iii) a existência de áreas de maior fragilidade ambiental (BRASIL, 2012).

A Lei $n^{\circ} 12.651$ de 2012 (NCF) prevê também que a área de RL deverá ser registrada no órgão ambiental competente por meio de inscrição no CAR. O CAR possibilitou ao proprietário rural a desobrigação de averbação no Cartório de Registro de Imóveis da RL, conforme era previsto no Código Florestal de 1965.

A RL pode também ser instituída por um grupo de proprietários de imóveis rurais que se associam em regime de condomínio para formar a porcentagem exigida da RL do conjunto de propriedades envolvidas, desde que sejam respeitados os percentuais previstos no art. 12 para cada imóvel (BRASIL, 2012). Esta possibilidade de formação de condomínio entre proprietários é uma alternativa para que aqueles que não possuem em seus imóveis o percentual mínimo de RL possam se unir e escolher uma área em um dos imóveis ou mesmo adquirir uma área preservada em outro imóvel e destiná-la como RL do condomínio de propriedades. Nesses termos, é possível a constituição da RL em regime de condomínio ou de maneira coletiva de acordo com o NCF.

Uma das mudanças mais controversas do antigo para o NCF ocorreu nas regras de cômputo das APPs nas áreas de RL. O novo código, no art. 15, admite o cômputo das APPs no 
cálculo do percentual da RL do imóvel, que se restringia à "vegetação nativa em área de preservação permanente" no código anterior. As condicionantes para isso são de que esse procedimento não implique a conversão de novas áreas para o uso alternativo do solo, de que a área a ser computada esteja conservada ou em processo de recuperação (conforme comprovação do proprietário ao órgão estadual integrante do Sisnama) e de que o proprietário ou possuidor tenha requerido inclusão do imóvel no CAR (BRASIL, 2012). Vale ressaltar que esse mecanismo não deverá ser autorizado caso ele implique a supressão de novas áreas de vegetação nativa. Dessa forma, cumpridos todos os requisitos, toda e qualquer APP, sem considerar o percentual que ocupa na propriedade, poderá ser computada como área de RL. No entanto, de acordo com diversos estudos, as APPs não poderiam estar incluídas no cômputo da área de RL do imóvel, uma vez que as comunidades biológicas, as estruturas e as funções ecossistêmicas das APPs e das RLs são distintas (CARVALHO, 2016).

A função das APPs, em sua origem, mais ligada à proteção dos recursos hídricos e do solo, foi ampliada e atualmente inclui a preservação dos recursos hídricos, da paisagem, da estabilidade geológica e da biodiversidade, além da facilitação do fluxo gênico da fauna e flora, a proteção do solo e a garantia do bem-estar das populações humanas. De acordo com Sparovek (2012) e Silva (2012), dadas as posições geograficamente definidas das APPs e suas funções ecossistêmicas, que proporcionam a proteção ambiental, a possibilidade de compensação de sua existência em outras posições da paisagem não se aplica.

Os proprietários e possuidores rurais que detinham, em 22 de julho de 2008, área de RL em extensão inferior ao estabelecido no artigo 12 no NCF (80\%, 35\% ou 20\%, a depender da localização e do bioma) poderão regularizar a sua situação, independentemente da adesão ao Programa de Regularização Ambiental (PRA), ao contrário do que ocorre com as APPs, adotando as seguintes alternativas, isoladas ou conjuntamente: $\mathrm{I}$ - recompor a $\mathrm{RL}^{10}$; II - permitir a regeneração natural da vegetação na área de RL; III - compensar a RL. O NCF admite a compensação da RL ao permitir, grosso modo, que o proprietário que possui em seu imóvel

\footnotetext{
${ }^{10}$ A recomposição consiste no reflorestamento da RL degradada, de acordo com os critérios definidos pelo órgão ambiental, permitindo o NCF que haja o plantio intercalado de espécies nativas regionais e exóticas, em sistema agroflorestal, desde que a área recomposta com espécies exóticas não exceda a 50\% da área total a ser recuperada. Além disso, a recomposição deverá ser concluída em até 20 anos, abrangendo, a cada 2 anos, no mínimo 1/10 (um décimo) da área total necessária à sua complementação. O proprietário ou possuidor do imóvel que optar por recompor a vegetação poderá explorar economicamente a RL. Outro ponto que chama a atenção é a possibilidade de recomposição da RL com espécies exóticas. No código antigo, elas somente poderiam ser utilizadas como pioneiras, já no NCF, além de poderem ser utilizadas na recomposição com frutíferas, o proprietário ainda pode explorá-las economicamente (art. 66, $\S 3^{\circ}$ e $4^{\circ}$ ). O disposto anteriormente será aplicável tanto para aqueles proprietários que não averbaram a área de RL quanto para aqueles que averbaram, mas não recompuseram a área de modo integral (CAMPOS, 2017).
} 
área de RL que não alcança os parâmetros estipulados pela legislação compense-os em outra que possua excedente, conforme se verá nos itens a seguir.

Nesses termos, a lei criou o conceito de áreas consolidadas em RL, ou seja, áreas que foram ocupadas irregularmente com atividades agrícolas, pastoris ou com silvicultura antes de 22 de julho de 2008. Para as propriedades que possuem áreas consolidadas, a lei estabelece regras especiais de conservação e uso do solo e institui parâmetros mais flexíveis para a regularização ambiental (CHIAVARI; LOPES, 2016, p. 4).

No caso das propriedades rurais com até 4 módulos fiscais ${ }^{11}$ até 22 de julho de 2008 e que possuam um remanescente de vegetação nativa, existe um tratamento legal favorável, pois, mesmo não possuindo os percentuais mínimos de RL, não haverá a necessidade de sua recomposição, visto que o artigo 67 do NCF admite que a RL será composta pela área ocupada com a vegetação nativa existente em 22 de julho de 2008, vedadas novas conversões para uso alternativo do solo ${ }^{12}$.

Conforme exposto anteriormente, a terceira opção, de acordo com o artigo 12 do NCF, que o proprietário ou possuidor tem para regularizar sua RL é a compensação que poderá ser efetivada mediante:

Art. $66[\ldots] \S 5^{\circ}$ A compensação de que trata o inciso III do caput deverá ser precedida pela inscrição da propriedade no CAR e poderá ser feita mediante: I - aquisição de Cota de Reserva Ambiental - CRA;

II - arrendamento de área sob regime de servidão ambiental ou Reserva Legal; III - doação ao poder público de área localizada no interior de Unidade de Conservação de domínio público pendente de regularização fundiária;

IV - cadastramento de outra área equivalente e excedente à Reserva Legal, em imóvel de mesma titularidade ou adquirida em imóvel de terceiro, com vegetação nativa estabelecida, em regeneração ou recomposição, desde que localizada no mesmo bioma (BRASIL, 2012).

Em se tratando de compensação por outra área, a regra é que esta deve se localizar no mesmo bioma ${ }^{13}$ e ser equivalente em extensão à área de RL a ser compensada. Se fora do estado,

\footnotetext{
${ }^{11}$ Módulo fiscal é uma unidade de medida agrária, expressa em hectares, criada para fins fiscais. Os módulos fiscais variam de 5 a 110 hectares, conforme o município (CHIAVARI; LOPES, 2016, p. 4).

${ }^{12}$ Chiavari e Lopes (2016) discorrem detalhadamente sobre as etapas, processos e diferenças existentes entre a regularização ambiental de imóveis rurais maiores ou menores do que 4 módulos fiscais.

${ }^{13}$ Os biomas brasileiros ocupam extensas áreas geográficas que abrangem um amplo espectro de condições ambientais, como diferentes tipos de solos, de condições climáticas e faixas de altitude. Essas diferenças fazem com que dentro de cada grande bioma exista uma diversidade de fisionomias vegetais marcadas por diferenças de composição de espécies e estruturas de ecossistemas. Nesse sentido, as compensações previstas indistintamente no âmbito do bioma poderão levar a trocas entre áreas que não têm equivalência ecológica em termos de composição de espécies, de estrutura ou de função. Isso significa, por exemplo, que um proprietário do interior de São Paulo, que deveria conservar uma RL de mata mesófila semidecídua, pode compensar a destruição irregular desta RL comprando uma área de mata ombrófila densa da Serra do Mar, ou mesmo uma área de mata em Pernambuco. Dessa forma, a compensação de RL desconsidera que as florestas e demais formações vegetacionais brasileiras são heterogêneas, resultado de complexos processos biogeográficos, sendo esta justamente a razão para
} 
deve estar localizada em áreas identificadas como prioritárias pela União ${ }^{14}$ ou pelos estados, buscando favorecer, entre outros, a recuperação de bacias hidrográficas excessivamente desmatadas, a criação de corredores ecológicos, a conservação de grandes áreas protegidas e a conservação ou recuperação de ecossistemas ou espécies ameaçadas.

A aprovação da localização será realizada pelo órgão ambiental estadual competente após a inscrição da totalidade da área no CAR (art. 14, $\S 1^{\circ}$, Lei $\mathrm{n}^{\circ} 12.651 / 2012$; art. $3^{\circ}$ do Decreto $n^{\circ}$ 8.235/2014) (BRASIL, 2012). Após o procedimento do cadastro, as propriedades com passivo ambiental relativo às APPs de RL deverão proceder à regularização ambiental mediante adesão aos PRAs dos estados ${ }^{15}$ e do Distrito Federal (art. 3, $\S 2^{\circ}$, Decreto Federal $n^{\circ}$ $8.235 / 2014)$.

Chiavari e Lopes (2017, p. 3) analisam as alternativas para compensação de RL, ressaltando as vantagens e desvantagens inerentes a cada modalidade, para, em seguida, descreverem e analisarem os principais dispositivos sobre as CRAs ${ }^{16}$, previstos no NCF, tais como os procedimentos de emissão, de registro, de compensação de RL, de transferência e cancelamento do título. Segundo as autoras:

[...] das quatro alternativas para a compensação de Reserva Legal, a aquisição de CRA parece ser a mais vantajosa para o compensador, pois não exige a contratação de assistência técnica e jurídica, não envolve a compra nem a manutenção da vegetação nativa de outro imóvel rural e tem um procedimento de compensação de Reserva Legal mais simples que as demais opções (CHIAVARI; LOPES, 2017, p. 4).

O presente trabalho se restringirá à análise da compensação de RL mediante doação ao poder público de área localizada no interior de UC pendente de regularização fundiária, tema que será tratado no próximo item.

que essas áreas sejam reconhecidas internacionalmente pela sua alta biodiversidade. As compensações deveriam ser realizadas somente em áreas ecologicamente equivalentes, considerando não apenas as regiões de endemismo, mas também as diferenças de composição de espécies e estrutura dos ecossistemas que ocorrem dentro das subdivisões de cada grande bioma brasileiro. Mesmo assim, é importante notar que qualquer compensação de perda da RL em uma região realizada em outra área não repõe os serviços ecossistêmicos que a RL perdida prestava na sua área original, nem impede a degradação ambiental progressiva que tal perda provoca (JOLY et al., 2011; SILVA, 2012; SILVA; RANIERI, 2014; METZGER, 2010).

${ }^{14} \mathrm{O}$ mapa das áreas prioritárias para a conservação no Brasil e a recomendação de uso dessas áreas está disponível nos seguintes links: <http://www.mma.gov.br/estruturas/chm/_arquivos/maparea.pdf>, <http://www.mma.gov.br/estruturas/chm/_arquivos/tabmapa.pdf>, acesso em ago. 2018.

${ }^{15}$ A efetiva implementação da regularização ambiental dos imóveis rurais se dará no âmbito estadual. As regras federais servem de regras gerais que orientarão os estados na elaboração de suas normas. Nesse sentido, os estados têm uma ampla margem na regulamentação do NCF e uma grande oportunidade de estabelecer procedimentos claros e simples sem abrir mão de parâmetros e critérios que garantam uma efetiva proteção do meio ambiente. Porém, essa flexibilidade, dependendo da coalização de forças presente em cada estado, pode gerar conflitos de poderes, aumentando as incertezas na implementação do NCF (CHIAVARI; LOPES, 2016).

${ }^{16}$ Existem diversos estudos sobre a compensação de RL pelo mecanismo da CRA. São estes: Instituto de Pesquisa Ambiental da Amazônia (IPAM, 2015), Monzoni e Vendramini (2015), Rajão e Soares-Filho (2015), Bernasconi (2013), Freitas, Sparovek e Matsumoto (2016), May et al. (2015). 


\subsection{O NCF e a compensação de Reserva Legal por doação de área de Unidades de Conservação}

De acordo com o NCF, a compensação de RL mediante doação ao poder público de área localizada no interior de UC de domínio público pendente de regularização fundiária refere-se à possibilidade legal dada a um produtor rural que desmatou a sua RL antes de 2008 de sanar esse déficit de RL mediante a compra de uma outra área (de um proprietário rural) inserida no interior de uma UC, para que doe posteriormente essa área ao poder público (BRASIL, 2012). Os primeiros esforços para implementação de compensação de RL por doação, em nível federal, foram geridos pelo Ibama, que era o órgão responsável pela gestão das UCs antes da criação do ICMBio (SARETTA, 2017).

O Ibama, para viabilizar os processos de desoneração ${ }^{17}$ de RL por doação de área ao poder público, expedia editais de chamamento público. Esses editais propiciavam maior transparência e divulgação do processo de desoneração de RL a ofertantes e demandantes de áreas (SARETTA, 2017).

O primeiro edital foi publicado em 2006, visando à regularização fundiária do Parque Nacional de Ilha Grande (localizado na divisa dos estados do Paraná e Mato Grosso do Sul) com base no art. 44, $\S 6^{\circ}$, da Lei $n^{\circ} 4.771 / 65$ (Código Florestal em vigor na época). Segundo Saretta (2017), as primeiras tentativas não foram tão bem-sucedidas quanto o Ibama esperava à época, já que o Ministério Público do Paraná foi contrário à implementação do mecanismo e suspendeu as ações que estavam em curso.

Com a criação do ICMBio, em 2007, a competência pela gestão das UCs passou a ser deste órgão e não mais do Ibama. A IN do ICMBio $\mathrm{n}^{\circ} 2$, de 2009, foi o arcabouço legal que orientou o processo administrativo das desonerações/compensações e os procedimentos técnicos e administrativos para a indenização de benfeitorias e desapropriações (SARETTA, 2017).

Para dar divulgação ao processo, o ICMBio publicou editais com a chamada para as desonerações, assim como fazia o Ibama. No mais, esse instituto disponibilizou também um requerimento para que os proprietários no interior de UCs pudessem requerer análise de conformidade processual para a participação do processo de compensação de RL (SARETTA, 2017).

\footnotetext{
${ }^{17}$ Essa modalidade de compensação de RL no Código Florestal antigo era denominada “desoneração", como será analisado no item 3.4 deste capítulo.
} 
O primeiro caso de compensação ambiental de RL em UC foi o Parque Nacional Serra da Canastra, em Minas Gerais, em 2009, gerando uma economia de recursos para os cofres públicos de R\$29,3 milhões ${ }^{18}$ (CHEADE et al., 2014). Desde essa primeira compensação realizada em UC federal pelo ICMBio, várias compensações foram realizadas até o ano de 2017. Segue tabela com as áreas habilitadas e doadas ao instituto.

Tabela 1 - Áreas habilitadas em hectares (ha) e doadas pela compensação de RL para o poder público

\begin{tabular}{c|c|c|c|c|c|c}
\hline Unidade de conservação & Bioma & UF & $\begin{array}{c}\text { Área } \\
\text { habilitada }\end{array}$ & $\begin{array}{c}\text { Área } \\
\text { doada }\end{array}$ & $\begin{array}{c}\text { Imóveis } \\
\text { doados }\end{array}$ & $\begin{array}{c}\text { Área } \\
\text { pendente } \\
\text { de } \\
\text { doação }\end{array}$ \\
\hline $\begin{array}{c}\text { Parque Nacional da Serra de } \\
\text { Bodoquena }\end{array}$ & $\begin{array}{c}\text { Cerrado e Mata } \\
\text { Atlântica }\end{array}$ & MS & $4^{\prime} 005.92$ & 96.30 & 2 & $3^{\prime} 909.62$ \\
\hline Parque Nacional de Ilha Grande & Mata Atlântica & PR & $2^{\prime} 154.93$ & 448.23 & 18 & $1^{\prime} 706.70$ \\
\hline Parque Nacional de Itatiaia & Mata Atlântica & MG/RJ & $3^{\prime} 335.27$ & 139.00 & 1 & $3^{\prime} 196.27$ \\
\hline $\begin{array}{c}\text { Parque Nacional Grande Sertão } \\
\text { Veredas }\end{array}$ & Cerrado & BA/MG & $36^{\prime} 259.66$ & $1^{\prime} 572.09$ & 1 & $34^{\prime} 687.57$ \\
\hline $\begin{array}{c}\text { Parque Nacional Serra da } \\
\text { Canastra }\end{array}$ & Cerrado & MG & $4^{\prime} 410.54$ & $2^{\prime} 105.04$ & 17 & $2^{\prime} 305.51$ \\
\hline $\begin{array}{c}\text { Reserva Biológica Da Mata } \\
\text { Escura }\end{array}$ & Mata Atlântica & MG & $5^{\prime} 750.83$ & 729.26 & 2 & $5^{\prime} 021.57$ \\
\hline $\begin{array}{c}\text { Reserva Extrativista Rio Ouro } \\
\text { Preto }\end{array}$ & Amazônia & RO & $1^{\prime} 199.10$ & $1^{\prime} 199.10$ & 5 & 0.00 \\
\hline \multicolumn{2}{c|}{ Totalização } & & $57^{\prime} 116.25$ & $6^{\prime} 289.02$ & 46 & $50^{\prime} 827.23$ \\
\hline
\end{tabular}

Fonte: ICMBio (2016).

A compensação por meio da doação de imóvel em UC federal, estadual ou municipal de domínio público pendente de regularização fundiária depende de regulamentação estadual. Alguns estados já instituíram procedimentos próprios $^{19}$, porém a maioria ainda não editou legislação específica (CHIAVARI; LOPES, 2016, 2017).

O ICMBio publicou, em 19 de maio de 2016, por meio da $\mathrm{IN} \mathrm{n}^{\circ} 5$, os procedimentos para implementação da modalidade de compensação de RL por doação. Essa IN dispõe sobre o objetivo do mecanismo (regularização fundiária das UCs de domínio público), aporta a fundamentação legal que o ampara, traz os conceitos inerentes a sua implementação e os

\footnotetext{
${ }^{18}$ No Parque Nacional Serra da Canastra, entre 2009 e 2014, mais de 11.000 hectares foram regularizados dentro da UC por meio desse mecanismo legal, o que significa 9,1\% da sua área total (CHEADE et al., 2014).

${ }^{19}$ Bernardo (2010) analisou a influência das características institucionais dos sistemas de RLs adotados nos estados do Mato Grosso do Sul, Minas Gerais e Paraná, por meio de indicadores de êxito na averbação e na aplicação do mecanismo de compensação de RL, nos sistemas de informação, nas leis e normas referentes ao procedimento de averbação, assim como a comunicação interna e externa das instituições envolvidas com esse mecanismo.
} 
procedimentos administrativos e suas etapas, dispõe sobre os documentos exigidos em cada uma das etapas e os procedimentos para a doação em $\mathrm{si}^{20}$.

Resumidamente, o processo no ICMBio (IN no 5/2016) inicia-se com a instauração de um procedimento administrativo pelo proprietário que pretende ceder a área em UC. Este deve apresentar uma série de documentos ao órgão gestor da UC. Após a análise dos documentos, é emitida uma certidão de habilitação para fins de compensação de RL. O ICMBio divulga no site da instituição a lista dos imóveis habilitados, e o proprietário que tem interesse em compensar a sua área de RL deve entrar em contato com o proprietário-cedente para realizar a compra do imóvel. Após a compra, o proprietário-compensador deve tratar da doação e do registro imobiliário do imóvel ao ICMBio (CHIAVARI; LOPES, 2016, 2017).

Seguem as etapas importantes referentes à $\mathrm{IN} \mathrm{n}^{\circ} 5$, de 19 de maio de 2016:

1) CAR - o imóvel a ser doado deve ter o prévio cadastramento no CAR;

2) Imóvel sem edificações - O imóvel a ser doado deve ser livre, desembaraçado e sem edificações do seu titular ou de terceiros. Contudo, a IN dispõe também que, em havendo interesse do ICMBio na permanência de alguma benfeitoria do imóvel, esta poderá ser mantida;

3) O imóvel poderá ser doado inteiro ou em parte - O cedente ou beneficiário poderá optar pela doação da integralidade do imóvel ao ICMBio, pela doação do equivalente ao mínimo exigível para fins de compensação de RL e desapropriação da área remanescente ou, ainda, poderá optar pela oferta a beneficiários que tenham interesse em adquirir o imóvel para os fins desta IN;

4) Só podem ser doadas áreas que se sobrepõem às UCs - Nas hipóteses de doação de imóveis que se sobrepõem apenas parcialmente às UCs, somente a parcela que as integra será considerada para fins de compensação de RL;

5) A negociação é entre privados - O processo de compra e venda será realizado entre o beneficiário e o cedente, não havendo interferência e/ou participação da autarquia nesse processo, especialmente no que se refere à definição dos valores transacionados.

São etapas do procedimento da $\mathrm{IN}^{\circ} 5$ :

I - instauração e instrução do processo;

II - análise técnica relativa à fase de emissão de certidão;

III - certidão para fins de compensação de RL;

\footnotetext{
${ }^{20}$ Para UCs federais, vale o disposto no próprio Código Florestal e na IN ${ }^{\circ}$ 5/2016 do ICMBio. Para as UCs
} estaduais, será necessária uma regulamentação a nível estadual. 
IV - vistoria técnica para fins de constatação da inexistência de ocupações e apresentação de novos documentos;

V - análise técnica relativa à fase de escrituração e registro;

VI - análise jurídica da Procuradoria Federal Especializada com o ICMBio quanto à regularidade da instrução processual;

VII - decisão administrativa da respectiva Coordenação Regional do instituto;

VIII - escrituração da doação ao ICMBio e respectivo registro imobiliário.

De acordo com a IN $n^{\circ}$, as etapas do procedimento, a depender das circunstâncias, poderão ter sua ordem de observância alterada em razão do princípio da eficiência e em prol da razoabilidade e da racionalidade no emprego dos recursos públicos (ICMBIO, 2016).

Todos os procedimentos listados anteriormente são divididos em duas fases. A fase I tem como objetivo a expedição da Certidão para Compensação de Reserva Legal e a fase II trata da doação e registro imobiliário do imóvel em nome do ICMBio (ICMBIO, 2016).

O NCF permite que duas ou mais propriedades formem RL em regime de condomínio, conforme já apresentado no item sobre a RL. A novidade é que a IN $n^{\circ} 5$ previu que a compensação de RL por doação poderá também se beneficiar do regime de condomínio. Segundo o artigo $5^{\circ}$ da IN n ${ }^{\circ}$ 5: "O imóvel do cedente, com certidão emitida pelo ICMBio, poderá ser adquirido em regime de condomínio pelos beneficiários" (ICMBIO, 2016). Essa previsão reduz o descompasso entre áreas grandes a serem doadas dentro de UC e proprietários rurais que demandam uma área pequena para a compensação de RL. Vários proprietários que pretendem compensar a RL podem adquirir uma grande área dentro de uma UC pendente de regularização fundiária para doar ao ICMBio na forma de condomínio.

A IN n ${ }^{\circ} 5$ do ICMBio prevê ainda que, quando o condomínio não abranger toda área do imóvel, deverá ser realizado o desdobramento da matrícula do imóvel, ficando o saldo de área como remanescente da matrícula originária (ICMBIO, 2016).

O Quadro 1 resume as principais características do mecanismo de doação de área em UC de domínio público pendente de regularização fundiária. 
Quadro 1 - Principais características da compensação de RL por doação de área em UC de domínio público pendente de regularização fundiária

\begin{tabular}{|l|l|}
\hline Legislação & $\begin{array}{l}\text { Para UC federal: Código Florestal e IN ICMBio no } \\
5 / 2016 . \\
\text { Para UC estadual: depende da legislação florestal de } \\
\text { cada estado. }\end{array}$ \\
\hline Negociação & $\begin{array}{l}\text { Entre particulares, mas há necessidade de intervenção } \\
\text { do órgão gestor da UC. }\end{array}$ \\
\hline $\begin{array}{l}\text { Necessidade de assistência técnica e } \\
\text { jurídica }\end{array}$ & Sim \\
\hline Prazo de vigência & Perpétua \\
\hline $\begin{array}{l}\text { Possibilidade de cancelamento antes do } \\
\text { término do prazo }\end{array}$ & Não \\
\hline Registros & $\begin{array}{l}\text { Não há previsão legal exigindo averbação na matrícula } \\
\text { do imóvel. }\end{array}$ \\
\hline $\begin{array}{l}\text { Responsabilidade pela conservação e e } \\
\text { monitoramento da vegetação nativa }\end{array}$ & $\begin{array}{l}\text { O gestor da UC é responsável pela conservação e } \\
\text { monitoramento da vegetação nativa. }\end{array}$ \\
\hline
\end{tabular}

Fonte: Adaptado a partir de Chiavari e Lopes (2017).

Saretta (2017) realizou uma pesquisa sobre as principais vantagens, dificuldades e desafios relatados por especialistas acerca da implementação do mecanismo de compensação de RL em UC de domínio público. Segundo a autora, a maior vantagem desse instrumento é a desoneração de recursos financeiros aos cofres públicos decorrente da obrigação indenizatória da desapropriação. Quanto às dificuldades e desafios, a autora refere-se à falta de confiabilidade nos documentos fundiários em relação à dominialidade das terras inseridas nas UCs, fato que vem tornando o mecanismo de compensação de RL por doação inviável em todo o Brasil.

A insegurança da propriedade das terras no interior das UCs é a principal dificuldade para se realizar as compensações de RL em UC. Algumas áreas de UC são um verdadeiro imbróglio jurídico, e até mesmo o ICMBio reconhece essas dificuldades, já que nos antigos processos fundiários não era realizado o georreferenciamento das áreas (SARETTA, 2017).

Conforme o exposto, um dos grandes desafios do poder público é o fortalecimento da confiabilidade dos dados fundiários. Cheade et al. (2014), citando a entrevista realizada com Eliani Maciel (da Coordenação Geral de Consolidação Territorial do ICMBio), afirmam que um dos desafios da compensação é a definição e capacitação de equipes para trabalhar com processos de regularização fundiária com ênfase em compensação de RL, com análise documental, montagem das cadeias dominiais e capacitação em geoprocessamento para operação das malhas fundiárias. 
Também foi destacado por Saretta (2017) que o processo de compensação de RL por doação de área de UC é difícil, pois exige dois atos jurídicos: compra e venda e posterior doação. Dependendo do estado, o procedimento de doação ao poder público de propriedade em UC para fins de compensação de RL pode ser bastante burocrático e longo (CHIAVARI; LOPES, 2017, p. 4).

\subsection{Histórico da compensação de Reserva Legal: da MP $n^{0}$ 1.511/96 ao NCF (Lei $n^{0}$ 12.651/2012)}

O processo de reforma do NCF foi marcado por um intenso debate na sociedade mobilizando o setor público e privado, ONGs, governo e cientistas. Os debates eram sobre uma série de pontos polêmicos em relação à preservação ambiental e à produção rural. A reforma foi discutida no Congresso Nacional por mais de uma década (CAMPOS, 2017; CUNHA, 2013).

Como ponto de partida, é importante entender que os produtores rurais, desde a criação do instituto da RL, em 1934, até o NCF, em 2012, não cumpriram efetivamente com as suas obrigações de manutenção da RL e das APPs em suas propriedades. Conforme aponta Cunha (2013), as regras do Código Florestal, principalmente aquelas referentes à RL, sempre foram ignoradas pelo setor produtivo rural.

Ao tratar das razões que levaram à não conformidade dos proprietários rurais em relação ao Código Florestal, Sparovek (2012) aponta, para além da não aceitação das restrições pelos produtores, a falta de fiscalização do Estado e as constantes mudanças na legislação. Outros fatores também implicaram a não preservação e recuperação das áreas de RL, como o elevado custo de oportunidade de conservação, associado ao abandono de oportunidades de converter a terra em usos rentáveis (principalmente nas unidades da federação com uso intensivo do solo), e os encargos financeiros que a recuperação das áreas naturais gera aos proprietários rurais (SPAROVEK et al., 2011).

No ano de 2010, estimava-se que, dos 278 milhões de hectares ocupados pelo setor agropecuário no Brasil, pelo menos 83 milhões estavam em situação de não conformidade com o Código Florestal e teriam que ser recuperados (SPAROVEK et al., 2010).

Os debates sobre a reformulação do Código Florestal de 1965 iniciaram-se na década de 1990, quando a taxa de desmatamento na Amazônia voltou a se elevar, atingindo o pico em 1995 (INPE, 1997 apud CHIAVARI; LOPES, 2016, p. 24). A divulgação das estatísticas oficiais constatando o crescimento da taxa de desmatamento anual na região amazônica fez 
parte do cenário da Conferência das Nações Unidas sobre o Meio Ambiente e o Desenvolvimento (RIO-92), na qual os temas ambientais tiveram bastante visibilidade (MELLO, 2006 apud SARETTA, 2017; CHIAVARI; LOPES, 2016).

Foi nesse contexto que o então presidente da República, Fernando Henrique Cardoso, com o objetivo de tornar mais rigorosa a proteção ambiental do bioma Amazônia (SILVA et al., 2010), adotou medidas mais rígidas contra o desmatamento ${ }^{21}$. Assim, foi editada a MP $\mathrm{n}^{\text {o }}$ 1.511, de 25 de julho de $1996^{22}$, alterando o Código Florestal de 1965, com o objetivo de aumentar a proteção das florestas localizadas em propriedades rurais na Amazônia (CHIAVARI; LOPES, 2016, p. 24; CUNHA, 2013, p. 56-65).

Essa modificação da legislação "provocou imediata e indignada reação do setor produtivo e de seus representantes no Congresso Nacional" (BENJAMIN, 2000a apud CUNHA, 2013, p. 65) e acabou estimulando um movimento em favor de sua revisão. Para Cunha (2013), essa MP foi o estopim de um processo conflituoso que se estendeu até o desmonte do Código Florestal de 1965, inaugurando a edição de uma série de MPs que alteraram de forma significativa as disposições do Código Florestal sobre a RL. De julho de 1996 a agosto de 2001, 68 MPs foram editadas mês a mês e mudaram diversos pontos do antigo Código Florestal brasileiro (CUNHA, 2013).

De 2009 a 2012, a proposta de revisão do código então vigente foi marcada por conflitos e debates envolvendo diversos atores sociais: produtores rurais, ambientalistas, cientistas, ONGs, parlamentares e governo. Cunha (2013) dedicou-se a entender tanto as regras referentes às MPs como o comportamento de atores políticos relacionado às decisões sobre a mudança no Código Florestal. Esse autor demonstra que as negociações envolvendo tais decisões eram discutidas principalmente entre o Executivo e membros de sua coalizão, muitos dos quais ligados à bancada ruralista. Se, de um lado, o governo de Fernando Henrique Cardoso fazia concessões para que as principais diretrizes da MP $\mathrm{n}^{\mathrm{o}}$ 1.511/1996 fossem mantidas, dentre as quais a RL de $80 \%$ na Amazônia, por outro lado, o Executivo introduzia várias agregações e alterações no Código Florestal. A partir da 30ª reedição da MP (nº 1.605/1998), foi instituído o mecanismo de compensação de RL na Amazônia (BENJAMIN, 2000a apud CUNHA, 2013).

\footnotetext{
${ }^{21}$ Segundo Silva et al. (2010), a preocupação do governo com a decisão de expedir essa MP não era o meio ambiente em si, mas a imagem do país no exterior, evidenciada pela participação do Ministério de Relações Exteriores com o Ministério do Meio Ambiente e o Ministério de Ciência e Tecnologia na redação da justificativa para a tomada de tal MP.

${ }^{22}$ As principais inovações foram: i) proibição de corte raso de $80 \%$ nas propriedades onde a cobertura arbórea fosse constituída por florestas; ii) obrigatoriedade de averbação da RL na matrícula do imóvel; iii) proibição de conversão de áreas de vegetação nativa em áreas agrícolas em propriedades com áreas desmatadas e subaproveitadas; iv) obrigatoriedade de exploração da cobertura florestal nativa na região amazônica somente por meio de manejo florestal sustentável (CHIAVARI; LOPES, 2016, p. 24; SARETTA, 2017).
} 
A despeito de o mecanismo flexibilizar a alocação da RL na Amazônia, os critérios definidos para que essa compensação pudesse ocorrer eram bastante restritos.

Saretta (2017), citando Silva et al. (2010), argumenta que o ápice do retrocesso em relação às medidas de proteção florestal do antigo Código Florestal foi quando, em dezembro de 1999, o deputado federal Moacir Micheletto levou ao Congresso Nacional o projeto de lei de conversão da MP n ${ }^{\circ} 1.736$, então em sua $39^{a}$ edição. A proposta apresentada pelo deputado Micheletto introduzia várias medidas que reduziam a proteção ambiental nas propriedades privadas, entre estas, a revogação da proibição de corte raso de $80 \%$ nas áreas de floresta situadas na Amazônia Legal a título de RL (SARETTA, 2017).

Nesse contexto, o Instituto Socioambiental (ISA) iniciou e liderou uma mobilização que contou com o apoio da sociedade brasileira contra a proposta que o deputado federal Moacir Micheletto intentava levar à votação (SILVA et al., 2000). A mobilização iniciada pelo ISA foi apoiada por políticos ligados à questão ambiental, como a senadora Marina Silva (PT/AC), os deputados Fernando Gabeira (PV/RJ) e José Genoino (PT/SP), além do ministro Sarney Filho (PFL/MA) (CUNHA, 2013; BENJAMIN, 2000b apud SARETTA, 2017).

A mobilização causada pelo projeto de lei do deputado federal Moacir Micheletto fez com que o governo suspendesse as votações acerca das alterações do Código Florestal e autorizasse o Conama a trabalhar uma proposta alternativa que buscasse converter a MP vigente à época em lei (CUNHA, 2013).

O Conama, por deliberação do presidente Fernando Henrique Cardoso, em abril de 1999, estabeleceu a Câmara Técnica Temporária do Código Florestal, com a finalidade de que os membros dessa câmara elaborassem uma proposta de anteprojeto de lei de atualização do Código Florestal (SARETTA,2017). A referida Câmara Técnica elaborou uma proposta de substitutivo ao Projeto de Lei $n^{\circ} 7 / 1999$, após intensos debates e realização de vinte e cinco audiências públicas ocorridas em mais de vinte estados do país (ISA, 2000 apud SARETTA, 2017).

A proposta que saiu desse colegiado a partir da MP nº 1.956-50/2000, convertida em lei em 2001, estendeu o conceito da compensação de RL, antes restrito à Amazônia, a todo o país e criou novas modalidades de compensação de RL, tais como a servidão florestal e a Cota de Reserva Florestal (CRF). Ademais, foi previsto que o proprietário rural poderia ser desonerado $^{23}$, pelo período de 30 anos, das obrigações de manutenção da RL mediante a doação,

\footnotetext{
${ }^{23}$ A desoneração é um termo jurídico que significa liberação de ônus ou obrigação. No caso da desoneração instituída pela referida MP, significava que o proprietário rural que havia desmatado a sua RL poderia ser liberado
} 
ao órgão ambiental competente, de área localizada no interior de parque nacional ou estadual, floresta nacional, reserva extrativista, reserva biológica ou estação ecológica pendente de regularização fundiária, respeitados os critérios previstos no inciso III desse artigo (SARETTA, 2017).

Naquela época, a desoneração não era enquadrada como uma forma de compensação de RL, pois deixava implícita a ideia de uma desoneração temporária, com vigência de 30 anos. Decorrido aquele prazo, o proprietário que havia sido desonerado deveria, a partir de então, recuperar a sua RL. Nessa linha, não havia redução efetiva do montante de RL em prol da consolidação das UCs (apenas uma redução temporária de 30 anos), e o ganho das UCs era perpétuo e efetivo (SARETTA, 2017).

O critério para que estas compensações de RL fossem realizadas, por servidão, CRF ou desoneração, era que elas poderiam ocorrer em outra área equivalente em importância ecológica e extensão, desde que pertencessem ao mesmo ecossistema e estivessem localizadas na mesma microbacia, conforme critérios estabelecidos em regulamento. A lei dispunha ainda que, na impossibilidade de a compensação da RL ser efetivada dentro da mesma microbacia hidrográfica, o órgão ambiental estadual competente deveria aplicar o critério de maior proximidade possível entre a propriedade desprovida de RL e a área escolhida para compensação, desde que na mesma bacia hidrográfica e no mesmo estado, atendido, quando houvesse, o respectivo Plano de Bacia Hidrográfica e respeitadas as demais condicionantes estabelecidas (BRASIL, 2000 apud SARETTA, 2017). Este critério de compensação na mesma microbacia era bastante impreciso, prejudicando sua implementação. Vários atores foram críticos à rigidez desses critérios ${ }^{24}$.

Entre as alterações previstas pela referida MP, os mecanismos de compensação de RL, assim como o mecanismo de desoneração, passariam a ser submetidos à aprovação do órgão ambiental estadual, configurando uma mudança em relação à previsão anterior que dispunha que o órgão federal era o competente por aprovar as compensações fora da propriedade (SARETTA, 2017).

\footnotetext{
da obrigação de recompor a sua RL ou de conduzir a regeneração natural daquela RL ou ainda de compensar a RL por 30 anos mediante a doação, ao órgão ambiental competente, de área localizada no interior de UC de domínio público pendente de regularização fundiária, respeitados os critérios previstos naquela lei (BRASIL, 2000 apud SARETTA, 2017).

${ }^{24}$ Entre os diversos argumentos apontados sobre a baixa taxa de implementação da compensação de RL na mesma bacia hidrográfica, o argumento comum encontrado em diversos autores é a falta de áreas com vegetação nas mesmas bacias hidrográficas onde ocorriam os déficits de RL (SPAROVEK et al., 2011; BERNASCONI, 2013; SARETTA, 2017). Um outro aspecto, mencionado por Irigaray (2007), refere-se à dificuldade de aquisição de fração de imóveis por parte de proprietários rurais que possuam um passivo de RL inferior à dimensão do módulo rural na mesma bacia hidrográfica.
} 
A Lei $n^{0} 11.284$ de 2006 alterou esse mecanismo. Ela foi inicialmente estabelecida para a Mata Atlântica e logo estendida para todo o território nacional. A desoneração, que era prevista por 30 anos, foi estendida a uma desoneração perpétua. Isso significa que, com a nova lei, aquele que doasse uma área pendente de regularização fundiária ao poder público para compensar o seu déficit de RL estaria perpetuamente desonerado da obrigação com a sua RL (SARETTA, 2017). A possibilidade de se utilizar o mecanismo de compensação naquela época era para quem havia desmatado a sua RL antes de 1998 (Lei n 11.284/2006). Quem houvesse desmatado depois desse corte temporal não poderia gozar do mecanismo da desoneração e deveria recuperar a sua RL.

$\mathrm{O}$ instrumento de compensação de RL gerou críticas que alegavam a redução do montante de RL em prol de um espaço já protegido. Essas críticas resultaram, em 2010, em uma ADI ajuizada, pelo Ministério Público Federal (MPF), contra o mecanismo.

Em 2008, foi regulamentada a lei de crimes ambientais, colocando mais de $90 \%$ do universo de 5,2 milhões de propriedades rurais do país na ilegalidade (SARETTA, 2017). Na prática, a aprovação da nova lei, em vez de punir os proprietários que não estavam de acordo com a legislação de crimes ambientais, implicou a anistia das multas e sanções decorrentes de desmatamento ilegais realizados antes da promulgação da Lei de Crimes Ambientais e a isenção, principalmente para os pequenos produtores, da obrigatoriedade de recuperar áreas desmatadas. Nesse sentido, 22 de julho de 2008, quando foi regulamentada a Lei de Crimes Ambientais por meio do Decreto $n^{\circ} 6.514 / 2008$, tornou-se a data de referência na anistia de proprietários que desmataram suas áreas de RL, no NCF (SARETTA, 2017).

Diante desse cenário, em 2009, foi criada a Comissão Especial para analisar os diversos projetos de lei de alteração do Código Florestal, sendo nomeado o deputado Aldo Rebelo (PC do B-SP) como relator do projeto. Essa Comissão Especial foi permeada por "conflitos" entre o setor rural, ambiental, o governo e o meio acadêmico. Entre os diversos aspectos do projeto, pelo menos quatro geraram grande polêmica: a regulação sobre APPs e RL; as atividades produtivas permitidas em áreas protegidas; a definição e competências em matéria ambiental; e os incentivos visando à recomposição de APP e áreas de RL. Muitos desses conflitos foram materializados em ADIs, como veremos no próximo item.

\subsection{O NCF e as Ações Diretas de Inconstitucionalidade}

O NCF foi polêmico, uma vez que instituiu uma série de mecanismos que propiciaram um padrão de proteção ambiental inferior ao anteriormente existente (CAMPOS, 2017). Com 
a nova lei, estima-se que a área de passivos nas propriedades rurais tenha se reduzido quatro vezes, o que representa 4,5 milhões de hectares para as APPs (SOARES-FILHO et al., 2014) e de 13,1 milhões de hectares (FREITAS; SPAROVEK; MATSUMOTO, 2016) a 16,3 milhões de hectares (SOARES-FILHO et al., 2014) para as áreas de RL.

Em razão desse fato, foram ajuizadas quatro ADIs: ADIs n 4.901, 4.902 e 4.903, pela Procuradoria-Geral da República em 18 de janeiro de 2013, ADI no 4.937, pelo Partido Socialismo e Liberdade (Psol) em 4 de abril de 2013. As ações possuíam como argumentos comuns, resumidamente, a afronta aos deveres fundamentais do poder público para garantia do direito ao meio ambiente ecologicamente equilibrado, já que normas impugnadas do NCF violariam o princípio da vedação de retrocesso ambiental.

A diminuição do padrão de proteção ambiental e até mesmo a extinção de espaços territoriais especialmente protegidos podem ser expressas na permissão da consolidação das áreas desmatadas antes de 2008, na redução das APPs, na possibilidade da compensação de RL ser realizada no mesmo bioma e na compensação de RL por doação e por CRA.

O principal ponto fraco da compensação de RL por doação - e também o principal argumento contrário ao mecanismo - é a potencial perda de cobertura vegetal de RL. Essa potencial perda de RL é real, já que a área que legalmente deveria ser uma RL pode deixar de existir perpetuamente se o seu proprietário se decidir por compensar o seu déficit se utilizando do mecanismo de compensação de RL por doação de área em UC de domínio público.

O mecanismo de compensação de RL por doação de área na UC de domínio público para o ICMBio ou para órgãos gestores municipais e estaduais fere o princípio da adicionalidade e o dever fundamental de reparação do dano ambiental ao prever que área com vegetação nativa preexistente passa a compensar outra área "consolidada" sem aumentar cobertura florestal, pelo contrário, autoriza a diminuição da área de proteção imposta por lei, violando ainda o princípio do não retrocesso socioambiental (SARETTA, 2017). Segundo Soares-Filho et al. (2014), 29 milhões de hectares de RL e matas ciliares desmatados ilegalmente foram anistiados em todo o país. Ademais, esse mecanismo transfere a responsabilidade ambiental do particular para o Estado, e este passa a custear o dever de reparação e manutenção da conservação ambiental (SARETTA, 2017).

Nesses termos, a compensação de RL por doação de área na UC para o ICMBio tem fins fundiários e não ambientais e evidencia a incapacidade de o Estado cumprir com seu dever de regularização fundiária. 
Como regra geral, o NCF mantém os mesmos princípios do Código Florestal anterior. Dessa forma, seu retrocesso não se encontra nos princípios da lei, mas nos procedimentos estabelecidos para sua implantação (CAMPOS, 2017). 


\section{GOVERNANÇA E ADMINISTRAÇÃO DE TERRAS: PRINCÍPIOS, CONCEITOS E SUA APLICAÇÃO NO BRASIL}

A política ambiental instituída pelo NCF, que promove um mercado de terras para as áreas privadas inseridas nas UCs mediante a compensação de RL por doação de área de UC de domínio público, será operacionalizada no contexto da débil governança de terras brasileira. Isso significa que os conflitos e problemas fundiários existentes no Brasil são estruturais, construídos historicamente e fazem parte do contexto de todos aspectos relacionados com a temática fundiária do país.

A compreensão da governança de terras do Brasil remete-se ao conceito mais amplo do que é a governança, tema tratado no item 4.1 deste capítulo, principalmente no intuito de utilizálo para discutir os princípios e conceitos da governança de terras, tema tratado no item 4.2. Neste item, são apresentadas as principais características da "boa governança fundiária", conforme a definição adotada pela FAO (2007), que discute o papel central desempenhado por uma adequada governança de terras para a vida social.

Esta metodologia de diagnóstico e análise da governança de terras representa o principal documento internacional normativo sobre questões fundiárias, acordado por todos os paísesmembros das Nações Unidas, abrindo um horizonte de análise sobre os instrumentos do sistema de administração de terras, que será discutido no item 4.3 deste capítulo.

Após a discussão teórica dos conceitos de governança de terras e sistema de administração de terras, inicia-se uma análise desses conceitos e princípios aplicados na gestão fundiária do Brasil, principalmente por meio dos sistemas de registro e cadastro inseridos no ambiente da governança de terras, temas tratados nos itens subsequentes.

\subsection{Governança: uma breve contextualização teórica}

O termo "governança" 25 é hoje amplamente utilizado, possuindo diversos conceitos e aplicações em diferentes contextos, seja no campo político, econômico, social, ambiental ou empresarial. Em termos genéricos, pode ser caracterizado como uma forma de gestão que

\footnotetext{
${ }^{25}$ Vale ressaltar que o conceito de governabilidade é mais amplo do que o de governança, sendo que ambos estão correlacionados. Governabilidade é baseada no apoio político para os governos e pelas instituições que sustentam um conjunto de políticas. A teoria da governança está focada em acordos, alianças e contratos elaborados pelas interações das partes interessadas, que estabelecem diferentes padrões de comportamento político. Governabilidade pode ser entendida como os acordos que dão base e condições para governar, e governança são os acordos que permitem a coordenação de um sistema que cria condições adequadas para a implementação eficiente de políticas (JACOBI; RICHARD; RIEU, [2018]).
} 
abarca desde a esfera específica local até as esferas transnacionais (JACOBI; RICHARD; RIEU, [2018]).

O termo governança possui uma classificação que permite duas abordagens: a tradicional (old or traditional governance) e a nova governança (new governance), que apontam formas de se organizar historicamente os valores das políticas públicas. Segundo Soares (2008, p. 12-13):

"Old or traditional Governance" caracteriza-se por uma abordagem em que há diferenciação regional, o poder é exercido de forma autoritária, baseado em instrumentos de comando e controle e na formulação e imposição de leis top down, assim como as decisões políticas tomadas. "New Governance" é a abordagem mais participativa, envolvendo atores públicos e privados, de forma que os processos de tomada de decisão sejam construídos numa perspectiva também bottom up. Sendo esta última abordagem melhor aplicável para enfrentar desafios ambientais de nossa época, principalmente quando relacionados ao conceito de Desenvolvimento Sustentável.

Diante das várias definições e campos de aplicações do termo governança, autores como Mayntz (2000 apud SOARES, 2008) partiram de um estudo histórico conceitual. Inicialmente o significado de governança (governance) era sinônimo de direção política. Após a década de 1970, esse termo foi consolidado como uma resposta eficaz às crises de coordenação do mercado e do Estado, que redefiniram a lógica de ação do Estado e o papel de diversos atores. As formas tradicionais de governo foram questionadas quanto à sua capacidade de coordenar as ações coletivas, bem como de enfrentar os novos desafios impostos pela complexidade dos tempos atuais e pelas rápidas mudanças no ambiente social, político, econômico, tecnológico e natural (SOARES, 2008).

Assim, as políticas baseadas no conceito de governança surgiram como alternativa a um controle hierárquico existente no âmbito das políticas nacionais e subnacionais do período do pós-guerra, principalmente para responder à necessidade de compreender e analisar algumas das transformações que estavam ocorrendo naquela época na maioria das sociedades (SOARES, 2008).

O conceito de governança entrou na agenda diante do contexto histórico das novas estruturas de política internacional com o fim da Guerra Fria, o acirramento do processo de globalização e o fracasso das políticas de reforma, que tinham sido adotadas após o fim da Segunda Guerra Mundial e no período de reconstrução imediata do pós-guerra (KOHLERKOCH, 2005 apud JACOBI; RICHARD; RIEU, [2018]).

A escolha de se trabalhar com o termo governança derivou de três fatos que foram consequências da crise do período do pós-guerra. O primeiro é que o interesse em governança surgiu como resposta à crise de paradigma nas ciências sociais, já que as disciplinas tradicionais 
refletiam a organização do século XIX. Não só as economias, os Estados e as sociedades nacionais foram desafiados como unidades de análise pela dialética da globalizaçãoregionalização, como também as análises sobre a sociedade de mercado versus o plano estatal. Assim, para os cientistas sociais, a governança tornou-se atraente por várias razões: (a) deu uma legitimidade nova para velhas práticas, (b) forneceu uma solução, embora parcial, temporária e provisória, para a crise de Estado, para o planejamento na economia mista e para a desilusão recente com as políticas neoliberais do mercado e, acima de tudo, (c) ofereceu uma solução para os problemas de coordenação política, social, econômica e ambiental que se apresentaram de forma sistêmica e complexa (JESSOP, 2003). Em segundo lugar, a expansão das práticas de governança em tantas esferas representou uma resposta a uma secular intensificação dramática de complexidade social. Como terceiro fato, filosoficamente, a governança passou a atrair a atenção como uma solução para problemas de coordenação em e entre as esferas públicas e privadas. Mesmo os economistas liberais reconhecem que o mecanismo de mercado nem sempre reflete o público fiel e/ou custos e benefícios privados de atividades econômicas. A governança considera tanto instituições formais como arranjos informais, o que implica o fortalecimento da cooperação e da resolução de conflitos entre uma multiplicidade de atores. Assim, muita importância é dada à gestão com base em noções de coordenação, participação e avaliação participativa (JESSOP, 2003).

A nova abordagem da teoria da governança também se refere aos desafios impostos pela integração europeia e pela globalização. Quanto à experiência europeia, foi observado mais nitidamente o movimento de um Estado mais intervencionista, com controles hierárquicos, para formas mais cooperativas de governança. De acordo com Jacobi, Richard e Rieu ([2018], p. 34), três tendências evidenciam formas de gestão diferentes da governança tradicional:

First, public powers play the role of resource mobilizing, incentive generation and leadership, but less and less are the full providers of collective rules and services. Second, new modes of governance are articulated through horizontal relations of interdependence among a wide range of actors: State actors, private actors and non-profit actors sharing resources and shaping relatively autonomous, informal and stable networks (Rhodes, 1996; Stoker, 1998), as it includes the participation of private actors (profit and non-profit) in policy formulation. The third aspect is that actors' types of interactions within the networks include co-operation, delegation and competition (Jessop, 1998).

Dessa forma, a governança moderna significa uma forma de governar mais cooperativa, diferente do antigo regime hierárquico, em que as autoridades estatais exerciam um poder soberano sobre os grupos e cidadãos que constituem a sociedade civil (MAYNTZ, 2001). No conceito de governança, as instituições governamentais e não governamentais, os atores públicos e privados, participam e cooperam com a formulação e aplicação das políticas. Assim, 
a estrutura da governança moderna não se caracteriza pela hierarquia, apesar de existir assimetrias de poderes, mas, sim, por diversos atores corporativos autônomos que formam redes de organizações que são interdependentes, com relações de reciprocidade, e por interações cada vez mais frequentes, em todos os tipos de limites preestabelecidos, intra e interorganizacional, intra e intersetorial, intra e internacional (RHODES, 1997 apud MAYNTZ, 2001). Para Jessop (2003, p. 101):

$[\ldots]$ governance is defined as the reflexive self-organization of independent actors involved in complex relations of reciprocal interdependence, with such self-organization being based on continuing dialogue and resource-sharing to develop mutually beneficial joint projects and to manage the contradictions and dilemmas inevitably involved in such situations. Governance organized on this basis need not entail a complete symmetry in power relations or complete equality in the distribution of benefits: indeed, it is highly unlikely to do so almost regardless of the object of governance or the "stakeholders" who actually participate in the governance process. All that is involved in this preliminary definition is the commitment on the part of those involved to reflexive self-organization in the face of complex reciprocal interdependence.

Soares (2008, p. 17), após analisar diversos autores que conceituam a governança moderna ${ }^{26}$, argumenta que:

Em todos os autores citados, mesmo com as diferenças semânticas ou de classificação, pode-se identificar que o enfraquecimento do Estado é uma das causas da necessidade de envolver os outros setores na elaboração e implementação de políticas públicas, como forma de legitimar as decisões tomadas e, ainda, que a maioria da literatura sobre o tema considera a nova, e/ou melhor, governança, a realizada através da participação e envolvimento dos interessados, da descentralização (transferência do poder para o poder local - “empowerment") [...].

As formas específicas de governança variam de acordo com a natureza do objeto de política, porém existem princípios para uma boa governança. Soares (2008, p. 16-17) define os princípios que podem servir para estabelecer os critérios para uma boa governança:

a) Abertura e transparência: trabalhar de forma aberta implica em uma linguagem acessível para o público em geral.

b) Inclusão e comunicação: a efetividade de uma política passa por assegurar uma ampla participação. A liberdade para associar, mobilizar-se e falar são importantes fatores que devem ser garantidos.

c) Coerência e Integração: as ações e políticas devem ser coerentes, principalmente quando aumentam os desafios ambientais. A coerência abrange todas as instituições, de todos os níveis. Quanto à integração, deve-se considerar todos os usos e atores envolvidos diretamente e indiretamente.

d) Equidade e ética: todos têm o direito de melhorar a sua qualidade de vida ou manter seu bem-estar. Deve-se buscar um equilíbrio entre os diversos grupos de interesse. Atos de má-fé devem ser desconsiderados pelo direito, que deve conter valores da sociedade e normas que regulam de forma justa e imparcial.

\footnotetext{
${ }^{26}$ O texto de Jacobi, Richard e Rieu ([2018]) reúne vários conceitos de governança de acordo diferentes autores e instituições.
} 
e) Accountable: os papéis e as regras tanto do legislativo quanto do executivo devem ser claras, seja quanto às violações e responsabilidades de todos os envolvidos em todos os níveis. Além disso, as regras devem valorizar os mecanismos que asseguram soluções satisfatórias, principalmente quando os conflitos aumentarem e parecerem irreconciliáveis entre os atores.

f) Eficiência: vai além da eficiência da economia clássica, deve considerar a eficiência política, social, ambiental. Por exemplo: minimizar custos de transação.

g) Responsabilidade e sustentabilidade: as políticas devem oferecer o que é necessário, segundo as demandas, objetivos claros e impactos futuros, quando possível, avaliação segundo as experiências do passado. A responsabilidade também requer uma implementação adequada das políticas e que as decisões sejam tomadas pelas pessoas competentes. Quanto à sustentabilidade, ela impõe que as políticas devem servir aos usuários das gerações presentes e futuras.

A governança moderna somente pode emergir em países que possuem uma série de condições estruturais e institucionais prévias. Como bem afirmou Mayntz (2001, p. 3-4, grifo da autora), para que as políticas públicas estejam de acordo com as diferentes formas da governança moderna é necessário que:

La condición más general para poder desarrollar una gobernanza moderna es que el poder debe estar disperso en la sociedad, pero no de manera fragmentada e ineficiente. Las autoridades políticas tienen que ser fuertes, pero no omnipotentes. Tienen que haber sido legitimadas democráticamente, de modo que se pueda estimar que los representantes electos reflejan los intereses de todos los grupos socioeconómicos, étnicos o religiosos principales de la sociedad; sólo así se puede suponer que una legislatura y un gobierno electos actúan en el interés de todos y no en el interés de una clase dominante o un partido político. En otras palabras, las autoridades políticas deben poder ser aceptadas, de modo general, como guardianes del bienestar público. Es necesario, también, que las autoridades políticas manejen recursos suficientes como para llevar a cabo las decisiones que se tomen; tienen que ser lo suficientemente diversificadas como para responder a las diferentes necesidades de regulación y poseer especial competencia en sus campos respectivos. Para poder pasar del campo público al privado en la gobernanza moderna, tiene que existir una sociedad civil fuerte, funcionalmente diferenciada y bien organizada. [...] Pero eso no basta. Para que haya gobernanza moderna, la sociedad civil tiene que estar diferenciada funcionalmente en subsistemas, en donde organizaciones especializadas lleven a cabo las funciones económicas y sociales importantes, tales como la producción, la enseñanza, el cuidado de la salud, etc. Además, para que la gobernanza moderna sea posible, la sociedad civil tiene que estar bien organizada. Tiene que haber actores corporativos que representen diferentes intereses funcionales, así como diferentes intereses socioeconómicos, es decir organizaciones como sindicatos, asociaciones empresariales, organizaciones de proveedores de cuidados de salud, de institutos científicos o de investigación científica, y organizaciones que representen los intereses de los consumidores o valores ecológicos. [...] Para que surja la gobernanza moderna, los actores corporativos tienen que ser cada uno eficiente en su propia esfera, sin que ninguno domine a los demás, y deben cooperar en la formulación de políticas públicas, en vez de limitarse a pelear entre ellos. Estas condiciones son difíciles de alcanzar. En cierto modo, lo que se espera que produzca la gobernanza moderna es al mismo tiempo, en parte, la 
condición para su surgimiento. Incluso en las partes más desarrolladas, más democráticas y más privilegiadas del mundo, en Europa Occidental y en los Estados Unidos, la realidad no corresponde totalmente a este cuadro ideal que hemos descrito.

O conceito de governança moderna, apesar de ser amplamente utilizado, somente apresenta suas características em alguns setores da sociedade e em alguns países. A maioria das políticas públicas ainda está nos modelos da velha e tradicional governança (old and traditional governance).

Os princípios da governança moderna estão presentes no conceito da boa governança de terras. Esta se relaciona, de forma resumida, com a definição de como os direitos de posse e propriedade serão exercidos, como eles devem ser alocados dentro das sociedades e como o acesso é concedido aos direitos de utilização, controle, transferência e responsabilidades associadas.

O item subsequente conceitua a governança de terras e seus instrumentos de administração de terras, para que, seguindo esses princípios e conceitos, seja possível entender a governança de terras no Brasil.

\subsection{Governança de terras: princípios e conceitos}

O conceito de governança de terras deve sempre ser balizado pelo contexto socioeconômico e pela história específica de cada sociedade.

A FAO (apud BUENO; REYDON, 2017, p. 67) traz a relação entre as pessoas e a terra (land tenure) como "a relação, definida na forma jurídica ou consuetudinária entre pessoas, enquanto indivíduos ou grupos, com respeito à terra", estendida em sentido amplo para outros recursos naturais como a água, a flora e a fauna.

Partindo inicialmente do conceito de governança, antes de se explicitar o conceito de governança de terras, temos em Fernandes (2018, p. 40) uma síntese interessante para o presente capítulo:

Governança é o processo de governar (GROVER, 2007, p. 5), ou seja, trata do modo como a sociedade é organizada e como prioridades e interesses conflitantes são conciliados. Governança inclui tanto as instituições formais do governo quanto os arranjos informais. Outra definição trata governança como a criação, aplicação e enforcement de regras na busca de fins públicos (FEENY, 1988, p. 172) ou ainda se refere a redes interorganizacionais autorganizadas caracterizadas pela interdependência, troca de recursos, regras do jogo e uma autonomia significante em relação ao estado (RHODES, 1997, p. 15). 
Outro exemplo é a definição utilizada pela Organização das Nações Unidas (ONU) sobre boa governança: esta seria a que promove a equidade, participação, pluralismo, transparência, responsabilidade e o Estado de Direito de uma maneira que seja efetiva, eficiente e duradoura (UNITED NATIONS, [2018]).

A aplicação do termo "governança" ao objeto "terra" leva ao conceito composto de governança de terras, que é, portanto, mais específico e trata da forma como a terra e os direitos a ela são gerenciados em uma dada sociedade. Palmer et al. (2009) trabalham com uma definição de governança de terras bastante elaborada, que acabou sendo utilizada pela ONU e FAO. Nas palavras dos autores:

Land governance, by extension, concerns the rules, processes and structures through which decisions are made about the use of and control over land, the manner in which the decisions are implemented and enforced, and the way that competing interests in land are managed. It encompasses statutory, customary and religious institutions. It includes state structures such as land agencies, courts and ministries responsible for land, as well as non-statutory actors such as traditional bodies and informal agents. It covers both the legal and policy framework for land as well as traditional and informal practices that enjoy social legitimacy. Fundamentally, land governance is about power and the political economy of land. The power structure of society is reflected in the rules of land tenure; at the same time, the quality of governance can affect the distribution of power in society. Tenure is the relationship among people with respect to land and its resources. These rules define how access is granted to rights to use, control and transfer land, as well as associated responsibilities and restrictions. They develop in a manner that entrenches the power relations between and among individuals and social groups. It is no surprise, therefore, that the elites and even the middle classes have stronger forms of land tenure, while the poor and vulnerable groups have weaker, more insecure forms of tenure (PALMER et al., 2009, p. 1-2).

A importância das instituições, trazida pelo recorte da governança de terras, impulsiona para uma administração multidisciplinar que ultrapassa setores e exige uma infraestrutura institucional sustentável, para que em seus arranjos se desenvolvam capacidades e ações estratégicas implantadas e atualizadas ao longo do tempo (WILLIAMSON et al., 2010).

O arcabouço teórico da governança de terras é mais completo que a simples utilização do conceito de segurança do direito de propriedade por incluí-lo e ir além dele, dando conta de esclarecer a importância do arranjo institucional relacionado à terra em uma determinada sociedade (FERNANDES, 2018).

Nesse sentido, para a FAO (2007), uma boa governança refere-se às instituições formais que apresentem características compreensíveis na definição e clara administração dos direitos de propriedade, em mecanismos simples para identificação e transferência desses direitos, na compilação cuidadosa dos títulos e dos cadastros, além do mapeamento das propriedades e do livre acesso a essas informações. 
Baseada em análise de casos, a FAO criou as Diretrizes Voluntárias para a Governança Responsável da Terra, dos Recursos Pesqueiros e Florestais no contexto da Segurança Alimentar Nacional (DVGT), aprovadas na $38^{\mathrm{a}}$ sessão extraordinária do Comitê de Segurança Alimentar Mundial (CSA), em maio de 2012 (para a versão em português, ver FAO, 2015). Essas diretrizes representam o principal documento internacional normativo sobre questões fundiárias acordadas por todos os países-membros das Nações Unidas.

Nessas diretrizes, existem alguns referenciais que norteiam a construção de indicadores usados para uma avaliação acerca da boa governança da terra. Tais indicadores estão organizados em oito eixos e dizem respeito a: a) registro de terras; b) ordenação de terras de propriedade do Estado; c) impostos prediais e avaliação das terras; d) privatização e restituição; e) planificação do uso das terras; f) serviços profissionais; g) administração de terras e posses consuetudinárias; h) desenhos e realizações de projetos.

Originado dos debates em torno da definição de governança e seguindo os princípios do conceito de governança da terra anteriormente citados, a FAO (2007) publicou o documento Buena gobernanza en la tenencia y la administración de tierras, cujo objetivo é introduzir a discussão da governança da posse e do uso da terra numa abordagem dinâmica e comparada que possibilita acompanhar a evolução das estruturas responsáveis pelo estado das instituições que regem a terra em um dado país.

A FAO, seguindo os princípios da governança de terras, coloca referências para uma governança "tipo ideal”. Os termos "boa governança fundiária" e "débil governança" permitem a comparação entre os processos de gestão fundiária, oferecendo referências para a identificação da distância e dos obstáculos existentes entre estas duas dimensões, bem como para a proposição de políticas. Para tornar mais claro o contraste entre a governança boa e a débil, Garcia et al. (2017, p. 235) adaptaram em um quadro essas diferenças propostas diretamente pela FAO: 
Quadro 2 - A boa governança e a governança débil

\begin{tabular}{|c|c|}
\hline rnança é & A governança débil é \\
\hline $\begin{array}{l}\text { iciente, eficaz e competente: formula políticas e } \\
\text { aplica eficientemente proporcionando serviços de } \\
\text { evada qualidade. }\end{array}$ & $\begin{array}{l}\text { eficiente, ineficaz e incompetente: não formula } \\
\text { olíticas eficazes ou não presta eficientemente serviços } \\
\text { e qualidade suficiente. }\end{array}$ \\
\hline & $\begin{array}{l}\text { ão responde às necessidades: não proporciona os } \\
\text { erviços que os cidadãos desejam ou necessitam. }\end{array}$ \\
\hline $\begin{array}{l}\text { Legítima: aquelas pessoas que se encontram no } \\
\text { poder conseguiram o direito de governar através da } \\
\text { eleição de parte da sociedade mediante } \\
\text { procedimentos democráticos e podem ser } \\
\text { substituídas se os cidadãos não estão satisfeitos com } \\
\text { seu desempenho. }\end{array}$ & $\begin{array}{l}\text { Ilegítima: aqueles que se encontram no poder não foram } \\
\text { eleitos pela sociedade, nem ganharam o direito de } \\
\text { governar, mas o obtiveram mediante processos não } \\
\text { democráticos, e os cidadãos não têm capacidade de } \\
\text { removê-los do poder. }\end{array}$ \\
\hline & \\
\hline $\begin{array}{l}\text { Coerente, previsível e imparcial: os resultados que } \\
\text { derivam dos processos de governança são } \\
\text { previsíveis e estão de acordo com as leis, normas e } \\
\text { os regulamentos publicados. No caso de } \\
\text { incoerência, existe a possibilidade de retificação e } \\
\text { aplicação legal da lei por uma autoridade judicial e } \\
\text { imparcial. }\end{array}$ & $\begin{array}{l}\text { coerente, imprevisível e parcial: os resultados que } \\
\text { erivam dos processos de governança são imprevisíveis, } \\
\text { ão se ajustam a normas discerníveis, e não existe a } \\
\text { ossibilidade de retificação por uma autoridade judicial } \\
\text { ue atue com parcialidade. }\end{array}$ \\
\hline $\begin{array}{l}\text { contas, demonstra profissionalismo, } \\
\text { do às perguntas, explicando suas atuações } \\
\text { onando provas de seu funcionamento. }\end{array}$ & $\begin{array}{l}\text { não } \\
\text { oles }\end{array}$ \\
\hline $\begin{array}{r}\text { ite as } \\
\text { não }\end{array}$ & $\begin{array}{l}\text { 1do grupos particulares com a } \\
\text { lando outros, por exemplo, em }\end{array}$ \\
\hline $\begin{array}{l}\text { ável: equilibra as necessidades econômicas, } \\
\text { e ambientais das gerações presentes e }\end{array}$ & libra as neces \\
\hline $\begin{array}{l}\text { Responde às necessidades locais: situa a } \\
\text { disponibilidade dos serviços ao nível mais próximo } \\
\text { dos cidadãos, em coerência com a disponibilidade } \\
\text { eficiente e eficaz em função dos custos. }\end{array}$ & $\begin{array}{l}\text { cais: não presta atenção } \\
\text { momento de dispor dos }\end{array}$ \\
\hline $\begin{array}{l}\text { rnança mediante a cric } \\
\text { sociedade civil sem re } \\
\text { municação e sobre a lil } \\
\text { ociação. }\end{array}$ & $\begin{array}{l}\text { xclusiva: exclui os } \\
\text { overnança com restriçõe } \\
\text { sobre a liberdade de ex }\end{array}$ \\
\hline $\begin{array}{l}\text { Oferecer segurança e estabilidade: oferece } \\
\text { segurança de meios de vida, livra do crime e da } \\
\text { intolerância, fornece segurança frente aos conflitos }\end{array}$ & $\begin{array}{l}\text { tabilidade: os cidadãos não podem recorrer } \\
\text { ara sua segurança, e o governo pode ser } \mathrm{i}\end{array}$ \\
\hline $\begin{array}{l}\text { Dedicação à integridade: os funcionários } \\
\text { desempenham suas funções diligente e } \\
\text { objetivamente, sem pretender subornos, e oferecem } \\
\text { assessorias e justiça independentes; o governo } \\
\text { respeita a confidencialidade. Existe uma clara } \\
\text { separação entre os interesses privados dos } \\
\text { funcionários e dos políticos, das atividades do } \\
\text { governo. }\end{array}$ & $\begin{array}{l}\text { Apoia a corrupção: os funcionários são subornados para } \\
\text { que não façam o que os cidadãos têm direito de esperar. } \\
\text { Estes distorcem as decisões em favor daqueles que os } \\
\text { recompensem e fazem uso da informação confidencial } \\
\text { para seu próprio proveito. Os funcionários e os políticos } \\
\text { utilizam o governo como meio para satisfazer seus } \\
\text { próprios interesses privados. }\end{array}$ \\
\hline
\end{tabular}

Fonte: Garcia et al. (2017, p. 235). 
Como se pode notar, os princípios da boa governança equiparam-se com os princípios da governança moderna discutida no item 4.1 deste capítulo, mostrando que esses conceitos são, antes de tudo, um compromisso ético-valorativo baseado na eficiência, responsabilidade e transparência da governança. É por essa razão que a boa governança enfatiza o papel essencial da participação social nos processos de gestão, bem como a criação de controles externos que sirvam como contrapeso ao poder autorizado aos agentes públicos.

De acordo com o documento da FAO (2007), a "governança débil" produz um conjunto de impactos negativos sobre a sociedade, pois: (a) prejudica os segmentos sociais mais pobres e vulneráveis, incapazes de pagar pelo acesso ao sistema legal e jurídico necessário para proteger seus direitos sobre a terra; (b) constitui também obstáculo ao desenvolvimento econômico, porque encarece - principalmente pela cobrança de suborno e propinas - o investimento, reduzindo a poupança e enfraquecendo a capacidade empreendedora dos vários atores sociais; (c) estimula a degradação do meio-ambiente; (d) reduz a capacidade de arrecadação fiscal proveniente da gestão da terra por parte do Estado; (e) gera insegurança jurídica aos possuidores de terra, porque seus direitos reais de uso não estão garantidos e podem ser questionados a qualquer momento, em geral por problemas vinculados aos sistemas de registro da propriedade fundiária e à sua gestão; (f) favorece os conflitos de terra e o dissipar de recursos e energia humanos, já que as falhas nos registros de propriedade e a gestão fundiária fragilizam a crença no sistema político e jurídico, estimulando a violência como método de resolução de disputas; (g) fragiliza e distorce o funcionamento dos mercados de terra e do sistema de crédito fundiário ao elevar substancialmente os custos de transação envolvidos no comércio de terra; (h) a governança débil também produz efeitos corrosivos sobre a ética e o comportamento social, pois a observação de que a corrupção beneficia aqueles que a promovem e não pune aqueles que são flagrados praticando-a generaliza a crença na eficácia de e/ou a tolerância ante comportamentos oportunistas; (i) por fim, favorece o abuso nos processos sociais que exigem, para fins de interesse social, a expropriação de terras, porque a expropriação pode constituir um instrumento poderoso de autoenriquecimento em situações de corrupção generalizada.

Essa metodologia de análise desenvolvida pela FAO permite uma avaliação da governança de terras e do sistema de administração de terras. No documento da FAO, existe uma diferenciação entre governança da terra e sistema de administração de terras.

A governança fundiária incorpora uma dimensão valorativa vinculada ao manejo dos instrumentos na busca da sustentabilidade socioeconômica e ambiental da terra, pois "la gobernanza se ocupa de los procesos mediante los cuales los ciudadanos participan em la toma 
de decisiones, los gobiernos rinden cuentas a los ciudadanos y la sociedad obliga a sus miembros a observar las normas y las leyes” (FAO, 2007, p. 7). Já a administração das terras se ocupa da dimensão instrumental/institucional da gestão das políticas fundiárias, conformando a análise de vários instrumentos para a gestão da governança de terras.

O próximo item traz os atributos instrumentais e institucionais que conformam um sistema de administração de terras para a gestão da governança de terras, para posteriormente narrar o contexto histórico em que se formou a governança de terras no Brasil e seus instrumentos de administração fundiária, em especial, o cadastro e o registro de propriedade.

\subsection{Sistema de administração de terras}

A administração de terras é o estudo de como as pessoas se organizam em torno da terra, incluindo a forma como as pessoas pensam sobre a terra e como as instituições constroem e gerenciam os processos de administração da terra (WILLIAMSON et al., 2010).

Os chamados sistemas de administração de terras, mundialmente conhecido como LAS (sigla de land administration system), são entendidos por Williamson et al. (2010, p. 453) como:

Uma infraestrutura para a implementação de políticas de terra e estratégias de gestão da terra para apoio do desenvolvimento sustentável. Tal infraestrutura inclui arranjos institucionais e um quadro processual jurídico, com vistas à informação de gestão da terra e divulgação de sistemas e tecnologias necessários para alocação e apoios aos mercados de terras, avaliação, controle de uso e desenvolvimento dos interesses do solo.

Assim, o termo "administração da terra" é usado como referência a processos de registros e consolidação de informações sobre a propriedade, valor e uso da terra e os recursos associados a estes. Tais processos são responsáveis pela determinação dos direitos sobre a terra, seu levantamento e descrição, a sua documentação e o conjunto de informações relevantes para apoio à gestão de terra.

A Figura 1, a seguir, traz a síntese contida em Williamson et al. (2010) para explicar a dinâmica de um sistema de administração de terras em que a finalidade última é rumar em direção ao desenvolvimento socioeconômico ambientalmente sustentável. Nota-se a importância de um adequado cadastro como cornerstone desta arquitetura institucional, o que capacita o funcionamento do segundo nível do esquema exposto, composto de quatro partes:

a) Registro da propriedade da parcela de terra - é a dimensão legal da propriedade da terra, onde se definem os direitos e deveres a ela associados;

b) Valor da terra - é a dimensão na qual se estabelece o valor da parcela e, a partir disso, a cobrança de tributos sobre a terra, tanto urbanos quanto rurais; 
c) Uso da terra - dimensão na qual se definem os possíveis usos da terra, urbano e rural, de preservação ou de utilização produtiva e que culturas produtivas devem ser priorizadas (zoneamento);

d) Desenvolvimento nas parcelas - regulamentação do que é permitido ou proibido nas edificações nas parcelas, a obtenção de licenças, entre outros (REYDON; FELÍCIO, 2017, p. 16-17).

Figura 1 - Perspectiva global da administração fundiária

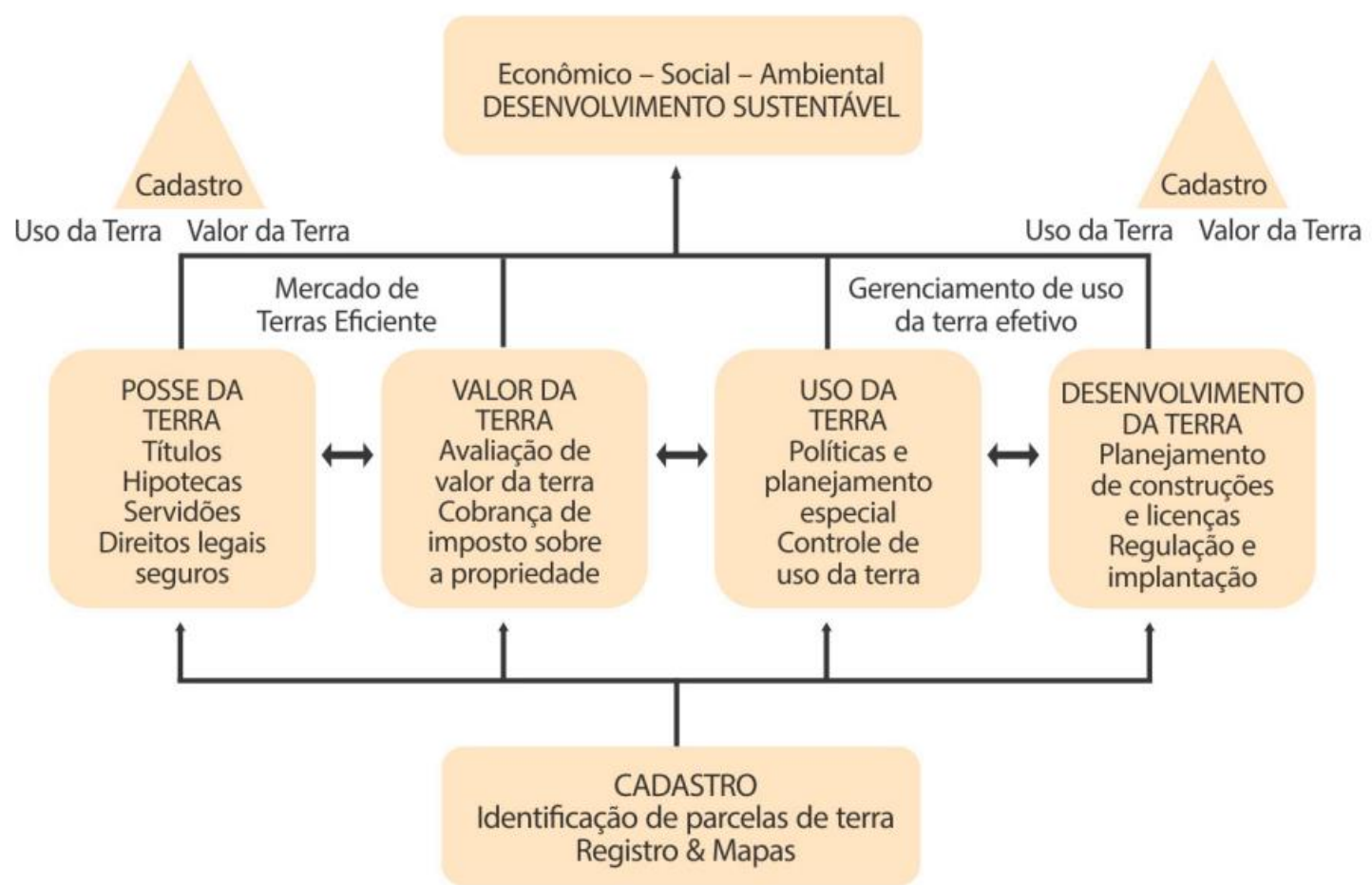

Fonte: Adaptação do esquema de Williamson et al. (2010) em Reydon e Felício (2017, p. 17).

O fundamento de um sistema de administração de terras é a garantia dos direitos de posse e propriedade, possível por meio da criação de um sistema de cadastro de terra no qual se define claramente a propriedade (limites, dimensão, localização geográfica, confrontantes, tipo de uso, dentre outros requisitos necessários) e de um sistema de registro de direitos sobre a propriedade já definida e cadastrada. Nesse sentido, reconhece-se a importância de entender melhor o sistema de cadastros e registros de terras.

\subsubsection{Sistemas de administração de terras: sistema de registro e cadastro}

Como mencionado no item anterior, um sistema de administração de terras eficiente deve incluir o registro dos imóveis (títulos de propriedades com a descrição dos direitos) e o 
cadastro (descrição, mapeamento, localização da parcela, uso e valor da parcela), devendo esse sistema ser desenhado a partir de quatro características:

1) Definição clara da parcela (posse ou propriedade); 2) Compilação e administração cuidadosa dos títulos relativos à posse e dos títulos de propriedade; 3) Mecanismos simples para identificar, atualizar e transferir direitos de posse e propriedade; 4) Transparência e acesso às informações registrais e cadastrais (BUENO; REYDON, 2017, p. 72).

O registro de terras refere-se à relação entre o sujeito e seu direito em relação à parcela, por sua vez, cadastro refere-se às relações entre a parcela, sua localização e suas características. Segundo Reydon e Felício (2017, p. 21):

O cadastro é um sistema de informação que consiste em duas partes: uma série de mapas ou planos que mostram o tamanho e a localização de todas as parcelas de terra, juntamente com informações que descrevem os atributos da terra. Distingue-se de um sistema de registro de terras, pois este último está, exclusivamente, preocupado com o direito legal associado à propriedade.

O cadastramento e mapeamento adequado das propriedades serve de instrumento de apoio principal para o registro de direitos ao garantir o bom funcionamento deste na localização das parcelas, evitando sobreposições e outros problemas. Além disso, o cadastro é o principal apoio para a tributação da terra, gestão e planejamento do território.

Bueno e Reydon (2017, p. 71) adicionam ainda que a definição de cadastro é flexível, possibilitando sua adaptação aos diversos sistemas cadastrais, já que cada país possui um sistema que reflete as características político-administrativas de sua legislação.

A ONU deixa claro que a administração fundiária requer um cadastro de terras com algumas características específicas. Segundo a ONU (1996, p. 11 apud REYDON; BUENO; SIQUEIRA, 2017, p. 128):

O cadastro é semelhante a um registro de terras na medida em que contém um conjunto de informações sobre a terra. Cadastros são baseados tanto na parcela de terra de propriedade que é a área definida pela propriedade como na área de passivo de terra que pode ser diferente da extensão da propriedade ou em áreas definidas pelo uso da terra em vez de propriedade da terra. Os cadastros podem apoiar tanto os registros de direitos de propriedade como a tributação de terra ou as informações sobre o uso da terra. O cadastro é um sistema de informações que consiste em duas partes: uma série de mapas que indicam o tamanho e a localização das parcelas de terra juntamente com registros que descrevem os atributos das mesmas. Distingue-se de um sistema de registro de terras em que seu objetivo é apenas direito de propriedade. Cadastros também podem ter um caráter multiuso para fornecer uma ampla variedade de informações relacionadas com a terra.

Outra importante definição de cadastro é dos Oficiais de Registro de Imóveis do Brasil: "Cadastro territorial é um conjunto de informações sobre o território feito pelo Executivo para viabilizar sua atuação político-administrativa na condução do Estado, orientando as políticas 
públicas com vistas ao desenvolvimento nacional" (AUGUSTO, 2013 apud REYDON; BUENO; SIQUEIRA, 2017, p. 128).

Segundo Carneiro, Erba e Augusto (2012), os principais analistas brasileiros ${ }^{27}$ do nosso sistema cadastral de imóveis entendem que o conceito internacionalmente aceito da Federação Internacional de Geômetras (FIG) define o cadastro a partir do conceito de parcelas territoriais dentro de uma determinada região administrativa, baseado no levantamento dos seus limites. Estas informações estarão organizadas metodologicamente e disponíveis ao público. Portanto o cadastro é o principal instrumento de apoio dos registros de direitos de propriedade, pois é apenas por meio do cadastramento e mapeamento que o bom funcionamento do registro é garantido, permitindo a localização das parcelas e, assim, evitando sobreposições e outros problemas.

No registro de direitos, por sua vez, deve constar a identificação completa da pessoa física ou jurídica e como esta exerce o direito sobre a terra: direitos de segurança (hipoteca, cobranças, servidões) ou direito de uso (propriedade, arrendamento, direitos de construção, usufruto, direitos consuetudinários). Um sistema de registro de propriedade significa que a não ação de registrar a transferência do direito contido na escritura ou em outro documento hábil tem como consequência jurídica a não constituição do direito de propriedade.

Assim, de acordo com Bueno e Reydon (2017), podem-se estabelecer as seguintes diferenças entre o registro e o cadastro no Brasil (Quadro 3):

\footnotetext{
${ }^{27}$ Pode-se citar como os principais: Carlos Loch, Jurgen Philips, Andrea Flavia Tenorio Carneiro, Eduardo
} Agostinho Arruda Augusto, Diogo Erba, Sérgio Jacomino e colaboradores. 
Quadro 3 - Diferenças entre registro e cadastro

\begin{tabular}{|l|l|l|}
\hline & Registro & Cadastro \\
\hline Definição & $\begin{array}{l}\text { Cuida do direito constitucional da } \\
\text { propriedade privada e dos demais } \\
\text { direitos ligados ao bem imóvel. }\end{array}$ & $\begin{array}{l}\text { Tem interesse específico de inventariar } \\
\text { dados para diferentes fins. }\end{array}$ \\
\hline Objetivo & $\begin{array}{l}\text { Sua finalidade é constituir um direito } \\
\text { legal ao indivíduo. }\end{array}$ & $\begin{array}{l}\text { Sua finalidade é político-administrativa } \\
\text { para atingir objetivos que melhorem a } \\
\text { forma de gerência estatal. }\end{array}$ \\
\hline Metodologia & $\begin{array}{l}\text { Registra os imóveis qualificados pela } \\
\text { existência de um proprietário. }\end{array}$ & $\begin{array}{l}\text { Cadastrar os imóveis e outras informações } \\
\text { associadas a ele, havendo ou não direitos } \\
\text { incidentes sobre ele. }\end{array}$ \\
\hline Execução & $\begin{array}{l}\text { Atribuição do Poder Judiciário, por } \\
\text { meio dos Cartórios de Registro de } \\
\text { Imóveis. }\end{array}$ & $\begin{array}{l}\text { Atribuição do Poder Executivo por meio } \\
\text { dos órgãos da administração fundiária. }\end{array}$ \\
\hline Legalidade & $\begin{array}{l}\text { Fornece publicidade e legalidade à à direito real ao proprietário. } \\
\text { aquisição do imóvel. }\end{array}$ & $\begin{array}{l}\text { Fornece informações consolidadas do } \\
\text { imóvel cadastrado. }\end{array}$ \\
\hline
\end{tabular}

Fonte: Bueno e Reydon (2017, p. 91).

O Quadro 3 trata das diferenças entre o registro e o cadastro. A começar pela definição, nota-se que o registro é mais amplo, tendo em vista que cuida do direito constitucional de propriedade criando direitos legais ao proprietário. Em contrapartida, o cadastro serve apenas como um banco de dados com o objetivo de auxiliar na gestão administrativa do Estado e não cria direitos legais sobre a propriedade ao indivíduo que efetuou o cadastro.

Após apresentados os conceitos de governança e de sistema de administração de terras e seus elementos principais, o cadastro e o registro das propriedades, o próximo item dedica-se a apresentar a governança e o sistema de administração de terras do Brasil.

\subsection{Governança e sistema de administração de terras no Brasil}

Para compreender o sistema de administração de terras e a dinâmica de aquisição de terras no Brasil, é necessário: 1) conhecer o papel das instituições responsáveis por confeccionar os documentos legais, como as escrituras públicas, e por registrar os direitos sobre os imóveis, que terão por objetivo determinar sua dominialidade, e 2) a relação das instituições responsáveis por registrar os direitos de domínio do imóvel com as instituições que também fazem parte da 
governança de terras, tendo os cadastros como fundamental ferramenta de gestão da administração pública.

A governança de terras do Brasil, que tem como instrumento o sistema de administração de terras, foi construída historicamente mediante um arranjo institucional confuso, burocrático, custoso e não transparente, ou seja, um arranjo que não apresenta instrumentos claros na administração dos direitos de propriedade, seja na identificação e transferências deste direito, como também na compilação cuidadosa dos títulos com o devido mapeamento e informações em seus cadastros, além do livre acesso a essas informações.

A insegurança dos direitos de propriedade no Brasil, além de afetar sua reputação internacionalmente ${ }^{28}$, contribui para a geração de graves problemas sociais, econômicos e ambientais no país. Embora existam vários custos da insegurança fundiária, Costa (2016) destaca cinco tipos de custos: conflitos e violência no campo e na cidade; ausência de mercado de arrendamento de terras; aumento do desmatamento; decisões não eficientes sobre o uso da terra; desigualdade de produtividade entre imóveis grandese pequenos ${ }^{29}$.

A insegurança dos direitos de propriedade da terra está enraizada na história do Brasile tem consequências profundas para esse país, gerando diversos conflitos e problemas fundiários, que são consequência da forma de sua ocupação territorial e da evolução dos direitos de propriedade ao longo do tempo ${ }^{30}$.

A ocupação do território brasileiro foi bastante desordenada, sem controle pelo poder público e sem a adequada separação entre as terras públicas e privadas. A forma de produzir, com baixa incorporação de progresso técnico à atividade de base agrária diante de um território amplo e acessível para o qual os posseiros e proprietários se dirigiam, dele se apossando, e a constante possibilidade de regularização dessas posses, mediante usucapião e políticas públicas, somados às fraudes no registro de Cartório de Imóveis são fatos que ainda estão presentes na realidade brasileira (REYDON, 2007; REYDON; FERNANDES; TELLES, 2015; BUENO; REYDON, 2017).

Enquanto a legislação fundiária impunha restrições ao acesso à terra, até meados do século XX, quando o país começou a adotar políticas fundiárias mais abrangentes e inclusivas,

\footnotetext{
${ }^{28}$ Em comparação a grande parte do mundo em relação à proteção dos direitos de propriedade da terra, o Brasil ocupou o $64^{\circ}$ lugar no Índice Internacional de Direitos de Propriedade (IIDP), ficando em situação ainda pior, ocupando $95^{\circ}$ posição no ranking de direitos de propriedade, no Índice de Competitividade Global do Fórum Econômico Mundial (COSTA, 2016, p. 1).

${ }^{29}$ Para mais informações sobre os custos da insegurança dos direitos de propriedade no Brasil, vide Costa (2016).

${ }^{30}$ Reydon (2007), Chiavari et al. (2016), Damasceno, Chiavari e Lopes (2017), Bueno e Reydon (2017) e Costa Neto (2018) analisaram a evolução histórica da legislação fundiária brasileira, desde o período das sesmarias até os dias atuais, mostrando os principais fatos jurídicos que caracterizam a debilidade da governança fundiária no Brasil.
} 
vastas extensões do território foram e ainda hoje são ocupadas à revelia da lei, pelo simples apossamento da terra, criando um imenso território no país à margem do direito de propriedade, mas com o direito à posse (REYDON, 2007; REYDON; FERNANDES; TELLES, 2015). Enfim, no Brasil, por razões históricas, a aquisição de imóveis rurais também se deu pela simples ocupação da terra, sem que esta ocupação tenha se transformado em uma propriedade plena.

A posse causa um descontrole na administração das terras pelo fato de estar regulada como direito sem que, contudo, exista uma forma de controle sobre seu apossamento (REYDON, 2007; REYDON; FERNANDES; TELLES, 2015; BUENO; REYDON, 2017). A falta de controle sobre as ocupações das terras no Brasil facilitou e facilita, até os dias atuais, a apropriação ilegal de terras públicas por particulares, fenômeno conhecido por grilagem ${ }^{31}$, adicionando complexidade e irregularidade à realidade agrária brasileira.

Estes dois tipos de direitos, o direito de posse e o direito de propriedade ${ }^{32}$, coexistem simultaneamente. Embora ambos sejam aceitos pelos sistemas de cadastros brasileiros, eles têm efeitos diferentes sobre a gestão do território.

Como consequência dessa forma de ocupação do território, atualmente, as terras brasileiras não estão organizadas em um cadastro único de terras, que reúna as informações geográficas e jurídicas (entre estas, o registro de domínio dos imóveis) das propriedades e posses no Brasil. Ao contrário, o registro de terras e os cadastros são geridos sem coordenação e sem uma base cartográfica única. Também não existe um cadastro conjunto de terras públicas federais e estaduais com informações precisas e confiáveis, gerando insegurança jurídica e conflitos de terras (REYDON; BUENO; SIQUEIRA, 2017; CHIAVARI et al., 2016).

\footnotetext{
${ }^{31}$ Segundo Chiavari et al. (2016, p. 28), citando o Incra, “a expressão 'grilagem' advém de um artifício antigo utilizado para conferir a documentos novos, provenientes de terras registradas ilegalmente, a aparência de antigos. Assim, os ditos 'grileiros' colocavam os falsos documentos em uma caixa justamente com diversos grilos, vedando-a logo a seguir. Depois de algumas semanas, os documentos já apresentavam aspecto amarelado e deteriorado, o que apresentava serem mais envelhecidos do que na verdade eram".

${ }^{32}$ Segundo Bueno e Reydon (2017, p. 86-87) para se "compreender o Sistema de Registro e Cadastro vigente no Brasil, é preciso entender que o Código Civil Brasileiro (Lei no 10.406 , de 2002) reconhece outros direitos reais além da propriedade e distingue a 'posse' da 'propriedade'. Segundo essa norma, considera-se possuidor todo aquele que 'tem de fato o exercício, pleno ou não, de algum dos poderes inerentes à propriedade'. Já a propriedade é considerada um direito real sobre as coisas que atribui ao seu titular, o poder pleno de exercê-lo em face de quem quer que seja, impondo a todas as pessoas o dever de respeitar o seu exercício, embora na legislação brasileira 'posse' e 'propriedade' sejam fenômenos jurídicos autônomos. O Código Civil Brasileiro (CC) não traz a definição do que seja a propriedade, sendo a mesma incluída no rol dos direitos reais do artigo 1.225 do CC. Existe no referido código, a definição de proprietário e o possuidor de forma geral. O possuidor é conceituado no artigo 1.196 do CC: 'Considera-se possuidor todo aquele que tem de fato o exercício, pleno ou não, de algum dos poderes inerentes à propriedade'. Os direitos reais sobre bens imóveis somente são adquiridos com o registro no Cartório de Registro de Imóveis (art. 1227, do CC), ou seja, os direitos sobre a propriedade somente serão válidos e produzirão efeito depois que o título estiver registrado no órgão competente".
} 
Atualmente, a gestão das terras brasileiras ocorre por meio de diversas instituições que compartilham competências e responsabilidades na regulação dos direitos de propriedade, formando um complexo e burocrático arranjo institucional, que possui regras próprias e que carece de coordenação na sua gestão ${ }^{33}$. As diversas instituições e instâncias do governo responsáveis pela governança de terras do Brasil realizam suas políticas de gestão de terras sem uma base de dados integrada com informações das terras públicas e privadas e, por não possuírem instrumentos de gestão compartilhados e não se comunicarem entre si, sobrepõem suas ações, que muitas vezes são contraditórias, gerando conflitos na gestão fundiária (REYDON et al., 2017; COSTA, 2016; DAMASCENO; CHIAVARI; LOPES, 2017).

No Brasil, a propriedade nasce com o registro público do bem. Nesse sentido, o registro de um bem imóvel no Cartório de Registro Geral de Imóveis ${ }^{34}$ é requisito fundamental para a própria constituição do direito de propriedade ${ }^{35}$. A propriedade também só pode ser transferida com a transcrição do título de transferência (como um contrato de compra e venda) no Cartório de Registro Geral de Imóveis (BUENO; REYDON, 2017, p. 88; CHIAVARI et al., 2016).

Para que um indivíduo venda, aliene ou transfira o domínio de um imóvel, dentro dos parâmetros previstos em lei brasileira, é necessário que ele realize vários procedimentos que envolvem alguns entes responsáveis por imprimir legalidade e publicidade ao ato (BUENO; REYDON, 2017, p. 88). Todas as propriedades, sejam públicas ou privadas, devem ser registradas segundo a legislação nacional ${ }^{36}$.

Ainda que esse procedimento seja considerado necessário por lei para a aquisição da propriedade, ele não vem sendo realizado em sua totalidade, podendo ser completo, no caso de direito de propriedade, entre o Tabelionato de Notas ${ }^{37}$, o registro de imóveis e os sistemas de

\footnotetext{
${ }^{33}$ Reydon et al. (2017) faz uma ampla análise do arranjo institucional da governança de terras do Brasil. Costa (2016) também menciona as diversas instituições responsáveis pela gestão e administração das terras brasileiras.

${ }^{34}$ O Cartório de Registro de Imóveis é o local onde é efetuado o registro da escritura pública e de outros títulos previstos no artigo 221, da Lei de Registros Públicos de 1973, onde o domínio é transferido e cujo título, ou seja, a matrícula vale como comprovação de propriedade. Segundo a Lei $\mathrm{n}^{\circ} 6.015 / 73$, registro é o meio hábil à comprovação do direito de propriedade e também a forma pela qual é feita a transferência dos bens imóveis (BUENO; REYDON, 2017, p. 89)

${ }^{35} \mathrm{O}$ registro geral foi instituído em 1864 , pela Lei $\mathrm{n}^{\circ} 1.237$, que estabeleceu a necessidade de registro das posses e das propriedades em cartório. Somente com a adoção do Código Civil de 1916 (Lei nº 3.071/1916), o registro público passou a ser requisito essencial para a constituição e transmissão dos direitos de propriedade. De acordo com essa lei, a propriedade só poderia ser adquirida com a transcrição do título de transferência no Registro Geral de Imóveis. Esta regra jurídica foi mantida pelo novo Código Civil, instituído pela Lei nº 10.460/2002 (CHIAVARI et al., 2016; BUENO; REYDON, 2017, p. 76).

${ }^{36}$ Com a edição da Lei n ${ }^{\circ} 6.015 / 73$, todos os bens privados e públicos devem ser registrados no Cartório de Registro de Imóveis (BUENO; REYDON, 2017).

${ }^{37} \mathrm{O}$ Tabelionato de Notas é o local onde são lavradas as escrituras públicas (documentos em que estão descritas as manifestações de vontade do proprietário ou possuidor de um imóvel) por agentes públicos. As escrituras devem ser registradas no Cartório de Imóveis e são necessárias para transmitir a propriedade desse bem ou para servir de
} 
cadastros fundiários ou permanecer na esfera da posse, quando o título ou atos constitutivos de direitos não são registrados no Cartório de Registro de Imóveis. Tanto a posse como o título de propriedade do imóvel podem, ou não, ser cadastrados por autodeclaração de seus posseiros e proprietários nos cadastros, por exemplo, no Sistema Nacional de Cadastro Rural (SNCR), que é de responsabilidade do Incra, e no CAR, que é de responsabilidade do Ministério do Meio Ambiente (MMA).

Há muitas transações imobiliárias que não são levadas a registro devido à lenta burocracia e ao elevado custo do procedimento.

No sistema de administração das terras brasileiras, existe um desacordo entre a obrigação legal de registrar a escritura e o costume de não fazer o registro. Há um conflito entre o Tabelionato de Notas, onde somente se registra o contrato de compra e venda ${ }^{38}$, e o Cartório de Registro de Imóveis. Sem o registro do contrato de compra e venda no Cartório de Registro de Imóveis, presume-se que o vendedor continue detendo a propriedade do imóvel, causando prejuízos ao comprador.

No Brasil, o registro de propriedades existente no Cartório de Registro de Imóveis, muitas vezes, não éconfiável. Segundo Costa (2016), são diversas as limitações existentes para que ocorra a fragilidade nos registros de propriedade. São elas:

[...] os cartórios, frequentemente, têm dificuldades para integrar seus registros com as entidades públicas relacionadas aos direitos de propriedade. Além disso, as estruturas de incentivo para estas instituições não estimulam a geração de um registro competente dos direitos de propriedade, já que as taxas cobradas são baseadas no número total de inscrições efetuadas, independentemente da veracidade da informação contida no registro. Por fim, a fiscalização dos serviços cartoriais é geralmente limitada. Um segundo desafio com o registro de imóveis é que ele é incompleto e desatualizado. Compradores de imóveis são obrigados por lei a registrarem seus títulos de compra, porém muitos não o fazem. Os motivos variam e podem incluir, simplesmente, inércia. As taxas elevadas também contribuem para desencorajar os proprietários de registrar transferências e outras transações. É igualmente provável que isso os incentive a declarar um valor mais baixo de suas propriedades, a fim de reduzir as taxas a pagar. [...] Outro problema é que, comumente, o registro de imóveis não possui dados de georreferenciamento das propriedades que monitora. Até pouco tempo atrás, a localização das propriedades incluídas nos registros era meramente descritiva, não incluindo mapas ou outras informações espaciais. Isto levou a uma duplicação das declarações e a um problema persistente de falsas declarações. A legislação recente exige o georreferenciamento de todos os bens, e o número de registros que possuem esses dados está crescendo.

título para comprovar a posse sobre um imóvel, quando da ação de usucapião no poder judiciário (BUENO; REYDON, 2017, p. 88).

${ }^{38}$ Ressalta-se que uma escritura pode ser lavrada em qualquer Tabelionato de Notas do país, não havendo obrigatoriedade de fazê-la na mesma cidade onde se localiza o imóvel (BUENO; REYDON, 2017). 
Entretanto, um banco de dados completo e confiável ainda não existe (COSTA, 2016, p.12).

O registro de documentos falsos no sistema é outro obstáculo comum. Isso acontece porque nem sempre os cartórios verificam corretamente a autenticidade dos documentos utilizados para registrar as propriedades privadas, por falta de capacidade ou corrupção. O problema é ainda agravado pelo fato de que, quando um cartório registra um documento falsificado, ele automaticamente dá legitimidade à declaração em qualquer local do país. Os falsificadores, então, se aproveitam disso (COSTA, 2016, p. 14).

Todos esses expedientes ocasionam e demonstram a fragilidade do atual sistema de registros de imóveis ${ }^{39}$ e de cadastros do Brasil, que abrem possibilidades de grilagem de terras ${ }^{40}$.

Diante do contexto em que os cartórios - que são entidades privadas que prestam uma função pública por delegação de registrar as terras privadas - exercem essa função sem nenhuma integração com os demais órgãos públicos, fica prejudicada a integração, comunicação e troca de informações entre o Cartório de Registro de Imóveis, o arranjo institucional da governança de terras do país e, principalmente, entre o sistema de cadastramento de terras.

As inconsistências da governança de terras no Brasil são advindas dessa fragilidade, que possibilita que imóveis de posseiros e de proprietários sejam cadastrados simplesmente por meio de um número com a informação literal descritiva, ou seja, sem informação gráfica que delimite fisicamente a área e sem integração com o sistema de registro. A falta de integração entre registro e cadastro impossibilita a identificação geográfica do imóvel e, consequentemente, a existência de um cadastro eficiente, pois os dados literais não coincidem com os dados geográficos e podem conter sobreposições de direitos (direito de posse sobreposto ao de propriedade) com sobreposição de áreas.

\footnotetext{
${ }^{39}$ Segundo o Banco Mundial (GARCIA et al., 2017, p. 239), a cobertura do registro de imóveis é muito incompleta e desatualizada. No Pará, menos de 50\% das propriedades urbanas individuais, segundo consta, são formalmente registradas, ao passo que, no Piauí e em São Paulo, calcula-se que sejam menos de 70\%. Todos os três estados indicaram que menos de $50 \%$ dos registros de terras privadas inscritas no registro são prontamente identificáveis nos mapas do registro ou do cadastro. Mesmo quando as propriedades são registradas nos cartórios presentes em cada município ou circunscrição imobiliária, os cartórios não investigam a informação nem os documentos usados para registrar propriedades privadas. Além disso, a informação em seus registros não é consolidada, o que levanta muitas questões de confiabilidade e torna quase impossível acessar informação sobre o número e a área de propriedades registradas e posse de terras em uma determinada localidade.

${ }^{40}$ Segundo Costa (2016, p. 15), em 1999, o Incra publicou “Livro Branco da Grilagem de Terras”. Naquela época, o total de terras sob suspeita de ocupação ilegal em todo o país era de aproximadamente 100 milhões de hectares, que correspondem a quatro vezes a área do estado de São Paulo. A proporção é especialmente preocupante na região Norte, onde foi estimado que 55 dos 157 milhões de hectares no estado do Amazonas sejam "grilados". Em 2006, por exemplo, um estudo apontou que mais de 30 milhões de hectares foram grilados no Pará, o que equivale a 23\% do território do estado (IPAM, 2006 apud COSTA, 2016). Mais recentemente, em 2015, um projeto piloto de digitalização de todos os documentos relacionados com cadastro e registro de terras no Pará mostrou que, em um dado munícipio, 8 milhões de hectares de terra constavam dos registros. No entanto, a área total do município é de apenas 997 mil (DAMASCENO; CHIAVARI; LOPES, 2017, p. 24).
} 
Esta fragilidade entre o sistema de cadastros e o de registros repercute em diversas fraudes existentes na gestão e no mercado de terras que impedem que as políticas públicas sejam eficientes e eficazes.

Somente no ano de 2001, com a Lei $\mathrm{n}^{\circ}$ 10.267, estabeleceu-se que os imóveis rurais devem ter seus limites georreferenciados para fins de efetivação do registro no Cartório de Registro de Imóveis, instituindo um intercâmbio sistemático de informações entre o cadastro e o registro de imóveis (BUENO; REYDON, 2017). Essa norma criou o CNIR, que integrará, inicialmente, as bases de dados do SNCR e do Cadastro de Imóveis Rurais (Cafir) e, posteriormente, as bases próprias de instituições públicas federais e estaduais. Essa lei determinou a obrigatoriedade de atualização do cadastro sempre que houver alteração nos imóveis rurais, o georreferenciamento ${ }^{41}$ (de acordo com o Sistema Geodésico Brasileiro) e, ainda, o intercâmbio mensal de informações entre os serviços do Cartório de Registro de Imóveis e o Incra, promovendo uma integração entre o registro e o cadastro. Dessa forma, a lei prevê a necessidade de compartilhamento de informações dos imóveis com o Incra e a Receita Federal em qualquer alteração do registro do imóvel (FERNANDES; REYDON, 2017, p. 59).

A ferramenta utilizada para alcançar a certificação dos imóveis é o Sigef, o qual será tratado no item específico sobre cadastro.

É a primeira vez que um cadastro fundiário brasileiro vai contemplar a informação geoespacial do imóvel rural, com a obrigatoriedade de georreferenciar a área para adequá-la à informação contida no Cartório de Registro de Imóveis. Essa troca de informações formará uma base conjunta que proporcionará maior segurança jurídica, por meio da atualização permanente das informações cadastrais e registrais. Esse instituto legal serve apenas para os imóveis que já possuem título de domínio/matrícula, sendo que esse número habilita o cadastro do imóvel rural no Sigef.

A Lei ${ }^{\circ}$ 10.267, de 2001, é a semente de um sistema de administração de terras que poderá, a partir desta legislação, unificar todas as instituições e os sistemas de registros com o de cadastros no Brasil.

Os próximos itens tratam, mais especificamente, sobre os cadastros temáticos e o cadastro fundiário sob responsabilidade do Incra e suas instituições no Brasil.

\footnotetext{
${ }^{41}$ O Decreto $n^{\circ}$ 4.449/2002, que regulamenta a Lei do Georreferenciamento, prevê um amplo intercâmbio de informações entre o CNIR e o registro de imóveis (CHIAVARI et al., 2016).
} 


\subsubsection{Sistema de cadastros no Brasil ${ }^{42}$}

Historicamente o poder público nunca conseguiu manter um cadastro atualizado, com dados precisos de suas terras, que abranja a totalidade de seu território, com informações geográficas reunidas em uma base cartográfica única. Isso ocorreu porque o país foi se desenvolvendo ao mesmo tempo que a legislação inaugurava regras sobre o uso da terra, necessitando criar diversos cadastros para atender aos diferentes propósitos da gestão fundiária (DAMASCENO; CHIAVARI; LOPES, 2017; REYDON; BUENO; SIQUEIRA, 2017).

O sistema de cadastros de terras no Brasil é bastante complexo e ineficiente, gerando sobreposições de responsabilidades, conflitos inter e intrainstitucionais, além de casos de conflitos entre órgãos de diversas esferas (estaduais vs. federais ou mesmo órgãos federais $v s$. outros órgãos federais) (REYDON; BUENO; SIQUEIRA, 2017; REYDON et al., 2017).

Atualmente existe uma multiplicidade de cadastros rurais, em geral demandando informações similares de proprietários e posseiros, que são gerenciados por diferentes instituições com responsabilidades sobrepostas (REYDON; BUENO; SIQUEIRA, 2017; REYDON et al., 2017). Vale ressaltar que existem áreas que estão fora de todo o sistema de cadastro, caso das terras devolutas ${ }^{43}$ ainda não identificadas ou discriminadas ${ }^{44}$, sujeitas a serem apropriadas privadamente por meio da posse e da grilagem de terras por particulares.

\footnotetext{
${ }^{42}$ Este item está baseado quase que integralmente no texto de Reydon, Bueno e Siqueira (2017).

${ }^{43}$ Costa (2000, p. 48-49 apud CARVALHO, 2004, p. 26) define, de acordo com a Lei de Terras (Lei ${ }^{\circ}{ }^{\circ} 601$, de 18 de setembro de 1850) em seu art. $3^{\circ}$ : "São terras devolutas: $1^{\circ}$ As que não se acharem aplicadas a algum uso público nacional, provincial, ou municipal; $2^{\circ}$ As que não se acharem no domínio particular por qualquer título legítimo, nem forem havidas por sesmarias e outras concessões do Governo Geral ou Provincial, não incursas em comisso por falta do cumprimento das condições de medição, confirmação e cultura; $3^{\circ}$ As que não se acharem dadas por sesmarias, ou outras concessões do Governo, que, apesar de incursas em comisso, forem revalidadas por esta Lei; $4^{\circ}$ As que não se acharem ocupadas por posses, que, apesar de não se fundarem em título legal, forem legitimadas por esta Lei”. Dessa forma, as terras públicas são aquelas que pertencem ao Poder Público em sentido amplo, como bens públicos. Todavia, terras devolutas são bem público em sentido restrito, com a característica essencial de em nenhum momento terem passado para o domínio particular, foram adquiridas pela União por sucessão à Coroa portuguesa e não possuem destinação específica (CARVALHO, 2004). Segundo Sidou (1995 apud ROCHA; DRUMMOND; GANEM, 2010, p. 221): "terras devolutas são 'espaços físicos que não se encontram registrados, ou se afastam do patrimônio das pessoas jurídicas públicas, administrativamente encaradas, todavia sem se incorporarem, a qualquer título, ao patrimônio de particulares"”.

${ }^{44} \mathrm{O}$ processo de discriminação de terras devolutas, conhecido também como ação discriminatória, tem como objetivo discriminar as terras devolutas, pertencentes ao Estado, das incorporadas das terras de domínio particular, de acordo com a Lei ${ }^{\circ} 6.383$ de 1976, que rege o processo de discriminação de terras devolutas da União. O Incra é o órgão responsável pela discriminação e arrecadação de terras devolutas federais, devendo, após arrecadá-las, registrá-las no Cartório de Registro de Imóveis, em seu ou da União (CARVALHO, 2004; CHIAVARI et al., 2016, p. 38). Incluem-se entre os bens do Estado as terras devolutas não pertencentes à União e os rios que tenham nascentes e foz em terras estaduais (BENATTI et al., 2008). Para Benatti et al. (2008, p. 91), "As terras devolutas se diferenciam das terras pertencentes ao patrimônio público mesmo que as duas sejam consideradas bens públicos, pois as terras devolutas são aquelas que não se acham aplicadas a algum uso público federal, estadual ou municipal, que não tenham sido legitimamente incorporadas ao domínio privado (Art. $5^{\circ}$., do Decreto-Lei $n^{\circ}$. 9.760/46). Já as terras públicas, pertencentes ao patrimônio fundiário público, são aquelas que estão inscritas e destinadas para
} 
Nenhum dos cadastros do Brasil está integrado com o registro de imóveis, com exceção dos imóveis rurais cadastrados no CNIR e/ou no SNCR que realizaram a certificação do georreferenciamento no Sigef e sua averbação na matrícula do imóvel no registro de Cartórios de Imóveis.

Os cadastros existentes no Brasil podem ser divididos em dois tipos: os fundiários e os temáticos ${ }^{45}$. Para efeito didático e até mesmo em decorrência de como está instalada a governança fundiária nacional, utiliza-se o termo cadastro fundiário como sendo o cadastro desenvolvido pelo Incra em razão da própria função legal que o órgão exerce dentro da estrutura governamental (REYDON; BUENO; SIQUEIRA, 2017). Os cadastros temáticos são aqueles que são utilizados por outros órgãos da administração pública de acordo com seus objetivos, por exemplo, objetivo fiscal, ambiental, do patrimônio da União, dentre outros, cada um com base própria de informações descritivas e gráficas. Estes, tendo em vista os órgãos responsáveis pela sua gestão, auxiliam o Incra na construção dos cadastros elencados no $\operatorname{art.~}^{\circ}$ da Lei $n^{\circ}$ 5.868/72 (REYDON; BUENO; SIQUEIRA, 2017).

Os itens a seguir iniciam a discussão sobre o SNCR. Entre os cadastros temáticos, somente serão mencionados os relacionados com o objeto desta tese, sendo eles: o CAR e o CNUC.

\subsubsection{Cadastro fundiário: Sistema Nacional de Cadastro Rural (SNCR)}

O cadastro de imóveis rurais do Incra ${ }^{46}$, o SNCR, foi criado por meio da Lei $n^{\circ} 4.504 / 64$ (Estatuto da Terra) com o objetivo de caracterizar os imóveis rurais por meio de informações sobre pessoas (proprietários, posseiros, parceiros e arrendatários), estrutura do imóvel e dados sobre uso e destinação.

\footnotetext{
algum fim, seja para preservação ambiental ou para reforma agrária". Benatti et al. (2008, p. 92) disserta que, "De acordo com a Constituição Federal, a destinação das terras devolutas deve ser compatibilizada com a política agrícola e com o plano nacional de reforma agrária (Art. 188), assim como deve servir para a proteção dos ecossistemas naturais (Art. 225, Parágrafo $5^{\circ}$.). O art. 13 da Lei ${ }^{\circ}$. 8.629, de 25 de Fevereiro de 1993, determina que as terras de domínio dos Estados devem ser destinadas, preferencialmente, à execução de planos de reforma agrária. As exceções a esta regra geral são reduzidas: criação de unidades de conservação, de projetos de pesquisa e fomento, áreas de segurança, treinamento militar, educação e defesa nacional. O órgão fundiário estadual ou federal terá plena legitimidade de trabalhar priorizando a preservação ambiental ou os assentamentos de trabalhadores rurais sem-terra, até o limite máximo de 500 ha".

${ }^{45}$ Reydon et al. (2017) analisam todos os cadastros brasileiros.

${ }^{46}$ É uma autarquia vinculada ao Ministério do Desenvolvimento Agrário que tem por objetivo executar a reforma agrária e realizar o ordenamento fundiário nacional por meio das seguintes ações: criação e implantação de assentamentos rurais sustentáveis, regularização fundiária de terras públicas, gerenciamento da estrutura fundiária do país, destinação das terras públicas, demarcação e titulação das terras ocupadas por comunidades tradicionais e quilombolas, discriminação das terras devolutas (Lei $n^{\circ}$ 6.383, de 7 de dezembro de 1976), promoção do cadastro dos imóveis rurais e certificação de georreferenciamento de imóveis rurais.
} 
Essas informações têm como objetivo servir como ferramenta para o zoneamento agrário, políticas de reforma e desenvolvimento agrário e tributação da terra (REYDON; BUENO; SIQUEIRA, 2017).

O SNCR é um sistema de cadastro que tem, de modo geral, a atribuição de cadastrar terras públicas e privadas por meio da autodeclaração dos entes públicos e privados. Dessa forma, esse cadastro abrange todos os imóveis rurais do país (REYDON; BUENO; SIQUEIRA, 2017, p. 133).

O cadastramento do imóvel rural garante ao seu titular o Certificado de Cadastro de Imóveis Rurais (CCIR), que é um documento indispensável

[...] para desmembrar, arrendar, hipotecar, vender ou prometer em venda o imóvel rural e para homologação de partilha amigável ou judicial de "sucessão causa mortis", de acordo com a Lei $n^{\circ} 4.947$, de 6 de abril de 1966, sendo essencial também para a concessão de crédito agrícola, exigido por bancos e agentes financeiros (REYDON; BUENO; SIQUEIRA, 2017, p. 133).

Conforme a lei $\mathrm{n}^{\mathrm{o}} 5.868 / 72$, art. $1^{\circ}$, o SNCR compreenderá os cinco cadastros:

I. Cadastro de Imóveis Rurais;

II. Cadastro de Proprietários e Detentores de Imóveis Rurais;

III. Cadastro de Arrendatários e Parceiros Rurais;

IV. Cadastro de Terras Públicas ${ }^{47}$;

V. Cadastro Nacional de Florestas Públicas ${ }^{48}$.

Segundo Reydon, Bueno e Siqueira (2017, p. 133), percebe-se que os cinco cadastros não foram desenvolvidos como preconiza a lei, na medida em que o cadastro de arrendatários e parceiros não existe, uma vez que nenhuma informação foi disponibilizada pelo órgão. $\mathrm{O}$ Cadastro de Imóveis Rurais é a soma dos outros três, ou seja, do Cadastro de Proprietários e Detentores de Imóveis Rurais, do Cadastro das Terras Públicas e do Cadastro Nacional das Florestas Públicas (que, em tese, deveria estar inserido no Cadastro de Terras Públicas).

\footnotetext{
${ }^{47} \mathrm{O}$ SNCR, por intermédio do Incra, possui informações sobre terras das quais a gestão pertence a outros órgãos, sendo: Fundação Nacional do Índio (Funai)/Terras Indígenas; Serviço Florestal Brasileiro/Florestas Públicas; Ministério do Desenvolvimento Agrário (MDA)/Serfal/Glebas Federais; ICMBio/UCs; MMA/CAR; Secretaria do Patrimônio da União (SPU)/Bens da União; terras rurais pertencentes aos estados/Institutos de Terras Estaduais e as terras devolutas federais e estaduais que não estão discriminadas. O SNCR gerencia, ainda, as informações de ações realizadas por ele mesmo, como as áreas quilombolas, os assentamentos rurais de reforma agrária e projetos de regularização fundiária fora da área da Amazônia Legal. Porém, na prática, segundo Reydon, Bueno e Siqueira (2017, p. 135) "[...] o SNCR deixa de cumprir sua função em razão da desarticulação entre os órgãos da administração pública federal que produzem as informações sobre terras que deveriam ser repassadas ao INCRA para o seu cadastramento no SNCR e, efetivamente, não são".

48 “O CNFP [Cadastro Nacional de Florestas Públicas] é um instrumento de planejamento da gestão florestal que reúne dados georreferenciados sobre as florestas públicas brasileiras (municipais, estaduais e federais), de modo a oferecer aos gestores públicos e à população, uma base confiável de mapas, imagens e dados com informações relevantes para a gestão florestal. O cadastro tem a missão de promover o uso econômico e sustentável das florestas e é operacionalizado pelo Serviço Florestal Brasileiro [...]" (REYDON; BUENO; SIQUEIRA, 2017, p. 136).
} 
Portanto, o Cadastro de Proprietários e Detentores de Imóveis Rurais refere-se às terras privadas (propriedades e posses) (REYDON; BUENO; SIQUEIRA, 2017, p. 134).

Ao longo dos últimos 50 anos, evidenciou-se um crescimento significativo da base cadastral do SNCR: passou-se de 3,2 milhões de imóveis e 307 milhões de hectares em 1965 para 6 milhões de imóveis e 727 milhões de hectares de área em 2015 (REYDON; BUENO; SIQUEIRA, 2017, p. 136).

No decorrer do tempo, o SNCR, apesar do crescimento da base cadastral, continua a apresentar restrições significativas, segundo os vários críticos e analistas. Segundo Reydon, Bueno e Siqueira (2017, p. 138), os principais fatores que contribuíram para a fragilidade das informações prestadas pelo sistema são:

a) O fato de o sistema não ter os dados gráficos ou geoespaciais do imóvel rural, privilegiando as informações literais, o que não possibilitou a construção de uma base fundiária;

b) Ser autodeclaratório independentemente de as informações serem válidas ou não, estando a sanção restrita a lançamento ex officio nas alíquotas máximas ( $\left(1^{\circ}\right.$, do art. $2^{\circ}$, da lei $\left.n^{\circ} 5.868 / 72\right)$;

c) Não ter tido as revisões/atualizações previstas no decreto, sendo certo que a última revisão/recadastramento foi em 1992;

d) Ainda, o caráter fiscal dos cadastros ter sido atribuído a outra instituição, a Receita Federal do Brasil (RFB), pela lei no 8.022, de 12 de abril 1990.

A fragilidade do SNCR é um reflexo da fragilidade da governança de terras do Brasil ao longo de sua história, que repercutem no sobrecadastramento ou subcadastramento e na possibilidade de cadastramento de um imóvel rural sem sua existência física, mediante fraude que é imperceptível ao sistema ${ }^{49}$.

Recentemente, com a IN Incra $n^{\circ}$ 82/2015, o SNCR foi modernizado, e os procedimentos de inscrição e atualização dos dados cadastrais passaram a ser informatizados. Com a promulgação da Lei do Georreferenciamento (Lei n ${ }^{\circ}$ 10.267/2001), o Incra tornou-se responsável pela certificação do georreferenciamento dos imóveis rurais, para garantir que os limites de determinado imóvel não se sobreponham a outros e que a realização do georreferenciamento obedeça a especificações técnicas legais (REYDON et al., 2017).

Desde 2013, o SNCR também conta com o Sigef $^{50}$, uma ferramenta eletrônica desenvolvida pelo Incra em conjunto com o Ministério do Desenvolvimento Agrário (MDA)

\footnotetext{
49 “A consequência dessa forma de operacionalização do SNCR é evidenciada quando as terras cadastradas em um município superam sua própria superfície territorial. Isso acontece quando um imóvel está cadastrado mais de uma vez ou quando há superposição de diferentes imóveis, por fraude, pela criação sistemática de municípios sem que ocorra regularização do imóvel no novo município e baixa no antigo. O sobrecadastramento e o subcadastramento fazem parte da realidade de 25\% dos municípios brasileiros" (REYDON; BUENO; SIQUEIRA, 2017, p. 138).

${ }^{50}$ Contudo os dados gráficos relativos à posse continuaram deficitários, tendo em vista que no Sigef existe a
} 
para subsidiar a governança fundiária do território nacional. O SNCR está em processo de integração ao Cafir ${ }^{51}$, para juntos formarem o CNIR. Com o Decreto $n^{\circ} 4.449 / 2002$, que regulamenta a Lei do Georreferenciamento, esta lei prevê um amplo intercâmbio de informações entre o CNIR e o registro de imóveis. Essa troca formará uma base conjunta que proporcionará maior segurança jurídica, por meio da atualização permanente das informações cadastrais e registrais (REYDON; BUENO; SIQUEIRA, 2017).

Como a implementação do CNIR ainda não se concretizou, ainda há muitas dúvidas de como essa integração será feita e se efetivamente esse novo cadastro substituirá os já existentes. Esses temas serão abordados nos itens posteriores deste capítulo.

\subsubsection{Cadastro Nacional de Imóveis Rurais (CNIR)}

A Lei $n^{\circ} 10.267 / 2001$ criou o CNIR trazendo alterações significativas na legislação fundiária. O CNIR visa a atender a necessidade de um cadastro territorial georreferenciado, servindo de base comum às diversas instituições públicas produtoras e usuárias de informações sobre o meio rural, isto é, o CNIR tem como objetivo constituir uma base comum de informações sobre o meio rural brasileiro, permitindo conhecer mais detalhadamente a estrutura fundiária (REYDON; BUENO; SIQUEIRA, 2017).

O CNIR, administrado conjuntamente pelo Incra e pela Secretaria da Receita Federal (SRF), quando finalmente implementado, deverá adotar um código único para os imóveis rurais cadastrados, para que cada um seja identificado de maneira exclusiva. O CNIR deverá integrar informações fundiárias constantes do SNCR, informações de valor fiscal presentes no Cafir e informações legais contidas nos Cartórios de Registro de Imóveis de acordo com os prazos e procedimentos estabelecidos pela Instrução Normativa Conjunta RFB/Incra $n^{\circ}$ 1.581/2015 (REYDON; BUENO; SIQUEIRA, 2017). Ou seja, as bases de dados que serão utilizadas para batimento de informações e formarão a base de dados CNIR serão: SNCR, que busca os dados gráficos do Sistema Nacional de Certificação de Imóveis (SNCI), Sigef e Cafir (RFB).

O principal ponto a ser destacado acerca da construção do CNIR é que ele prevê a integração dos cadastros, fundiário e temático, tendo como núcleo as bases de dados do SNCR e do Cafir. Contudo, como visto no item que tratou dos cadastros do SNCR, há clara falta de

\footnotetext{
informação gráfica das propriedades/matrícula, mas não das posses.

${ }^{51} \mathrm{O}$ Cafir é o Cadastro de Imóveis Rurais da SRF e reúne informações de imóveis rurais para fins tributários, sendo obrigatória essa inscrição, inclusive para aqueles que gozam de imunidade ou isenção do ITR, nos termos da IN RFB nº 1.467/2014 (CHIAVARI et al., 2016, p. 34).
} 
articulação entre os órgãos que atuam na administração fundiária e ausência de tráfego legal de informações que nutrem a bases de dados do SNCR, o que pode comprometer o funcionamento e objetivo desse cadastro geral (REYDON; BUENO; SIQUEIRA, 2017).

A primeira inconsistência apontada é acerca do conceito de parcela adotado. O CNIR definiu a parcela com base no conceito da FIG, contudo a ferramenta utilizada para obter o dado geoespacial, o Sigef, define como parcela a matrícula, uma vez que tal sistema não admite certificação da posse e necessariamente a certificação é relativa às propriedades (REYDON; BUENO; SIQUEIRA, 2017).

A lei que criou o SNCR, assim como a Lei no 10.267/2001 que criou o CNIR, prevê que a obrigatoriedade de prestar a informação acerca das terras é de cada órgão, contudo não é isso que ocorre na realidade fundiária do Brasil (REYDON; BUENO; SIQUEIRA, 2017). Além disso, não está definido na lei como e quando o CNIR integrará dados e informações de outros órgãos públicos, servindo como cadastro único para fins de planejamento agrícola, fundiário, ambiental, dentre outros (CHIAVARI et al., 2016, p. 35).

De acordo com Paixão et al. (2012, p. 263 apud CHIAVARI et al., 2016, p. 35), os principais benefícios da implementação do CNIR são: identificação de todas as terras públicas, ferramenta para a regularização fundiária e para a reforma agrária; auxílio nos processos de regularização de terras tradicionais que se sobrepõem a terras privadas; diminuição de conflitos fundiários. No entanto, os autores ressaltam que esses benefícios só serão alcançados se todas as instituições públicas colaborarem para formar um banco de dados comum, integrado e consistente.

O cadastro está em fase de implantação, tendo como ferramenta o Sigef, que vem substituindo o $\mathrm{SNCI}^{52}$ desde 2013.

\subsubsection{O Sistema de Gestão Fundiária $(\text { Sigef })^{53}$}

O Sigef é uma ferramenta eletrônica desenvolvida pelo Incra e pelo MDA para subsidiar o CNIR. Compreende uma plataforma digital na qual são efetuadas a recepção, a validação, a organização, a regularização e a disponibilização das informações georreferenciadas de limites de imóveis rurais, públicos e privados, sobre as propriedades dos imóveis (REYDON; BUENO;

\footnotetext{
52 O SNCI foi instituído no final de 2003 com o objetivo de acompanhar o monitoramento e controle de todos os processos de certificação de imóveis rurais. Nesse sistema, o proprietário elaborava o georreferenciamento da área e apresentava ao Incra ainda na forma de processo físico. Atualmente o sistema está sendo substituído pelo Sigef, que organiza o processo de certificação via digital, eletrônica (REYDON et al., 2017).

${ }^{53}$ Será realizada uma análise do Sigef no capítulo 6, que traz a metodologia e os resultados deste trabalho.
} 
SIQUEIRA, 2017). Por meio do Sigef são realizadas as certificações de dados referentes a limites de imóveis rurais realizadas via georreferenciamento $\left(\S 5^{\circ}\right.$ do art. 176 da Lei $\mathrm{n}^{\circ} 6.015$, de 31 de dezembro de 1973/art. $3^{\circ}$ da Lei $n^{\circ} 10.267 / 2001$ ) e a gestão de contratos de serviços de georreferenciamento com a administração pública.

A determinação de georreferenciamento da Lei $n^{\circ}$ 10.267, promulgada em 2001, alterou, entre outros assuntos, a Lei de Registro Público (Lei $n^{\circ}$ 6.015/73) introduzindo a exigência do georreferenciamento dos imóveis rurais. Além disso, a Lei $n^{\circ} 10.267$ exige que o polígono resultante do georreferenciamento não se sobreponha a nenhum outro já certificado pelo Incra, tal como descrito no art. 176 da citada Lei $\mathrm{n}^{\circ}$ 6.015/73.

De acordo com o art. 10 da Lei $n^{\circ} 10.267$, a identificação da área do imóvel rural, prevista nos $\S 3^{\circ}$ e $4^{\circ}$ do art. 176 da Lei $n^{\circ} 6.015$, de 1973, será exigida nos casos de desmembramento, parcelamento, remembramento e em qualquer situação de transferência de imóvel rural, na forma do art. $9^{\circ}$.

Vale ressaltar que o cadastro georreferenciado não tem prazo definido para estar completo e atualizado, ou seja, somente será exigido o georreferenciamento das áreas se existir a necessidade de atualizações no registro, como foi mencionado no art. 10 da Lei $n^{\circ}$ 10.267/2001. Para que o Brasil tenha a garantia de possuir um banco de cadastros georreferenciados completo e atualizado, é necessário que o governo federal atue de forma mais efetiva, para além da necessidade disparada pela atualização do registro.

A Lei n ${ }^{\circ} 10.267 / 2001$ também garante isenção de custos financeiros para a realização de georreferenciamento e certificação aos proprietários de imóveis rurais cuja somatória da área não exceda 4 módulos fiscais.

O sistema está funcionando desde 23 de novembro de 2013 e organiza o acervo fundiário do Incra, tendo interconexão com as áreas de interesse público da Fundação Nacional do Índio (Funai) e do ICMBio (REYDON; BUENO; SIQUEIRA, 2017). As informações coletadas pelo SNCI e Sigef ficam disponíveis no acervo fundiário do Incra.

Essa ferramenta eletrônica foi criada em substituição ao processo físico que era elaborado pelo SNCI. Neste sistema, o proprietário elaborava o georreferenciamento da área e apresentava ao Incra ainda na forma de processo físico. O instituto recebia o processo e fazia a análise dos limites e também da situação registral, ou seja, o Incra era responsável por analisar se os limites apresentados no georreferenciamento estavam corretos e se equivaliam aos descritos na matrícula (REYDON; BUENO; SIQUEIRA, 2017).

Atualmente, com o Sigef, o Incra não faz mais a análise registral de confrontação dos limites apresentados no memorial descritivo com os existentes da matrícula. Essa análise é feita 
pelo oficial de registro de imóveis que tem acesso ao Sigef, podendo conferir os dados digitalmente e emitir o comando diretamente no sistema quando estiver tudo de acordo ou deixar de fazê-lo, caso haja discrepância a ser sanada (REYDON; BUENO; SIQUEIRA, 2017).

Após a certificação dada pelo Incra, o Cartório de Registro de Imóveis inicia um processo de qualificação registral por meio da análise do oficial do cartório (REYDON; BUENO; SIQUEIRA, 2017).

Todo este processo de interligação entre os Cartórios de Registro de Imóveis e o Sigef ocorre por meio do certificado digital. Todos os cartórios do país, acessando o Sigef, podem verificar o memorial descritivo certificado pelo Incra. O memorial descritivo certificado será utilizado para retificar a matrícula do imóvel, sendo que, após a retificação, o memorial descritivo da matrícula será o mesmo memorial certificado pelo Incra, resguardando a identidade entre o memorial e a matrícula (REYDON; BUENO; SIQUEIRA, 2017).

$\mathrm{O}$ registrador somente pode proceder à averbação do georreferenciamento/memorial descritivo apresentado no Sigef mediante a apresentação de requerimento assinado pelo proprietário no Cartório de Imóveis (REYDON; BUENO; SIQUEIRA, 2017). Após a assinatura do proprietário do imóvel da averbação do memorial na matrícula registrada no cartório, este deve comunicar ao Incra pelo Sigef a conclusão do procedimento de averbação da nova descrição da área.

Para acessar o Sigef, é obrigatório ter em mãos o número da matrícula do imóvel, pois este é o número utilizado para habilitar a utilização dessa plataforma eletrônica. Uma vez que o imóvel tenha sido habilitado no Sigef, a certificação automatizada funciona da seguinte forma: 1) o responsável técnico credenciado pelo Incra faz o georreferenciamento diretamente no campo; 2) em seguida, converte as informações coletadas no campo numa planilha; 3 ) logado no Sigef com sua identificação, o responsável técnico submete a planilha ao sistema; 4) o Sigef, então, faz automaticamente a verificação das informações para identificar se há sobreposição e se estão atendidas as normas; 5) não havendo sobreposição e cumpridas as exigências, ocorre a validação do código SNCR e a validação da identificação do CPF do proprietário; 6) o imóvel está certificado, sendo emitida a planta e o memorial descritivo com os dados informados. Após esse procedimento, os Cartórios de Registro de Imóveis que estão integrados ao sistema podem conferir se os dados da certificação correspondem aos dados contidos na matrícula do imóvel (REYDON; BUENO; SIQUEIRA, 2017). Esse procedimento é chamado de qualificação registral, que dará ao interessado o direito de propriedade sobre o polígono certificado, aumentando o nível da segurança jurídica (REYDON; BUENO; SIQUEIRA, 2017). 
O memorial descritivo certificado será utilizado para retificar a matrícula do imóvel, sendo que, após a retificação, o memorial descritivo da matrícula será o mesmo memorial certificado pelo Incra, resguardando a identidade entre o memorial e a matrícula. Após a averbação do memorial, o cartório deve comunicar ao Incra pelo Sigef a conclusão do procedimento de averbação da nova descrição da área. Assim, estarão com informações gráficas e literais os imóveis que estiverem com esse procedimento completo (REYDON; BUENO; SIQUEIRA, 2017).

Após esse procedimento, as informações gráficas e literais do imóvel estão completas, ou seja, esse procedimento garante a integração na administração de terras das informações do cadastro de imóveis com as do registro de imóveis (REYDON; BUENO; SIQUEIRA, 2017). Porém, de acordo com o Decreto n ${ }^{\circ}$ 4.449/2002 e com as Normas de Execução $n^{\circ}$ 105/2012 e 107/2013, a certificação poligonal, objeto do memorial descritivo pelo Incra, não implicará reconhecimento do domínio ou exatidão dos limites e confrontações indicados pelo proprietário, ou seja, em tese, a certificação não garante dominialidade (REYDON; BUENO; SIQUEIRA, 2017).

Em outras palavras, a certificação emitida pelo Incra por meio do Sigef não registrada ou averbada na matrícula existente no registro de Cartório de Imóveis não gera direito de propriedade sobre a área certificada. Esse procedimento é similar à escritura pública de compra e venda não registrada no Cartório de Imóveis. Apesar de a lei dizer que "só é dono quem registra", o brasileiro tem o hábito de não proceder ao registro. Nesses termos, todo o esforço legal e institucional em se estabelecer um sistema de cadastro e de registro integrados pode não trazer o resultado almejado.

Os dados gerais extraídos do acervo fundiário do Incra, em 14 de julho de 2015, relativos à certificação e ao reconhecimento registral das propriedades, confirmam que, das 95.555 certificadas, apenas 5.748 foram registradas, ou seja, apenas $6 \%$ das certificações foram confirmadas pelos Cartórios de Registro de Imóveis (INCRA, 2015 apud REYDON; BUENO; SIQUEIRA, 2017). Essa informação denota que somente 6\% de todas as certificações possuem a qualificação registral, ou seja, estas estão averbadas no Sigef e correspondem às propriedades privadas. Porém, existe uma evolução das áreas certificadas no Sigef, já que os dados gráficos do acervo fundiário do Incra estão próximos de alcançar os números do SNCR, como demonstra o comparativo entre a área total do território nacional, a área cadastrada pelo Incra e a área com informações geoespaciais presente na Tabela 2. 
Tabela 2 - Comparativo de áreas cadastradas

\begin{tabular}{c|c|c}
\hline Área territorial (IBGE) & Área cadastrada (SNCR/Incra) & $\begin{array}{c}\text { Área com informações } \\
\text { geoespaciais (AFD/Incra) }\end{array}$ \\
\hline $\mathbf{8 5 1 . 5 7 6 . 7 0 5}$ ha & 601.226 .922 ha & 539.993 .774 \\
\hline $\mathbf{1 0 0 \%}$ do território & $70,6 \%$ do território & $63,41 \%$ do território nacional \\
\hline
\end{tabular}

Fonte: Incra (2014 apud REYDON; BUENO; SIQUEIRA, 2017).

A Tabela 3 traz os números gerais do acervo fundiário do Incra em 2015.

Tabela 3 - Números gerais do acervo fundiário

\begin{tabular}{|c|c|c|c|c|c|c|}
\hline \multicolumn{7}{|c|}{ Administração direta do Incra } \\
\hline Tipo & Polígonos & Área & $\begin{array}{l}\text { Certificados } \\
\text { SNCI }\end{array}$ & Área SNCI & $\begin{array}{l}\text { Certificados } \\
\text { Sigef } \\
\text { Parcelas }\end{array}$ & $\begin{array}{l}\text { Área Sigef } \\
\text { Parcelas }\end{array}$ \\
\hline Assentamentos & 7.877 & $76.669 .089,83$ & 883 & $3.793 .037,47$ & 782 & $347.989,214$ \\
\hline $\begin{array}{c}\text { Territórios } \\
\text { quilombolas }\end{array}$ & 177 & $1.870 .492,97$ & & & 6 & $1.219,9717$ \\
\hline $\begin{array}{c}\text { Certificação de } \\
\text { imóveis/parcelas } \\
\text { público }\end{array}$ & 5.816 & $71.155 .494,43$ & & & & \\
\hline $\begin{array}{c}\text { Certificação de } \\
\text { imóveis/parcelas } \\
\text { privada }\end{array}$ & 173.693 & $73.025 .987,40$ & & & & \\
\hline $\begin{array}{l}\text { Convênios de } \\
\text { regularização } \\
\text { fundiária Incra }\end{array}$ & 107.853 & $4.335 .993,96$ & & & & \\
\hline Subtotal & 295.416 & $227.057 .058,60$ & 883 & $3.793 .037,47$ & 788 & $349.209,19$ \\
\hline \multicolumn{7}{|c|}{ Acesso à base de entidades parceiras } \\
\hline Tipo & Polígonos & Área & $\begin{array}{l}\text { Certificados } \\
\text { SNCI }\end{array}$ & Área SNCI & \begin{tabular}{|l|} 
Certificados \\
Sigef \\
Parcelas \\
\end{tabular} & $\begin{array}{l}\text { Área Sigef } \\
\text { Parcelas }\end{array}$ \\
\hline Área indígena & 553 & $120.989 .725,60$ & & & & \\
\hline $\begin{array}{l}\text { Unidades de } \\
\text { conservação }\end{array}$ & 1.371 & $153.140 .480,16$ & 3 & $4.425,2526$ & 18 & $3.909,4685$ \\
\hline $\begin{array}{c}\text { Polígonos } \\
\text { georreferenciados } \\
\text { pela SRA }\end{array}$ & 80.041 & $3.254 .260,69$ & & & & \\
\hline $\begin{array}{c}\text { Polígonos } \\
\text { georreferenciados } \\
\text { pelo Terra Legal }\end{array}$ & 124.354 & $21.057 .069,43$ & & & & \\
\hline Subtotal & 206.319 & $298.441 .535,88$ & 3 & $4.425,25$ & 18 & $3.909,47$ \\
\hline Total Geral & 501.735 & $525.498 .594,48$ & 886 & $3.797 .462,72$ & 806 & $353.118,65$ \\
\hline
\end{tabular}

Fonte: Incra (2015 apud REYDON; BUENO; SIQUEIRA, 2017).

A área líquida, em hectares, no acervo fundiário é de 486.303.165,71, que equivale a $57,1 \%$ da área total do Brasil, que é de 851.576.700 hectares. 
Um dos dados da tabela anterior relevante para a análise deste trabalho é a área privada existente no ano de 2015: 73.025.987,40 ha (173.693 polígonos). A área existente no acervo fundiário de certificação dos polígonos públicos é mínima, sendo que, dos 1.371 polígonos relativos a UCs, 3 estão certificados pelo SNCI, com uma área de 4.425,2526, e 18 pelo Sigef, com uma área de 3.909,4681.

As áreas das UCs de domínio público do bioma Cerrado e as propriedades rurais certificadas organizadas neste trabalho serão discutidas no capítulo 6 deste documento.

4.4.1.4 Limitações do CNIR, do SNCR e do Sigef decorrentes da fragilidade da governança de terras do Brasil

A primeira inconsistência apontada no CNIR, no SNCR e no Sigef é o conceito de parcela adotado. Há um conceito de parcela adotado universalmente para harmonizar as diferentes conceituações das unidades contempladas nas diferentes bases cadastrais, contudo, no desenvolvimento do CNIR, esse conceito não foi utilizado (REYDON; BUENO; SIQUEIRA, 2017).

De acordo com a FIG, as parcelas são unidades de registros bem definidas por limites formais ou informais que delimitam a extensão de terra para uso exclusivo de indivíduos (famílias, sociedade ou grupos comunitários). Os limites das parcelas podem ser definidos por demarcação física sobre o terreno por uma descrição matemática, geralmente baseada em um sistema de coordenadas (REYDON; BUENO; SIQUEIRA, 2017).

O CNIR definiu parcela com base no conceito da FIG, contudo a ferramenta utilizada para obter o dado geoespacial, o Sigef, define parcela como sendo a matrícula, uma vez que o Sigef não admite certificação da posse e necessariamente a certificação é relativa às propriedades. Nota-se que há divergência do conceito de parcela dentro do próprio cadastro, pois a unidade territorial não precisa ser necessariamente a matrícula, e uma matrícula pode ser composta por várias parcelas, por exemplo, córregos, servidões administrativas etc. (REYDON; BUENO; SIQUEIRA, 2017).

Assim sendo, o novo cadastro geral já está sendo desenvolvido sem o cuidado com qualidade e precisão da informação preconizado nos princípios da boa governança de terras da FAO (2007) e da administração de terras, discutidas nos primeiros itens deste capítulo.

A base de dados do CNIR será formada pela base de dados do SNCR e do Cafir. O novo SNCR dialoga com o SNCI e Sigef para obter o dado gráfico do imóvel. O SNCI e o Sigef, por sua vez, certificam apenas as propriedades, não contemplando as áreas de posse. Como será 
possível ter um cadastro completo sem os dados gráficos da posse? O declarante da posse poderá "desenhar" sua área? Haverá confiabilidade na informação gráfica prestada pelo possuidor? Ele deverá obedecer aos mesmos critérios de georreferenciamento da certificação? Como será tratada a questão da sobreposição da posse com a propriedade no CNIR?

Vários problemas do SNCR estão relacionados à existência da posse com a propriedade, por exemplo, o sobrecadastramento. Ao que se vê, o problema será mantido no CNIR.

A base de dados CNIR está sendo desenvolvida de modo que qualquer alteração dos dados estruturais feita nessa base seja replicada nas bases do SNCR e Cafir.

Outra consequência da existência da posse com a propriedade, que fragiliza a governança de terras brasileira e reflete no Sigef, é a possibilidade de existir áreas certificadas pelo Incra na plataforma do Sigef que foram sendo griladas de posseiros que ocupam a área pacificamente por mais de cinco anos, mas não possuem nenhum documento que certifique suas posses. Em outras palavras, podem existir áreas certificadas no Sigef que são áreas griladas de posseiros que ocupam a terra há mais de cinco anos sem nenhum conflito.

Outra limitação do Sigef é que este não contempla as propriedades com menos de 4 módulos fiscais e as que possuem matrícula, mas, até os dias atuais, não precisaram realizar nenhuma alteração em seu registro, como mencionado no artigo 10 da Lei $n^{\circ}$ 10.267/2001, e não estão com suas áreas certificadas no Sigef.

Apesar dessas limitações, o CNIR, por meio do Sigef, é a única iniciativa no Brasil de integração do cadastro com o registro de imóveis no sistema de administração fundiária. Vale ressaltar também que as áreas certificadas no Sigef são aquelas que menos chances possuem de ser objetos de fraudes.

\subsubsection{Sistema Nacional de Gestão de Informações Territoriais (Sinter)}

O Sinter foi instituído por decreto em maio de 2016 pela presidente Dilma Roussef. Foi idealizado para ser um banco de dados de gestão do território nacional em uma concepção multifinalitária, ou seja, será uma plataforma de informações que poderá ser utilizada pelos vários órgãos de diferentes esferas de governo, organizando os dados territoriais, num inventário oficial e sistemático do território nacional desenvolvido com tecnologia apropriada, integrando o registro eletrônico dos Cartórios de Registro de Imóveis com o georreferenciamento do CNIR, incluindo os demais cadastros produzidos pelos órgãos, estados e municípios que irão sobrepor-se ao cadastro fundiário (art. $1^{\circ}$, Decreto $n^{\circ}$ 8.764/2016 apud REYDON; BUENO; SIQUEIRA, 2017). 
O Sinter será administrado pela Secretaria da Receita Federal do Brasil, e suas informações serão atualizadas a cada ato registral assinado, digitalmente, pelo oficial de registro.

Cada imóvel terá um identificador unívoco em âmbito nacional e com estrutura especificada no manual operacional. As informações relativas à valoração de imóveis serão consolidadas no Sinter, inclusive para subsidiar o cálculo do índice de preços de imóveis $\left(\S 2^{\circ}\right.$, art. 8, Decreto $\mathrm{n}^{\circ}$ 8.764/2016), assim como as informações estatísticas, conjunturais e estruturais relativas aos mercados mobiliário e imobiliário e aquelas relativas às garantias constituídas em operações de crédito, que serão processadas pelo Sinter em conformidade com os dados remetidos pelos serviços de registros públicos. Essas informações possibilitarão, além da Receita Federal, ao Banco Central do Brasil a consulta unificada, em âmbito nacional, das informações relativas ao crédito e ao acesso às informações necessárias ao desempenho de suas atribuições (art. 14, Decreto nº 8.764/2016).

O Sinter, ao integrar todos os cadastros de terras (ou seja, o cadastro fundiário aos demais cadastros temáticos) com as demais instituições do governo, será o sistema pelo qual serão supridas as debilidades da governança fundiária, tendo em vista que irá promover a integração e a transparência de todas informações cadastrais e dos registros dos imóveis públicos e privados do Brasil (REYDON; BUENO; SIQUEIRA, 2017).

\subsubsection{Cadastros temáticos}

Dentre os cadastros temáticos existentes - o Cafir, administrado pela Receita Federal do Brasil; o Cadastro das Terras Indígenas, sob responsabilidade da Funai; o Cadastro Nacional de Bens Imóveis de propriedade da União ${ }^{54}$, gerenciado pela Secretaria do Patrimônio da União (SPU), que é formado pelo Sistema de Administração Patrimonial (Siapa) ${ }^{55}$ e pelo Sistema de Gerenciamento do Patrimônio Imobiliário de Uso especial da União (SPIUnet) ${ }^{56}$; o Cadastro de

\footnotetext{
${ }^{54}$ Esse cadastro foi instituído pelo Decreto no $9.672 \backslash 1990$.

${ }^{55}$ O Siapa é o principal sistema da SPU e tem por objetivo fornecer funcionalidades para a gestão dos imóveis dominiais da União (terrenos de marinha, terrenos marginais, áreas de várzea federal) e permitir o controle do cadastro dos bens, das destinações vinculadas a esses imóveis, dos responsáveis vinculados a essas destinações e das receitas patrimoniais devidas.

${ }^{56}$ Este sistema mantém o cadastro de imóveis da União referente a imóveis destinados a uma finalidade específica, como as UCs e as terras indígenas, ou seja, de uso especial. Os órgãos gestores de imóveis da União são responsáveis por alimentar e atualizar o SPIUnet. Porém, ao mesmo tempo que a atualização do SPIUnet é deficitária, as diferentes bases de dados - que muitas vezes se sobrepõem - não permitem o compartilhamento de informações para a consolidação de um cadastro único que possibilite, de forma integrada, identificar as áreas sob jurisdição de cada órgão (SPU, 2008, p. 28 apud CHIAVARI et al., 2016, p. 38).
} 
Florestas Públicas ${ }^{57}$; os cadastros de cada estado federado existentes nos institutos de terras ${ }^{58}$ , somente será realizada a análise do CAR e do CNUC.

\subsubsection{Cadastro Ambiental Rural (CAR)}

O CAR é um dos instrumentos mais importantes na política prevista no NCF. Isso porque é a partir dele que todos os dados relativos às propriedades rurais, em especial sobre as APPs e RLs, poderão ser utilizados, tanto para a implementação dos demais instrumentos do novo código como para o planejamento das políticas públicas no âmbito rural.

De acordo com a base conceitual apresentada no primeiro capítulo desta tese, o CAR é o instrumento informacional e de monitoramento da política ambiental do NCF, na medida em que o CAR é um pré-requisito para a efetivação de muitos de seus instrumentos, uma ferramenta-chave para a gestão das áreas florestais inseridas nos imóveis rurais. Nesse sentido, o CAR é um instrumento indispensável para o funcionamento do NCF e vem sendo implementado independentemente por cada estado da federação.

A ideia de se criar um cadastro ambiental nas áreas rurais, como um instrumento para subsidiar para a regularização ambiental, foi originária no estado do Mato Grosso, que introduziu de forma inovadora o primeiro Sistema de Licenciamento de Propriedades Rurais (SLAPR), que previa como etapa inicial do processo de licenciamento de atividades florestais o preenchimento do CAR. Posteriormente, passou-se a adotar o CAR como condição para a emissão da Licença Ambiental Única (LAU) e para a adesão ao Programa Mato-grossense de Regularização Ambiental Rural (MT Legal) (PIRES, 2013 apud MACHADO, 2016, p. 50). Sistemas semelhantes foram implementados no estado do Pará. Os estados do Acre, Rondônia, Roraima, Amazonas e Tocantins também incorporaram o mecanismo do CAR, cada qual com sua especificidade ${ }^{59}$ (MACHADO, 2016).

Em 2007, com o Decreto n ${ }^{\circ}$ 6.321, de 21 de dezembro de 2007, foi instituído o programa Mais Ambiente, que passou a incorporar o CAR como instrumento de controle do

\footnotetext{
${ }^{57}$ Sob gestão do Serviço Florestal Brasileiro do MMA.

${ }^{58}$ Estes têm a atribuição de administrar e gerir as terras públicas, dentre elas, as terras devolutas estaduais, ou seja, aquelas não compreendidas pelo art. 64 de Constituição de 1891, que estabeleceu que pertençam aos estados as terras devolutas situadas nos seus respectivos territórios, cabendo à União somente a porção do território que for indispensável para a defesa das fronteiras, fortificações, construções militares e estradas de ferro federais, e pelo Decreto $\mathrm{n}^{\circ}$ 2.375/87.

${ }^{59}$ Pires e Savian (2016) e Machado (2016) narram a trajetória histórica do CAR.
} 
desmatamento ilegal, limitando-o, porém, ao bioma amazônico (BRASIL, 2007 apud MACHADO, 2016, p. 51).

Foi somente em $2009^{60}$ que o CAR foi expandido para todas as propriedades rurais existentes no território nacional como instrumento de regularidade ambiental (PIRES, 2013).

Incorporado como instrumento do NCF, o CAR teve poucas alterações em relação ao instrumento anteriormente previsto no programa Mais Ambiente. Um dos objetivos do cadastro é iniciar o processo de regularização ambiental das propriedades rurais do território nacional.

O CAR é um registro eletrônico de natureza declaratória e obrigatória e visa ao levantamento de informações georreferenciadas do imóvel, com delimitação das APPs, RLs, remanescentes de vegetação nativa, área rural consolidada, áreas de interesse social e de utilidade pública, para se traçar um mapa digital a partir do qual são calculados os valores das áreas para diagnóstico ambiental que mostre o perfil de ocupação do solo rural no Brasil (CAMPOS, 2017).

O Decreto $\mathrm{n}^{\mathrm{o}} 7.830 / 2012$ prevê que o CAR deverá contemplar: os dados do proprietário e/ou possuidor rural ou responsável direto pelo imóvel rural, a respectiva planta georreferenciada do perímetro do imóvel, das áreas de interesse social e das áreas de utilidade pública, com a informação da localização dos remanescentes de vegetação nativa, das APPs, das áreas de uso restrito, das áreas consolidadas e da localização das RLs (art. $5^{\circ}$ ) (CAMPOS, 2017).

De acordo com o art. $29, \S 1^{\circ}$ da Lei Federal no $12.651 / 2012$, a inscrição do imóvel rural no CAR deverá ser feita, preferencialmente, no órgão ambiental municipal ou estadual, que, nos termos do regulamento, exigirá do proprietário ou possuidor rural:

I. Identificação do proprietário ou possuidor rural;

II. Comprovação da propriedade ou posse;

III. Identificação do imóvel por meio de planta e memorial descritivo, contendo a indicação das coordenadas geográficas com pelo menos um ponto de amarração do perímetro do imóvel, informando a localização dos remanescentes de vegetação nativa, das Áreas de Preservação Permanente, das Áreas de Uso Restrito, das áreas consolidadas e, caso existente, também da localização da Reserva Legal (BRASIL, 2012).

Em que pese tratar-se de um sistema de registro nacional, a competência prioritária para inscrição de propriedades no CAR é atribuída a cada um dos estados ou municípios, nos termos do art. $29, \S 1^{\circ}$ do Código Florestal, como mencionado anteriormente. Todos os estados já possuem seus sistemas de registro do CAR devidamente interligados ao Sicar (BRASIL, 2012).

\footnotetext{
${ }^{60}$ O CAR foi previsto em legislação anterior, no Decreto $\mathrm{n}^{\mathrm{o}} 7.029 / 09$. Com a vigência do novo código passou a ser regulado pelo Decreto no 7.830/2012 (CAMPOS, 2017).
} 
De acordo com Pires e Savian (2016, p. 87):

[...] o Sistema de Cadastro Ambiental Rural (SICAR), está a cargo do Serviço Florestal Brasileiro (SFB). De acordo com o Decreto $n^{\circ} 7.830 / 2012$, o SICAR tem a função de receber, gerenciar e integrar os dados do CAR de todos os entes federados, bem como servir de plataforma direta para o cadastro dos imóveis rurais, monitorar os processos de regularização ambiental e tornar disponíveis na internet as informações de natureza pública.

O declarante tem acesso ao aplicativo, preenche o cadastro e envia ao Sicar, sendo que o envio gera um protocolo que não é inscrição, mas, sim, um número de registro (esse número é dado pelo Sicar) que é digitado na base dos dados e indica a situação do imóvel de acordo com as informações declaradas (ativo, pendente ou cancelado), ou seja, após a análise do órgão ambiental, este se manifesta acerca de pendências ou requerimentos e informações adicionais. Dependendo da informação declarada pelo posseiro ou pelo proprietário, o órgão ambiental pode suspender temporariamente ou mesmo cancelar o registro de uma determinada propriedade ou posse (MACHADO, 2016).

Dessa forma, estar inscrito no Sicar não significa que o imóvel está regular ambientalmente. Existem análises dos filtros e dos técnicos para a regularização, similar ao que ocorre com a declaração do Imposto de Renda ${ }^{61}$ (REYDON; BUENO, A. K.; BUENO, A. P., 2015).

A inscrição no CAR é condição obrigatória para o exercício de vários direitos, como: a obtenção de autorização para a supressão de vegetação nativa; o cômputo de APP nas áreas de RL; a manutenção de atividades em áreas consolidadas, entre outros (BRASIL, 2012). Da mesma forma, os benefícios que a inscrição no CAR pode trazer são: possibilidade de regularização das APPs e/ou RL; suspensão de sanções; obtenção de crédito agrícola; contratação do seguro agrícola; dedução das APPs, de RL e de uso restrito; linhas de financiamento; isenção de impostos para os principais insumos e equipamentos.

Além disso, um efetivo cadastramento ambiental vai trazer benefícios nacionalmente, que poderão proporcionar um adequado controle, monitoramento e combate ao desmatamento das florestas e demais formas de vegetação nativa, planejamento e zoneamento ambiental, para fins econômicos e de conservação, buscando maior eficiência produtiva por imóvel rural. Com isso, outros resultados adicionais à sua função primária também se tornarão possíveis, como por exemplo, o mapeamento de todas as nascentes (que ocorrem nas propriedades privadas), o mapeamento/dimensionamento dos corredores ecológicos formados, a possibilidade da

\footnotetext{
${ }^{61}$ Os declarantes não são obrigados a enviar os documentos comprobatórios, podendo o órgão competente, a qualquer tempo, solicitar o envio dos documentos, que poderão ser fornecidos por meio digital $\left(\S 4^{\circ}\right.$, do art. $7^{\circ}$, do Decreto $n^{\circ} 7.860 / 2012$ ).
} 
integração dessas áreas/informações com as UCs públicas e etc. Sem falar dos seus resultados prioritários já definidos, de mapeamento e dimensionamento das RLs, APPs, cursos e corpos d'água em todas as propriedades do país.

Ao final desse processo, será possível apontar os reais passivos existentes, tanto de RL como de APP, viabilizando o planejamento necessário para promover a adequação ambiental das propriedades rurais que possuam passivos. As regras para adequação ambiental dessas propriedades estão presentes nos PRAs. Elas foram estabelecidas em nível federal pelo Decreto $\mathrm{n}^{\circ}$ 7.830/2012 e ainda estão sendo construídas em nível estadual (CAMPOS, 2017).

Mediante as informações (qualitativas e quantitativas sobre o uso e a cobertura da terra das posses e propriedades rurais) cadastradas no CAR, será possível constituir uma base de dados para planejamento ambiental e econômico, além de apoiar e facilitar as ações de licenciamento das atividades no imóvel rural e fornecer subsídios para o planejamento da produção agropecuária, otimizar o uso das áreas sem vegetação nativa (por exemplo, estabelecer e propor ações para a conectividade de corredores) e evitar novos desmatamentos ao permitir ações estratégicas para intensificação das áreas já convertidas para o uso alternativo do solo. Outros diferenciais que podem ser associados de forma positiva ao CAR estão relacionados à melhoria da competitividade da produção rural de áreas regularizadas nos mercados externos, que a cada dia estão mais exigentes em termos de certificação ambiental ou de origem dos produtos que consomem (SAVIAN et al., 2014).

Por essas razões, o CAR é apontado por especialistas como o instrumento capaz de permitir que o poder público gerencie os recursos florestais com grande potencial, pois é um instrumento capaz de auxiliar na conciliação entre a produção agropecuária e a sustentabilidade ambiental, o qual, com o apoio das políticas públicas de desenvolvimento rural, contribuirá para redução dos desmatamentos e melhor aproveitamento das áreas de uso alternativo do solo (SAVIAN et al., 2014; MACHADO, 2016).

Segundo Machado (2016, p. 29), a partir da base de dados estabelecida pelo CAR, passa a ser possível a integração das informações autodeclaradas a fim de:

i) subsidiar as políticas fundiárias ou o planejamento de bacias hidrográficas; ii) estabelecer vínculo com os mecanismos de pagamento por serviços ambientais (PSA) e a redução das emissões por desmatamentos e degradação florestal (REDD+) em negociação no âmbito das políticas internacionais. Conforme destaca Papp (2012, p. 182): “com isso, passa-se a dispor não apenas de um instrumento de monitoramento acerca do cumprimento das obrigações da legislação ambiental, mas também - e especialmente - de uma importante ferramenta para a tomada de decisões quanto às políticas públicas de promoção do desenvolvimento sustentável". 
Se, de um lado, o CAR é um cadastro de extrema importância para a gestão das áreas florestais das propriedades e posses rurais, sendo bastante inovador e promissor, de outro, sua desvinculação dos aspectos fundiários, ou seja, da necessidade de comprovação de titulação das áreas cadastradas, vem sendo apontada como elemento de inconsistência existente nesse cadastro. Soma-se a este fato a ausência de mecanismos de controle e o cenário de incerteza atrelado ao questionamento de inconstitucionalidade de diversos dispositivos do NCF.

Conforme discutido nos itens anteriores deste capítulo, quanto mais definido o direito de propriedade, melhor será a identificação do responsável ambiental e, consequentemente, a implementação do NCF. A obrigação de cadastrar todos os imóveis rurais no CAR, com informações georreferenciadas do imóvel, esbarrou, além dos problemas ambientais, também nos fundiários.

A insegurança da propriedade brasileira, reflexo da construção histórica da governança de terras do Brasil, é o ponto principal das críticas ao CAR. Também é muito criticada a falta de integração do CAR a outras bases de dados já existentes, uma vez que esse cadastro foi criado sem nenhum plano de integração com os cadastros, principalmente com o cadastro fundiário $^{62}$ (REYDON et al., 2017; DAMASCENO; CHIAVARI; LOPES, 2017). Dessa forma, com a aprovação do NCF, os problemas fundiários tornaram-se ainda mais evidentes, e o CAR mostrou-se fundamental para que o novo código atinja seu objetivo como política ambiental.

O fato de o CAR ser autodeclaratório, em outras palavras, o fato de dar ao declarante a possibilidade de descrever seu imóvel, e sua falta de integração com o cadastro fundiário geram problemas de ordem fundiária, tendo em vista que não é atribuição do MMA operacionalizar a base fundiária.

Nesse sentido, existe a possibilidade de o declarante colocar uma base fundiária do imóvel diferente da que conste no cadastro do Incra. Essa sistemática pode comprometer o objetivo do CAR de possibilitar o planejamento ambiental e econômico do uso e ocupação do imóvel rural, devido à eventual falta de comprovação de que essa posse ou propriedade é válida, e que o posseiro ou proprietário tenha, realmente, as áreas que precisam ser, ambientalmente, declaradas.

\footnotetext{
${ }^{62}$ Vale mencionar a falta de integração entre o CAR e o Ato Declaratório Ambiental (ADA), do Ibama. As informações prestadas no CAR poderiam servir para a isenção de ITR, tal como está previsto hoje no ADA. Porém, por falta de previsão legal, ambos os cadastros ainda estão vigentes, impondo ao proprietário e ao possuidor a obrigatoriedade de prestar as mesmas informações aos diferentes órgãos (DAMASCENO; CHIAVARI; LOPES, 2017, p. 36).
} 
O fato de não ter sido prevista a obrigatoriedade de informar, no ato da inscrição, o número do imóvel rural no SNCR repercute em diversos problemas fundiários, como a sobreposição de áreas, os cadastros de títulos falsos, os cadastros de posses griladas etc.

Como observado por Barros e Barcelos (2016 apud DAMASCENO; CHIAVARI; LOPES, 2017, p. 23), o fato de o registro do CAR ser totalmente declaratório pode tornar-se uma nova fonte de fraude, grilagem. Ativistas relatam que grandes posseiros e proprietários estão utilizando documentos do CAR para afugentar populações tradicionais, fazendo-as pensar que as terras que eles ocupam têm outro proprietário legítimo.

Esta falta de registros apropriados leva a sobreposições de diferentes propriedades, o que muitas vezes resulta em conflitos. Por exemplo, a terra indígena Manoki, no Mato Grosso, vem sofrendo desmatamentos provocados por fazendeiros e madeireiras há alguns anos. Recentemente a Secretaria de Estado do Meio Ambiente (Sema) descobriu que existem 54 propriedades privadas cadastradas no CAR dentro dos limites de Manoki. Essas fazendas têm recebido financiamento de bancos públicos, bem como autorizações para remoção de vegetação (DAMASCENO; CHIAVARI; LOPES, 2017, p. 26).

A sobreposição de autodeclarações no CAR é uma realidade. O capítulo 6 traz um indicador de áreas particulares, públicas cadastradas no Sigef, assentamentos e terras indígenas que estão sobrepostas às áreas autocadastradas no CAR.

O MPF, em conjunto com outros órgãos de fiscalização, recentemente organizou a operação Rios Voadores e descobriu que o CAR estava sendo usado por "laranjas" para iniciar o processo de regularização fundiária de áreas públicas que seriam posteriormente loteadas e revendidas (CAVERNI, 2016 apud DAMASCENO; CHIAVARI; LOPES, 2017). No Pará, o MPF averiguou que uma quadrilha "esquentava" a madeira extraída ilegalmente, usando o CAR para solicitar planos de manejo florestal sustentável (BARROS; BARCELOS, 2016 apud DAMASCENO; CHIAVARI; LOPES, 2017).

Pela falta de segurança da propriedade, vários documentos são utilizados para garantir a posse e a propriedade. Embora o NCF disponha que a inscrição no CAR não será considerada para fins de reconhecimento de direito de propriedade, na prática, ela tem sido utilizada como um dos documentos para comprovar a posse nos processos de regularização fundiária e, sobretudo, também para a grilagem de terras (DAMASCENO; CHIAVARI; LOPES, 2017). Outro importante agravante é a ausência de uma ferramenta que permita uma atualização periódica dos dados referentes a cada imóvel (REYDON; BUENO; SIQUEIRA, 2017), ou seja, pode-se considerar que o CAR é estático no tempo. 
A regularidade fundiária precede a regularidade ambiental. Desse modo, o declarante do CAR somente pode fazê-lo após estar com sua situação fundiária resolvida e cadastrada no Incra.

Se houver integração com outros cadastros de uma forma apropriada, o CAR poderá ser um instrumento valioso para a definição dos direitos de propriedade em áreas onde sobreposições territoriais existem. Porém ainda não foi definida a forma como essa integração acontecerá.

A integração entre o CAR e o acervo fundiário do Incra possibilitaria maior segurança jurídica, pois o Sigef possui uma grande base de imóveis rurais com número de matrícula no Cartório de Registro de Imóveis que já foram georreferenciados e certificados de acordo com as normas técnicas de alta precisão. Essa integração, além de identificar problemas de sobreposição entre imóveis rurais, também auxiliaria a combater a grilagem de terras (TORSIANO, 2016 apud DAMASCENO; CHIAVARI; LOPES, 2017; REYDON et al., 2017; REYDON; BUENO; SIQUEIRA, 2017).

Fernandes (2018), citando diversos trabalhos, mostra que o CAR tem potencial para diminuir o desmatamento, mas somente se o problema anterior da insegurança dos direitos de propriedade for resolvido. Esse autor cita o trabalho de L'Roe et al. (2016), que realizaram um estudo aprofundado do CAR no estado brasileiro do Pará e concluíram que a participação nesse cadastro autodeclarado tem pouco impacto no desmatamento devido à insegurança dos direitos de propriedade.

Como forma de aumentar a credibilidade do CAR em relação à questão fundiária na temática ambiental, o ideal seria a construção de uma plataforma webservice que integrasse o Sigef com o CAR, já que ambos têm a necessidade de uma base cartográfica. Contudo essa opção também seria deficitária aos fins do MMA, uma que no Sigef estão as informações gráficas das propriedades e não das posses (REYDON; BUENO; SIQUEIRA, 2017).

O Serviço Florestal Brasileiro, órgão do MMA responsável pela implantação do cadastro, divulga regularmente boletins informativos sobre os dados do CAR (SFB, 2016). A Tabela 4 está disponível no site do ministério, informando os resultados obtidos até o final do mês de agosto de 2016. Apresenta-se um quadro geral da situação do cadastramento no país, por sub-região, até o momento da publicação do documento. 
Tabela 4 - Resultados do CAR de agosto de 2016

\begin{tabular}{l|r|r|r}
\hline Regiões/dados & \multicolumn{1}{|c|}{$\begin{array}{c}\text { Área } \\
\text { passível de } \\
\text { cadastro }\end{array}$} & \multicolumn{1}{c|}{$\begin{array}{c}\text { Área total } \\
\text { cadastrada }\end{array}$} & $\begin{array}{c}\text { Número de } \\
\text { imóveis } \\
\text { cadastrados }\end{array}$ \\
\hline Norte & 93.717 .515 & 133.360 .346 & 644.186 \\
\hline Nordeste & 76.074 .156 & 67.913 .451 & 1.396 .122 \\
\hline Centro-Oeste & 129.889 .570 & 126.352 .007 & 402.756 \\
\hline Sudeste & 56.374 .996 & 65.112 .041 & 1.119 .317 \\
\hline Sul & 41.780 .627 & 43.017 .879 & 1.257 .193 \\
\hline TOTAL & 397.836 .864 & 387.539 .624 & 387.539 .626 \\
\hline
\end{tabular}

Fonte: SFB (2016 apud REYDON; BUENO; SIQUEIRA, 2017).

Como se pode observar nos dados da Tabela 4, quase a totalidade das áreas passíveis de cadastro já foram cadastradas no CAR. Vale notar que em todas as regiões do Brasil, exceto Nordeste e Centro-Oeste, a área total cadastrada é maior do que a área passível de cadastro.

O prazo para todos os proprietários e posseiros de terras rurais terminarem seus cadastramentos vem sendo prorrogado via medida provisória. A primeira, MP n ${ }^{\circ} 724$, de 4 de maio de 2016, prorrogou o prazo de adesão ao CAR até 5 de maio de 2017 para os pequenos produtores. A medida visava a beneficiar os produtores com até 4 módulos fiscais. Ainda assim, menos da metade desses produtores havia aderido ao cadastro até a data limite. A segunda alteração ocorreu por meio da Lei ${ }^{\circ} 13.295$, de 14 de junho de 2016, estendendo os prazos para adesão ao CAR até 31 de dezembro de 2017 (prorrogável por mais um ano) a todos os produtores rurais. A Comissão de Meio Ambiente e Desenvolvimento Sustentável aprovou, por meio do Projeto de Lei $\mathrm{n}^{\circ} 4.550 / 16$, do deputado Heitor Schuch (PSB-RS), a prorrogação do prazo para inscrição de imóvel rural no CAR até 5 de maio de 2018. Esse projeto de lei prevê ainda nova prorrogação a critério do poder executivo ${ }^{63}$.

\subsubsection{Cadastro Nacional de Unidades de Conservação (CNUC)}

O CNUC é um sistema integrado de banco de dados com informações padronizadas das UCs geridas pelos três níveis de governo e por particulares. Ele é mantido e organizado pelo MMA com a colaboração do Ibama e dos órgãos federal, estaduais e municipais (art. 50, Lei n ${ }^{\circ}$ 9.985/2000).

\footnotetext{
${ }^{63}$ Notícia da Câmara dos Deputados, disponível em: <http://www2.camara.leg.br/camaranoticias/noticias/MEIOAMBIENTE/543177-MEIO-AMBIENTE-APROVA-PRORROGACAO-PARA-INSCRICAO-DE-IMOVELNO-CADASTRO-AMBIENTAL-RURAL.html>; acesso em: nov. 2017.
} 
Seu principal objetivo é disponibilizar um banco de dados com informações oficiais do SNUC (Tabela 5). O CNUC contém os dados principais de cada UC, incluindo, dentre outras características relevantes, informações sobre espécies ameaçadas de extinção, situação fundiária, recursos hídricos, clima, solos e aspectos socioculturais e antropológicos $\left(\S 1^{\circ}\right.$, art. 50, Lei n $\left.{ }^{\circ} 9.985 / 2000\right)$.

Tabela 5 - Tabela consolidada das UCs

\begin{tabular}{|c|c|c|c|c|}
\hline \multirow{3}{*}{$\begin{array}{l}\begin{array}{l}\text { Tabela Consolidada das } \\
\text { Unidades de Conservação }\end{array} \\
\text { Tipo/Categoria } \\
\end{array}$} & \multirow{2}{*}{\multicolumn{2}{|c|}{\begin{tabular}{|l|}
2014 \\
Federal/Estadual/Municipal \\
\end{tabular}}} & \multirow{2}{*}{\multicolumn{2}{|c|}{\begin{tabular}{|l|}
2016 \\
Federal/Estadual/Municipal \\
\end{tabular}}} \\
\hline & & & & \\
\hline & $\mathbf{N}^{\mathbf{0}}$ & Área $\left(\mathrm{Km}^{2}\right)$ & $\mathbf{N}^{\circ}$ & Área $\left(\mathrm{Km}^{2}\right)$ \\
\hline \multicolumn{5}{|l|}{ Proteção integral } \\
\hline Estação ecológica & 90 & 115.557 & 96 & 122.351 \\
\hline Monumento natural & 38 & 1.390 & 43 & 1.421 \\
\hline Parque nac./est./mun. & 350 & 347.126 & 395 & 357.533 \\
\hline Refúgio da vida silvestre & 30 & 3.735 & 40 & 3.867 \\
\hline Reserva biológica & 60 & 52.823 & 62 & 56.126 \\
\hline Total de proteção integral & 568 & 520.632 & 636 & 541.296 \\
\hline \multicolumn{5}{|l|}{ Uso sustentável } \\
\hline Parque nac./est./mun. & 104 & 300.007 & 106 & 314.130 \\
\hline Reserva extrativista & 87 & 143.443 & 90 & 144.610 \\
\hline $\begin{array}{l}\text { Reserva de desenvolvimento } \\
\text { sustentável }\end{array}$ & 34 & 110.892 & 37 & 112.153 \\
\hline Reserva de fauna & 0 & 0 & 0 & 0 \\
\hline Área de proteção ambiental & 278 & 442.771 & 302 & 464.008 \\
\hline $\begin{array}{l}\text { Área de relevante interesse } \\
\text { ecológico }\end{array}$ & 48 & 925 & 50 & 1.020 \\
\hline RPPN & 709 & 5.411 & 808 & 5.540 \\
\hline Total uso sustentável & 1.260 & 1.003 .448 & 1.393 & 1.041 .462 \\
\hline TOTAL GERAL & 1.828 & 1.524 .080 & 2.029 & 1.582 .758 \\
\hline $\begin{array}{l}\text { Área considerando } \\
\text { sobreposição mapeada }\end{array}$ & 1.828 & 1.494 .989 & 2.029 & 1.544 .159 \\
\hline
\end{tabular}

Fonte: Elaboração própria com dados do CNUC/MMA (2017 apud REYDON; BUENO; SIQUEIRA, 2017).

Observa-se na Tabela 5 que a unidade de medida utilizada é o quilômetro quadrado, e não o hectare, que é utilizado como medida nos demais cadastros do Brasil.

Muitas informações desses cadastros estão desatualizadas, por exemplo, a situação fundiária das UCs de domínio público. No capítulo 5, é citado o trabalho de Rocha, Drummond e Ganem (2010) que analisa essas informações para os parques nacionais, chegando à conclusão que elas são questionáveis e incongruentes com a realidade dessa categoria de UC. 
Concluindo, o CNUC assim como os demais cadastros do Brasil não têm interoperabilidade. Cada órgão trabalha sobre as áreas de sua competência e utiliza conceitos específicos e diversos para definir "as áreas analisadas". A maioria dos órgãos públicos não cadastra e registra suas terras como deveriam, fazendo com que o Brasil não tenha sistemas de cadastro e registro que se complementem e sejam dinâmicos, como demonstrado anteriormente. 


\section{CONSOLIDAÇÃO TERRITORIAL E A REGULARIZAÇÃo FUNDIÁRIA EM UNIDADES DE CONSERVAÇÃO DE DOMÍNIO PÚBLICO NO BRASIL: LIMITES PARA O SEU ALCANCE}

As UCs são essenciais para proteger os recursos naturais que sustentam a economia e a vida (MEDEIROS; YOUNG , 2011). Elas cumprem uma série de funções cujos benefícios são usufruídos por grande parte da população brasileira - inclusive por setores econômicos em contínuo crescimento, apesar de não internalizarem em suas atividades econômicas os custos e os benefícios dos serviços ecossistêmicos ${ }^{64}$.

A criação das UCs pelo poder público é considerada uma estratégia vital para garantir a manutenção dos recursos naturais no longo prazo. No Brasil, as UCs vêm sendo criadas, porém sua consolidação territorial, entendida como um conjunto de ações voltadas para as condições necessárias para que cumpram com seus objetivos básicos e específicos, está distante da sua realidade.

Duas ações são fundamentais para que ocorra a consolidação territorial das UCs de domínio público: regularização da situação fundiária e consolidação de limites (diagnóstico preliminar do perímetro, identificação de sobreposições, readequação dos memoriais descritivos, demarcação topográfica e sinalização de perímetro) (MMA, 2011; OLIVEIRA, 2010). A transferência de domínio das áreas que conformam as UCs para o órgão gestor, ou seja, sua regularização fundiária é fundamental, pois, sem a dominialidade definida das áreas das UCs, sua gestão, para a conservação de seus recursos naturais, fica comprometida ${ }^{65}$.

\footnotetext{
${ }^{64}$ Por se tratarem de produtos e serviços em geral de natureza pública, prestados de forma difusa, seu valor não é percebido pelos usuários, que, na maior parte dos casos, não pagam diretamente pelo seu consumo ou uso. Em outras palavras, o papel das UCs não é "facilmente internalizado" na economia nacional. Essa questão decorre, ao menos em parte, da falta de informação sistematizada que esclareça a sociedade sobre seu papel no provimento de bens e serviços que contribuem para o desenvolvimento econômico e social do país. Por exemplo, $80 \%$ da hidroeletricidade do país vem de usinas que têm pelo menos um tributário a jusante de UCs. Parte expressiva da qualidade e da quantidade da água que compõe os reservatórios de usinas hidrelétricas, provendo energia a cidades e indústrias, é assegurada por UCs. Além disso, mais de um terço da água para consumo humano é diretamente captada em UCs ou em rios que se beneficiam de sua proteção. O turismo, que dinamiza a economia de muitos dos municípios do país, só é possível pela proteção de paisagens proporcionada pela presença de UCs. O desenvolvimento de fármacos e cosméticos consumidos cotidianamente, em muitos casos, utilizam espécies protegidas por UCs. Ao mesmo tempo, as UCs contribuem de forma efetiva para enfrentar um dos grandes desafios contemporâneos, a mudança climática. Ao mitigar a emissão de $\mathrm{CO}_{2}$ e de outros gases de efeito estufa decorrentes da degradação de ecossistemas naturais, as UCs ajudam a impedir o aumento da concentração desses gases na atmosfera terrestre. Esses exemplos permitem constatar que esses espaços protegidos desempenham papel crucial na proteção de recursos estratégicos para o desenvolvimento do país, um aspecto pouco percebido pela maior parte da sociedade, incluindo tomadores de decisão, e que, adicionalmente, possibilitam enfrentar o aquecimento global (MEDEIROS; YOUNG, 2011).

${ }^{65}$ Fernandes (2018) tem como objetivo discutir os estudos que trazem impactos das intervenções relacionadas à governança de terras no meio ambiente - mais especificamente, na prevenção ou diminuição do desmatamento e
} 
Nesse sentido, este capítulo tem como objetivo discutir os elementos relacionados à questão da consolidação territorial das UCs do Brasil, com ênfase na regularização fundiária das UCs de domínio público, dada sua importância para a integralização do território e da gestão das áreas das UCs.

O mecanismo de compensação de RL por doação de área de UCs é um dos instrumentos de regularização fundiária das UCs, uma vez que cria um mercado de terras entre ofertantes de áreas inseridas nos limites das UCs e demandantes de áreas que desmataram seus recursos naturais e necessitam, dessa forma, compensar seus déficits de RL. Os alcances e limites desse instrumento serão analisados no capítulo 6 deste documento com base no estudo da região do Cerrado.

A importância da discussão trazida neste capítulo é de situar esse instrumento num horizonte mais amplo, seja relacionado à realidade fundiária das UCs, que reflete todos os conflitos e problemas existentes na governança de terras do Brasil, seja no abandono histórico dos governantes brasileiros na implementação das UCs do Brasil.

\subsection{A consolidação territorial em Unidades de Conservação de domínio público: limites para seu alcance}

Conforme discutido no item 3.1 deste trabalho, a proteção dos recursos naturais tornouse relevante com a Constituição de 1988, que a caracterizou como um direito fundamental, essencial à qualidade de vida das gerações presentes e futuras (art. 225 da Constituição). Uma das formas previstas para assegurar a efetividade desse direito é a definição: "em todas as unidades da Federação, de espaços territoriais e seus componentes a serem especialmente protegidos" (BRASIL, 1988).

melhorias na conservação e uso do solo - e cita o trabalho de diversos autores que comprovam que os direitos bem definidos de propriedade possuem uma relação direta com a conservação do meio ambienta e diminuem a taxa de desmatamento. O trabalho de Assunção et al. (2015 apud FERNANDES, 2018) mostra que, no período de 20042009, cerca de 59\% do desmatamento previsto na Amazônia foi evitado por políticas públicas, coordenadas entre vários níveis de governo, que promoveram ações para garantir a segurança aos direitos de propriedade da terra. Araujo et al. (2009 apud FERNANDES, 2018) também realizaram um estudo similar para a Floresta Amazônica brasileira e constataram que os direitos de propriedade inseguros têm impacto positivo no desmatamento no período de 1988-2000. Esses autores concluem que garantir direitos transparentes e seguros sobre a propriedades da terra poderia diminuir ou evitar desmatamento futuro. Robinson et al. (2014 apud FERNANDES, 2018) analisaram as UCs e também mostraram que a segurança dos direitos à terra (land tenure security) tem impactos significativos para se alcançar menores taxas de desmatamento nessas áreas. Nolte et al. (2013 apud FERNANDES, 2018) mostram que o principal fator para o sucesso de uma UC em atingir seu objetivo de conservação está fortemente associado à ausência de conflitos em relação aos direitos de propriedade de suas terras. $\mathrm{O}$ autores ainda afirmaram que todos os regimes de governança de áreas protegidas ajudaram a reduzir o desmatamento. 
A criação de UCs é considerada uma das melhores estratégias para a conservação da biodiversidade in situ (MEDEIROS; YOUNG, 2011). No Brasil, foi com a criação do SNUC (Lei $\mathrm{n}^{\circ}$ 9.985/2000, regulamentada pelo Decreto $\mathrm{n}^{\circ} 4.340$, de 22 de agosto de 2002) (MERCADANTE, 2001 apud DRUMMOND; FRANCO; OLIVEIRA, 2010) que foram sistematizados os critérios para criação e reclassificação de UCs brasileiras existentes (LEUZINGER, 2009 apud DRUMMOND; FRANCO; OLIVEIRA, 2010).

A lei do SNUC estabelece critérios e normas para a criação, implantação e gestão das UCs. De acordo com essa lei (art. $2^{\circ}$, I), a UC é o "espaço territorial e seus recursos ambientais, incluindo as águas jurisdicionais, com características naturais relevantes, legalmente instituído pelo Poder Público, com objetivos de conservação e limites definidos, sob regime especial de administração, ao qual se aplicam garantias adequadas de proteção" (BRASIL, 2000).

A lei do SNUC divide as UCs em duas categorias mais gerais: as de proteção integral e as de uso sustentável ${ }^{66}$, também denominadas como áreas de exploração indireta e direta. Essa divisão diz respeito à permissão ou não de exploração comercial extrativa ou mesmo para subsistência dos recursos naturais da UC.

As UCs de proteção integral têm como objetivo principal a preservação da natureza, sendo admitido apenas o uso indireto dos seus recursos naturais (por exemplo, recreação em contato com a natureza, turismo ecológico, pesquisa científica, educação e interpretação ambiental), com exceção dos casos previstos na lei. Já as UCs de uso sustentável visam a compatibilizar a conservação da natureza com o uso sustentável de parcela dos seus recursos naturais.

Dependendo do objetivo da UC, ela será regida por um regime jurídico próprio, o qual determinará a dominialidade do território (pública, privada ou mista) e a possibilidade de posse de população tradicional ${ }^{67}$, como ribeirinhos e caiçaras, que manejam os recursos naturais de forma sustentável e contribuem para a diversidade biológica do ambiente que ocupam (BENSUSAN, 2006 apud ARAÚJO; BARRETO, 2015).

\footnotetext{
66 “Cabe destacar que as categorias de manejo listadas acima se enquadram nos critérios definidos pela União Internacional para Conservação da Natureza (UICN). Isso permite ao sistema brasileiro uma adequação aos padrões e às normas internacionais, pois facilita a definição de estratégias para a captação de recursos, a realização de pesquisas, o intercâmbio de informações e experiências, o diálogo com agências internacionais e de outros países, a adoção de padrões diferenciados de gestão e a gestão de áreas transfronteiriças" (DRUMMOND; FRANCO; OLIVEIRA, 2010, p. 350).

${ }^{67}$ Povos e comunidades tradicionais são grupos culturalmente diferenciados e que se reconhecem como tais, que possuem formas próprias de organização social, que ocupam e usam territórios e recursos naturais como condição para sua reprodução cultural, social, religiosa, ancestral e econômica, utilizando conhecimentos, inovações e práticas gerados e transmitidos pela tradição. Definição do art. $3^{\circ}$ do Decreto no 6.040/2007, que instituiu a Política Nacional de Desenvolvimento Sustentável dos Povos e Comunidades Tradicionais (ARAÚJO; BARRETO, 2015).
} 
No processo de criação das UCs ${ }^{68}$, a eficácia da proteção a ser buscada está na escolha da categoria de proteção adotada na área, ou seja, na categoria de manejo que é escolhida no momento de sua criação com o ente responsável pela execução e gestão dessas áreas.

Analisando a Lei $n^{\circ} 9.985 / 2000$, percebe-se que um dos elementos fundamentais que define as UCs é o domínio das terras, em alguns casos, elegendo a propriedade privada (reserva particular do patrimônio natural), em outros, a posse e o domínio públicos (estação ecológica, reserva biológica, parque nacional, floresta nacional) e, em algumas hipóteses, a titularidade pública ou privada, esta desde que compatível com os objetivos da proteção (monumento natural, refúgio de vida silvestre, área de proteção ambiental, área de relevante interesse ecológico).

A titularidade das áreas não é determinada pelo grupo de que faz parte a UC ou pelo grau de ocupação humana permitido, uma vez que há unidades de uso sustentável de domínio público, como as florestas nacionais, bem como as áreas de proteção integral em que é facultada a propriedade privada, como os monumentos naturais e refúgios de vida silvestre. As características de manejo devem ser observadas para a concretização dos objetivos da UC, pois se presume que teve como fundamento a adequação aos fins almejados. Contudo a efetiva implantação de uma UC, seja de proteção integral, seja de uso sustentável, passa necessariamente pela ordenação dos direitos e deveres dos titulares de domínio ou de posse sobre as áreas respectivas. Ou a área é desapropriada e passa para o domínio público, ou são limitados e regulamentados os usos permitidos. Em outras palavras, a regularização fundiária de UCs implica não só o estudo da forma de consolidação do domínio público ou privado, mas os limites do uso do recurso natural por parte dos proprietários da área e também das populações tradicionais (ROCHA, 2002, p. 812).

O Quadro 4 traz os requisitos quanto à posse e domínio da terra para a criação de UCs para cada bioma do Brasil.

\footnotetext{
${ }^{68}$ As UCs podem ser criadas pelas três esferas de governo, União, estados e municípios, sempre por ato do poder público (lei ou decreto). Porém somente podem ser extintas ou ter a redução de seus limites (desafetada) mediante lei específica.
} 
Quadro 4 - Síntese das principais características das diferentes categorias de UCs segundo o SNUC

\begin{tabular}{|c|c|c|c|c|}
\hline $\begin{array}{l}\text { CATEGORIAS } \\
\text { DE UNIDADES }\end{array}$ & $\begin{array}{c}\text { UNIDADES DE } \\
\text { CONSERVAÇÃO }\end{array}$ & $\begin{array}{c}\text { OBJETIVOS DA } \\
\text { UNIDADE (SNUC) }\end{array}$ & $\begin{array}{l}\text { VISITAÇÃO } \\
\text { PÚBLICA }\end{array}$ & POSSE E DOMÍNIO \\
\hline \multirow{3}{*}{$\begin{array}{l}\text { UNIDADES DE } \\
\text { PROTEÇÃO } \\
\text { INTEGRAL }\end{array}$} & $\begin{array}{c}\text { Estação ecológica } \\
\text { (EE) }\end{array}$ & $\begin{array}{l}\text { A preservação da } \\
\text { natureza e a } \\
\text { realização de } \\
\text { pesquisas científicas. }\end{array}$ & $\begin{array}{l}\text { Proibido, exceto } \\
\text { com fins } \\
\text { educacionais e se } \\
\text { constar no } \\
\text { regulamento } \\
\text { específico. } \\
\end{array}$ & $\begin{array}{c}\text { Domínio e posse } \\
\text { públicos, sendo que } \\
\text { as áreas particulares } \\
\text { incluídas em seus } \\
\text { limites serão } \\
\text { desapropriadas. }\end{array}$ \\
\hline & $\begin{array}{c}\text { Reserva biológica } \\
\text { (Rebio) }\end{array}$ & $\begin{array}{c}\text { A preservação } \\
\text { integral da biota e } \\
\text { demais atributos } \\
\text { naturais, sem } \\
\text { interferência humana } \\
\text { direta ou } \\
\text { modificações } \\
\text { ambientais, } \\
\text { excetuando-se as } \\
\text { medidas de } \\
\text { recuperação de seus } \\
\text { ecossistemas } \\
\text { alterados e as ações } \\
\text { de manejo } \\
\text { necessárias para } \\
\text { recuperar e preservar } \\
\text { o equilíbrio natural, } \\
\text { a diversidade } \\
\text { biológica e os } \\
\text { processos ecológicos } \\
\text { naturais. }\end{array}$ & $\begin{array}{l}\text { Proibido, exceto } \\
\text { com fins } \\
\text { educacionais e se } \\
\text { constar no } \\
\text { regulamento } \\
\text { específico. }\end{array}$ & $\begin{array}{l}\text { Domínio e posse } \\
\text { públicos, sendo que } \\
\text { as áreas particulares } \\
\text { incluídas em seus } \\
\text { limites serão } \\
\text { desapropriadas. }\end{array}$ \\
\hline & $\begin{array}{l}\text { Parque nacional } \\
\text { (Parna) }\end{array}$ & $\begin{array}{l}\text { A preservação de } \\
\text { ecossistemas } \\
\text { naturais de grande } \\
\text { relevância ecológica } \\
\text { e beleza cênica, } \\
\text { possibilitando a } \\
\text { realização de } \\
\text { pesquisas científicas } \\
\text { e o desenvolvimento } \\
\text { de atividades de } \\
\text { educação e } \\
\text { interpretação } \\
\text { ambiental, de } \\
\text { recreação em contato } \\
\text { com a natureza e de } \\
\text { turismo ecológico. }\end{array}$ & $\begin{array}{l}\text { Sujeita a normas } \\
\text { e restrições } \\
\text { estabelecidas no } \\
\text { plano de manejo } \\
\text { e pelos órgãos } \\
\text { responsáveis por } \\
\text { sua } \\
\text { administração. }\end{array}$ & $\begin{array}{l}\text { Domínio e posse } \\
\text { públicos, sendo que } \\
\text { as áreas particulares } \\
\text { incluídas em seus } \\
\text { limites serão } \\
\text { desapropriadas. } \\
\text { Podem ser } \\
\text { criadas por estados } \\
\text { ou } \\
\text { municípios. }\end{array}$ \\
\hline
\end{tabular}




\begin{tabular}{|c|c|c|c|c|}
\hline $\begin{array}{l}\text { CATEGORIAS } \\
\text { DE UNIDADES }\end{array}$ & $\begin{array}{c}\text { UNIDADES DE } \\
\text { CONSERVAÇÃO }\end{array}$ & \begin{tabular}{|c|} 
OBJETIVOS DA \\
UNIDADE (SNUC)
\end{tabular} & $\begin{array}{l}\text { VISITAÇÃO } \\
\text { PÚBLICA }\end{array}$ & POSSE E DOMÍNIO \\
\hline \multirow{5}{*}{$\begin{array}{l}\text { UNIDADES DE } \\
\text { USO } \\
\text { SUSTENTÁVEL }\end{array}$} & $\begin{array}{l}\text { Monumento } \\
\text { natural (MN) }\end{array}$ & $\begin{array}{l}\text { Preservar sítios } \\
\text { naturais raros, } \\
\text { singulares ou de } \\
\text { grande beleza } \\
\text { cênica. }\end{array}$ & $\begin{array}{l}\text { Sujeita a normas } \\
\text { e restrições } \\
\text { estabelecidas no } \\
\text { plano de manejo } \\
\text { e pelos órgãos } \\
\text { responsáveis por } \\
\text { sua } \\
\text { administração. }\end{array}$ & $\begin{array}{l}\text { Pode ser particular } \\
\text { havendo coerência com } \\
\text { os objetivos da unidade } \\
\text { com a utilização da } \\
\text { terra e dos recursos } \\
\text { naturais pelo } \\
\text { proprietário. }\end{array}$ \\
\hline & $\begin{array}{l}\text { Refúgio da vida } \\
\text { silvestre (RVS) }\end{array}$ & \begin{tabular}{|c|} 
Proteger ambientes \\
naturais onde se \\
asseguram condições \\
para a existência ou \\
reprodução de \\
espécies ou \\
comunidades da \\
flora local e da fauna \\
residente ou \\
migratória. \\
\end{tabular} & $\begin{array}{l}\text { Sujeita a normas } \\
\text { e restrições } \\
\text { estabelecidas no } \\
\text { plano de manejo } \\
\text { e pelos órgãos } \\
\text { responsáveis por } \\
\text { sua } \\
\text { administração. }\end{array}$ & $\begin{array}{c}\text { Pode ser particular } \\
\text { havendo coerência com } \\
\text { os objetivos da unidade } \\
\text { com a utilização da } \\
\text { terra e dos recursos } \\
\text { naturais pelo } \\
\text { proprietário. }\end{array}$ \\
\hline & $\begin{array}{c}\text { Área de proteção } \\
\text { ambiental } \\
\text { (APA) }\end{array}$ & \begin{tabular}{|c|} 
Proteger a \\
diversidade \\
biológica, disciplinar \\
o processo de \\
ocupação e \\
assegurar a \\
sustentabilidade do \\
uso dos recursos \\
naturais. \\
\end{tabular} & $\begin{array}{c}\text { Normas e } \\
\text { restrições } \\
\text { serão } \\
\text { estabelecidas } \\
\text { pelo } \\
\text { órgão gestor da } \\
\text { unidade } \\
\text { ou pelo } \\
\text { proprietário. } \\
\end{array}$ & $\begin{array}{c}\text { Pública ou privada, } \\
\text { devendo respeitar as } \\
\text { exigências e restrições } \\
\text { legais. }\end{array}$ \\
\hline & $\begin{array}{l}\text { Área de relevante } \\
\text { interesse } \\
\text { ecológico (Arie) }\end{array}$ & \begin{tabular}{|c|} 
Manter os \\
ecossistemas \\
naturais de \\
importância regional \\
ou local e regular o \\
uso dessas áreas com \\
o objetivo de \\
conservação da \\
natureza. \\
\end{tabular} & $\begin{array}{c}\text { Normas e } \\
\text { restrições } \\
\text { serão } \\
\text { estabelecidas } \\
\text { pelo } \\
\text { órgão gestor da } \\
\text { unidade } \\
\text { ou pelo } \\
\text { proprietário. } \\
\end{array}$ & $\begin{array}{c}\text { Pública ou privada, } \\
\text { devendo respeitar as } \\
\text { exigências e restrições } \\
\text { legais. }\end{array}$ \\
\hline & $\begin{array}{c}\text { Floresta nacional } \\
\text { (Flona) }\end{array}$ & \begin{tabular}{|} 
O uso múltiplo \\
sustentável dos \\
recursos florestais e \\
a pesquisa científica, \\
com ênfase em \\
métodos para \\
exploração \\
sustentável de \\
florestas nativas.
\end{tabular} & $\begin{array}{l}\text { Sujeita a normas } \\
\text { e restrições } \\
\text { estabelecidas no } \\
\text { plano de manejo } \\
\text { e pelo órgão } \\
\text { responsável pela } \\
\text { sua } \\
\text { administração. }\end{array}$ & $\begin{array}{c}\text { Domínio e posse } \\
\text { públicos, sendo que as } \\
\text { áreas particulares } \\
\text { incluídas em seus } \\
\text { limites serão } \\
\text { desapropriadas. Podem } \\
\text { ser criadas pela União, } \\
\text { estados ou municípios. } \\
\text { É admitida a } \\
\text { permanência de } \\
\text { populações tradicionais } \\
\text { anteriores à criação, } \\
\text { disposto no plano de } \\
\text { manejo e regulamento } \\
\text { da unidade. }\end{array}$ \\
\hline
\end{tabular}




\begin{tabular}{|c|c|c|c|c|}
\hline $\begin{array}{l}\text { CATEGORIAS } \\
\text { DE UNIDADES }\end{array}$ & $\begin{array}{c}\text { UNIDADES DE } \\
\text { CONSERVAÇÃO }\end{array}$ & $\begin{array}{c}\text { OBJETIVOS DA } \\
\text { UNIDADE (SNUC) }\end{array}$ & $\begin{array}{l}\text { VISITAÇÃO } \\
\text { PÚBLICA }\end{array}$ & POSSE E DOMÍNIO \\
\hline & $\begin{array}{l}\text { Reserva } \\
\text { extrativista } \\
\text { (Resex) }\end{array}$ & $\begin{array}{c}\text { Proteger os meios de } \\
\text { vida e a cultura } \\
\text { dessas populações e } \\
\text { assegurar o uso } \\
\text { sustentável dos } \\
\text { recursos naturais da } \\
\text { unidade. }\end{array}$ & $\begin{array}{l}\text { É permitida, } \\
\text { desde que } \\
\text { compatível com } \\
\text { os interesses } \\
\text { locais e } \\
\text { estabelecidas no } \\
\text { plano de manejo } \\
\text { da unidade. }\end{array}$ & $\begin{array}{c}\text { Domínio público, com } \\
\text { uso concedido para } \\
\text { populações tradicionais, } \\
\text { disposto em } \\
\text { regulamentação } \\
\text { específica, sendo que as } \\
\text { áreas particulares } \\
\text { incluídas em seus } \\
\text { limites serão } \\
\text { desapropriadas. } \\
\end{array}$ \\
\hline & $\begin{array}{l}\text { Reserva de fauna } \\
\quad \text { (Refau) }\end{array}$ & \begin{tabular}{|c|} 
Proporcionar um \\
ambiente adequado \\
para estudos técnico- \\
científicos sobre o \\
manejo sustentável \\
de recursos \\
faunísticos.
\end{tabular} & $\begin{array}{c}\text { É permitida, } \\
\text { desde que } \\
\text { compatível com } \\
\text { os interesses } \\
\text { locais e } \\
\text { estabelecidas no } \\
\text { plano de manejo } \\
\text { da unidade. }\end{array}$ & $\begin{array}{l}\text { Posse e domínio } \\
\text { público, sendo que as } \\
\text { áreas particulares } \\
\text { incluídas em seus } \\
\text { limites devem ser } \\
\text { desapropriadas. }\end{array}$ \\
\hline & $\begin{array}{c}\text { Reserva de } \\
\text { desenvolvimento } \\
\text { sustentável (RDS) }\end{array}$ & \begin{tabular}{|c} 
Preservar a natureza \\
e, ao mesmo tempo, \\
assegurar as \\
condições e os meios \\
necessários para a \\
reprodução e a \\
melhoria dos modos \\
e da qualidade de \\
vida e exploração \\
dos recursos naturais \\
das populações \\
tradicionais, bem \\
como valorizar, \\
conservar e \\
aperfeiçoar o \\
conhecimento e as \\
técnicas de manejo \\
do ambiente \\
desenvolvido por \\
essas populações. \\
\end{tabular} & $\begin{array}{l}\text { Sujeita a normas } \\
\text { e restrições } \\
\text { estabelecidas no } \\
\text { plano de manejo. }\end{array}$ & $\begin{array}{l}\text { Domínio público e uso } \\
\text { concedido a populações } \\
\text { tradicionais, seguindo } \\
\text { regulamento específico. } \\
\text { As áreas particulares } \\
\text { incluídas em seus } \\
\text { limites devem ser, } \\
\text { quando necessário, } \\
\text { desapropriadas. }\end{array}$ \\
\hline & $\begin{array}{c}\text { Reserva particular } \\
\text { do patrimônio } \\
\text { natural (RPPN) }\end{array}$ & $\begin{array}{l}\text { Conservar a } \\
\text { diversidade } \\
\text { biológica e } \\
\text { promover a } \\
\text { perpetuidade. }\end{array}$ & $\begin{array}{l}\text { Apenas com fins } \\
\text { educacionais, } \\
\text { científicos, } \\
\text { turísticos ou } \\
\text { recreativos. }\end{array}$ & $\begin{array}{c}\text { Obrigatoriamente } \\
\text { privada, mas será } \\
\text { homologada apenas se } \\
\text { houver interesse } \\
\text { público. Será averbada } \\
\text { no Registro Público de } \\
\text { Imóveis. }\end{array}$ \\
\hline
\end{tabular}

Fonte: Craveiro (2009). 
A partir dos dados consolidados do $\mathrm{CNUC}^{69}$, o país possui cerca de 2.082 UCs catalogadas no $\mathrm{CNUC}^{70}$. Esse número abrange todas as esferas de governo (federal, estadual, distrital e municipal), inclusive as UCs em áreas marinhas. Se descontarmos as RPPNs, que formam um total de 844 (40,54\% do total de UCs cadastradas), esse número reduz para 1.238, porém representa apenas $0,36 \%$ do total da área do CNUC.

Chiavari et al. (2016) apresentam outros dados que têm como fonte o MMA/CNUC. Os dados das UCs foram consultados no ano de 2016, são eles: 2.029 UCs no Brasil, ocupando uma área de 154.415.900 ha (18,1\% do território brasileiro), das quais, 786 UCs são de domínio público e necessitam de regularização fundiária, ocupando uma área de 110.690.300 ha.

A Tabela 6 apresenta as UCs cadastradas no CNUC por bioma.

${ }^{69}$ Os dados consolidados do CNUC estão disponíveis em: <http://www.mma.gov.br/areas-protegidas/cadastronacional-de-ucs/dados-consolidados>; acesso em: 25 set. 2018.

${ }^{70}$ Descontamos aqui as UCs marinhas. 
Tabela 6 - UCs cadastradas no CNUC por bioma, em julho de 2017

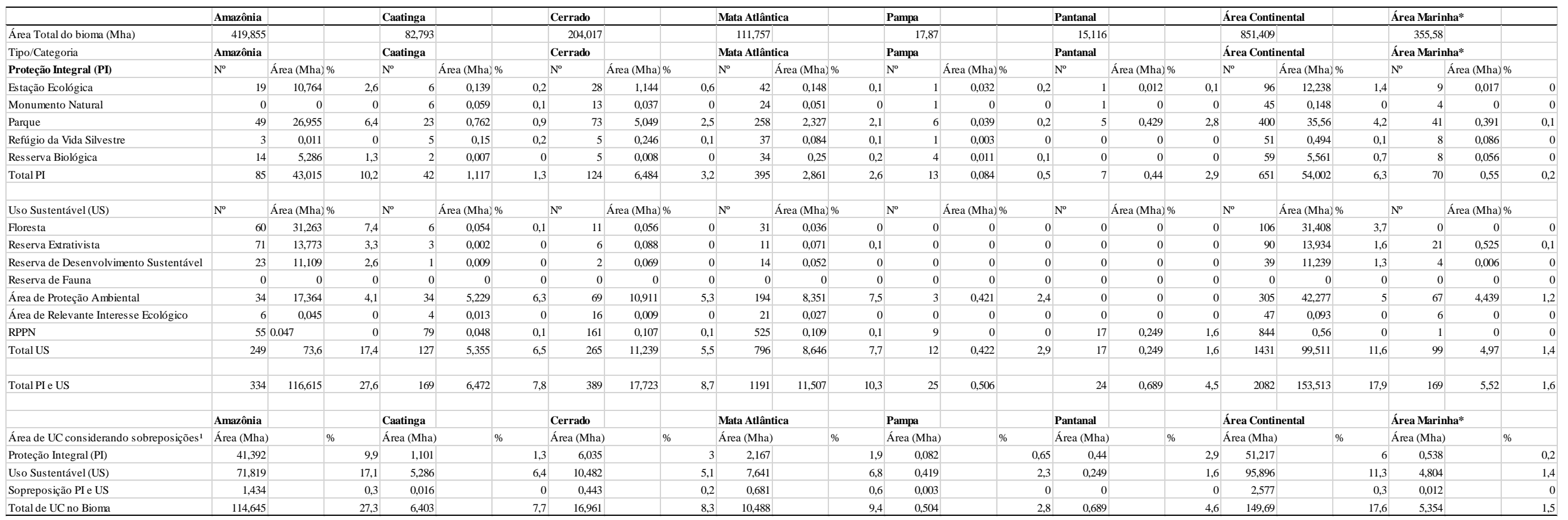

Fonte: CNUC/MMA (10 jul. 2017).

Notas: ${ }^{1}$ As áreas de sobreposição consideradas foram obtidas a partir dos arquivos com dados espaciais cadastrados e validados no CNUC.

* Área marinha corresponde ao Mar Territorial mais a Zona Econômica Exclusiva (ZEE).

Obs. 1: A UC que não tem informação georreferenciada disponível é utilizada a área do ato legal para o cálculo de área.

Obs. 2: Os dados do CNUC estão em constante atualização. Ao utilizá-los, sempre citar a data.

Obs. 3: Não somar o número de UCs de biomas diferentes, pois há casos em que uma UC abrange mais de um bioma.

Notas de versão: 32 novas UCs, 11 alterações maiores que 10 ha, 4 desativações, incremento de $4.549 \mathrm{~km}^{2}$ descontadas sobreposições. 
O bioma da Amazônia possui 10,2\% de sua área com UCs de proteção integral, sendo 17,4\% de UCs de uso sustentável, totalizando uma porcentagem de 27,6\% de área sob proteção ambiental em UCs. A Mata Atlântica é o segundo bioma em área protegida pela instituição de UCs, respectivamente, $2,6 \%$ de sua área sob proteção integral e 7,7\% sob uso sustentável. O Cerrado é o terceiro bioma em \% de área ocupada por UCs, sendo, respectivamente, $3,2 \%$ de proteção integral e 5,5\% de uso sustentável ${ }^{71}$.

O objeto de pesquisa deste trabalho refere-se somente às UCs de domínio público, como será tratado no capítulo 6, que aborda a metodologia deste trabalho. Nessas UCs, o ato da criação das UCs já pressupõe a necessidade da regularização fundiária, processo necessário para fazer com que a área que integra a UC esteja na posse e domínio federal, estadual ou municipal, para que esse ente responsável execute sua gestão.

Nas UCs de posse e domínio público, as áreas privadas precisam ser desapropriadas ou indenizadas, sendo primordial que, além do mapeamento fundiário, seja realizada previsão orçamentária para as desapropriações e indenizações, em etapa anterior à criação da UC.

Tanto na criação das UCs quanto para a sua desapropriação, as instituições que eram responsáveis pela sua gestão, antes do ano de 2002 (com o decreto que regulamentou o SNUC), careciam de normas e procedimentos de regularização fundiária, nem mesmo exigiam estudos fundiários $^{72}$ - necessários para a criação e futura desapropriação das propriedades inseridas nas áreas das UCs de domínio público, como também para a transferência de terras sob competência de outros órgãos públicos federais, estaduais e municipais ${ }^{73}$.

Durante anos, o procedimento de desapropriação de propriedades privadas no interior de UCs de domínio público seguiu as regras previstas no Decreto-Lei nº 3.365/1941, que dispõe sobre desapropriações por utilidade pública. O procedimento desse decreto-lei é extremamente burocrático, longo e oneroso. Muitas outras regras foram sendo criadas, porém eram

\footnotetext{
${ }^{71}$ A análise detalhada das UCs de domínio público do Cerrado está presente no capítulo 6 deste documento.

${ }^{72}$ Anteriormente à Lei $n^{\circ} 9.985 / 2000$, as categorias de espaços especialmente protegidos não estavam organizadas de forma sistêmica e existiam várias lacunas em seu regime jurídico, até mesmo quanto ao domínio das áreas. Com a lei do SNUC, as unidades preexistentes passaram a ser regidas por suas normas, e aquelas desconformes às categorias previstas deveriam ser "reavaliadas, no todo ou em parte, no prazo de até 2 (dois) anos, com o objetivo de definir sua destinação com base na categoria e função para as quais foram criadas" (BRASIL, 2000). "Assim, com a definição normativa acerca da dominialidade nas diferentes categorias, evidenciou-se a necessidade de regularização das UCs anteriormente criadas. Também para a consolidação dominial das unidades preexistentes é essencial a realização do diagnóstico da situação fundiária, incluindo tanto levantamento da ocupação quanto cartorário, para a elaboração de planejamento viável da regularização fundiária" (OLIVEIRA, 2010, p. 163-164, grifos da autora).

${ }^{73}$ Chiavari et al. (2016) mencionam todas as portarias e normas para a transferência de domínio de terras públicas para o órgão gestor da UC.
} 
desarticuladas e incompletas e, por isso, as ações de desapropriação propostas não foram suficientes para a regularização fundiária das UCs (KURY, 2009).

Dessa forma, as normas e as diretrizes para se criar as UCs, assim como para regularizálas, não estavam previstas de forma completa em apenas uma legislação que versasse sobre esses temas, nem mesmo nas diversas leis que tratavam sobre o tema, sendo quase impossível obter uma visão clara das etapas e regras para a regularização das terras nas UCs. As regras para se regularizar as UCs estavam esparsas, e a principal dificuldade deste processo de regularização era a exigência da comprovação da cadeia dominial da propriedade desde a sua origem $^{74}$ (KURY, 2009).

A lacuna deixada pela inexistência de uma norma que orientasse o ato de criação das UCs não foi preenchida com a criação do SNUC, pois ele não explicita o procedimento a ser adotado na criação de novas $\mathrm{UCs}^{75}$, apesar de indicar alguns atos que, necessariamente, deverão ser executados. Nesse sentido, seu artigo 22 (apud OLIVEIRA, 2010, p. 158) prevê que a instituição será feita por ato do poder público, "precedida de estudos técnicos e de consulta pública que permitam identificar a localização, a dimensão e os limites mais adequados para a unidade, conforme se dispuser em regulamento".

Somente com a IN $\mathrm{n}^{\circ} 5$, de 15 de maio de $2008^{76}$, editada pelo ICMBio, foi regulamentada a realização de consulta pública para a criação das UCs e a realização de estudos técnicos ${ }^{77}$, entres estes, estudos fundiários, que seriam objetos para as regularizações fundiárias posteriores, para subsidiar efetivamente tanto o poder público quanto a sociedade na tomada de decisões (OLIVEIRA, 2010; CHIAVARI et al., 2016). Isto é, antes da criação de uma UC, é fundamental que se faça um levantamento socioeconômico, identificando se existem comunidades tradicionais ou indígenas, um diagnóstico fundiário, determinando se a área é pública ou particular, e que seja realizada uma previsão orçamentária para as desapropriações

\footnotetext{
74 Atualmente é preciso comprovar a cadeia dominial dos últimos 30 anos, o que ainda é bem complexo, dada a fragilidade dos sistemas de administração fundiária brasileira.

${ }^{75}$ Contudo, a correspondente regulamentação, feita pelo Decreto ${ }^{\circ} 4.340 / 2002$, não traz qualquer outra norma sobre o procedimento de criação de UCs, prevendo que "cada categoria de unidade de conservação integrante do SNUC será objeto de regulamento específico" (art. 46), que ainda não exsurgiu (OLIVEIRA, 2010, p. 158; KURY, 2009).

${ }^{76}$ A IN no 5 (15 de maio de 2008) "dispõe sobre o procedimento administrativo para a realização de estudos técnicos e consulta pública para a criação de unidade de conservação federal”, prevendo, entre outros levantamentos, a "caracterização da população residente, contendo o número e tamanho médio das propriedades e o padrão de ocupação da área” (art. 4) (apud OLIVEIRA, 2010, p. 159).

77 De acordo com essa instrução normativa, os estudos técnicos devem apresentar: caracterização das diferentes formações vegetais e sua fauna associada; caracterização do uso do solo dentro dos limites propostos; caracterização da população residente, contendo o número e tamanho médio das propriedades; o padrão de ocupação da área, dentre outros (CHIAVARI et al., 2016).
} 
e indenizações, em etapa anterior à criação da UC. Da mesma forma, é preciso ter programas e orçamento para o reassentamento de populações tradicionais em UCs de proteção integral. Por anos, esses requisitos não foram considerados na criação das UCs, resultando num passivo fundiário que escapa ao controle do Estado devido à fragilidade de sua governança de terras.

O procedimento para avaliação e indenização dos imóveis e benfeitorias somente foi regulamentado na IN do ICMBio $\mathrm{n}^{\mathrm{o}} 2$, de 3 de setembro de $2009^{78}$, tanto para as UCs preexistentes como para as UCs criadas na vigência do SNUC, no ano de 2002 (OLIVEIRA, 2010, p. 166). Apesar de a IN no 2 (3 de setembro de 2009) regulamentar os procedimentos para avaliação e indenização dos imóveis e benfeitorias, não há regulamento explicitando quando e como as desapropriações devem ocorrer. A Lei $\mathrm{n}^{\circ}$ 9.985, de 18 de julho de 2000, - que instituiu o SNUC - estabelece os critérios e normas para a criação, implantação e gestão das UCs, todavia não prevê nenhuma obrigatoriedade na disposição de recursos para a criação de uma UC, por exemplo, na indenização de proprietários que se encontravam na área antes de sua criação $^{79}$.

No Brasil, o ato de criação formal de uma UC, a despeito de ausência de norma expressa em nosso ordenamento jurídico, dá-se em geral por meio de decreto do poder executivo de algum dos entes federativos, sendo apenas um primeiro passo no caminho a ser percorrido para que os objetivos para os quais ela foi concebida sejam, de fato, implementados. O fato é que o ato de criação da UC não ultrapassa a promulgação do decreto que institui sua criação (BRASIL, 2014, p. 7).

Desse cenário, decorre que muitas UCs são criadas sem previsão orçamentária para executar as desapropriações necessárias e sem que haja um processo de implantação efetiva desses espaços, o que envolveria responsabilidades política, legal e financeira na sua conservação e no seu manejo. Em razão desse contexto, muitas UCs - que ainda não realizaram suas indenizações - receberam o apelido de "parques de papel” (BRITO, 2000 apud SARETTA,

\footnotetext{
${ }^{78}$ De acordo com o manual de regularização fundiária (BRASIL, 2014, p. 40), não existe organizado em um só documento a descrição do procedimento administrativo para a regularização fundiária das UCs, o que termina por conferir ao poder público uma dose de liberdade de conformação a esse respeito. Porém, o ICMBiolMMA ([2011]) publicaram uma cartilha com o objetivo de demonstrar, na prática, todos os passos da aplicação da instrução normativa que trata da indenização de benfeitorias e desapropriação de imóveis em UCs federais (IN/ICMBio $\mathrm{n}^{\circ}$ 2/2009) desde a abertura do processo de indenização até a transferência das áreas pelo ICMBio. São elas: 1) realização de um levantamento ocupacional das pessoas que se encontram no interior da UC; 2) levantamento cartorial que apontasse as propriedades registradas no interior da área; 3) elaboração de um diagnóstico acerca da situação fundiária global da UC; 4) elaboração do plano de regularização fundiária da unidade; 5) efetivo implemento do plano de regularização fundiária (ICMBIO/MMA, [2011]).

${ }^{79}$ Segundo Oliveira (2010, p. 162, grifos da autora), "diante da inexistência de previsão normativa específica, deve ser adotado como prazo máximo para a consolidação dominial o previsto no Decreto-lei n. 3.365/1941 para ajuizamento da ação desapropriatória, qual seja, cinco anos a partir da criação da unidade de conservação [...]”.
} 
2017; DOUROJEANNI, 2002 apud SARETTA, 2017; TERBORGHE VAN SCHAIK, 2002 apud SARETTA, 2017).

Segundo Maciel (MMA, 2011), a criação da UC não caracteriza a transferência de domínio. Esta exige a identificação e transferência de domínio ou posse dos imóveis contidos no interior do perímetro decretado de cada UC para o seu órgão gestor de acordo com a norma regulamentada pela IN n ${ }^{\circ}$ 2/2009 do ICMBio.

Nesse sentido, a transferência de domínio ocorre com a regularização fundiária, que é uma das atividades necessárias para a consolidação territorial das UCs. Esta consolidação territorial consiste em um conjunto de ações voltadas para a efetivação das condições necessárias para o cumprimento dos objetivos básicos e específicos de cada UC. Duas ações são fundamentais para que ocorra a consolidação territorial das UCs de domínio público: regularização da situação fundiária e consolidação de limites (diagnóstico preliminar do perímetro, identificação de sobreposições, readequação dos memoriais descritivos, demarcação topográfica e sinalização de perímetro) (MMA, 2011; OLIVEIRA, 2010).

A consolidação territorial das UCs compreende a demarcação topográfica, a sinalização do perímetro das UCs, ou seja, de consolidação dos limites, que consiste na verificação de eventuais sobreposições com outros espaços protegidos, demarcações topográficas e sinalização gráfica dos limites da unidade. Essas são informações fundamentais para que ocorra a transferência de domínio que é a regularização da situação fundiária das UCs.

A regularização fundiária não é, assim, um instituto jurídico único, pois pode
englobar vários instrumentos, como as discriminatórias administrativas e
judiciais de terras devolutas (Lei $\mathrm{n}^{\circ} 6.368 / 1976$ ); a retificação de registros
imobiliários que, com base na Lei $\mathrm{n}^{\circ} 10.267$, de 28 de novembro de 2001,
passou a exigir a apresentação de memoriais descritivos com indicação das
coordenadas georreferenciadas ao Sistema Geodésico Brasileiro; a
desapropriação, consensual ou judicial etc. (OLIVEIRA, 2010, p. 154). As ações de regularização fundiária, somadas com as de consolidação dos limites, acarretam a consolidação territorial das Unidades de Conservação, o que, por sua vez, representa um importante passo a ser dado para a efetiva implementação, de modo que possam exercer a finalidade ambiental para a qual foi criada (BRASIL, 2014, p. 8).

Segundo Andrade (2011), a expressão “consolidação territorial” é mais precisa e abrangente do que a comumente utilizada "regularização fundiária", pois, enquanto a regularização fundiária corresponde ao processo pelo qual o ocupante de terras públicas sem justo título recebe do poder público um título legítimo, conduzindo-o a uma situação de legalidade, a consolidação territorial abrange diversas ações, como: a consolidação de limites, a regularização de terras públicas, a gestão e manejo de conflitos socioambientais, o 
reassentamento de populações residentes, a pactuação de termos de compromissos e, principalmente, a aquisição de terras e benfeitorias.

De acordo com o ICMBio (2012), a efetiva implantação de uma UC exige a prática de uma série de outros atos além da sua mera criação. Grosso modo, pode-se identificar as seguintes providências para a efetiva implementação de uma UC já criada: a) consolidação territorial, que, por sua vez, divide-se em: a.1) regularização fundiária e a.2) consolidação dos limites; b) implementação do Conselho Gestor (que pode ser deliberativo ou consultivo); c) elaboração do plano de manejo ${ }^{80}$.

Sem a observância das características previstas em lei para a modalidade de UC eleita e sem um plano de manejo em constante revisão, cai-se no vazio da proteção meramente formal. Em outras palavras, “[...] a criação de espaços protegidos sem a consequente aplicação das restrições e normas de manejo adequadas à consecução dos fins pretendidos transforma em mera ilusão a proteção almejada" (OLIVEIRA, 2010, p. 151).

A complexidade do processo de demarcação e arrecadação de terras devolutas, as inconsistências na cadeia dominial constantes dos Cartórios de Registros de Imóveis, a existência de títulos de propriedade falsos, a escassez de recursos financeiros para custear as indenizações e os obstáculos ao processo de reassentamento das famílias são os principais empecilhos encontrados no processo de regularização fundiária das UCs do bioma Amazônia (TCU, 2013, p. 60), sendo que esses empecilhos se estendem para todas as UCs brasileiras ${ }^{81}$.

De acordo com diagnóstico do ICMBio (2012) sobre as dificuldades na aquisição de terras em UCs e na regularização fundiária dessas áreas, o instituto aponta a existência de problemas históricos, como: a complexa legislação, a falta de padronização dos procedimentos

\footnotetext{
${ }^{80}$ A escolha da modalidade de UC que pressupõe uma dominialidade não é suficiente para garantir a proteção necessária aos espaços territorialmente protegidos, que é feita também por meio do plano de manejo, que é um "documento técnico mediante o qual, com fundamento nos objetivos gerais de uma unidade de conservação, se estabelece o seu zoneamento e as normas que devem presidir o uso da área e o manejo dos recursos naturais, inclusive a implantação das estruturas físicas necessárias à gestão da unidade (Lei n 9.985/2000, art. $2^{\circ}$, XVII). Cabe lembrar que esse regime especial de administração, traduzido pelo Plano de Manejo (PM), integra a própria definição de unidade de conservação (Lei no 9.985/2000, art. 2º I) [...]" (OLIVEIRA, 2010, p. 152). Trata-se de documento no qual devem constar os objetivos e as estratégias para atingi-los. Segundo Cases (2012, p. 82): “[...] um instrumento para a gestão da unidade de conservação, produto de um processo de planejamento, que prescreve a situação final que se quer atingir (os objetivos que se desejam alcançar e o zoneamento) e as estratégias para tal". Considerando o destaque dado pela literatura aos planos de manejos, pode-se afirmar que atualmente a situação brasileira ainda é bastante insatisfatória, com os últimos dados do ICMBio de agosto 2017 apontando que aproximadamente 54,94\% das UCs sob sua gestão contam com PMs vigentes, ou seja, 171. Das 326 UCs sob controle do ICMBio, 99 delas estavam com seu plano de manejo em elaboração. Para consultar as unidades de conservação que possuem os planos de manejo vigentes, acesse: <http://www.icmbio.gov.br/portal/planosmanejo>.

${ }^{81}$ Kury (2009), Iwama, Lima e Pellin (2014), Chaves (2014), Oliveira (2009) e Costa Neto (2018) analisaram a situação fundiária para a regularização das UCs em diversas UCs do país e encontraram todos esses conflitos para se regularizar as áreas.
} 
de regularização fundiária, a inexistência ou fragilidade das normas, a carência de pessoal especializado, os limitados recursos financeiros, conflitos socioambientais e/ou resistências contra as UCs, entre outros fatores.

Nessa mesma linha, o ICMBio (2012) já apontou que os dados disponíveis não permitem definir categoricamente qual a situação fundiária das UCs federais, uma vez que ainda não foi possível reunir todo o acervo de informações dos órgãos que antecederam o ICMBio. Ademais, esse órgão destaca que não é possível informar detalhadamente os dados dos proprietários e imóveis já desapropriados, nem daqueles que ainda estão no processo.

Vale mencionar o que foi discutido no capítulo 4 deste trabalho, sobre a fragilidade da administração de terras do Brasil. No caso das UCs, os dados do CNUC são imprecisos e desatualizados e não existe integração com o cadastro fundiário e com o sistema de registro de imóveis, dificultando a identificação e legalidade das posses da cadeia dominial das propriedades no interior das UCs. São esses fatores que geram conflitos de sobreposição de áreas que viabilizam o estudo fundiário da UCs.

Diante da realidade da situação fundiária das UCs, os governos não têm a estrutura necessária para realizar o diagnóstico e oferecer uma solução para suas ocupações.

As políticas institucionais e financeiras do poder público que procuram implementar efetivamente as UCs criadas têm sido marcadas por ações insuficientes, pontuais e desarticuladas. Tais políticas confrontam-se com vários problemas, como falta de planos de manejo (ou planos desatualizados), necessidade de demarcação das áreas em campo e baixa regularização fundiária das UCs. De acordo o Tribunal de Contas da União (TCU, 2013), apenas 4\% das UCs no bioma Amazônia apresentam alto grau de implementação.

Além das deficiências apontadas pelo TCU, o ICMBio, que é referência para os órgãos ambientais estaduais, trabalha com um processo administrativo para desapropriação de imóveis e indenização de benfeitorias complexo, custoso e moroso. De acordo com o ICMBio, a demora é resultado de: i) corpo técnico extremamente reduzido e sem formação para ações indenizatórias; ii) poucas informações gerenciais e baixo controle do patrimônio fundiário; iii) insuficiência de recursos orçamentários e financeiros; iv) centralização do término dos processos em Brasília (MACIEL, 2012 apud ARAÚJO; BARRETO, 2015).

Em suma, a situação fundiária das UCs é bastante complexa e envolve uma série de situações, como terrenos de marinha e/ou acrescidos, ilhas, terrenos marginais, várzeas, mar territorial, entre outros, assim como áreas geridas por diversos órgãos federativos, tais como SPU, Incra, Ibama e ICMBio, e até mesmo estaduais ou terras de domínio privado. 
Rocha, Drummond e Ganem (2010, p. 214-215), referindo-se aos parques nacionais (Parnas) brasileiros, afirmam que estes

[...] constituem no seu conjunto, mosaicos patrimoniais caracterizados por inúmeras situações: terras de domínio do Estado ocupadas ou não por posseiros ou intrusos; terras de particulares, muitas vezes de domínio indefinido ou contestável, exploradas ou não; terras de particulares ocupadas pelos PNs [parques nacionais] ou por posseiros; terras devolutas ou "terras de ninguém" ocupadas pelos PNs ou por posseiros (GUATURA, CORREA \& COSTA, 1997).

Nas situações em que há propriedades privadas não indenizadas no interior de UCs, ocorre um conflito de interesses, em que, de um lado, o poder público fica limitado para impor as regras que garantem a plena conservação daquele espaço ocupado e, de outro, o proprietário fica com o direito de propriedade limitado, não podendo utilizar a área como desejar.

Saretta (2017), a partir de entrevistas com os principais stakeholders relacionados com a temática das UCs, elencou os potenciais impactos socioambientais decorrentes da permanência de propriedades privadas no interior de UCs. Segundo a autora:

O poder público responsável pela UC não consegue realizar a gestão efetiva da área com a permanência de privados em seu interior.

Propriedades privadas no interior de UCs de domínio público enquanto não desapropriadas não se submetem às vedações típicas de uma UC.

A manutenção de atividade/exploração no interior de UCs impede a regeneração e/ou a recomposição da vegetação.

Fauna e flora podem ser impactadas por práticas de manejo de solo incompatíveis com a conservação ambiental, por uso de agrotóxicos, assoreamento, fogo, desmatamento, etc.

Construção de vias de acesso no interior das UCs e trânsito desnecessário.

Conflitos socioambientais entre os proprietários não indenizados e o poder público. Em Resex os conflitos socioambientais envolvem também as comunidades tradicionais.

Degradação proposital de áreas no interior de UCs pelos proprietários privados (ex.: incêndios intencionais).

Permanência de proprietários privados no interior das UCs desprovidos da possibilidade de explorar a área, sem renda e à espera de indenização danifica a imagem da UC ante a comunidade local.

UCs não consolidadas do ponto de vista fundiário estão mais sujeitas à desafetação da área, à alteração de seus limites e/ou à mudança de categoria (SARETTA, 2017, p. 66).

Conforme informações contidas na ata da reunião do Plano de Regularização Fundiária datada em $2012^{82}$, existem, atualmente, cerca de 64,6 milhões ha, distribuídos em 251 UCs, cujos usos e domínios das terras devem ser obrigatoriamente públicos (ICMBIO, 2012).

\footnotetext{
${ }^{82}$ Por meio da Portaria Interministerial $n^{\circ} 391$, de 4 de outubro de 2011, foi instituído um Grupo de Trabalho Interministerial (GTI) composto por representantes do MMA, MDA, Incra, SPU e ICMBio para, sob a coordenação deste último, propor o Plano de Regularização Fundiária de Unidades de Conservação Federais, estabelecer um cronograma para regularizar a situação fundiária das UCs, bem como prever os mecanismos financeiros para a sua execução (ICMBIO, 2012). O objetivo do plano era definir diretrizes e estratégias para
} 
Já os dados do ICMBio (apud TCU, 2013, p. 58) estimam que dos 75 milhões ha de UCs federais, aproximadamente, 5,4 milhões ha de UCs estão pendentes de regularização fundiária, seja por falta de desapropriação ou indenização de benfeitorias.

A auditoria do TCU (2013, p. 59) estima que existam 18 milhões ha de terras devolutas no interior de UCs federais que ainda não passaram pelo processo de discriminação. Além disso, o ICMBio espera que sejam transferidas em torno de 10 milhões ha de terras públicas estaduais para o domínio da União (ICMBIO, 2012).

A política de regularização fundiária não tem alcançado o seu objetivo maior, qual seja, o de fazer com que as suas terras sejam, em sua totalidade, de posse e domínio públicos. Rocha, Drummond e Ganem (2010) evidenciaram que a questão nunca recebeu a devida prioridade dos órgãos competentes. Esses autores analisaram a situação fundiária dos Parnas, mostrando a inconsistência dos dados de sua regularização fundiária.

De acordo com esses autores, a Tabela 7 apresenta a situação dos Parnas criados até 2000, para os quais se obteve os dados mais completos e organizados do Ibama. Os dados mostram as áreas "regularizada" e "a regularizar" e o percentual regularizado de cada unidade. Embora cerca de $86 \%$ da área total dos Parnas criados até aquele ano constassem como regularizados, 28 (66\%) desses 44 Parnas tinham problemas fundiários registrados. Ou seja, bem mais da metade ainda tinha terras em mãos de particulares e/ou fora do domínio público efetivo (ROCHA; DRUMMOND; GANEM, 2010).

Há o agravante de que 15 unidades (34\% desses mesmos 44 parques) tinham menos de 50\% de sua superfície sob domínio público (ROCHA; DRUMMOND; GANEM, 2010, p. 210).

promover a consolidação territorial das UCs federais, com foco na regularização da situação fundiária e demarcação e sinalização física de seus limites. O plano, além de contemplar as ações específicas de regularização fundiária, sob a responsabilidade da Coordenação Geral de Consolidação Territorial (CGTER/ICMBio), também possuía ações de competência de outros órgãos, que foram consideradas essenciais para viabilizar a sua execução, dessa forma, este apresentava um caráter intra e interinstitucional. Segundo o ICMBio (2012), os resultados esperados, ao longo do período total de execução do plano (2012 a 2021), são os seguintes: (a) incorporação de 6,5 milhões hectares de áreas de domínio privado ao patrimônio do ICMBio, por desapropriação ou doação; (b) incorporação de 5 milhões de hectares de terras devolutas ao patrimônio da União; (c) transferência de 10 milhões de hectares de terras estaduais, inseridas em UCs, para o domínio da União; (d) obtenção de termo de entrega e a Concessão de Direito Real de Uso (CDRU) para 60 UCs; (e) emissão de CDRU para 28 mil famílias de populações tradicionais; (f) demarcação e sinalização do perímetro de 120 UCs; (g) cadastramento de famílias em 80 UCs; (h) reassentamento de 10 mil famílias residentes em UCs. Porém, este plano nunca foi executado em sua integralidade. 
Tabela 7 - Situação fundiária dos parques nacionais do Brasil existentes em 2000

\begin{tabular}{|c|c|c|c|c|c|c|c|}
\hline NOME / LOCALIZAÇÃO & $\begin{array}{c}\text { ANO DE } \\
\text { CRIAÇÃO }\end{array}$ & $\underset{\text { (ha) }}{\text { ÁREA TOTAL }}$ & $\begin{array}{c}\text { ÁREA } \\
\text { REGULARIZADA } \\
\text { (ha) }\end{array}$ & $\begin{array}{c}\text { ÁREA A } \\
\text { REGULARIZAR } \\
\text { (ha) }\end{array}$ & DEMARCAÇÃO & $\begin{array}{l}\text { LEVANTAMENTO } \\
\text { FUNDIÁRIO }\end{array}$ & $\begin{array}{c}\text { ÁREA } \\
\text { REGULARIZA } \\
\text { DA }(\%)\end{array}$ \\
\hline 1.Itatiaia (RJ e MG) & 1937 & 30000 & 10000 & 20000 & SIM & SIM & 33 \\
\hline 2.Iguaçu (PR) & 1939 & 185262 & 185262 & 0 & SIM & SIM & 100 \\
\hline 3.Serra dos Órgãos (RJ) & 1939 & 11113 & 3298 & 7815 & $\mathrm{NÃO}$ & $\mathrm{NÃO}$ & 30 \\
\hline 4.Ubajara $(\mathrm{CE})$ & 1959 & 6299 & 6299 & 0 & SIM & SIM & 100 \\
\hline 5.Aparados da Serra (RS) & 1959 & 10250 & 5950 & 4300 & SIM & PARCIAL & 58 \\
\hline 6.Araguaia (TO) & 1959 & 562312 & 450312 & 112000 & SIM & PARCIAL & 80 \\
\hline 7.Emas (GO) & 1961 & 131868 & 120868 & 11000 & SIM & SIM & 92 \\
\hline 8.Chapada dos Veadeiros (GO) & 1961 & 65038 & 11000 & 54038 & SIM & SIM & 18 \\
\hline 9.Caparaó (MG e ES) & 1961 & 26000 & 6000 & 20000 & SIM & PARCIAL & 23 \\
\hline 10.Sete Cidades (PI) & 1961 & 7700 & 7700 & 0 & SIM & SIM & 100 \\
\hline 11. São Joaquim (SC) & 1961 & 49300 & 4930 & 44370 & $\mathrm{NÃO}$ & NÃO & 10 \\
\hline 12. Tijuca (RJ) & 1961 & 3200 & 2499 & 701 & NÃO & NÃO & 78 \\
\hline 13. Brasília (DF) & 1961 & 30000 & 26500 & 3500 & SIM & SIM & 88 \\
\hline 14. Monte Paschoal (BA) & 1961 & 22383 & 22383 & 0 & SIM & SIM & 100 \\
\hline 15. Serra da Bocaina (RJ e SP) & 1971 & 100000 & 8000 & 92000 & $\mathrm{NÃO}$ & $\mathrm{NÃO}$ & 8 \\
\hline 16. Serra da Canastra (MG) & 1972 & 71525 & 71525 & 0 & SIM & SIM & 100 \\
\hline 17. Amazônia (AM e PA) & 1974 & 994000 & 744100 & 249900 & NÃO & NÃO & 75 \\
\hline 18. Serra da Capivara (PI) & 1979 & 100000 & 100000 & 0 & SIM & SIM & 100 \\
\hline 19. Pico da Neblina (AM) & 1979 & 2200000 & 2090000 & 110000 & NÃO & NÃO & 95 \\
\hline 20. Pacaás Novos (RO) & 1979 & 764801 & 764801 & 0 & NÃO & NÃO & 100 \\
\hline 21. Cabo Orange (AP) & 1980 & 619000 & 568000 & 51000 & $\mathrm{NÃO}$ & NÃO & 92 \\
\hline 22. Jaú (AM) & 1980 & 2272000 & 2233307 & 38693 & $\mathrm{NÃO}$ & NÃO & 98 \\
\hline 23. Lençóis Maranhenses (MA) & 1981 & 155000 & 155000 & 0 & $\mathrm{NÃO}$ & NÃO & 100 \\
\hline $\begin{array}{l}\text { 24. Pantanal Mato-Grossense } \\
\text { (MT) }\end{array}$ & 1981 & 135000 & 135000 & 0 & SIM & SIM & 100 \\
\hline 25. Abrolhos (BA) & 1983 & 91235 & 91235 & 0 & $\mathrm{NÃO}$ & NÃO & 100 \\
\hline 26. Serra do Cipó (MG) & 1984 & 33800 & 15545 & 18255 & SIM & SIM & 46 \\
\hline 27. Chapada Diamantina (BA) & 1985 & 152000 & 0 & 152000 & SIM & PARCIAL & 0 \\
\hline
\end{tabular}


Tabela 7 - Situação fundiária dos parques nacionais do Brasil existentes em 2000 (continuação)

\begin{tabular}{|c|c|c|c|c|c|c|c|}
\hline NOME / LOCALIZAÇÃO & $\begin{array}{r}\text { ANO DE } \\
\text { CRIAÇÃO }\end{array}$ & $\begin{array}{c}\text { ÁREA } \\
\text { TOTAL } \\
\text { (ha) }\end{array}$ & $\begin{array}{c}\text { ÁREA } \\
\text { REGULARIZ } \\
\text { ADA } \\
\text { (ha) } \\
\end{array}$ & $\begin{array}{c}\text { ÁREA A } \\
\text { REGULARIZAR } \\
\text { (ha) }\end{array}$ & $\begin{array}{l}\text { DEMAR } \\
\text { CAÇÃOO }\end{array}$ & $\begin{array}{c}\text { LEVANTAMENTO } \\
\text { FUNDIÁRIO }\end{array}$ & $\begin{array}{c}\text { ÁREA } \\
\text { REGULARI } \\
\text { ZADA }(\%)\end{array}$ \\
\hline 28. Lagoa do Peixe (RS) & 1986 & 34400 & 4000 & 30400 & SIM & SIM & 12 \\
\hline 29. Fernando de Noronha (PE) & 1988 & 11270 & 11270 & 0 & SIM & SIM & 100 \\
\hline 30. Chapada dos Guimarães (MT) & 1989 & 33000 & 4889 & 28111 & SIM & SIM & 15 \\
\hline 31. Grande Sertão, Veredas (MG e BA) & 1989 & 231668 & 16800 & 214868 & SIM & SIM & 7 \\
\hline 32. Superagui (PR) & 1989 & 21000 & 0 & 21000 & SIM & PARCIAL & 0 \\
\hline 33. Serra do Divisor (AC) & 1989 & 605000 & 378900 & 226100 & NÃO & NÃO & 63 \\
\hline 34. Monte Roraima (RR) & 1989 & 116000 & 116000 & 0 & SIM & SIM & 100 \\
\hline 35. Serra Geral (RS) & 1992 & 18000 & 0 & 18000 & $\mathrm{NÃO}$ & $\mathrm{NÃO}$ & 0 \\
\hline 36. Ilha Grande (PR e MS) & 1997 & 78875 & 47325 & 31550 & NÃO & $\mathrm{NÃO}$ & 60 \\
\hline 37. Restinga de Jurubatiba (RJ) & 1998 & 14800 & 0 & 14800 & NÃO & NÃO & 0 \\
\hline 38. Serra da Mocidade (RR) & 1998 & 350950 & 350950 & 0 & $\mathrm{NÃO}$ & $\mathrm{NÃO}$ & 100 \\
\hline 39. Viruá (RR) & 1998 & 227011 & 227011 & 0 & NÃO & NÃO & 100 \\
\hline 41. Pau Brasil (BA) & 1999 & 11538 & 0 & 11538 & $\mathrm{NÃO}$ & $\mathrm{NÃO}$ & 0 \\
\hline 42. Descobrimento (BA) & 1999 & 21129 & 0 & 21129 & NÃO & $\mathrm{NÃO}$ & 0 \\
\hline 43. Cavernas do Peruaçu (MG) & 1999 & 58800 & 58800 & 0 & NÃO & NÃO & 100 \\
\hline 44. Serra da Bodoquena (MS) & 2000 & 77232 & 0 & 77232 & NÃO & NÃO & 0 \\
\hline
\end{tabular}

Fonte: Rocha (2002 apud ROCHA; DRUMMOND; GANEM, 2010). 
Segundo Rocha, Drummond e Ganem (2010), a Tabela 7 evidencia que não existe uma relação positiva entre as datas de criação dos Parnas e as suas respectivas situações de regularização fundiária. Ou seja, as unidades mais antigas não estavam em situação melhor que as de idade intermediária ou as mais recentes. Essa observação reforça o argumento de que as pendências fundiárias são crônicas na política brasileira de Parnas.

Rocha, Drummond e Ganem (2010) realizaram uma análise de dados do ano de 2008 de 52 entre os 65 Parnas existentes, obtidos com a Coordenação Geral de Regularização Fundiária do ICMBio $^{83}$. Segundo os autores:

De qualquer forma, os dados do ICMBio destacam a desanimadora informação de que nenhum PN [parque nacional] é considerado regularizado pelo órgão [Tabela 8]. Dos 52 parques para os quais valem os dados, 58\% não estão regularizados e $42 \%$ estão apenas parcialmente regularizados. Esses dados são incongruentes com as informações da Tabela 3 [corresponde a nossa Tabela 7], pois eles apontam que 14 unidades estão $100 \%$ regularizadas. $\mathrm{Na}$ verdade, essa incongruência ressalta na própria Tabela 3 [corresponde a nossa Tabela 7], pois, entre as 14 unidades $100 \%$ regularizadas, seis não dispunham de levantamento fundiário. Portanto, se esses PNs não foram nem sequer objeto de estudos fundiários, não faz sentido a informação sobre a ausência de pendências fundiárias em seus limites (ROCHA; DRUMMOND; GANEM, 2010, p. 215).

Tabela 8 - Situação de 52 parques nacionais brasileiros em relação ao grau de regularização fundiária (2008)

\begin{tabular}{l|c}
\hline \multicolumn{1}{c|}{ GRAU DE REGULARIZAÇÃO FUNDIÁRIA } & NÚMERO E \% DE PARQUES NACIONAIS \\
\hline Totalmente regularizado & $0 \quad(0 \%)$ \\
Parcialmente regularizado & $30(58 \%)$ \\
Não-regularizado & $22(42 \%)$ \\
TOTAL & $52(100 \%)$ \\
\hline
\end{tabular}

Fonte: ICMBio (2008 apud ROCHA; DRUMMOND; GANEM, 2010).

Para Rocha, Drummond e Ganem (2010), essas incoerências talvez se expliquem pela adoção de critérios diferentes de regularização fundiária, ao longo do tempo, pelos diferentes setores do Ibama e, mais recentemente, do ICMBio. De acordo com os autores, a confrontação desses dados reforça a "observação sobre a falta de dados confiáveis que permitam um

\footnotetext{
83 “A Coordenação não dispunha de dados relativos a 13 PNs [parques nacionais] criados entre 2001 e 2008. Da mesma forma, não constam informações pormenorizadas acerca da área regularizada e a regularizar de cada PN. Embora o Ibama tenha se preocupado mais sistematicamente, após a aprovação da Lei do Snuc, com a existência de comunidades e atividades produtivas nas áreas selecionadas para criação de novas unidades, isso não redundou na elaboração de estudos prévios completos acerca da situação fundiária das áreas onde se pretende criar PNs, de modo a evitar conflitos. É prudente esperar que os resultados finais dos levantamentos demonstrem a existência de problemas fundiários nos PNs mais novos, semelhantes aos das unidades antigas" (ROCHA; DRUMMOND; GANEM, 2010, p. 215).
} 
diagnóstico preciso acerca da situação fundiária dos PNs [parques nacionais]" (ROCHA; DRUMMOND; GANEM, 2010, p. 215).

Finalmente, para contextualizar a situação fundiária dos Parnas brasileiros (inclusive a precariedade dos dados disponíveis), Rocha, Drummond e Ganem (2010) apresentam os dados do MMA (2005 apud ROCHA; DRUMMOND; GANEM, 2010) acerca do grau de regularização fundiária das sete categorias de UC cujo domínio deve ser exclusivamente público (Tabela 9).

Tabela 9 - Situação fundiária das UCs federais brasileiras de domínio público, por categoria, em 2005

\begin{tabular}{c|c|c|c|c|c}
\hline Categoria & $\begin{array}{c}\text { Número de } \\
\text { unidades } \\
\text { cadastradas }\end{array}$ & Regularizadas & $\begin{array}{c}\text { Parcialmente } \\
\text { regularizadas }\end{array}$ & $\begin{array}{c}\text { Não } \\
\text { regularizadas }\end{array}$ & $\begin{array}{c}\text { Sem } \\
\text { informação }\end{array}$ \\
\hline Estação ecológica & 31 & 0 & 20 & 10 & 1 \\
\hline Parque nacional & 57 & 0 & 18 & 34 & 5 \\
\hline Reserva biológica & 27 & 1 & 3 & 13 & 10 \\
\hline Floresta nacional & 70 & 0 & 0 & 0 & 70 \\
\hline $\begin{array}{c}\text { Reserva de } \\
\text { desenvolvimento } \\
\text { sustentável }\end{array}$ & 1 & 0 & 0 & 0 & 1 \\
\hline Reserva de fauna & 0 & 0 & 0 & 0 & 0 \\
\hline Reserva extrativista & 43 & 3 & 2 & 27 & 11 \\
\hline Total & 229 & 4 & 43 & 84 & 98 \\
\hline
\end{tabular}

Fonte: MMA (2005 apud ROCHA; DRUMMOND; GANEM, 2010).

Da área total das UCs do país, cerca de 70\% (107 milhões ha) estão em categorias de UCs que preveem a posse e/ou domínio público (MMA, 2005 apud ROCHA; DRUMMOND; GANEM, 2010). Desse universo de área, de acordo com os dados do ano de 2005 (do MMA), Rocha, Drummond e Ganem (2010, p. 215) evidenciam que, "do total de UCs cadastradas[,] aproximadamente $44 \%$ destas não se tem informações e somente 4 das UCs de domínio público está regularizada, ou seja 1,74\%,18\% parcialmente regularizada, e 37\% não regularizada".

Rocha, Drummond e Ganem (2010, p. 217-218) afirmam que a regularização dos Parnas é assunto de alta complexidade:

Envolve muitos interesses, vultosos recursos financeiros, terras usadas para a produção agropecuária, comunidades rurais de diversos tipos, fluxos de visitação, empreendimentos turísticos etc. Talvez o mais grave problema seja o contexto historicamente consolidado de especulação e de apossamento ilegal de terras públicas. Isso configura um quadro de "indústria das desapropriações", que envolve procedimentos duvidosos e indenizações milionárias. Por outro lado, a questão fundiária tem peculiaridades que estimulam a inércia do poder público no seu trato, agravando os problemas. 
As pendências na regularização fundiária dos PNs [parques nacionais], apesar dos prejuízos causados, normalmente não inviabilizam a existência das unidades e o cumprimento parcial de suas funções. Curiosamente, um PN pode conviver com elas por períodos relativamente longos sem que haja conflitos agudos, mas também sem que se alcancem soluções definitivas. Assim, os problemas fundiários não alcançam necessariamente uma grande repercussão pública, nem geram forte mobilização social que pressione o órgão gestor a resolvê-los. Isto suscita a convivência prolongada com situações irregulares e uma postura complacente ou postergadora dos órgãos administradores. Outro fator que contribui para a inércia no trato da questão fundiária dos PNs é a baixa probabilidade de que a sua eventual resolução gere dividendos políticos para os gestores dos órgãos incumbidos de tratar das UCs. Os prazos para a obtenção de resultados significativos são relativamente longos, contrapostos aos períodos relativamente curtos dos cargos de direção. Criar novas UCs rende maior visibilidade e dividendos do que resolver os complexos problemas das UCs existentes. Novas UCs enriquecem o currículo do administrador. Além do mais, a resolução dos problemas fundiários, via de regra, gera atritos e desgaste com pessoas influentes, que se mobilizam jurídica e politicamente para resistir às ações que os prejudicam. Ocorre ainda a possibilidade de atritos não-desejados com as comunidades vizinhas das UCs. Essas situações levam à anulação recíproca das forças sociais envolvidas na questão e ajudam a explicar porque o problema nunca foi objeto de medidas sistemáticas, firmes e eficazes.

Embora não haja um levantamento fundiário definitivo das UCs de posse e/ou domínio público em âmbito federal, o ICMBio (apud TCU, 2013, p. 58) estima um custo de R\$7,1 bilhões para desapropriar aproximadamente 5,4 milhões ha referentes às terras pendentes de desapropriação. Considerando o desembolso anual médio em regularização fundiária de UCs federais realizado entre 2009 e 2012, o ICMBio demoraria aproximadamente 102 anos para concluir a regularização de UCs federais (TCU, 2013).

A Tabela 10 reúne as informações sobre o quantitativo em hectare de áreas privadas em UCs federais, o custo (em R \$) de indenização por hectare e o custo total ( $R$ \$) das indenizações por hectare por bioma. O maior número de propriedades privadas no interior de UCs federais encontra-se na Amazônia, totalizando quase 3 milhões ha. Esse montante significativamente maior de privados nas UCs do bioma Amazônia decorre do maior número de UCs nessa região. Na sequência, o Cerrado totaliza 1.676.925 ha, seguido da Mata Atlântica com 652 mil ha. A Caatinga e o Pampa possuem, respetivamente, 103 e 35 mil ha de áreas privadas em UCs federais. 
Tabela 10 - Custo estimado para indenização de terras privadas no interior de UCs federais

\begin{tabular}{l|r|r|r}
\hline \multicolumn{1}{c|}{ Bioma } & $\begin{array}{c}\text { Terras privadas no } \\
\text { interior de UC (ha) }\end{array}$ & $\begin{array}{c}\text { Custo de } \\
\text { indenização por } \\
\text { hectare (R\$) }\end{array}$ & $\begin{array}{c}\text { Custo total das } \\
\text { indenizaçóes de terras } \\
\text { privadas (R\$) }\end{array}$ \\
\hline Amazônia & 2.970 .592 & 800 & 2.376 .473 .600 \\
\hline Caatinga & 102.696 & 2.000 & 205.392 .000 \\
\hline Cerrado & 1.676 .925 & 1.500 & 2.515 .387 .500 \\
\hline Pampa & 35.826 & 2.000 & 71.652 .000 \\
\hline Mata Atlântica & 652.781 & 3.000 & 1.958 .343 .000 \\
\hline Marinho Costeiro & 633 & 2.000 & 7.128 .514 .100 \\
\hline Total & 5.439 .453 & 750.389 & \\
\hline
\end{tabular}

Fonte: TCU (2013).

O custo total dessas indenizações para se regularizar essas áreas está na ordem de $\mathrm{R} \$$ 7.128.514.100, conforme a Tabela 10.

Se, por um lado, o Estado defronta-se com um expressivo passivo de regularização fundiária, por outro, defronta-se com parcos recursos destinados para essa finalidade.

Medeiros e Young (2011) afirmam que o aumento da área destinada à conservação não foi acompanhado pelo incremento de recursos financeiros a serem alocados. Enquanto o sistema cresce, seus recursos financeiros seguem em direção oposta (GODOY; LEUZINGER, 2015).

Segundo o ICMBio (2017), a área regularizada pela instituição em dez anos de sua gestão das UCs federais é de 14 milhões ha. No entanto, esse montante se refere também a áreas que foram transferidas por outras esferas do poder público para a administração do ICMBio, ou seja, são áreas que já estavam sob domínio dos poderes federal ou estadual e que foram, como determina a própria criação do ICMBio, cedidas a esse órgão. De áreas privadas indenizadas e efetivamente desapropriadas por meio de recursos da regularização ou compensação ambiental, o ICMBio regularizou apenas $151 \mathrm{mil} \mathrm{ha.}$

Dados recentes encontrados ${ }^{84}$ sobre as terras dentro de UCs de proteção integral carecendo de regularização fundiária por falta de indenização de proprietários rurais e posseiros, do TCU (2013, p. 58), estão presentes na Tabela 11 e apontam que, na esfera federal, esse passivo rondava os 5,5 milhões ha.

\footnotetext{
${ }^{84}$ Embora noticiado o lançamento no site do ICMBio em 2015, não foi possível achar página ou instruções de acesso ao Sistema de Informações sobre Consolidação Territorial de UCs Federais (SIGTerra), que deveria possibilitar o levantamento do passivo fundiário do órgão e da evolução do processo de regularização fundiária das UCs federais por ele administradas (ICMBIO, 2015). O sistema sequer se encontra na lista disponível no site do ICMBio, no endereço: <http://www.icmbio.gov.br/portal/sistemas1>; acesso em: 01 dez. 2017.
} 
Tabela 11 - Pendências de regularização fundiária das UCs federais

\begin{tabular}{l|r|r|r|r}
\hline \multicolumn{1}{|c|}{ Bioma } & \multicolumn{1}{c|}{$\begin{array}{c}\text { Terras } \\
\text { privadas } \\
\text { (Mha) }\end{array}$} & $\begin{array}{c}\text { Área do } \\
\text { bioma } \\
\text { (Mha) }\end{array}$ & $\begin{array}{c}\text { \% de terras } \\
\text { privadas } \\
\text { pendente de } \\
\text { regularização no } \\
\text { bioma }\end{array}$ & $\begin{array}{c}\text { \% de terras privadas } \\
\text { pendentes de } \\
\text { regularização no } \\
\text { bioma em relação ao } \\
\text { total das UCs }\end{array}$ \\
\hline Amazônia & 2,971 & 58,718 & $5,10 \%$ & $54,60 \%$ \\
\hline Caatinga & 0,103 & 4,001 & $2,60 \%$ & $1,90 \%$ \\
\hline Cerrado & 1,677 & 5,254 & $31,90 \%$ & $0,80 \%$ \\
\hline Pampa & 0,036 & 3,578 & $1 \%$ & $0,70 \%$ \\
\hline $\begin{array}{l}\text { Mata } \\
\text { Atlântica }\end{array}$ & 0,653 & 3,021 & $21,60 \%$ & $0 \%$ \\
\hline $\begin{array}{l}\text { Marinho } \\
\text { Costeiro }\end{array}$ & 0,001 & 0,320 & $0,20 \%$ & $12 \%$ \\
\hline Pantanal & 0,000 & 0,147 & $0 \%$ & $0 \%$ \\
\hline Total & 5,440 & 75,039 & $7,20 \%$ & $0.00 \%$ \\
\hline
\end{tabular}

Fonte: ICMBio (apud TCU, 2013).

Dados de 2013 do TCU também mostram (Tabela 12) que, no ritmo recente de regularização fundiária, inclusos recursos do Orçamento Geral da União (OGU), bem como outros recursos, levaríamos mais de um século para completar o processo de regularização fundiária das UCs. Vale ressaltar que, de acordo com a Tabela 12, 58\% dos recursos utilizados para esse fim, no período de 2009 a 2012, vieram de compensações ambientais, portanto recursos pontuais e externos ao OGU, gerando dificuldades de planejamento e incertezas quanto à continuidade desse processo a longo prazo. 
Tabela 12 - Recursos financeiros aplicados em regularização fundiária entre 2009 e 2012

\begin{tabular}{l|r|c}
\hline \multicolumn{1}{c|}{ Ano } & $\begin{array}{c}\text { Valor aplicado } \\
\text { (R\$) }\end{array}$ & Origem do recurso \\
\hline $2009-2011$ & 162.763 .218 & $\begin{array}{c}\text { Compensação } \\
\text { ambiental }\end{array}$ \\
\hline 2009 & 0 & OGU \\
\hline 2010 & 50.997 .609 & OGU \\
\hline 2011 & 51.327 .046 & OGU \\
\hline 2012 & 2.569 .444 & OGU \\
\hline 2012 & 12.075 .534 & $\begin{array}{c}\text { Compensação } \\
\text { ambiental }\end{array}$ \\
\hline Total (A) & 279.732 .851 & \\
\hline Média anual (B) = (A) / 4 & 69.933 .213 & \\
\hline $\begin{array}{l}\text { Estimativa de recursos para } \\
\text { desapropriações (C) }\end{array}$ & $7.128 .514 .100^{*}$ & \\
\hline $\begin{array}{l}\text { Tempo estimado de pagamento } \\
\text { das indenizações (D) = C/B }\end{array}$ & 101,9 anos & \\
\hline
\end{tabular}

Fonte: TCU (2013, p. 60).

Uma análise sobre os valores pagos para a regularização fundiária com os recursos do OGU atesta a necessidade de se ter outros instrumentos capazes de apoiar a regularização fundiária das UCs.

Considerando esse fato, fontes alternativas de recursos que não integram o orçamento público têm sido indicadas para suprir a lacuna financeira e atender à política de criação e implantação de unidades de conservação. Afora as dotações provenientes do orçamento público, têm sido fontes secundárias de receitas para as unidades doações originárias de projetos de cooperação internacional, algumas doações nacionais e a compensação ambiental, prevista no art. 36 da Lei $n^{\circ}$ 9.985, de 2000 (GODOY; LEUZINGER, 2015, p. 227).

É ainda relevante notar que $63 \%$ dos recursos utilizados para a regularização fundiária no período entre 2009 e 2012 foram oriundos da compensação ambiental paga por empresas para a obtenção de licenças ambientais. Esse pagamento visa a incorporar os custos sociais e ambientais da degradação gerada por determinados empreendimentos em seus custos globais. Portanto a regularização tem sido dependente da existência de empreendimentos que acarretam mais riscos de danos (ARAÚJO; BARRETO, 2015).

"Contar, prioritariamente, com recursos derivados da realização de atividades real ou potencialmente poluidoras, como as geradoras de compensação ambiental, ou com as multas ambientais, por exemplo, poderia evidenciar uma contradição dentro da política pública" (GODOY; LEUZINGER, 2015, p. 229). “A dependência exclusiva de determinadas fontes, 
sobretudo as que têm por fundamento atos ilícitos ou impactantes ao meio ambiente, pode gerar efeitos contraditórios, diminuindo a efetividade da política pública" (GODOY; LEUZINGER, 2015, p. 230).

Araújo e Barreto (2015) apresentam exemplos de fontes de recursos financeiros para UCs: visitação pública, concessões florestais, fundos públicos, cooperação internacional, compensação ambiental, cobrança pelos serviços hídricos prestados por UCs (art. 47 da Lei no 9.985, de 18 de julho de 2000) ${ }^{85}$, recursos financeiros advindos da exploração dos serviços ecossistêmicos das UCs de empresa de abastecimento de água ${ }^{86}$, aproveitamento dos recursos genéticos (bioprospecção) e extrativismo, cogestão (ou gestão compartilhada de UCs) e ICMS Ecológico.

Araújo e Barreto (2015, p. 7), ao avaliarem os desafios e as oportunidades para garantir recursos financeiros para a regularização fundiária de UCs, afirmam que

[...] o custo da regularização fundiária de UCs seria reduzido se nas ações judiciais para retomada de terras públicas se adotasse o entendimento do Superior Tribunal de Justiça ${ }^{87}$, segundo o qual quem ocupa área pública não tem direito a indenização por benfeitorias que tenha construído, mesmo que a ocupação tenha ocorrido de boa-fé. Além de desonerar o poder público da obrigação de indenizar ocupantes de terra pública, esse entendimento desestimularia invasões e construções ilegais em espaços públicos.

Araújo e Barreto (2015, p. 7) também argumentam que há recursos disponíveis para custear a implementação das UCs, além de formas eficazes de geri-los, por exemplo,

[...] a venda de $8 \%$ das glebas federais não destinadas na Amazônia (38 milhões de hectares) seria suficiente para custear toda a regularização de UCs federais na região. Ou, ainda, a arrecadação de $11 \%$ do valor total das multas ambientais emitidas pelo Instituto Brasileiro do Meio Ambiente e dos Recursos Naturais Renováveis (Ibama) entre 2009 e 2013 (R\$ 1,7 bilhão) cobriria $100 \%$ da regularização fundiária das UCs federais na Amazônia. Os governos federal e estaduais deveriam agilizar o uso de recursos de compensação por meio de organizações da sociedade civil de interesse público (Oscip) que permitem mais agilidade e flexibilidade em contratações e compras, ao mesmo tempo que mantêm a prestação de contas públicas. A

\footnotetext{
85 “O órgão ou empresa, público ou privado, responsável pelo abastecimento de água ou que faça uso de recursos hídricos, beneficiário da proteção proporcionada por uma unidade de conservação, deve contribuir financeiramente para a proteção e implementação da unidade, de acordo com o disposto em regulamentação específica" da lei do SNUC, no art. 47 (apud OLIVEIRA, 2010, p. 170).

86 “O órgão ou empresa, público ou privado, responsável pela geração e distribuição de energia elétrica, beneficiário da proteção oferecida por uma unidade de conservação, deve contribuir financeiramente para a proteção e implementação da unidade, de acordo com o disposto em regulamentação específica" da lei do SNUC no art. 48 (apud OLIVEIRA, 2010, p. 170). Porém, no Brasil, apesar de existir dispositivo legal expresso sobre o dever de contribuir para a manutenção da unidade de conservação responsável pela proteção usufruída, até hoje não há a respectiva regulamentação, permitindo aos órgãos e empresas esquivarem-se de tal contribuição.

87 "Ver decisões de 2008 e 2009 em recurso especial (Resp): REsp 863.939 - RJ (DJe 24.11.2008) e REsp 945.055

- DF (DJe 20.8.2009). Ver decisão da Segunda Turma do STJ ao julgar o recurso especial (REsp) 945.055 - DF (DJe 20.8.2009)" (ARAÚJO; BARRETO, 2015, p. 15).
} 
implementação dessas e outras recomendações depende de um compromisso de alto nível dos governos federal e estaduais e coordenação das várias instituições envolvidas.

Enquanto não ocorre o processo de regularização das UCs, elas vêm sofrendo riscos de desafetação ${ }^{88}$ e redução de limites de seu patrimônio natural protegido em razão de processos de urbanização, projetos desenvolvimentistas, expansão agrícola e pecuária.

A revisão e alteração dos limites das UCs ocorre por razões ambientais, políticas, sociais e econômicas e essa prática vem se tornando uma realidade. Entre 1995 e 2012, 2,8 milhões ha foram desafetados (ou seja, perderam status de UC) na Amazônia para regularizar ocupações. Dessas desafetações, $41 \%$ (1.138.765 ha) ocorreram entre 2010 e 2012, sendo os estados responsáveis por 93\% do total desafetado nesse período (MARTINS et al., 2014 apud ARAÚJO; BARRETO, 2015).

A vulnerabilidade das UCs decorre de falhas sistêmicas do poder público, segundo Araújo et al. (2017). Entre estas vulnerabilidades, os autores destacam:

i) a estratégia errática e limitada do governo, que consiste em mudar regras e enfraquecer a legislação ambiental conforme interesses de momento e em tolerar o desmatamento ilegal até 2030; ii) os escassos recursos humanos para gestão e a preocupante tendência de redução no número de analistas ambientais federais lotados na Amazônia, de 40\% no ICMBio (2010-2016) e de 33\% no Ibama (2009-2015); iii) os recursos financeiros insuficientes para realizar os investimentos necessários à implementação das UCs - somente as 16 UCs federais críticas deste estudo precisariam de $\mathrm{R} \$ 10,6$ milhões anuais, valor 3,26 vezes maior do que a média de recursos de investimento do ICMBio entre 2014 e 2016 para todo o país e 3,42 vezes maior do que o projetado para 2017; iv) a ineficácia na execução, que se revela na baixa aplicação de recursos financeiros disponíveis. Por exemplo, entre 2009 e 2014, o ICMBio executou apenas $35 \%$ dos $\mathrm{R} \$ 218$ milhões recebidos para compensação ambiental; na morosidade no combate a ocupações irregulares, que causa danos ambientais e sociais; e na baixa punição de criminosos ambientais e fundiários (ARAÚJO et al., 2017, p. 8-9).

Este capítulo teve como objetivo evidenciar o significado da consolidação territorial das UCs (entendida num processo mais amplo da regularização fundiária de suas áreas e a consolidação de seus limites) e os conflitos fundiários existentes desde o processo de sua criação, que se arrastam na sua implementação, impedindo a gestão desses espaços territoriais ambientalmente protegidos.

As dificuldades em se resolver a questão fundiária das UCs repercute nos demais instrumentos que também fazem parte e acompanham a criação dessas áreas, como a formação

\footnotetext{
${ }^{88}$ A desafetação (ou seja, a extinção da UC) ou a redução dos limites de uma UC só pode ser feita mediante lei específica.
} 
do Conselho Gestor, os planos de manejo e documentos anexos (como zoneamento ecológico e definição das zonas de amortecimento) e a manutenção de equipe técnica capacitada.

É a fragilidade da governança de terras do Brasil, principalmente da insegurança dos direitos de propriedades, que ocasiona as situações reveladas no passivo fundiário encontrado nas áreas das UCs.

Nesse cenário, a possibilidade da compensação de RL por doação de áreas em UCs de domínio público como forma de financiar a regularização fundiária das UCs, desonerando o Estado brasileiro, mostra-se, a princípio, uma alternativa.

O próximo capítulo analisará a oferta para a compensação de RL por doação de área de UC a partir dos dados do CAR e do Sigef para o Cerrado. No entanto, podemos, a partir da análise deste capítulo, concluir que existem sérios desafios para que realmente se efetive a consolidação territorial das UCs, sendo o mecanismo da compensação de RL por doação de área de UC somente um instrumento para agilizar a regularização fundiária das UCs. O real impacto desse mecanismo sobre a situação fundiária das UCs federais será objeto do próximo capítulo. 


\section{ANÁlise da OFERTA de Áreas PARA O MERCAdo DE TERras de COMPENSAÇÃO DE RESERVA LEGAL POR DOAÇÃO DE ÁREA DE UNIDADE DE CONSERVAÇÃO DE DOMÍNIO PÚBLICO NO BIOMA CERRADO}

Este capítulo se dedica à apresentação da metodologia utilizada neste trabalho e seus principais resultados. Também se dedica aos argumentos sobre a escolha do bioma Cerrado como estudo de caso a partir de sua descrição socioeconômica e ambiental, que justificam a escolha deste bioma como objeto de análise da oferta de suas terras para o mercado de compensação de RL por doação de área das UCs de domínio público para o órgão gestor destas áreas.

Os itens subsequentes trazem os aspectos metodológicos dos indicadores analisados de forma geral (item 6.1). As características do bioma Cerrado que justificam sua escolha como estudo de caso estão no item 6.2. Resumidamente, a escolha do estudo de caso do bioma Cerrado ocorre principalmente devido às características deste bioma relacionadas aos fatores econômicos da região, como uma área de expansão da fronteira agrícola do país.

Os principais resultados estão descritos no item 6.4 por cada categoria de UC de domínio público. Já no item 6.5 é realizada uma análise dos indicadores totais das ofertas atuais e potenciais de terras para o mercado de compensação de RL por doação de área de UC e as áreas sem cadastros destas UCs.

\subsection{Metodologia de análise do estudo de caso das UCs de domínio público do bioma Cerrado}

Para a análise empreendida nesta tese, serão contabilizadas a oferta atual e a oferta potencial de áreas (em hectares) (até março de 2018) pendentes de regularização fundiária no interior das UCs de domínio público federais, estaduais e municipais no bioma Cerrado que tenham declarado a posse ou propriedade da área.

Estas informações serão provenientes das seguintes fontes de dados: 1) propriedades e posses rurais autodeclaradas no CAR e 2) áreas particulares certificadas no Sigef pelo Incra que são aquelas que possuem matrícula registrada no Cartório de Registro de Imóveis, dessa forma, são propriedades rurais que podem ser ofertadas no mercado de compensação de RL analisado. Também colaboram com estes indicadores tanto as informações do CNUC relacionadas à situação fundiária de cada UC de domínio público do Cerrado, ou seja, se estas estão totalmente, parcialmente ou não regularizadas, como as informações sobre a existência 
ou não de ocupações humanas nas áreas das UCs. Vale acrescentar que o CNUC não possui informações fundiárias e de ocupação para todas as UCs do Cerrado, ficando um montante considerável de UCs sem constar dessas informações.

As áreas particulares cadastradas (no interior das UCs de domínio público) no Sigef e certificadas pelo Incra são aquelas que realmente estão aptas para serem ofertadas no mercado de compensação de RL por doação de área de UC. No entanto estas áreas possuem sobreposição de áreas entre si e com demais tipos de terras, como as áreas certificadas públicas no Sigef, as terras indígenas e os assentamentos.

O item 6.3 apresenta mais detalhadamente o que foi realizado para se chegar no cálculo das ofertas atual e potencial de terras, que são respectivamente as áreas particulares certificadas no Sigef e as áreas cadastradas no CAR, ambas sem sobreposição com áreas de outros domínios (como terra pública certificada no Sigef, assentamentos e terras indígenas).

Para identificação das UCs que possuem em seu interior áreas particulares, terras indígenas e outras terras públicas, gerando algum conflito fundiário e litígios, utilizou-se as camadas de dados individuais no formato shapefile dos limites de UCs, no bioma Cerrado, das terras indígenas e dos assentamentos rurais e os dados de imóveis rurais disponíveis no CAR e no Sigef. As camadas de dados foram processadas individualmente e depois sobrepostas no ambiente de SIG. Os itens subsequentes explicam este processamento de dados.

Após a discussão sobre a metodologia utilizada neste trabalho, o item 6.4 traz os principais resultados dos indicadores de oferta atual de terras (áreas particulares certificadas no Sigef sem sobreposição de áreas de outros domínios), áreas de oferta potencial (áreas cadastradas no CAR sem sobreposição de áreas de outros domínios) e áreas sem cadastros nestas UCs. Estes indicadores foram analisados por categoria de UC de domínio público, ou seja, parques nacionais, estações ecológicas, reservas extrativistas, florestas nacionais e reservas biológicas.

O item 6.5 dedica-se à análise dos indicadores totais das ofertas atuais e potenciais de terras para o mercado de compensação de RL por doação de área de UC e as áreas sem cadastros destas UCs.

\subsection{Descrição do bioma Cerrado: fatores ambientais e econômicos da escolha da área de estudo}

No Brasil, existem seis grandes biomas naturais, sendo o Cerrado um deles. Além disso, o Cerrado é o segundo maior bioma em extensão territorial, ocupando 2.036.448 quilômetros 
quadrados (203.644.800 ha), ou seja, cerca de 24\% do território brasileiro (IBGE, 2004). Outros autores apresentam números próximos para a estimativa da área territorial do Cerrado: 1,8 milhões de quilômetros quadrados (BRANNSTROM et al., 2007, p. 579), 21\% do território brasileiro (BORLAUG, 2002).

O clima dessa região é estacional, em que um período chuvoso, que dura de outubro a março, é seguido por um período seco, de abril a setembro. A precipitação média anual é de 1.500 milímetros, e as temperaturas são geralmente amenas ao longo do ano, entre $22^{\circ} \mathrm{C}$ e $27^{\circ} \mathrm{C}$ em média. Os remanescentes de Cerrado que existem nos dias de hoje desenvolveram-se sobre solos muito antigos, intemperizados, ácidos, depauperados de nutrientes, mas que possuem concentrações elevadas de alumínio. Para torná-los produtivos para fins agrícolas, aplicam-se fertilizantes e calcário aos solos do Cerrado. A pobreza dos solos, portanto, não constituiu obstáculo para a ocupação de grandes extensões de terra pela agricultura moderna, especialmente a cultura da soja, um dos principais itens da pauta de exportações do Brasil, e as pastagens plantadas (KLINK; MACHADO, 2005, p. 148).

Figura 2 - Mapa dos principais biomas brasileiros

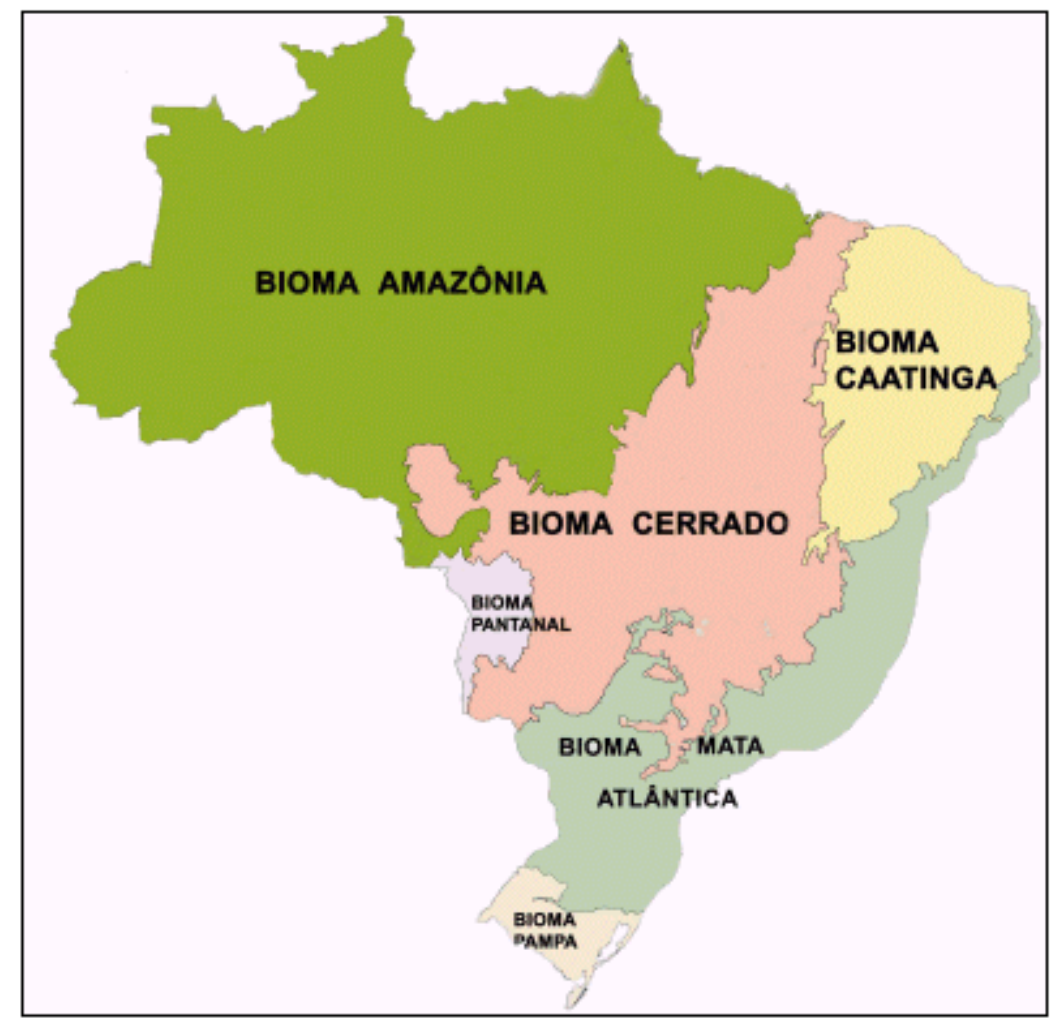

Fonte: IBGE (2004). 
O bioma Cerrado está espalhado por 12 dos 26 estados brasileiros, com diferentes proporções em relação à área de cada estado (Tabela 13). Os principais estados com grandes áreas de Cerrado são Goiás, Mato Grosso e Mato Grosso do Sul, além da região de Cerrado dos estados do Maranhão, Tocantins, Piauí e Bahia (região conhecida pelo acrônimo Matopiba).

Tabela 13 - Porcentagem de bioma Cerrado por estado brasileiro

\begin{tabular}{l|c}
\hline \multicolumn{1}{c|}{ UFs } & Cerrado (\%) \\
\hline Acre & \\
\hline Alagoas & \\
\hline Amapá & 27 \\
\hline Amazonas & \\
\hline Bahia & 100 \\
\hline Ceará & \\
\hline Distrito Federal & 97 \\
\hline Espírito Santo & \\
\hline Goiás & 65 \\
\hline Litígio Piauí-Ceará & 39 \\
\hline Maranhão & 61 \\
\hline Mato Grosso & 57 \\
\hline Mato Grosso do Sul & \\
\hline Minas Gerais & \\
\hline Pará & \\
\hline Paraíba & \\
\hline Paraná & \\
\hline Pernambuco & \\
\hline Piauí & \\
\hline Rio de Janeiro & \\
\hline Rio Grande do Norte & \\
\hline Rio Grande do Sul & \\
\hline Rondônia & \\
\hline Roraima & \\
\hline Santa Catarina & \\
\hline São Paulo & \\
\hline Sergipe & \\
\hline Tocantins & \\
\hline
\end{tabular}

Fonte: IBGE (2004).

É consenso na comunidade acadêmica que a expansão da fronteira agrícola brasileira nas quatro últimas décadas se deu pela incorporação do bioma Cerrado na produção e pela aproximação dos limites da região amazônica (Figura 3). Este movimento traz, por um lado, um aumento do dinamismo econômico nestas regiões e, por outro lado, uma preocupação com relação à conservação ambiental. 
Figura 3 - A expansão da fronteira agrícola no Brasil e no bioma Cerrado em diferentes períodos

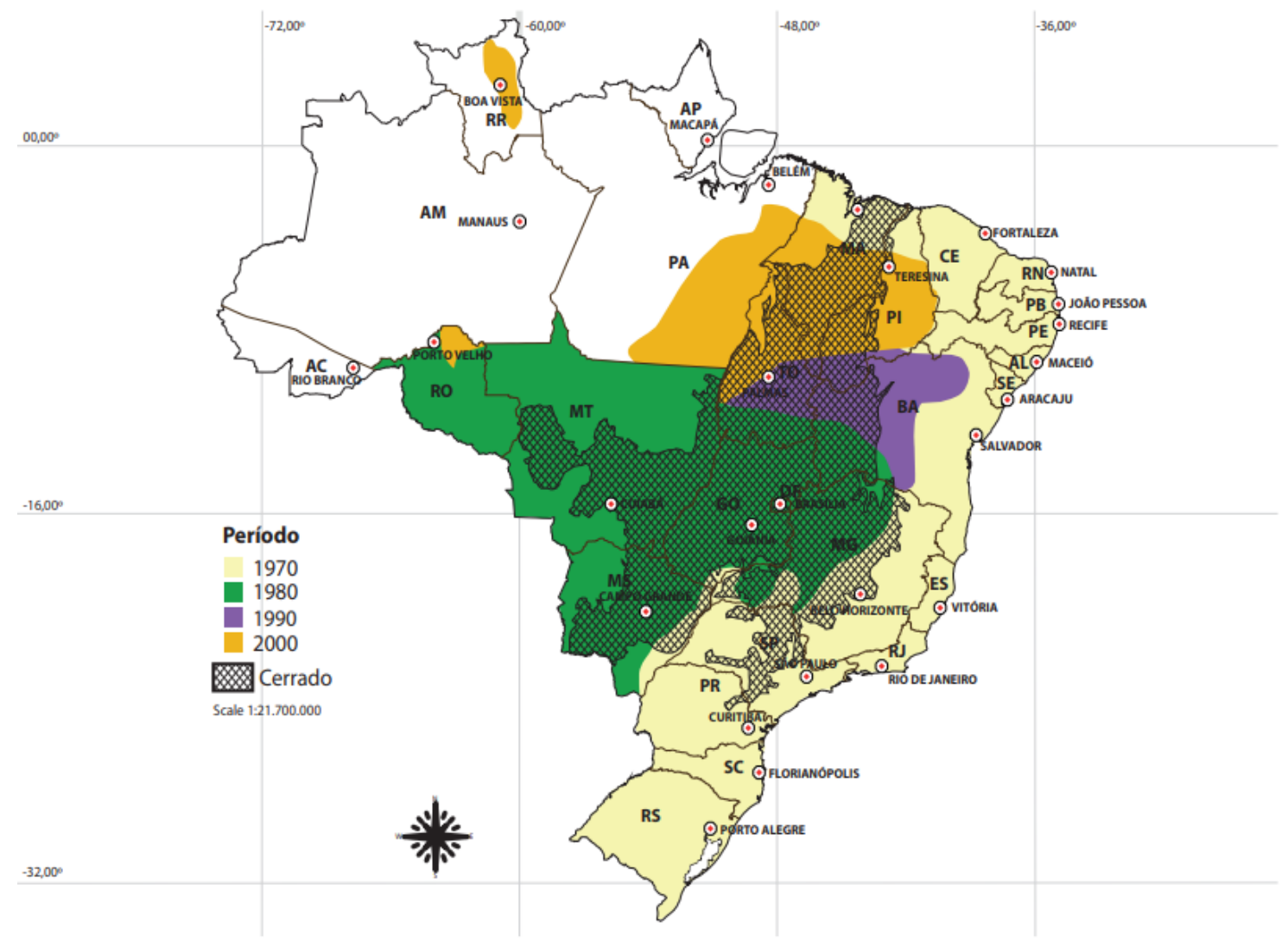

Fonte: Vieira Filho (2016, p. 13).

Estima-se que metade dos 2 milhões de quilômetros quadrados de Cerrado original foram transformados em pastagens plantadas, culturas anuais e outros tipos de uso. Além disso, outros 500 mil quilômetros quadrados são ocupados por monoculturas, sendo que a soja representa 63\% desta área (KLINK; MACHADO, 2005; SPAROVEK et al., 2010).

Tabela 14 - Uso da terra no bioma Cerrado em relação à área central do bioma

\begin{tabular}{l|r|r}
\multicolumn{1}{c|}{ Uso da terra } & \multicolumn{1}{c|}{ Área (ha) } & \% área central do bioma \\
\hline Áreas nativas & 70.581 .162 & $44,53 \%$ \\
\hline Pastagens plantadas & 65.874 .145 & $41,56 \%$ \\
\hline Agricultura & 17.984 .719 & $11,35 \%$ \\
\hline Florestas & 116.760 & $0,07 \%$ \\
\hline Áreas urbanas & 3.006 .830 & $1,90 \%$ \\
\hline Outros & 930.304 & $0,59 \%$ \\
\hline Total & 158.493 .921 & \\
\hline
\end{tabular}

Fonte: Klink e Machado (2005). 
Em termos ambientais, a destruição dos ecossistemas que constituem o Cerrado continua de forma acelerada: um estudo que utilizou imagens do satélite Modis do ano de 2002 conclui que $55 \%$ do Cerrado já foi desmatado ou transformado pela ação humana, o que equivale a 880 mil quilômetros quadrados, ou seja, três vezes a área desmatada na Amazônia brasileira (MACHADO et al., 2004). Um dos motivos para tanto é justamente a diferença de tratamento do Código Florestal para os biomas: no Cerrado, é exigido apenas entre $20 \%$ e 35\% de RL, já na Amazônia a exigência é de $80 \%$.

O Cerrado tem menos de $10 \%{ }^{89}$ de sua área protegida com UCs integral, sustentável ou terras indígenas - sendo que apenas 2,2\% destas são de proteção integral (Tabela 15).

Tabela 15 - Cobertura das áreas protegidas nos principais biomas brasileiros - UCs integral, de uso sustentável e terras indígenas

\begin{tabular}{l|r|r|r|r}
\hline \multicolumn{1}{c|}{ Bioma } & Área $\left.\mathbf{( k m}^{\mathbf{2}}\right)$ & \multicolumn{1}{c|}{$\begin{array}{c}\text { Unidades de } \\
\text { proteção integral a,b }\end{array}$} & $\begin{array}{c}\text { Unidades de uso } \\
\text { sustentável }\end{array}$ & Terras indígenas a $^{\mathbf{a}, \mathbf{c}}$ \\
\hline Cerrados & 2.116 .000 & 2,2 & 1,9 & 4,1 \\
\hline $\begin{array}{l}\text { Floresta Amazônica } \\
\text { (incluindo ecótonos) }\end{array}$ & 4.239 .000 & 5,7 & 7,7 & 17,7 \\
\hline Mata Atlântica & 1.076 .000 & 1,9 & 0,11 & 0,15 \\
\hline Pantanal & 142.500 & 1,1 & 0 & 2,4 \\
\hline Caatinga & 736.800 & 0,8 & 0,11 & 0,15 \\
\hline Brasil & 8.534 .000 & 3,5 & 3,4 & 8,8 \\
\hline
\end{tabular}

Fonte: Klink e Machado (2005, p. 150).

Notas: ${ }^{a}$ Valores apresentados em porcentagens da área original do bioma.

${ }^{\mathrm{b}} \mathrm{UCs}$ estaduais e federais combinadas.

Retornando à questão da rápida expansão agrícola no Cerrado, Rezende (2002) propõe que esse dinamismo, concentrado nas atividades de grãos e pecuária, deve-se ao baixo preço da terra nessas regiões vis-à-vis as demais regiões agrícolas do Brasil e do exterior. Estes baixos preços são explicados em função da maior distância em relação aos mercados consumidores, às limitações dos recursos naturais (extremo rigor do período seco) e às inovações tecnológicas que tornaram possível que a terra de boa qualidade se tornasse abundante - mediante a sua "produção" a partir de terras inferiores.

Internamente, vê-se a discrepância dos preços de terras de lavoura no Mato Grosso comparado com outros estados de tradição agrícola: os preços das terras em São Paulo e Paraná

\footnotetext{
${ }^{89}$ Em relatório mais recente (MESQUITA et al., 2009, p. 8), estima-se que "o bioma Cerrado possui apenas 7,44\% de sua área protegida por unidades de conservação, federais, estaduais e municipais, sendo que aproximadamente 2,91\% do Cerrado é protegida na forma de unidades de conservação de proteção integral, tais como os parques nacionais".
} 
flutuaram em torno do múltiplo de quatro a seis vezes o preço da terra de lavoura em Mato Grosso, enquanto o preço de terra de lavoura no Rio Grande do Sul esteve sempre acima do triplo do preço de terra de lavoura em Mato Grosso (Figura 4).

Figura 4 - Razão entre os preços de terra de lavoura de São Paulo, Paraná e Rio Grande do Sul, 19702000

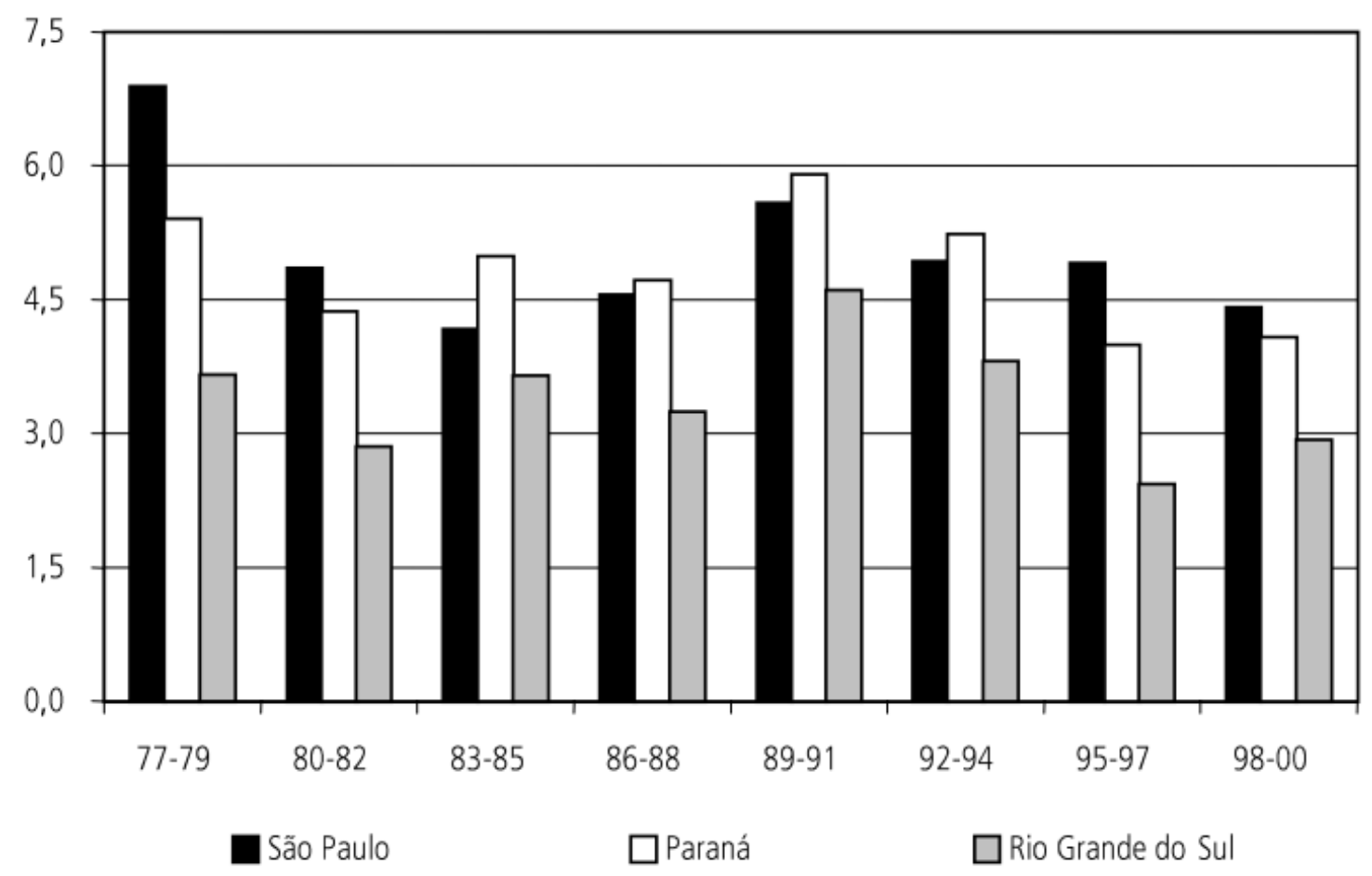

Fonte: Rezende (2002, p. 4).

Um dos fatores explicativos deste preço mais baixo deriva da forte restrição ao uso da terra para atividades que dependem da umidade do solo durante o período seco do Cerrado assim, esta restrição faz com que o custo de oportunidade da terra utilizada nas atividades de grãos e pecuária extensiva seja praticamente zero, aumentando a competitividade destas atividades na região (REZENDE, 2002, p. 4).

Outra forma de atestar o baixo preço da terra como explicativo para tornar competitiva a atividade com grãos é comparando o custo de produção (no caso, soja) no Mato Grosso e nos EUA (estado de Illinois) e analisando o custo da terra nesta comparação. Se nos EUA o custo da produção de soja por hectare é de US\$ 798, no Mato Grosso é de US\$ 386 - e a diferença do custo da terra é de US\$286,6 nos EUA contra US\$37,2 no Mato Grosso (REZENDE, 2002, p. 5). 
Além desta diferença estática de preços, existe ainda a valorização dinâmica das terras no Brasil. Por exemplo, no caso do Cerrado, houve um aumento real (descontada a inflação) de quase cinco vezes no preço das terras de Cerrado, no período de 2003 a 2016 (STEINWEG; KUEPPER; THOUMI, 2017, p. 2), o que aponta para um interesse crescente sobre essas áreas. Outro fator importante sobre a dinâmica dos preços das terras de Cerrado, conforme constatado em pesquisa recente (STEINWEG; KUEPPER; THOUMI, 2017, p. 3), é que este aumento real do preço das terras tem se descolado do aumento do preço das commodities geralmente produzidas na região. A Figura 5 ilustra esse argumento ao exibir a variação dos preços de terras em algumas regiões de Cerrado do Matopiba e, concomitantemente, as variações do preço internacional da soja - na figura é possível identificar claramente uma correlação entre o preço da soja e os preços de terra até 2013 e o descolamento posterior.

Figura 5 - Evolução dos preços de terra em locais selecionados do Matopiba versus evolução do preço internacional da soja (CBOT)

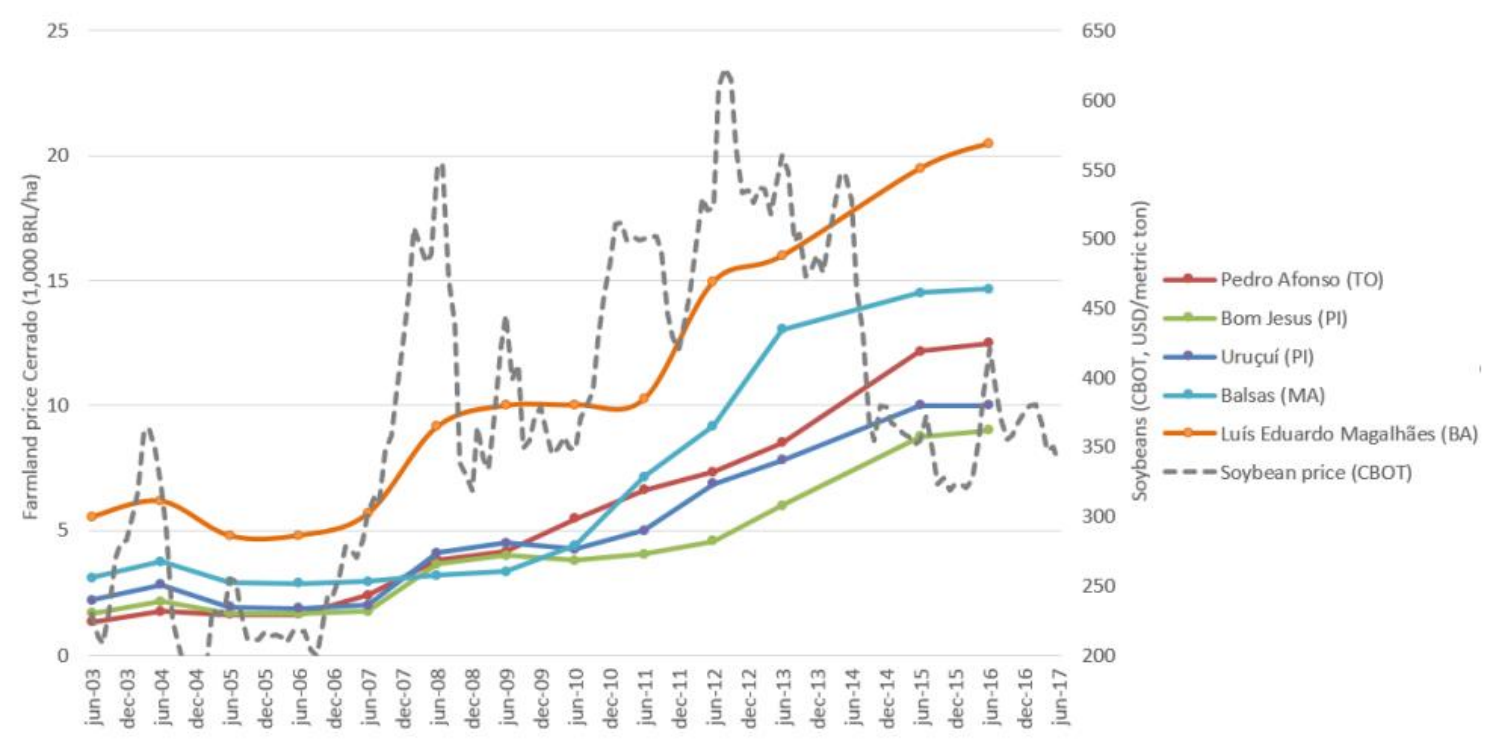

Fonte: Steinweg, Kuepper e Thoumi (2017, p. 3).

Dada a descrição do Cerrado e a especificidade da dinâmica de preços da região, podese analisar agora a relação entre a agricultura e legislação ambiental e seus efeitos no Cerrado levando em consideração nesta discussão as formas de conciliar a produção agrícola com a conservação ambiental neste bioma.

Conforme foi apresentado, o Cerrado é um dos biomas que mais tem sofrido pressão antrópica nas décadas recentes, e as tentativas de reduzir esta pressão ou regulá-la para 
minimizar os impactos nesses ecossistemas envolve diretamente a governança de terras e, mais especificamente, as leis e regulações ambientais vigentes.

Considerando as áreas protegidas pela lei do NCF, em termos de ilustração, no caso das APPs, o total estimado no Brasil seria de 135 milhões ha, dos quais apenas 80 milhões ha detêm cobertura vegetal nativa, sendo que os 55 milhões ha restantes deveriam ser reestruturados pela interrupção do uso atual e regeneração da vegetação (passiva, induzida ou por meio de plantio). Já no caso das RL (lembrando que estas podem ser exigidas, dependendo da região e bioma, em porcentagens de 20,35, 50 ou $80 \%$ ), a área total que supostamente deveria ser de RL no Brasil é de 267 milhões ha sendo que, numa estimativa extremamente otimista, existem 213 milhões ha de vegetação natural fora de UCs e APPs que poderiam ser averbados como RL. Estes 48 milhões ha faltantes deveriam ser restaurados e o uso agrícola existente interrompido, reduzindo assim a produção (SPAROVEK, 2012).

Dentro do bioma Cerrado, a estimativa mais precisa sobre a quantidade de área que deveria estar conservada na forma de RL integral é de 45,7 milhões ha (GUIDOTTI et al., 2017) - aliás, antes da promulgação do NCF, esta área era de 51,9 milhões ha, mas foi reduzida devido à maior permissividade na caracterização das RLs, que incorporaram as áreas de APPs, como observado no capítulo 3 deste trabalho.

Ocorre que, além de tudo, existe um déficit de RL para todos os biomas (estimado em $7 \%$ na média nacional, mas com grande variação regional e por bioma). O Cerrado concentra a maior quantidade nominal de déficit de RL por bioma, somando 4,2 milhões ha (9\% do déficit total de biomas) de vegetação nativa que necessita ser recuperada (GUIDOTTI et al., 2017).

Em termos de vegetação nativa desprotegida, ou seja, excedente às exigências de APP e RL, em áreas rurais privadas, nota-se que esta é cinco vezes maior que o déficit em RLs e APPs. No caso específico do Cerrado, por exemplo, a vegetação nativa desprotegida excede em 7 vezes o déficit em RLs e APPs, perfazendo um total de área de 44 milhões ha - enquanto o déficit de RL é de 4,2 milhões ha e o déficit de APPs é de 1,9 milhões ha (Tabela 16). A tabela a seguir apresenta áreas em valores absolutos (Mha) e valores relativos (\%) às exigências de APPs e RLs (isto é, após o abatimento dos mecanismos de anistia) (GUIDOTTI et al., 2017, p. $5)$. 
Tabela 16 - Déficits de APPs e RLs e o total da vegetação nativa desprotegida por bioma em relação à Lei $\mathrm{n}^{\circ} 12.651$

\begin{tabular}{c|c|c|c|c|c|c}
\hline \multirow{2}{*}{ Bioma } & \multicolumn{2}{|c|}{ Déficit de APP } & \multicolumn{2}{c|}{ Déficit RL } & $\begin{array}{c}\text { Déficit } \\
\text { Total }\end{array}$ & $\begin{array}{c}\text { Vegetação } \\
\text { nativa } \\
\text { desprotegida }\end{array}$ \\
\hline & $\mathrm{Mha}^{1}$ & $\%$ & $\mathrm{Mha}^{1}$ & $\%$ & $\mathrm{Mha}^{1}$ & $\mathrm{Mha}^{1}$ \\
\hline Amazônia & 1.1 & 6 & 3.6 & 4 & 4.7 & 12 \\
\hline Caatinga & 0.8 & 22 & 0.2 & 2 & 1.0 & 35 \\
\hline Cerrado & 1.9 & 24 & 4.2 & 9 & 6.1 & 44 \\
\hline Mata Atlântica & 4.1 & 56 & 2.7 & 22 & 6.8 & $0^{2}$ \\
\hline Pampa & 0.3 & 46 & 0.5 & 18 & 0.8 & 4 \\
\hline Pantanal & 0.0 & 6 & 0.0 & 1 & 0.1 & 8 \\
\hline Brasil & 8.1 & 22 & 11.3 & 7 & 19.4 & 103 \\
\hline
\end{tabular}

Fonte: Guidotti et al. (2017, p. 5).

Notas: ${ }^{1}$ Mha corresponde a 1 milhão de hectares.

${ }^{2}$ A Lei da Mata Atlântica ( $\mathrm{n}^{\circ}$ 11.428) protege o bioma de novos desmatamentos, mas há 24 milhões ha de vegetação nativa excedentes no bioma que poderiam ser utilizados na compensação de RL.

Uma das soluções para esse passivo de RL é a restauração e outra é a compensação, seja em áreas privadas localizadas dentro de UCs, seja mediante áreas nativas em propriedades além da RL exigida. Nota-se que a opção de compensação não está disponível para APPs dadas suas localizações geográficas específicas e necessidades essenciais para manutenção dos serviços ecossistêmicos básicos (como matas ciliares).

A preservação da natureza por meio dos mecanismos do Código Florestal e das UCs é complexa e bioma-específica, sendo que a análise aqui se voltará apenas para o Cerrado. Segundo os dados do CNUC para julho de 2017, dos 204 milhões ha de bioma Cerrado no Brasil, existem 124 UCs de proteção integral ocupando um total de área de 6,5 milhões ha (cerca de 3,2\% da área do bioma) e 389 UCs de uso sustentável ocupando um total de área de 17,23 milhões ha (cerca de 5,5\% da área do bioma). O total, somados os dois tipos de UCs, ocupa uma área de 17,72 milhões ha, o que é equivalente a 8,7\% da área do bioma Cerrado. Como existem sobreposições entre estes, o CNUC também traz o dado de área total líquida (isto é, excluindo as sobreposições): 16,96 milhões ha ou 8,3\% da área total do bioma (Tabela 17). 
Tabela 17 - Áreas das UCs de proteção integral e uso sustentável no Cerrado

\begin{tabular}{|c|c|c|c|}
\hline \multirow{2}{*}{ Área total do bioma (Mha) } & \multicolumn{3}{|c|}{ Cerrado } \\
\hline & \multicolumn{3}{|c|}{204,017} \\
\hline \multicolumn{4}{|l|}{ Tipo/Categoria } \\
\hline Proteção integral (PI) & $\mathrm{n}$. & Área (Mha) & $\%$ \\
\hline Estação Ecológica & 28 & 1,144 & 0,6 \\
\hline Monumento Natural & 13 & 0,037 & 0 \\
\hline Parque & 73 & 5,049 & 2,5 \\
\hline Refúgio de Vida Silvestre & 5 & 0,246 & 0,1 \\
\hline Reserva Biológica & 5 & 0,008 & 0 \\
\hline Total PI & 124 & 6,484 & 3,2 \\
\hline Uso sustentável (US) & $\mathrm{n}$. & Área (Mha) & $\%$ \\
\hline Floresta & 11 & 0,056 & 0 \\
\hline Reserva Extrativista & 6 & 0,088 & 0 \\
\hline Reserva de Desenvolvimento Sustentável & 2 & 0,069 & 0 \\
\hline Reserva de Fauna & 0 & 0 & 0 \\
\hline Área de Proteção Ambiental & 69 & 10,911 & 5,3 \\
\hline Área de Relevante Interesse Ecológico & 16 & 0,009 & 0 \\
\hline RPPN & 161 & 0,107 & 0,1 \\
\hline Total US & 265 & 11,239 & 5,5 \\
\hline Total PI e US & 389 & 17,723 & 8,7 \\
\hline Área de UC considerando sobreposições ${ }^{1}$ & & Área (Mha) & $\%$ \\
\hline Proteção Integral (PI) & & 6,035 & 3 \\
\hline Uso Sustentável (US) & & 10,482 & 5,1 \\
\hline Sobreposição PI e US & & 0,443 & 0,2 \\
\hline Total de UC no bioma & & 16,961 & 8,3 \\
\hline
\end{tabular}

Fonte: CNUC/MMA (10 jul. 2017).

Notas: ${ }^{1}$ As áreas de sobreposição consideradas foram obtidas a partir dos arquivos com dados espaciais cadastrados e validados no CNUC.

Obs. 1: Para a UC que não contém informação georreferenciada disponível, é utilizada a área do ato legal para o cálculo de área.

Obs. 2: Os dados do CNUC estão em constante atualização. Ao utilizá-los, sempre citar a data.

Obs. 3: Área do bioma foi obtida do Instituto Brasileiro de Geografia e Estatística (IBGE, 2004), com ajuste considerando o limite dos municípios (IBGE, 2015) como linha de costa.

O Cerrado oferece oportunidade única para compensação de RL por vários motivos. Primeiramente, ponto pacífico, porque o Cerrado é considerado a mais diversificada savana tropical do mundo ${ }^{90}$ e é também considerado um dos maiores hotspots mundiais de

\footnotetext{
${ }^{90}$ São mais de 7.000 espécies de plantas herbáceas, arbustivas, arbóreas e cipós, 199 espécies de mamíferos, mais de 830 espécies de aves, número elevado de peixes, répteis e anfíbios e fauna de invertebrados pouco conhecida (estima-se em torno de 90.000 espécies) (KLINK; MACHADO, 2005, p. 149-150).
} 
biodiversidade, com pelo menos 137 espécies de animais que ocorrem apenas neste bioma ameaçadas de extinção e ao menos 30 espécies de plantas nativas ornamentais também ameaçadas (KLINK; MACHADO, 2005, p. 150).

Um segundo grupo de razões, também de cunho ambiental, é que 45 mil quilômetros quadrados do Cerrado são áreas degradadas e sujeitas a forte erosão (GOEDERT, 1990) e, além disso, o bioma sofre com a incidência de queimadas - usualmente feitas para limpar os terrenos - que, além de liberar dióxido de carbono e contribuir para o efeito estufa, afetam negativamente o estabelecimento de árvores e arbustos (HOFFMAN; MOREIRA, 2002). Calcula-se que 67\% da área queimada no Brasil em 2000 estavam no Cerrado (TANSEY et al., 2004).

O terceiro motivo pelo qual a compensação de RL deve ser utilizada no Cerrado ${ }^{91}$ tem $^{2}$ a ver com a franca expansão da fronteira agrícola sobre este bioma, principalmente em forma de pastagens e monocultura de grãos. Machado et al. (2004, p. 8) analisam a dinâmica da degradação do bioma e consideram crítica a situação, projetando sua total destruição em 2030, caso "as tendências de ocupação continuem causando uma perda anual de 2,2 milhões de hectares de áreas nativas".

A lógica dos produtores que se utilizarão da compensação de RL é econômica. A dinâmica real dos mercados de regularização ambiental será definida pela maior ou menor atratividade de cada um dos instrumentos de compensação de RL (preço, custo de transação, fatores culturais etc.). Segundo Rajão e Soares-Filho (2015), os proprietários e possuidores rurais com déficits de RL podem ser agrupados em três distintos grupos: 1) aqueles que irão se manter irregulares perante o Código Florestal; 2) aqueles que irão se regularizar no curto prazo por meio de recuperação de áreas com baixo custo de oportunidade; 3) aqueles que irão compensar ${ }^{92}$ o seu déficit de RL e manterão suas áreas produtivas. Para tanto, esses autores estimam o déficit de RL total e o déficit de RL para propriedades de baixa rentabilidade e avaliam que a demanda provável para a compensação de RL será a diferença entre estas duas categorias, ou seja, apenas as áreas com alto custo de oportunidade compensarão os seus déficits de RL.

\footnotetext{
91 Nota-se que não há intenção aqui de dizer que a compensação deve ser o único instrumento aplicado para conservação e mitigação de danos ambientais no Cerrado, mas, sim, que deve ser aplicada em conjunto com outros instrumentos de política ambiental.

${ }^{92}$ Neste estudo, Rajão e Soares-Filho (2015) avaliam o potencial e viabilidade econômica do mercado de CRA no Brasil, portanto, as estimativas e considerações referentes ao déficit de RL são feitas para estimar a aquisição de CRAs. Todavia é possível utilizar essas estimativas e considerações referentes ao déficit de RL para outras modalidades de compensação de RL, como a doação.
} 
Esta situação caracteriza o que se encontra nas propriedades privadas do Cerrado brasileiro. A expansão da fronteira agrícola nesta região por meio de culturas agrícolas valorizadas pelo mercado nacional e internacional induz expectativas dos proprietários rurais no sentido de adquirir propriedades no interior das UCs ou utilizar outros mecanismos de compensação de RL fora de suas propriedades, para compensar o déficit de RL e manter suas áreas produtivas.

A possibilidade de flexibilidade no atendimento da exigência da lei possibilita que esses proprietários produzam na totalidade de área de suas propriedades, aferindo renda proveniente do aumento da produção em área que deveria estar destinada para a RL do imóvel. Esta é uma vantagem econômica que o instrumento de compensação de RL por doação de área em UC pode representar aos proprietários rurais ao reduzir significativamente os custos de regularização ambiental de suas propriedades, ao mesmo tempo que possibilita que os custos de oportunidade para a alocação mais eficiente da RL seja realizado em outra região com custo de oportunidade mais baixo, como os das UCs de domínio público.

Além dos argumentos econômicos, a grande quantidade de área de Cerrado com vegetação natural, mas sem nenhum tipo de proteção (ou seja, que podem ser convertidas para o uso agrícola sem violar nenhuma lei), soma pelo menos 27 milhões ha no Cerrado (SPAROVEK et al., 2010, p. 6049). Isso serve para reforçar a viabilidade da compensação de RL entre privados, dado que estas áreas atualmente podem ser colocadas para uso agrícola (consequentemente, desmatando a vegetação natural), e, com a pressão da expansão da fronteira agrícola, existe a possibilidade que haja valorização da floresta em pé a ponto de se tornar uma opção viável utilizar estas áreas para compensação em vez de exploração agrícola.

\subsection{Metodologia detalhada}

\subsubsection{Conflitos fundiários entre Unidades de Conservação de domínio público com terras de outros domínios no Cerrado}

A metodologia utilizada nesta pesquisa teve como ponto de partida a análise territorial da "Malha Fundiária do Brasil" realizada por Freitas, Guidotti e Sparovek (2017). Com o objetivo de avaliar casos específicos de conflito territorial no bioma Cerrado, foi seguida uma metodologia próxima à do trabalho citado, utilizando as UCs que não aceitam propriedades privadas em seu interior (Quadro 5) e, dessa forma, devem passar por processos de regularização fundiária para que a área de domínio seja do órgão gestor da UC. 
Quadro 5 - UCs federais de domínio público que não aceitam propriedades privadas em seu interior

\begin{tabular}{|c|c|c|c|}
\hline $\begin{array}{c}\text { Categorias de UC (proteção integral e } \\
\text { uso sustentável) }\end{array}$ & Domínio & Posse & $\begin{array}{c}\text { Áreas } \\
\text { particulares serão } \\
\text { desapropriadas }\end{array}$ \\
\hline Estação ecológica & Público & Público & Sim \\
\hline Floresta nacional & Público & Público & Sim \\
\hline Parque nacional & Público & Público & Sim \\
\hline Reserva biológica & Público & Público & Sim \\
\hline Reserva da fauna & Público & Público & Sim \\
\hline Reserva extrativista & Público & $\begin{array}{c}\text { Uso concedido às } \\
\text { populações extrativistas } \\
\text { tradicionais }\end{array}$ & Sim \\
\hline
\end{tabular}

Fonte: MMA (2015).

Como em muitas das UCs não existe nem mesmo um diagnóstico fundiário, o que decorre da fragilidade da governança de terras do Brasil, as UCs de domínio público ainda não estão consolidadas territorialmente.

No presente trabalho, foram utilizados, como alternativa, as tecnologias de geoprocessamento e os dados públicos existentes para identificar possíveis áreas de conflito entre os dados autodeclarados no CAR, as áreas de domínio público e privado registradas no Sigef e os limites oficiais das UCs do bioma Cerrado. Dessa forma, foi possível realizar uma estimativa da oferta existente de áreas para o mercado de compensação de RL por doação de área de UC de domínio público ${ }^{93}$.

Para identificação das UCs que possuem em seu interior áreas privadas, terras indígenas e outras terras públicas, gerando algum conflito fundiário e litígios, utilizou-se as camadas de dados individuais no formato shapefile (Quadro 6) dos limites de UCs, do bioma Cerrado, das terras indígenas, dos assentamentos rurais e os dados de imóveis rurais disponíveis no CAR e

\footnotetext{
${ }^{93}$ Existem informações de áreas ofertadas para o mercado de compensação de RL que são divulgadas pelo ICMBio e por empresas privadas, entre estas, a Bolsa Verde do Rio de Janeiro (BVRio), Geoflorestas, Preserva Legal, Biofílica. Essas empresas oferecem serviços diversos, entre estes, os relacionados à regularização fundiária dessas áreas para sua posterior revenda. Porém estas áreas podem ter algum tipo de irregularidade e/ou conflito fundiário. Dessa forma, não foram utilizadas essas informações na metodologia deste trabalho. O ICMBio também criou uma plataforma virtual em seu sítio da internet para disponibilizar a oferta de áreas particulares inseridas nos limites das UCs para serem compradas por detentores de imóveis rurais que estão com déficit de RL em seus imóveis. Essa plataforma aporta informações sobre os imóveis localizados no interior de UCs, para os quais foram emitidas certidões de habilitação para compensação de RL e tiveram sua divulgação devidamente autorizada (SARETTA, 2017). As certidões de habilitação são documentos que atestam, após análise técnica da dominialidade e localização do imóvel sobreposto à UC, que a área a ser doada ao poder público é legítima para a transação. A oferta das áreas disponibilizadas por essa plataforma do ICMBio até 8 de agosto de 2017 era somente de 161.450,95 ha, de acordo com Saretta (2017, p. 91).
} 
no Sigef. As camadas de dados foram processadas individualmente e depois sobrepostas no ambiente de SIG.

Quadro 6 - Categorias e fontes dos dados utilizados

\begin{tabular}{|l|l|}
\hline \multicolumn{1}{|c|}{ CATEGORIA } & \multicolumn{1}{|c|}{ FONTE } \\
\hline Limites de biomas (Cerrado) & IBGE \\
Terras indígenas & Funai \\
Unidades de conservação (UCs) & MMA \\
\hline Imóveis públicos certificados Sigef & Incra \\
Imóveis privados certificados Sigef & Incra \\
\hline Assentamentos rurais & Incra \\
\hline Terras quilombolas & Incra \\
\hline Cadastro Ambiental Rural (CAR) & Incra \\
\hline
\end{tabular}

Fonte: Elaboração própria.

\subsubsection{Unidades de Conservação no bioma Cerrado}

Para definição da área focal deste estudo, utilizamos os dados das camadas shapefile de biomas do IBGE (Figura 6) e os limites das UCs (Figura 7) disponibilizados pelo MMA. Foram selecionadas somente as categorias de UC de domínio público, que são aquelas que não aceitam propriedades privadas em seu interior para avaliação de ocorrências de sobreposições com outros domínios públicos e privados (camada $U C_{-} C E R R A D O$ ). A lista das 63 UCs enquadradas nessa seleção pode ser observada no Quadro 7. 
Figura 6 - Biomas brasileiros

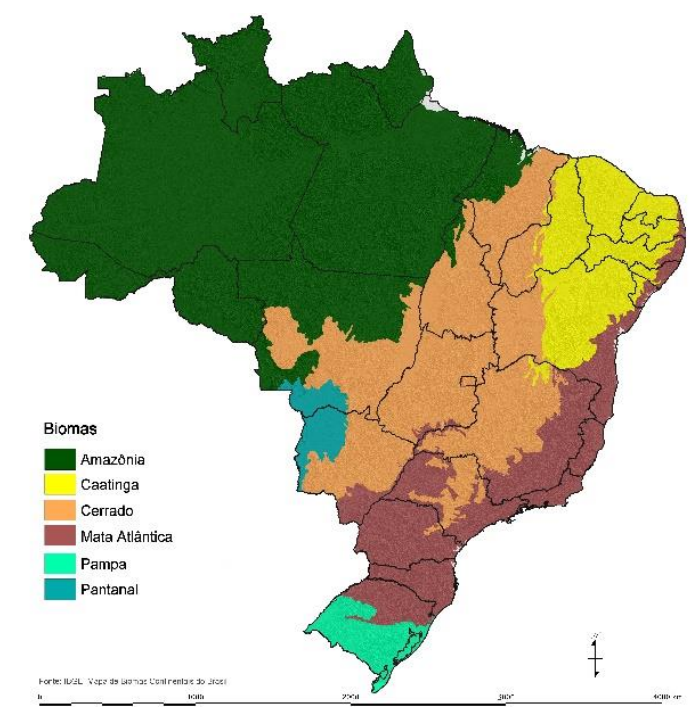

Fonte: IBGE (2004).

Figura 7 - UCs no bioma Cerrado

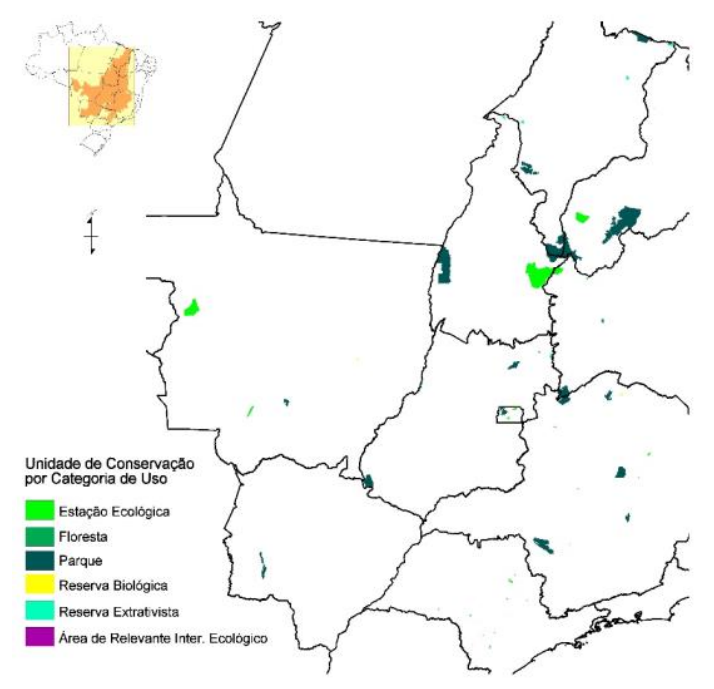

Fonte: IBGE (2004). 
Quadro 7 - Lista de UCs do bioma Cerrado

\begin{tabular}{|c|c|c|c|}
\hline \multicolumn{4}{|c|}{ Unidades de Conservação no Bioma Cerrado } \\
\hline Nome da UC & Grupo* & Categoria & Esfera \\
\hline PARQUE NACIONAL DA CHAPADA DOS GUIMARÃES & PI & Parque & federal \\
\hline RESERVA EXTRATIVISTA LAGO DO CEDRO & us & Reserva Extrativista & federal \\
\hline PARQUE NACIONAL DA SERRA DA BODOQUENA & PI & Parque & federal \\
\hline PARQUE NACIONAL DAS EMAS & PI & Parque & federal \\
\hline ESTAÇÃO ECOLÓGICA DA SERRA DAS ARARAS & PI & Estação Ecológica & federal \\
\hline RESERVA BIOLÓGICA CULUENE & PI & Reserva Biológica & estadual \\
\hline ESTAÇÃO ECOLÓGICA ITABERÁ & PI & Estação Ecológica & estadual \\
\hline ESTAÇÃO ECOLÓGICA DE AVARÉ & PI & Estação Ecológica & estadual \\
\hline ESTAÇÃO ECOLÓGICA DE CORUMBÁ & PI & Estação Ecológica & estadual \\
\hline ESTAÇÃO ECOLÓGICA JATAÍ & PI & Estação Ecológica & estadual \\
\hline PARQUE NACIONAL GRANDE SERTÃO VEREDAS & PI & Parque & federal \\
\hline ESTAÇÃO ECOLÓGICA DE SANTA BÁRBARA & PI & Estação Ecológica & estadual \\
\hline ESTAÇÃO ECOLÓGICA IBICATU & PI & Estação Ecológica & estadual \\
\hline ESTAÇÃO ECOLÓGICA DE MOGI-GUAÇU & PI & Estação Ecológica & estadual \\
\hline ESTAÇÃO ECOLÓGICA DO JARDIM BOTÂNICO & PI & Estação Ecológica & estadual \\
\hline ESTAÇÃO ECOLÓGICA DE SAGARANA & PI & Estação Ecológica & estadual \\
\hline RESERVA BIOLÓGICA DO GAMA & PI & Reserva Biológica & estadual \\
\hline RESERVA EXTRATIVISTA DO RECANTO DAS ARARAS DE TERRA RONCA & us & Reserva Extrativista & federal \\
\hline ESTAÇÃO ECOLÓGICA DO BARREIRO RICO & PI & Estação Ecológica & estadual \\
\hline RESERVA BIOLÓGICA DO GUARÁ & PI & Reserva Biológica & estadual \\
\hline PARQUE NACIONAL DE BRASÍLIA & PI & Parque & federal \\
\hline PARQUE NACIONAL CAVERNAS DO PERUAÇU & PI & Parque & federal \\
\hline ESTAÇÃO ECOLÓGICA DE SANTA MARIA & PI & Estação Ecológica & estadual \\
\hline ESTAÇÃO ECOLÓGICA MATA DOS AUSENTES & PI & Estação Ecológica & estadual \\
\hline RESERVA BIOLÓGICA JAÍBA & PI & Reserva Biológica & estadual \\
\hline RESERVA BIOLÓGICA DO CERRADÃO & us & Área de Rel. Inter. Ecológico & estadual \\
\hline PARQUE NACIONAL DA SERRA DA CIPÓ & PI & Parque & federal \\
\hline ESTAÇÃO ECOLÓGICA DE BAURU & PI & Estação Ecológica & estadual \\
\hline ESTAÇÃO ECOLÓGICA DE ANGATUBA & PI & Estação Ecológica & estadual \\
\hline FLORESTA NACIONAL DA MATA GRANDE & us & Floresta & federal \\
\hline FLORESTA NACIONAL DE PARAOPEBA & us & Floresta & federal \\
\hline ESTAÇÃO ECOLÓGICA DE PIRAPITINGA & PI & Estação Ecológica & federal \\
\hline ESTAÇÃO ECOLÓGICA DE ÁGUAS EMENDADAS & PI & Estação Ecológica & estadual \\
\hline ESTAÇÃO ECOLÓGICA DE ITAPEVA & PI & Estação Ecológica & estadual \\
\hline FLORESTA NACIONAL DE BRASÍLIA & us & Floresta & federal \\
\hline RESERVA BIOLÓGICA DA CONTAGEM & PI & Reserva Biológica & federal \\
\hline ESTAÇÃO ECOLÓGICA MATA DO JACARÉ & PI & Estação Ecológica & estadual \\
\hline RESERVA BIOLÓGICA DO RIO DESCOBERTO & PI & Reserva Biolagica & estadual \\
\hline ESTAÇূ̃O ECOLÓGICA DE PARANAPANEMA & PI & Estação Ecológica & estadual \\
\hline PARQUE NACIONAL DAS SEMPRE VIVAS & PI & Parque & federal \\
\hline ESTAÇÃO ECOLÓGICA DE ASSIS & PI & Estação Ecológica & estadual \\
\hline FLORESTA NACIONAL DE CAPÃO BONITO & us & Floresta & federal \\
\hline ESTAÇÃO ECOLÓGICA DE ITIRAPINA & PI & Estação Ecológica & estadual \\
\hline PARQUE NACIONAL DA SERRA DA CANASTRA & PI & Parque & federal \\
\hline PARQUE NACIONAL DA CHAPADA DOS VEADEIROS & PI & Parque & federal \\
\hline ESTAÇÃO ECOLÓGICA DE RIBEIRÃO PRETO & PI & Estação Ecológica & estadual \\
\hline ESTAÇÃO ECOLÓGICA DE ACAUÃ & PI & Estação Ecológica & estadual \\
\hline FLORESTA NACIONAL DE SILVÂNIA & us & Floresta & federal \\
\hline ESTAÇÃO ECOLÓGICA DE IQUÊ & PI & Estação Ecológica & federal \\
\hline PARQUE NACIONAL DO ARAGUAIA & PI & Parque & federal \\
\hline ESTAÇÃO ECOLÓGICA DO RIO PRETO & PI & Estação Ecológica & estadual \\
\hline ESTAÇÃO ECOLÓGICA DE URUÇUÍ-UNA & PI & Estação Ecológica & federal \\
\hline FLORESTA NACIONAL DE CRISTÓPOLIS & us & Floresta & federal \\
\hline PARQUE NACIONAL SERRA DAS CONFUSIES & PI & Parque & federal \\
\hline PARQUE NACIONAL DA CHAPADA DAS MESAS & PI & Parque & federal \\
\hline RESERVA EXTRATIVISTA MATA GRANDE & us & Reserva Extrativista & federal \\
\hline RESERVA EXTRATIVISTA EXTREMO NORTE DO TOCANTINS & us & Reserva Extrativista & federal \\
\hline FLORESTA NACIONAL DE PALMARES & us & Floresta & federal \\
\hline RESERVA EXTRATIVISTA CHAPADA LIMPA & us & Reserva Extrativista & federal \\
\hline RESERVA EXTRATIVISTA MARINHA DO DELTA DO PARNAIBA & us & Reserva Extrativista & federal \\
\hline PARQUE NACIONAL DOS LENÇÓIS MARANHENSES & PI & Parque & federal \\
\hline ESTACAO ECOLÓGICA SERRA GERAL DO TOCANTINS & PI & Estação Ecológica & federal \\
\hline PARQUE NACIONAL DAS NASCENTES DO RIO PARNAIBA & PI & Parque & federal \\
\hline
\end{tabular}

Fonte: CNUC/MMA (10 jul. 2017).

A área das UCs de domínio público do Cerrado calculada nesta metodologia que utilizou o shapefile do bioma Cerrado e dos limites das UCs disponibilizados pelo MMA apresenta um valor menor do que a informação desta mesma área das UCs analisadas informada pelo MMA, conforme consta na Tabela 6 do capítulo 5, reproduzida na Tabela 17 somente para a descrição do Cerrado. 
A Tabela 18, com as áreas calculadas pela metodologia utilizada e informadas pelo MMA, mostra esta diferença de áreas das UCs de domínio público do Cerrado.

Tabela 18 - Diferença de áreas a partir dos dados do CNUC e da área calculada na metodologia de georreferenciamento das UCs de domínio público do Cerrado em milhões de hectares (Mha)

\begin{tabular}{l|r|r|r}
\hline $\begin{array}{l}\text { Unidade de Conservação } \\
\text { de domínio Público }\end{array}$ & $\begin{array}{c}\text { Área calculada da } \\
\text { UC (Mha) }\end{array}$ & CNUC (Mha) & Diferença (Mha) \\
\hline Estação Ecológica & 1,13719064 & 1,144 & 0,00680936 \\
\hline Floresta Nacional & 0,02928123 & 0,056 & 0,02671877 \\
\hline Parque Nacional & 3,594852372 & 5,049 & 1,454147628 \\
\hline Reserva Biológica & 0,01454639 & 0,008 & 0,00654639 \\
\hline Reserva Extrativista & 0,08902469 & 0,088 & 0,00102469 \\
\hline TOTAL & $\mathbf{4 , 8 6 4 8 9 5 3 2 2}$ & $\mathbf{6 , 3 4 5}$ & $\mathbf{1 , 4 8 0 1 0 4 6 7 8}$ \\
\hline
\end{tabular}

Fonte: Elaboração própria a partir de CNUC\MMA (julho de 2017).

Os dados do CNUC\MMA somam uma área total de 6,345 Mha, enquanto os dados da área calculada a partir do shapefile do bioma Cerrado e dos limites das UCs disponibilizadas pelo MMA somam 4,86 Mha. A diferença entre estas fontes de dados está na ordem de 1,48 Mha.

A única UC de domínio público com uma área maior calculada na metodologia de georreferenciamento é a reserva extrativista (Resex), sendo que as demais apresentam áreas menores.

Existem diversas hipóteses para essa diferença de áreas, pode ser, por exemplo, por consequência de dados desatualizados do MMA. Dessa forma, nas informações das UCs que ainda não possuem áreas georreferenciadas disponíveis, o MMA utilizou a área do ato legal para o cálculo da área. Também pode existir UCs de domínio público do bioma Cerrado que não estão georreferenciadas, como é o caso dos parques estaduais, portanto estas não aparecem no shapefile do bioma Cerrado e nos limites das UCs disponibilizadas pelo MMA.

De qualquer forma, foi utilizada a área calculada das UCs de domínio público do bioma Cerrado realizada e disponibilizada pelo MMA inserida na metodologia deste trabalho de acordo com o realizado por Freitas, Guidotti e Sparovek (2017).

\subsubsection{Cadastro Ambiental Rural - CAR}

Dispositivos e regulamentações que visam a facilitar a delimitação das propriedades rurais, entre as quais, o Sicar, também facilitaram o processo de cadastramento dos imóveis. 
Porém verifica-se, atualmente, com mais frequência incorreções nos limites das propriedades gerando sobreposições entre terras privadas e entre privadas e públicas. Para reduzir essas incorreções, as camadas de dados individualizadas do CAR de cada estado (UF) foram analisadas e os dados foram agregados em uma única camada que representa a área total declarada pelos imóveis rurais que foi chamada de camada MERGE_CAR.

A consulta ao Sicar das áreas rurais autodeclaradas no CAR foi realizada até a data de março de 2018. O prazo para o cadastramento das propriedades e posses rurais, que seria finalizado em 31 de dezembro de 2017, foi prorrogado por mais cinco meses pelo Decreto $\mathrm{n}^{\circ}$ 9.257 da Presidência da República. O prazo para proprietários e posseiros rurais fazerem o CAR foi estendido para 31 de maio de $2018^{94}$. Dessa forma, algumas áreas ainda podem vir a ser autodeclaradas no CAR. Estas áreas não estão contempladas nas análises deste trabalho.

As áreas cadastradas no CAR podem ser tanto posses como propriedades privadas, sendo que este cadastro não especifica, entre as áreas autodeclaradas, as diferenças de dominialidade destas áreas. Dessa forma, as áreas cadastradas no CAR são informações de áreas que nos mostram apenas a quantidade potencial de terras para serem ofertadas no mercado de compensação de RL por doação de áreas à instituição gestora e responsável pela UC.

Como não é possível desmembrar das áreas cadastradas no CAR as posses das propriedades privadas - e como neste mercado não se pode negociar áreas de posse, somente aquelas que são propriedades -, as áreas autodeclaradas no CAR informam somente a oferta potencial de áreas para ingressar no mercado de compensação de RL analisado.

Vale ressaltar que, assim como podem existir áreas cadastradas no CAR que são propriedades privadas e não possuem georreferenciamento de suas áreas certificadas pelo Incra no Sigef, também podem existir áreas com algum tipo de irregularidade cadastradas nesse sistema, que possuem algum tipo de fraude. Estas são limitações das análises decorrentes da fragilidade da governança de terras do Brasil, em que o sistema de administração de terras, ou seja, os cadastros e suas instituições gestoras não se comunicam.

Estas limitações seriam menores, como analisado no capítulo 4, se o CAR tivesse alguma comunicação com a base fundiária das propriedades e posses cadastradas no SNCR e no Sigef, visto que mais de $60 \%$ das áreas do território brasileiro estão certificadas no Sigef.

\footnotetext{
94 Os imóveis rurais que não fizerem o CAR dentro do prazo deixarão de ter acesso aos benefícios previstos no Código Florestal (Lei n ${ }^{\circ}$ 12.651/2012), como a regra da escadinha e a adesão ao PRA, e, a partir de junho de 2018, não terão acesso a novos financiamentos bancários.
} 


\subsubsection{Sistema de Gestão Fundiária - Sigef}

As camadas de dados dos imóveis rurais para cada estado foram unidas em duas camadas distintas, chamadas MERGE_SIGEFPUB e MERGE_SIGEFPRI.

Os imóveis rurais cadastrados e cerificados no Sigef, em teoria, apresentam menor inconsistência quanto às sobreposições dos registros, devido ao sistema de verificação do próprio Sigef, quando comparados ao Sicar. As áreas particulares cadastradas (no interior das UCs de domínio público) no Sigef e certificadas pelo Incra, até a data de março de 2018, quando se realizou a pesquisa destes dados, são aquelas que realmente estão aptas para serem ofertadas no mercado de compensação de RL por doação de área de UC, por possuírem matrícula registrada no Cartório de Registro de Imóveis.

Com observado no capítulo 4 deste trabalho, no item sobre as fragilidades do Sigef, a Lei $n^{\circ} 10.267$ de 2001 especifica que somente os imóveis rurais que precisaram passar por um desmembramento, parcelamento ou remembramento são obrigados a realizar seu georreferenciamento e cadastrá-lo no Sigef para obter a certificação do Incra. Dessa forma, existem áreas de propriedades privadas que não estão cadastradas nesse sistema por não terem sido objetos de desmembramento etc.

As propriedades rurais com menos de 4 módulos fiscais também estão isentas da certificação do georreferenciamento de suas áreas caso precisem ser vendidas, remembradas etc. O governo federal está na responsabilidade de realizar o georreferenciamento desses imóveis rurais, mas ainda não se sabe quando e como isso irá ocorrer.

A obrigatoriedade da realização do georreferenciamento dos imóveis rurais nos casos mencionados anteriormente para a atualização de seus registros está válida até o ano de 2025.

O cadastro georreferenciado, preconizado tanto no SNCR como no CNIR, não tem prazo definido para estar completo e atualizado, dependendo de alguma ação a mais do governo federal, para além da necessidade imposta pela Lei n 10.276 de 2001, alínea A do item 3, inciso II do parágrafo $1^{\circ}$, que obriga o georreferenciamento dos imóveis rurais para os casos de desmembramento etc., já mencionados.

É importante destacar que podem existir propriedades privadas que não estão certificadas no Sigef, assim como podem existir propriedades privadas cadastradas no CAR que não estão certificadas no Sigef.

Mesmo com essas fragilidades existentes no sistema de cadastros do Brasil, é possível aferir (até março de 2018) quanto de área particular em hectares está certificado no Sigef e ter 
uma aproximação de uma oferta real de áreas para o mercado de compensação de RL por doação de área de UC de domínio público.

\subsubsection{Terras indígenas, quilombolas e assentamentos rurais}

Com o objetivo de verificar a sobreposição das terras indígenas, quilombos e assentamentos rurais com as UCs, foram criadas as camadas de dados TERRA_INDIGENA e ASSENTAM_RURAL. Como não foi verificada a ocorrência de conflitos fundiários com áreas quilombolas, não foi necessária a inclusão dessa camada.

\subsubsection{Dados do Cadastro Nacional de Unidades de Conservação (CNUC)}

Foram utilizadas também as informações dos cadastrados analisados, assim como as informações do CNUC relacionadas à situação fundiária de cada UC de domínio público do Cerrado. Estas informações fundiárias são aquelas que indicam se as UCs de domínio público estão totalmente, parcialmente ou não regularizadas e se estas possuem ou não ocupações de pessoas.

A consulta ao banco de dados do CNUC foi realizada em fevereiro de 2017. Vale acrescentar que o CNUC não possui informações fundiárias e de ocupação para todas as UCs do Cerrado, ficando um montante considerável de UCs sem apresentar estas informações. As informações fundiárias de cada UC do Cerrado, quando existentes, estão sinalizadas nas tabelas referentes a cada categoria de UCs de domínio público analisada nos itens subsequentes.

\subsubsection{Processamento dos dados das camadas analisadas}

Assim como no trabalho de Freitas, Guidotti e Sparovek (2017), houve a necessidade da criação de regras de decisão para verificar as sobreposições existentes intra e entrecamadas de dados. Para redução das inconsistências intracamada (sobreposições dos limites entre os imóveis rurais) e definição de um método único de contabilizar a área de cada camada dentro das UCs, os dados das camadas poligonais (vetores) MERGE_CAR, MERGE_SIGEFPUB, MERGE_SIGEFPRI, TERRA_INDIGENA e ASSENTAM_RURAL foram convertidos em camadas matriciais (rasters) individuais utilizando-se uma máscara com a mesma informação geográfica e tamanho de pixel (50x50 metros). O resultado desse procedimento, descrito em 
Freitas, Guidotti e Sparovek (2017) para geração de uma malha fundiária, priorizando-se as UCs na sobreposição, pode ser observado na Figura 8.

Figura 8 - Estrutura (domínio) fundiária por tipo de proprietário, com base na metodologia de Freitas, Guidotti e Sparovek (2017), para o bioma Cerrado

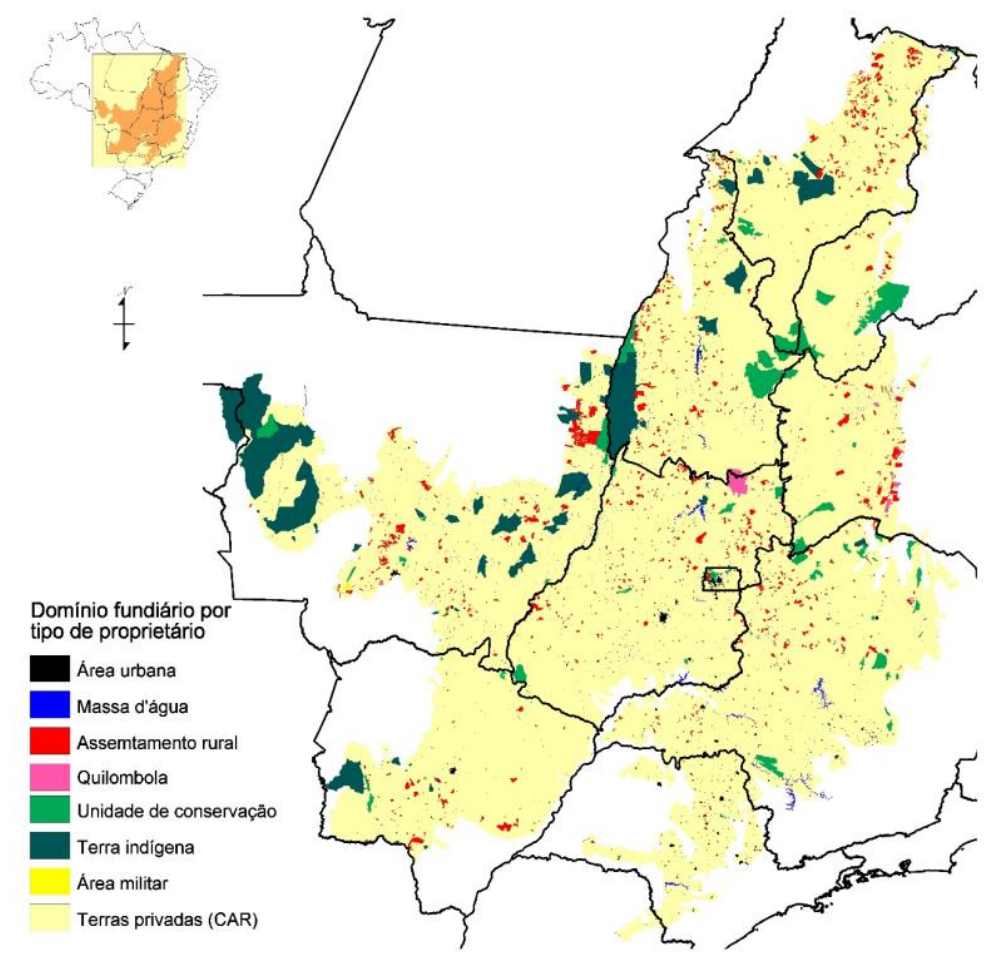

Fonte: Freitas, Guidotti e Sparovek (2017).

Para o processamento entrecamadas, as camadas matriciais foram extraídas utilizandose a camada UC_CERRADO. Foram contabilizadas em valor de área cada uma das camadas matriciais para cada uma das UCs, e os valores foram tabelados. As sobreposições das camadas entre si também foram processadas e seus valores adicionados à tabela, de modo que as áreas em conflito entre duas ou mais camadas fossem verificadas e posteriormente discutidas. Por meio desse método, aferiu-se a quantidade de áreas em hectares (ha) cadastradas no CAR, certificadas como públicas e particulares no Sigef, as terras indígenas e os assentamentos.

Para cada categoria dessas terras, mencionadas anteriormente, foram calculadas suas áreas e suas sobreposições entre si. O Quadro 8 mostra as siglas que são utilizadas nas tabelas, discutidas nos próximos itens, e as sobreposições de áreas calculadas entre si. 
Quadro 8 - Siglas e suas definições das categorias de terras e suas sobreposições de áreas

\begin{tabular}{|l|l|}
\hline SIGLAS & Definição \\
\hline Área da UC (hectares) & Área calculada do vetor de perímetro da UC \\
\hline$\%$ Área da UC & Percentual da área da UC em relação na área total das áreas das UCs do cerado \\
\hline UF & Unidade da Federação/Estado \\
\hline CAR (hectares) & Área calculada de limites do CAR dentro da UC (hectares) \\
\hline CAR (\% na UC) & \% da Área do CAR dentro da UC em relação à área total da UC \\
\hline SIGEF Particular (hectares) & Área calculada de limites de propriedades particulares do SIGEF certificado dentro da UC (hectares) \\
\hline SIGEF Público (hectares) & Área calculada de limites de propriedades públicas do SIGEF certificado dentro da UC (hectares) \\
\hline Terra Indígena (hectares) & Área calculada de Terras indígenas dentro da UC (hectares) \\
\hline Assentamento (hectares) & Área calculada de Assentamentos rurais dentro da UC (hectares) \\
\hline CAR/SIGEF (hectares) & Sobreposição CAR/(Sigef particular + Sigef Público) (\% da UC) \\
\hline CAR/Assentamento (hectares) & Sobreposição CAR/Assentamentos (hectares) \\
\hline CAR/Terra Indígena (hectares) & Sobreposição CAR/Terras indígenas (hectares) \\
\hline SIGEF Público/Particular (hectares) & Sobreposição Sigef particular / Sigef Público (hectares) \\
\hline SIGEF Total (hectares) & Área total de SiGEF (Sigef particular OU Sigef Público) dentro da UC (hectares) \\
\hline SIGEF/Assentamento (hectares) & Sobreposição SIGEF/Assentamentos (hectares) \\
\hline SIGEF/Terra Indígena (hectares) & Sobreposição SIGEF/Terras indígenas (hectares) \\
\hline
\end{tabular}

Fonte: Elaboração própria.

O objetivo deste trabalho é analisar a consolidação territorial das UCs de domínio público do Cerrado e a contribuição da oferta de áreas para o mercado de terras de compensação de RL por doação de área de UC de domínio público na regularização fundiária dessas UCs no bioma Cerrado. Nesse sentido, há um interesse em evidenciar quais UCs de domínio público possuem áreas privadas certificadas no Sigef, que são aquelas aptas para serem ofertadas neste mercado de terras de compensação de RL, possibilitando ter suas áreas regularizadas, ou seja, elas deixarão de estar no domínio de particulares, passando para o domínio público, do órgão estatal responsável por sua gestão.

A partir das informações coletadas por meio das tecnologias de geoprocessamento e dos dados públicos para identificar possíveis áreas de conflito entre os dados autodeclarados no CAR, as áreas de domínio público e privado registradas no Sigef e os limites oficiais das UCs do bioma Cerrado, foi calculada a quantidade de oferta atual de áreas de propriedade particular para o mercado de compensação de RL por doação de áreas de UC de domínio público.

As áreas particulares certificadas no Sigef são as que mais se aproximam da propriedade privada, pois possuem matrícula e estão georreferenciadas (sem sobreposições de áreas) e certificadas pelo Incra. Em outras palavras, este indicador é o que mais se aproxima das áreas que são propriedade privada, apesar das inconsistências apontadas no capítulo 4 desta tese, principalmente a de que somente $6 \%$ da área certificada no Sigef no Brasil, no ano de 2015, tinha sido averbada na matrícula do imóvel nos Cartórios de Registro de Imóveis (REYDON; BUENO; SIQUEIRA, 2017). 
$\mathrm{Na}$ análise dos dados das UCs de domínio público do Cerrado, o indicador de área particular certificada no Sigef, após descontadas do cálculo destas áreas as sobreposições existentes com áreas certificadas no Sigef como públicas, áreas indígenas e áreas de assentamentos, obteve-se a oferta de área particular atual que poderá ingressar no mercado de compensação de RL por doação de área de UC de domínio público.

A análise das áreas potenciais para serem ofertadas no mercado de terras de compensação de RL por doação de área de UC de domínio público tem como indicador a área cadastrada no CAR, descontadas as sobreposições de áreas certificadas como pública e particular no Sigef e as demais áreas existentes no território das UCs, que são as terras indígenas e os assentamentos.

Conforme mencionado nos itens anteriores, no CAR estão cadastradas as posses e propriedades privadas. Porém este cadastro não tem comunicação com o cadastro fundiário do Incra. Ambos não estão interligados, dessa forma, não se pode constatar o que é posse do que é propriedade, nem mesmo no CAR essas áreas estão discriminadas. Mesmo com essa ressalva, este indicador é importante para estimar o montante de área declarada e cadastrada nos limites das áreas das UCs como área particular e que, potencialmente, após resolvidos os conflitos burocráticos e fundiários, poderão ingressar como área a ser ofertada no mercado de terras de compensação de RL por doação de área de UC de domínio público.

Um outro indicador importante para se considerar na análise sobre a consolidação territorial das UCs de domínio público do Cerrado é a quantidade de terras inseridas no território destas UCs que estão sem cadastros. Este indicador foi calculado por meio da fórmula: área da UC subtraída da soma da área cadastrada no CAR sem sobreposição de áreas no Sigef particular e público, de terras indígenas e de assentamento (ou seja, é o mesmo cálculo para se encontrar o indicador de oferta potencial de terras para o mercado de compensação de RL analisado), somado à área do Sigef total (público mais o particular) sem sobreposição de áreas somado à área de assentamento e de terra indígena.

O indicador de terras sem cadastros nas UCs de domínio público pode ser traduzido na fórmula: área da UC sem cadastro = área da UC - (CAR sem sobreposição de áreas + Sigef público e particular sem sobreposição de áreas + terras indígenas + áreas de assentamentos).

Para somar a essas análises, foi pesquisada a situação fundiária das UCs de domínio público do Cerrado de acordo com as informações existentes, até agosto de 2017, no CNUC, ou seja, se elas estão totalmente regularizadas, parcialmente regularizadas e não regularizadas. Também foram consideradas as informações do CNUC sobre a existência de ocupações ou não nas UCs de domínio público do Cerrado. Estas informações sobre a situação fundiária das UCs 
e a existência ou não de ocupações estão sinalizadas nas tabelas. Também está sinalizado nas tabelas as UCs que possuem plano de manejo ${ }^{95}$.

Vale ressaltar que algumas UCs não possuem informações sobre sua situação fundiária, se a área está ocupada e sobre a existência de plano de manejo. Nesses casos, as UCs aparecem sem a sinalização que corresponde a estas informações nas tabelas.

A análise desses indicadores é importante para as iniciativas de políticas, a serem adotadas pelos órgãos gestores das UCs, com o objetivo de alcançar a consolidação territorial dessas UCs.

Os mapas de cada UC de domínio público do Cerrado, com a porcentagem de áreas por categoria de Sigef público, particular, CAR, terra indígena e assentamento, estão no anexo.

Os principais indicadores (oferta atual, potencial e porcentagem de área sem cadastros na UCs) analisados no contexto da consolidação territorial de cada categoria de UCs de domínio público do Cerrado estão descritos nos itens subsequentes.

\subsection{Resultados}

6.4.1 Ofertas atual e potencial de áreas para ingressarem no mercado de compensação de RL por doação de área de UC de domínio público: uma análise dos parques nacionais (Parnas) do bioma Cerrado e suas áreas sem cadastros

Os Parnas do Cerrado, que somam ao todo 15 parques, possuem uma área total de 3.594.852,37 hectares, cerca de 73,89\% da área de todas as UCs de domínio público do Cerrado.

Da área total dos Parnas do Cerrado, 445.029,21 ha são áreas particulares certificadas no Sigef, o que representa um percentual médio de $12,38 \%$ de sua área total.

Destas áreas, descontadas as sobreposições de áreas certificadas como públicas, terras indígenas e assentamentos, tem-se uma área de 445.865,17 ha, representando 12,13\% das áreas totais dos Parnas do Cerrado. Estas são as áreas que, atualmente (até a data de março de 2018), podem ser ofertadas no mercado de compensação de RL por doação de área de UC de domínio público.

A maioria dos Parnas do Cerrado não possui terras certificadas no Sigef como públicas, nem assentamentos e terras indígenas. Nestes casos, a oferta de área atual para o mercado em análise será o mesmo indicador da área certificada como particular no Sigef. São poucos os

\footnotetext{
${ }^{95}$ As informações sobre plano de manejo de cada UC de domínio público do Cerrado têm como referência o site: $\langle$ http://www.icmbio.gov.br/portal/images/stories/docs-planos-de-manejo>.
} 
Parnas que possuem terras públicas certificadas no Sigef (Parnas Nascentes do Rio Parnaíba, Chapada dos Veadeiros e de Brasília), terras indígenas (Parnas do Araguaia e Cavernas de Peruaçu) e assentamentos (Parnas Grande Sertão Veredas e do Araguaia). A Tabela 19 traz todas as informações destes parques.

As áreas que foram cadastradas no CAR como posses e/ou propriedades privadas somam um total de 1.072.653,56 ha, correspondendo, em média, a um percentual de 29,84\% de sua área total. Estas áreas, descontadas as sobreposições de áreas privadas e públicas certificadas no Sigef, assentamentos e terras indígenas, resultam numa área de 749.565,22 ha, representando 20,85\% da área total dos Parnas do Cerrado. Esta é a oferta potencial de áreas para o mercado de compensação de RL por doação de área de UC de domínio público.

Como o CAR não especifica o que é posse e propriedade, não se pode analisar a situação de posse e domínio desta área. Assim, ela pode ser composta tanto por áreas de propriedades privadas que ainda não realizaram a certificação do georreferenciamento no Sigef como por áreas com conflitos fundiários e/ou burocráticos.

Chama a atenção o percentual de área sem cadastros nos Parnas do Cerrado, que é de $50,84 \%$, correspondendo a uma área de 1.827.532,82 ha que não está cadastrada no CAR, no Sigef e não consta registro de áreas ocupadas por assentamentos e terras indígenas.

As informações do CNUC em relação à situação fundiária dos Parnas atestam que 33\% dessas UCs, ou seja, 5 estão parcialmente regularizadas (Chapada dos Veadeiros, Grande Sertão Veredas, Serra das Confusões, Serra da Canastra e Chapada dos Guimarães), 53,33\% possuem ocupações (Nascentes do Rio Parnaíba, Chapada dos Veadeiros, Grande Sertão Veredas, Chapada das Mesas, Sempre-Vivas, Serra da Canastra, Chapada dos Guimarães e Parque de Brasília) e 66,66\% possuem plano de manejo (Grande Sertão Veredas, Serra das Confusões, Serra da Bodoquena, das Sempre-Vivas, Serra da Canastra, Caverna de Peruaçu, Chapada dos Guimarães, de Brasília, Araguaia e Lençóis Maranhenses).

Os Parnas que possuem uma maior área de oferta atual, em termos percentuais, em relação à área total da UC, que pode ingressar no mercado de compensação de RL por doação de área de UC de domínio público são: Serra da Bodoquena (34,71\%), Chapada dos Veadeiros (30,06\%), Grande Sertão Veredas (26,95\%), Nascentes do Rio Parnaíba (24\%), Chapada das Mesas $(19,93 \%)$ e das Sempre-Vivas $(13,64 \%)$. Os demais Parnas possuem menos do que $6,76 \%$ de área atual certificada como particular no Sigef, sendo que o Parna da Serra do Cipó possui um indicador de 0,05\% de sua área com área atual e o Parna das Emas 0,23\% de sua área para ser ofertada no mercado de compensação de RL por doação de área de UC de domínio público. 
Os Parnas do Cerrado que possuem maior área de oferta potencial (que é a área cadastrada no CAR retiradas as sobreposições com áreas certificadas públicas e particulares no Sigef, assentamentos e terras indígenas) em relação à sua área total são os seguintes: Parna de Brasília (70,40\%), da Serra da Canastra (32,43\%), Serra das Confusões (31,10\%), Grande Sertão Veredas (28,81\%), Chapada das Mesas (28,59\%). Dentre estes Parnas, os três primeiros, que possuem maiores indicadores de oferta potencial de áreas, possuem um baixo percentual em relação à área de oferta atual de áreas para o mercado de terras de compensação de RL por doação de área de UC de domínio público, respectivamente, 0,01\%, 6,76\% e 3,91\%.

$\mathrm{O}$ indicador de sobreposição de área do CAR em relação ao Sigef particular indica as áreas que foram cadastradas no CAR e possuem certificação no Sigef. O Parna de Brasília possui $1,03 \%$ de área do CAR sobreposta com área do Sigef particular, o parque da Serra da Canastra possui 16,19\% de área sobreposta e o Parna da Serra das Confusões possui 4,65\% de suas áreas sobrepostas no CAR e no Sigef particular.

As áreas de oferta potencial, que não possuem sobreposição de áreas, são aquelas que podem ter sido cadastradas no CAR e não certificadas no Sigef ou são áreas de posse mansa e pacífica, que não possuem matrícula, mas poderão se tornar propriedade de acordo com os requisitos do artigo $5^{\circ}$ do Código Civil ou são posses em áreas devolutas. A Tabela 19 mostra estes indicadores. 
Tabela 19 - Oferta atual, potencial e áreas sem cadastro dos Parnas do bioma Cerrado em hectares (dados de março de 2018)

\begin{tabular}{|c|c|c|c|c|c|c|c|c|c|c|c|c|c|c|c|c|c|c|c|c|c|c|c|c|}
\hline $\begin{array}{c}\text { Nome Parques Nacionais } \\
\text { (PARNAs) }\end{array}$ & UF & Área UC (ha) & $\begin{array}{c}(\%) \text { da } \\
\text { UC na } \\
\text { Area } \\
\text { Total } \\
\text { UCs }\end{array}$ & CAR (ha) & $\begin{array}{l}\text { (\%) CAR } \\
\text { na UC }\end{array}$ & $\begin{array}{c}\text { CAR/SIGE } \\
\text { F (hectares) }\end{array}$ & $\begin{array}{c}\text { CAR/As } \\
\text { sentam } \\
\text { ento } \\
\text { (hectare } \\
\text { s) }\end{array}$ & $\begin{array}{c}\text { CAR/Terra } \\
\text { Indigena } \\
\text { (hectares) }\end{array}$ & $\begin{array}{c}\text { Total de } \\
\text { área } \\
\text { sobreposiç } \\
\text { ão CAR }\end{array}$ & $\begin{array}{c}\text { Oferta } \\
\text { Potencial } \\
\text { CAR sem } \\
\text { sobreposiçãa } \\
\text { o (ha) }\end{array}$ & $\begin{array}{l}\text { SIGEF } \\
\text { Particular } \\
\text { (ha) }\end{array}$ & $\begin{array}{l}\text { SIGEF } \\
\text { Público } \\
\text { (ha) }\end{array}$ & $\begin{array}{c}\text { SIGEF } \\
\text { Total }\end{array}$ & $\begin{array}{l}\text { SIGEF } \\
\text { Público/Pa } \\
\text { rticular } \\
\text { (ha) }\end{array}$ & $\begin{array}{c}\text { SIGEF/ } \\
\text { Assenta } \\
\text { mento } \\
\text { (ha) }\end{array}$ & $\begin{array}{l}\text { SIGEF/T } \\
\text { erra } \\
\text { Indigena } \\
\text { (ha) }\end{array}$ & $\begin{array}{c}\text { Total de } \\
\text { áreas } \\
\text { sobreposi } \\
\text { cão } \\
\text { SIGEF } \\
\text { Total } \\
\end{array}$ & $\begin{array}{c}\text { SIGEF } \\
\text { Total sem } \\
\text { área } \\
\text { sobreposta } \\
\text { (ha) }\end{array}$ & $\begin{array}{c}\text { Oferta } \\
\text { Atual } \\
\text { SIGEF } \\
\text { Particular } \\
\text { sem } \\
\text { sobreposiç } \\
\text { ão } \\
\end{array}$ & $\begin{array}{c}\text { (\%)Ofert } \\
\text { a Atual } \\
\text { SIGEF } \\
\text { Particula } \\
\text { r sem } \\
\text { sobreposi } \\
\text { ção } \\
\end{array}$ & $\begin{array}{c}\text { Assenta } \\
\text { mento } \\
\text { (ha) }\end{array}$ & $\begin{array}{c}\text { Terra } \\
\text { Indígena } \\
\text { (ha) }\end{array}$ & $\begin{array}{l}\text { Área sem } \\
\text { cadastro na } \\
\text { UC (ha) }\end{array}$ & $\begin{array}{c}\text { (\%)Área } \\
\text { sem } \\
\text { cadastro } \\
\text { na UC } \\
\text { (ha) }\end{array}$ \\
\hline $\begin{array}{c}\text { PARNA da Serra da } \\
\text { Bodoquena }+ \\
\end{array}$ & MS & $76.975,51$ & 2,14 & $10.983,96$ & 14,27 & $4.414,16$ & 0,00 & 0,00 & $4.414,16$ & $6.569,80$ & $26.720,67$ & 0,00 & $26.720,67$ & 0,00 & 0,00 & 0,00 & 0,00 & $26.720,67$ & $26.720,67$ & 34,71 & 0,00 & 0,00 & $43.685,04$ & 56,75 \\
\hline $\begin{array}{c}\text { PARNA da Chapada dos } \\
\text { Veadeiros } * * \# \\
\end{array}$ & GO & $249.008,77$ & 6,93 & $128.367,08$ & 51,55 & $65.265,01$ & 0,00 & 0,00 & $65.265,01$ & $63.102,07$ & $75.358,08$ & $6.422,60$ & $81.780,68$ & 499,08 & 0,00 & 0,00 & 499,08 & $81.281,60$ & $74.859,00$ & 30,06 & 0,00 & 0,00 & $104.625,10$ & 42,02 \\
\hline $\begin{array}{l}\text { PARNA Grande Sertão } \\
\text { Veredas **\#+ }+ \\
\end{array}$ & MG & $0.851,60$ & 6,42 & $99.702,21$ & 43,19 & $33.192,05$ & 0,91 & 0,00 & $33.192,96$ & $66.509,25$ & $62.212,72$ & 0,00 & $62.212,72$ & 0,00 & 0,08 & 0,00 & 0,08 & $62.212,64$ & $62.212,64$ & 26,95 & 118,82 & 0,00 & $102.010,89$ & 44,19 \\
\hline $\begin{array}{c}\text { PARNA Nascentes do Rio } \\
\text { Parnaiba ***\# }\end{array}$ & $\begin{array}{c}\text { BA/TO/M } \\
\text { A/PI }\end{array}$ & $724.323,40$ & 20,15 & $310.669,03$ & 42,89 & $137.988,34$ & 0,00 & 0,00 & $137.988,34$ & $172.680,69$ & $175.944,13$ & $3.157,26$ & $179.101,40$ & $2.131,51$ & 0,00 & 0,00 & $2.131,51$ & $176.969,89$ & $173.812,62$ & 24,00 & 0,00 & 0,00 & $374.672,82$ & 51,73 \\
\hline \begin{tabular}{|c|}
$\begin{array}{c}\text { PARNA da Chapada das } \\
\text { Mesas ***\# }\end{array}$ \\
\end{tabular} & MA & $159.952,26$ & 4,45 & $68.663,30$ & 42,93 & $22.930,72$ & 0,00 & 0,00 & 930,72 & $45.732,58$ & $31.875,59$ & 0,00 & $31.875,59$ & 0,00 & 0,00 & 0,00 & 0,00 & $31.875,59$ & $31.875,59$ & 19,93 & 0,00 & 0,00 & $82.344,09$ & 51,48 \\
\hline $\begin{array}{l}\text { PARNA das Sempre- } \\
\text { Vivas }^{* * * * \#+} \\
\end{array}$ & MG & $124.155,18$ & 3,45 & $42.856,66$ & 34,52 & $13.949,20$ & 0,00 & 0,00 & $13.949,20$ & $28.907,46$ & $16.940,61$ & 0,00 & $16.940,61$ & 0,00 & 0,00 & 0,00 & 0,00 & $16.940,61$ & $16.940,61$ & 13,64 & 0,00 & 0,00 & $78.307,11$ & 63,07 \\
\hline $\begin{array}{c}\text { PARNA da Serra da } \\
\text { Canastra }{ }^{* * \#+} \\
\end{array}$ & MG & $197.813,50$ & 5,50 & $76.547,43$ & 38,70 & $12.391,25$ & 0,00 & 0,00 & $12.391,25$ & $64.156,18$ & $13.365,28$ & 0,00 & $13.365,28$ & 0,00 & 0,00 & 0,00 & 0,00 & $13.365,28$ & $13.365,28$ & 6,76 & 0,00 & 0,00 & $120.292,04$ & 60,81 \\
\hline $\begin{array}{l}\text { PARNA Cavernas de } \\
\text { Pernacu + }\end{array}$ & MG & $56.448,45$ & 1,57 & 563,1 & 45,29 & 54, & 0,00 & $11.241,65$ & 995,98 & 67,20 & $8.987,24$ & 0,00 & 87,24 & 0,00 & 0,00 & $6.417,94$ & $6.417,94$ & $2.569,30$ & 569,30 & 4,55 & 0,00 & $18.645,75$ & $3.666,20$ & 50,78 \\
\hline $\begin{array}{l}\text { PARNA da Serra das } \\
\text { Confusões**@+ } \\
\end{array}$ & PI & $823.846,95$ & 22,92 & $268.763,21$ & 32,62 & $12.510,40$ & 0,00 & 0,00 & $12.510,40$ & $256.252,81$ & $32.192,17$ & 0,00 & $32.192,17$ & 0,00 & 0,00 & 0,00 & 0,00 & $32.192,17$ & $32.192,17$ & 3,91 & 0,00 & 0,00 & $35.401,97$ & 64,99 \\
\hline $\begin{array}{c}\text { PARNA da Chapada dos } \\
\text { Guimarães*\#\#+ } \\
\end{array}$ & MT & $32.646,63$ & 0,91 & $7.860,75$ & 24,08 & $1.040,15$ & 0,00 & 0,00 & $1.040,15$ & $6.820,60$ & $1.104,91$ & 0,00 & $1.104,91$ & 0,00 & 0,00 & 0,00 & 0,00 & $1.104,91$ & $1.104,91$ & 3,38 & 0,00 & 0,00 & $24.721,12$ & 75,72 \\
\hline PARNA das Emas & GO & $132.784,54$ & 3,69 & $1.032,89$ & 0,78 & 78,07 & 0,00 & 0,00 & 78,07 & 954,82 & 305,82 & 0,00 & 305,82 & 0,00 & 0,00 & 0,00 & 0,00 & 305,82 & 305,82 & 0,23 & 0,00 & 0,00 & $131.523,91$ & 99,05 \\
\hline PARNA da Serra do Cipó & & & 0,88 & & & & & 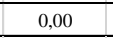 & &, 33 & 16,62 & 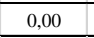 & & 0,00 & 00 & 0,00 & 0,00 & 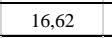 & 16,62 & 05 & 0,00 & 0,00 & $31.488,18$ & 9,52 \\
\hline PARNA de Brasilia \#+ & $\mathrm{DF} / \mathrm{GO}$ & $42.355,55$ & 1,18 & $30.129,23$ & 71,13 & 309,86 & 0,00 & 0,00 & 309,86 & \begin{tabular}{|l|}
$29.819,37$ \\
\end{tabular} & 5,34 & 304,70 & 310,04 & 0,00 & 0,00 & 0,00 & 0,00 & 310,04 & 5,34 & 0,01 & 0,00 & 0,00 & $12.226,14$ & 28,87 \\
\hline PARNA de Araguaiat & TO & $555.489,01$ & 15,45 & 34,01 & 0,01 & 0,00 & 0,00 & 20,19 & 20,19 & 13,82 & 0,04 & 0,00 & 0,04 & 0,00 & 0,00 & 0,00 & 0,00 & 0,04 & 0,04 & 0,00 & 0,18 & $553.124,40$ & $2.350,56$ & 0,42 \\
\hline $\begin{array}{l}\text { PARNA dos Lençóis } \\
\text { Maranhensest } \\
\end{array}$ & $\mathrm{MA}$ & $156.561,89$ & 4,36 & $1.344,23$ & 0,86 & 0,00 & 0,00 & 0,00 & 0,00 & $1.344,23$ & 0,00 & 0,00 & 0,00 & 0,00 & 0,00 & 0,00 & 0,00 & 0,00 & 0,00 & 0,00 & 0,00 & 0,00 & $155.217,66$ & 99,14 \\
\hline TOTAL & & \begin{tabular}{|l|}
$3.594 .852,37$ \\
\end{tabular} & 100,00 & $1.072 .653,56$ & 29,84 & $311.825,59$ & 0,91 & $11.261,84$ & $323.088,34$ & $749.565,22$ & \begin{tabular}{|l|l|}
$445.029,21$ \\
\end{tabular} & $9.884,56$ & \begin{tabular}{|l|l|}
$54.913,78$ \\
\end{tabular} & $2.630,59$ & 0,08 & $6.417,94$ & \begin{tabular}{|l|l|}
$9.048,61$ \\
\end{tabular} & $445.865,17$ & \begin{tabular}{|l|l|}
$435.980,60$ \\
\end{tabular} & 12,13 & 119,00 & $571.770,16$ & $1.827 .532,82$ & 50,84 \\
\hline
\end{tabular}

Fonte: Sigef, CNUC e CAR (março de 2018).

Notas: * Situação fundiária - totalmente regularizada, conforme informações no CNUC.

** Situação fundiária - parcialmente regularizada, conforme informações no CNUC.

*** Situação fundiária - não regularizada, conforme informações no CNUC.

+ Possui plano de manejo.

\# A área da UC possui ocupações.

@ A área da UC não possui ocupações. 
Considerando o indicador percentual de área sem cadastro em relação a cada Parna do Cerrado, o do Araguaia possui somente $0,42 \%$ de seu território sem cadastro de áreas. Isso ocorre porque sua área possui um conflito com terra indígena em cerca de 553.124,40 ha, o que representa mais de $99 \%$ de seu território, sendo que o percentual de área de oferta atual e potencial é inexistente $(0 \%)$, ou seja, não existem áreas de posse e propriedades cadastradas neste parque.

O Parna de Brasília possui o segundo indicador de área sem cadastro, cerca de 28,87\%. Como mencionado, este parque possui $71,13 \%$ de sua área cadastrada no CAR. Praticamente não existem áreas cadastradas como particulares e públicas certificadas no Sigef, nem assentamentos e terras indígenas. Dessa forma, pode-se sugestionar que esta área seja terra devoluta que está sendo ocupada por posseiros.

Considerando os dados narrados, o Parna Chapada dos Veadeiros pode ser considerado o parque com o menor indicador de área sem cadastro, ou seja, 42,02\%. Este Parna possui a quinta maior área de oferta potencial entre os Parnas do Cerrado, cerca de 25,34\% do seu território. Sua área cadastrada no CAR é de 51,55\%, sendo que, destas, 50,84\% têm sobreposição com as áreas certificadas no Sigef particular. A área de oferta atual também tem um percentual significativo, cerca de 30,06\% de seu território. De acordo com as informações fundiárias do CNUC, este parque está parcialmente regularizado, porém ainda possui ocupações.

No Parna Grande Sertão Veredas, 44,19\% de sua área está sem cadastro. Este parque possui ofertas atual e potencial de terras para o mercado de compensação de RL por doação de área, respectivamente, de 26,95\% e 28,81\% de sua área total. Este Parna possui plano de manejo e, de acordo com as informações fundiárias do CNUC, está parcialmente regularizado e não possui ocupações.

Os demais Parnas seguem a tendência da média dos Parnas do Cerrado: com 50\% ou mais de suas áreas sem cadastros, com áreas cadastradas no CAR maiores do que as áreas cadastradas como particulares no Sigef, refletindo numa oferta potencial, na maioria dos Parnas, maior do que a oferta atual.

Vale destacar o Parna da Serra da Bodoquena, que possui uma oferta potencial de 8,53\% de sua área cadastrada no CAR sem sobreposição de áreas, enquanto sua oferta atual é maior, na ordem de $34,71 \%$ de seu território, ou seja, de áreas particulares certificadas no Sigef sem sobreposição de áreas de assentamento e indígena. O indicador do percentual de áreas sobrepostas no CAR em relação ao Sigef é de 40,19\%. 
Os Parna das Emas, dos Lençóis Maranhenses e da Serra do Cipó possuem mais de 99\% de sua área sem cadastro no CAR e no Sigef. Estes parques praticamente não possuem áreas certificadas no Sigef e no CAR.

As médias, dos Parnas do Cerrado, dos indicadores de oferta atual e potencial de áreas para ingressarem no mercado de compensação de RL são, respectivamente, $12,13 \%$ e 20,85\%. Estes baixos percentuais indicam o limitado alcance do mercado de compensação de RL por doação de área de UC de domínio público para a consolidação territorial dos parques do Cerrado. Em outras palavras, somente $12,13 \%$ das áreas totais do parque poderão ser regularizadas por meio desse mercado. Para que ocorra a consolidação territorial dos Parnas do Cerrado, será necessária uma política pública de discriminação de terras devolutas, já que $50,84 \%$ da área destes parques estão sem cadastros.

Dentre as áreas cadastradas no CAR, somente 29,07\% está sobreposta com as áreas particulares certificadas no Sigef. Nesse sentido, uma política de discriminação de terras com o objetivo de alcançar a consolidação territorial dos Parnas do Cerrado poderá ser viabilizada por meio das informações do CAR, no sentido de se confirmar, neste cadastro, o que é propriedade privada, posse mansa e pacífica daquelas áreas de apossamento em terras públicas, ou seja, grilagem de terras devolutas.

\subsubsection{Ofertas atual e potencial de áreas para ingressarem no mercado de compensação de $R L$ por doação de área de UC de domínio público: uma análise das estações ecológicas (EEs) do bioma Cerrado e suas áreas sem cadastros}

As EEs no bioma Cerrado somam 28 UCs de domínio público, sendo que 23 são estaduais e 5 federais, representando uma área de 1.137.190,64 ha, que são 23,38\% do total da área de todas as UCs de domínio público do Cerrado.

As informações do CNUC em relação à situação fundiária das EEs atestam que 17,85\% destas UCs, ou seja, 5 estão parcialmente regularizadas (EEs Serra Geral do Tocantins, Iquê, Águas Emendadas, Santa Maria, Jardim Botânico de Brasília); 50\% das EEs estão totalmente regularizadas (Jataí, Assis, Serra das Araras, Paranapanema, Barreiro Rico, Ribeirão Preto, Angatuba, Pirapitinga, Mata do Jacaré, Itaberá, Bauru, Acauã, Avaré, Mogi Guaçu e Itirapina. A EE de Corumbá não está regularizada, segundo as informações do CNUC, e sobre as demais EEs não constam informações.

A maioria das EEs do Cerrado não possui terras certificadas no Sigef como públicas, nem assentamentos e terras indígenas. Nesses casos, a oferta de área atual para o mercado em 
análise é o mesmo indicador da área certificada como particular no Sigef. São poucas as EEs que possuem terras públicas certificadas no Sigef (Serra Geral do Tocantins, Serra das Araras e Águas Emendadas); somente a EE de Iquê possui terras indígenas e a EE de Uruçu-Uma possui assentamento. A Tabela 20 traz todas as informações das EEs do bioma Cerrado. 
Tabela 20 - Ofertas atual e potencial e áreas sem cadastro das estações ecológicas (EEs) do bioma Cerrado em hectares (dados de março de 2018)

\begin{tabular}{|c|c|c|c|c|c|c|c|c|c|c|c|c|c|c|c|c|c|c|c|c|c|c|c|c|c|}
\hline $\begin{array}{l}\text { Nome das Estaãôes } \\
\text { Ecológicas (EEs) }\end{array}$ & UF & Área UC (ha) & $\begin{array}{c}(\%) \text { da } \\
\text { UC na } \\
\text { Àrea } \\
\text { Total } \\
\text { UCs }\end{array}$ & CAR (ha) & $\begin{array}{l}\text { (\%) CAR na } \\
\text { UC }\end{array}$ & $\begin{array}{c}\mathrm{CAR} / \mathrm{SIGE} \\
\mathrm{F} \text { (ha) }\end{array}$ & $\begin{array}{l}\text { CAR/As } \\
\text { sentame } \\
\text { nto (ha) }\end{array}$ & $\begin{array}{c}\text { CAR/Te } \\
\text { rra } \\
\text { Indigena } \\
\text { (ha) }\end{array}$ & $\begin{array}{c}\text { Total de } \\
\text { área } \\
\text { sobreposiçã ã } \\
\text { O CAR (ha) }\end{array}$ & $\begin{array}{c}\text { Oferta } \\
\text { Potencial } \\
\text { CAR sem } \\
\text { sobreposi } \\
\text { ção (ha) }\end{array}$ & $\begin{array}{c}(\%) \\
\text { Oferta } \\
\text { Potencial } \\
\text { CAR sem } \\
\text { sobreposi } \\
\text { ção (ha) }\end{array}$ & $\begin{array}{c}\text { SIGEF } \\
\text { Particular } \\
\text { (ha) }\end{array}$ & $\begin{array}{l}\text { SIGEF } \\
\text { Público } \\
\text { (ha) }\end{array}$ & $\begin{array}{l}\text { SIGEF } \\
\text { Total (ha) }\end{array}$ & $\begin{array}{l}\text { SIGEF } \\
\text { Público/ } \\
\text { Particula } \\
\text { r (ha) }\end{array}$ & $\begin{array}{l}\text { SIGEF/A } \\
\text { ssentam } \\
\text { ento (ha) }\end{array}$ & $\begin{array}{c}\text { SIGEF/T } \\
\text { erra } \\
\text { Indigena } \\
\text { (ha) }\end{array}$ & $\begin{array}{c}\text { Total de } \\
\text { areas } \\
\text { sobrepo } \\
\text { sicão } \\
\text { siGEF } \\
\text { Total } \\
\text { (ha) }\end{array}$ & $\begin{array}{c}\text { SIGEF } \\
\text { Total sem } \\
\text { área } \\
\text { sobreposta } \\
\text { (ha) }\end{array}$ & $\begin{array}{c}\text { Oferta } \\
\text { Atual } \\
\text { StGEF } \\
\text { Particular } \\
\text { sem } \\
\text { sobre posicõo } \\
\text { es }\end{array}$ & $\begin{array}{c}\text { (\%) Oferta } \\
\text { Atual } \\
\text { StGEF } \\
\text { Particular } \\
\text { sem } \\
\text { sobreposiçõ } \\
\text { es }\end{array}$ & $\begin{array}{c}\text { Assenta } \\
\text { mento } \\
\text { (ha) }\end{array}$ & $\begin{array}{c}\text { Terra } \\
\text { Indigena } \\
\text { (ha) }\end{array}$ & $\begin{array}{l}\text { Área sem } \\
\text { cadastro na } \\
\text { UC (ha) }\end{array}$ & $\begin{array}{c}\text { (\%)Área } \\
\text { sem } \\
\text { cadastro } \\
\text { na UC } \\
\text { (ha) }\end{array}$ \\
\hline EE de Uruçúu-Uma + & PI & $135.125,38$ & 11,88 & $41.424,27$ & 30,66 & $30.611,79$ & 123,40 & 0,00 & $30.735,19$ & $10.689,08$ & 7,91 & $73.197,52$ & 0,00 & $73.197,52$ & 0,00 & 0,00 & 0,00 & 0,00 & $73.197,52$ & $73.197,52$ & 54,17 & 129,88 & 0,00 & $51.108,90$ & 37,82 \\
\hline $\begin{array}{l}\text { EE Serra Geral do } \\
\text { Tocantins:**@@ }\end{array}$ & ВА/ТО & $707.089,02$ & 62,18 & $130.044,38$ & 18,39 & $60.865,64$ & 0,00 & 0,00 & $60.865,64$ & $69.178,74$ & 9,78 & $1833.245,89$ & $19.566,00$ & $202.811,89$ & $5.553,61$ & 0,00 & 0,00 & $5.553,61$ & $197.258,28$ & $177.692,28$ & 25,13 & 0,00 & 0,00 & $440.651,99$ & 62,32 \\
\hline 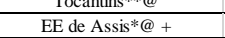 & $\mathrm{SP}$ & $1.747,75$ & 0,15 & 29,55 & 1,69 & 19,49 & 0,00 & 0,00 & 19,49 & 10,06 & 0,58 & 35,76 & 0,00 & 35,76 & 0,00 & 0,00 & 0,00 & 0,00 & 35,76 & 35,76 & 2,05 & 0,00 & 0,00 & 1.70193 & 97,38 \\
\hline EE do Barreiro Rico *@ & $\frac{\mathrm{SP}}{\mathrm{SP}}$ & & $0,0,02$ & & 1,09 & $\frac{1,4,49}{2,02}$ & 0,0 & 00,000 & $\frac{1,4,49}{2,02}$ & $\frac{10,00}{12,92}$ & 0,08 & 3,10 & 0,00 & 39,10 & 0,00 & $0, \infty$ & 0,00 & & & & 2,05 & & 0,00 & & $9,1,80$ \\
\hline$\frac{\mathrm{Eedo} \mathrm{Ba}}{\mathrm{EE} \mathrm{dc}}$ & SP & & $0, \frac{0,7}{0.7}$ & & & 71. & & 0,000 & $\frac{2,4}{71}$ & $\frac{12}{208}$ & $\frac{4,04}{2,32}$ & 83, & & & 0,000 & & 0,000 & & & & & & & & \\
\hline EE de & $\mathrm{SP}$ & 3.16 & 0,28 & & & 19,22 & 0, & 0,00 & 19,2 & 40, & 1,27 & 25, & & $\frac{.05}{25}$ & $\frac{0,4}{0,4}$ & 0,00 & 0,00 & & 25 & & & 00 & & & 92 \\
\hline EE de Iquêै**\# & MT & $215.973,63$ & 18,99 & & & 32,91 & & 22,66 & 55 & $4.835,67$ & $\frac{2,2,24}{2,24}$ & $\frac{2.600}{1.650,30}$ & & & 0,4 & 0,0 & 0,00 & & $\frac{2.65}{1.65}$ & $\frac{2.65}{1.656}$ & & 0,00 & & & 38 \\
\hline EE de Paranapanema $* @$ & $\frac{\mathrm{M} 1}{\mathrm{SP}}$ & $\frac{2159,3,65}{634,52}$ & $\frac{1,899}{0,06}$ & $\frac{4.89}{0,8}$ & & $\frac{32,0}{0,0}$ & 0 & $\frac{22,00}{0,00}$ & $\frac{35,}{0,6}$ & $\begin{array}{l}4.8,5,07 \\
0,80\end{array}$ & $\frac{2,24}{0,13}$ & $1.630,50$ & & $\frac{1.000,30}{3,38}$ & 0 & & $0, s$ & & $\frac{1.05}{3,}$ & $1.050,30$ & & 00 & & & 8,34 \\
\hline EE de Santa $\mathrm{M}$ : & $\frac{\mathrm{SP}}{\mathrm{SP}}$ & & 0,00 & & & & & $\begin{array}{l}0,000 \\
0,00\end{array}$ & & & $\frac{2,1}{2,1}$ & & & $\frac{3,}{4,}$ & 0 & & 0,8 & & & $\frac{3,}{4,}$ & & 00 & & & $\begin{array}{l}97,34 \\
97,51\end{array}$ \\
\hline & $\frac{\mathrm{SP}}{\mathrm{SP}}$ & & 0,012 & & & & & $\frac{0,6}{0,6}$ & & & & & & & 0 & & 0,000 & & & & & & & & $\begin{array}{l}97,51 \\
97,53 \\
\end{array}$ \\
\hline EL Aguás Emendadas**@@+ & $\frac{\mathrm{SF}}{\mathrm{DF}}$ & & 0,01 & $3.829,39$ & .71 & & & $\frac{0,000}{0,00}$ & & & $\begin{array}{l}2,24 \\
39,52 \\
-12\end{array}$ & & 206,26 & & $\frac{0,000}{0,00}$ & & 0,000 & & & & $\frac{0,2}{0,1}$ & & & & $\begin{array}{l}58,03 \\
58,09 \\
\end{array}$ \\
\hline $\begin{array}{l}\text { A Aguas Emenciadas } *+\infty \\
\text { E Serra das Araras } * \text { \& }\end{array}$ & $\frac{\mathrm{DF}}{\mathrm{MT}}$ & $\frac{9.18}{27.1}$ & $\frac{0,01}{2,39}$ & $\begin{array}{l}3.82,39 \\
1.622,90\end{array}$ & 11 & $\frac{20}{1.5}$ & 0, & $0,0,00$ & $\frac{200,84}{1.582,90}$ & $\begin{array}{l}3.682,03 \\
40,00 \\
\end{array}$ & $\frac{3,52}{0,15}$ & $\frac{12,4}{339,}$ & $\begin{array}{ll}270,20 \\
27.92 \\
\end{array}$ & $\frac{21,963}{27.860,69}$ & $\frac{0,00}{326,34}$ & 0 & $\begin{array}{l}0,000 \\
0,00\end{array}$ & & $\frac{21,903}{27.534,35}$ & & $\frac{0,1}{0,6}$ & $\frac{0,00}{0,00}$ & & & $\frac{38,09}{0,00}$ \\
\hline EE Estadual de Sagarana & MG & & 0,2 & & & & & 0,0 & 0, & & 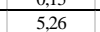 & 0,6 & 0,00 & 0,604 & 54 & & 0 & & 0, & & & & & & 71 \\
\hline EE Angatuba *@ & SP & & & & & $0, \mathrm{~s}$ & & 0,0 & & & 1, & & & 0 & & & 0 & & & & & & & & 98,82 \\
\hline $\mathrm{EE} \mathrm{do}$ & $\mathrm{BA}$ & & & & & & & 0, & & & 3 & & & & & & 0 & & & & & & & & 60 \\
\hline EE de Pir & MG & & 0,1 & & & & & 0,0 & & & 0 & & & & & & 0 & & & & & & & & 100,00 \\
\hline E da Mata d & MG & & $\frac{0,}{0,4}$ & & & & & 0,0 & & & & & & & & & 0 & & & & & & & & 93,04 \\
\hline EE de Corumbá $* * * @ @$ & MG & & & 291 & & & & 0,0 & & & & & & & & & 0 & & & & & & & & 5,92 \\
\hline & SP & & & & & & & 0,0 & & & $0, s$ & & & & & & $\frac{0,4}{0,4}$ & & & & & & & & 100,00 \\
\hline $\mathrm{EE} \mathrm{Ma}$ & $\frac{\mathrm{SP}}{\mathrm{SP}}$ & $\frac{8}{8}$ & & & & $\frac{0,6}{0,6}$ & & 0,4 & & & 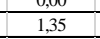 & & & & & & 0,4 & & & & & $\frac{0,}{0 .}$ & & & 98,65 \\
\hline EE Itaberá* & $\begin{array}{ll}\mathrm{SP} \\
\mathrm{SP}\end{array}$ & 194,27 & $\frac{0,01}{0.02}$ & $\frac{1,11}{12,69}$ & $\frac{1,53}{6.53}$ & 0. & 0,00 & 0,00 & & 12 & 6,5 & 0,0 & 0 & 0,6 & 0.00 & 0,00 & 0 & 0 & $\frac{0,4}{0,4}$ & & & 0 & & 181,58 & 93,47 \\
\hline$\frac{\mathrm{EI}}{\mathrm{EF}}$ & $\frac{\mathrm{SP}}{\mathrm{SP}}$ & $\begin{array}{l}194,27 \\
308,86 \\
\end{array}$ & 0,02 & 39,45 & 12,77 & 0,00 & 0,00 & 0,00 & 0,00 & 39,45 & $\frac{0,3}{12,7}$ & 0,00 & 0,00 & 0,00 & 0,000 & 0,00 & 0,00 & 0,00 & 0,00 & 0,00 & 0,00 & 0,00 & 0,00 & $\frac{101,08}{269,41}$ & $\begin{array}{l}9,247 \\
87,23 \\
\end{array}$ \\
\hline $\begin{array}{l}\text { EE Jardim Botânico de } \\
\text { Brasilia**e@ }\end{array}$ & $\mathrm{DF}$ & $4.502,48$ & 0,40 & $1.750,84$ & 38,89 & 0,00 & 0,00 & 0,00 & 0,00 & $1.750,84$ & 38,89 & 0,00 & 0,00 & 0,00 & 0,00 & 0,00 & 0,00 & 0,00 & 0,00 & 0,00 & 0,00 & 0,00 & 0,00 & $2.751,64$ & 61,11 \\
\hline EE de Acauă *@ & MG & $6.455,18$ & 0,57 & 881,54 & 13,66 & 0,4 & 0,0 & 0,00 & 0,00 & 881,54 & 13. & 0,00 & 0,00 & 0,00 & 0,00 & 0,00 & 0,00 & 0,00 & 0,00 & 0,0 & 0,00 & 0,00 & 00 & $5.573,64$ & 86,34 \\
\hline EE de Itapeva & $\mathrm{SP}$ & $\frac{0.49}{99}$ & $\frac{0,4}{0,4}$ & $\frac{60}{25}$ & $\frac{1,000}{25,43}$ & $\frac{0,00}{0,00}$ & $\frac{0,00}{0,00}$ & 0 & $\frac{0,00}{0,00}$ & 00 & $\frac{15}{25}$ & & $\frac{0,00}{0,00}$ & 0,00 & 0,00 & $\frac{0,00}{0,00}$ & $\frac{0,00}{0,00}$ & $\frac{0,00}{0,00}$ & & & & 0,000 & & $\frac{3.5}{7 .}$ & 74,57 \\
\hline EE de Avaré $* \#$ & $\mathrm{SP}$ & $\frac{72}{72}$ & $\frac{0,6}{0,6}$ & 5 & 0,8 & $\begin{array}{l}0,000 \\
0,00\end{array}$ & 0,00 & $\frac{0,00}{0,00}$ & 0 & $\frac{5,9}{5,9}-10$ & 0,8 & $0,0,00$ & 0,00 & 0, & 0,0 & $\frac{0,00}{0,00}$ & 0,00 & $\frac{0,00}{0,00}$ & 0,4 & $\frac{0,6}{0, c}$ & 0,00 & 0,00 & 0,00 & 71 & $\begin{aligned} 49,51 \\
99,18\end{aligned}$ \\
\hline EE de Mogi Guaçu *@ + & $\mathrm{SP}$ & 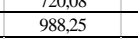 & $\frac{0,6}{0,6}$ & $\frac{12}{12}$ & $\frac{0,4}{1,2}$ & $\frac{0,0}{0,0}$ & $0,0,0$ & $0,0,00$ & 0 & 12 & $\frac{0,8}{1,}$ & $0,0,00$ & $\frac{0,000}{0,00}$ & 0, & 0,0 & $\frac{0,000}{0,00}$ & $\frac{0,0}{0,0}$ & 0 & 0,4 & 0 & 0, & 0 & & 976 & $\begin{array}{l}9 y, 16 \\
98,77 \\
\end{array}$ \\
\hline EE de Itriapina *@ & SP & $2.205,71$ & 0,19 & 199,91 & 9,06 & 0,00 & 0,00 & 0,00 & 0,00 & 199,91 & 9,06 & 0,00 & 0,00 & 0,00 & 0,00 & 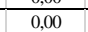 & 00 & 0,00 & 0,00 & 0,00 & 0,00 & 0,00 & 0,00 & $2.005,80$ & 90,94 \\
\hline TOTAL & & $1.137 .190,64^{\prime \prime}$ & 100,00 & $185.786,68$ & 16,34 & $93.407,80$ & 123,40 & 22,66 & 93.553,86 & $92.232,82$ & 8,11 & $258.603,15$ & $47.293,18$ & $305.896,33$ & $5.879,95$ & 0,000 & 0,00 & $5.879,95$ & $300.016,38$ & $252.723,20$ & 22,22 & \begin{tabular}{|l|l|}
129,88 \\
\end{tabular} & $208.661,29$ & $536.150,27$ & 47,15 \\
\hline
\end{tabular}

Fonte: Sigef, CNUC e CAR (março de 2018).

Notas: * Situação fundiária - totalmente regularizada, conforme informações no CNUC.

** Situação fundiária - parcialmente regularizada, conforme informações no CNUC.

*** Situação fundiária - não regularizada, conforme informações no CNUC.

+ Possui plano de manejo.

\# A área da UC possui ocupações.

@ A área da UC não possui ocupações. 
A EE da Serra Geral do Tocantins é a maior área entre estas UC, com 707.089,02 ha, representando 62,18\% da área total das EEs do Cerrado, seguida da EE de Iquê com 215.973,63 ha $(18,99 \%)$ e da EE Uruçuí-Uma com área de 135.125,38 ha, representando 11,88\% da área total das EEs do Cerrado. Essas três EEs em área representam 93,05\% da área total das EEs do bioma Cerrado.

Da área total das EEs do Cerrado, 258.603,15 ha são áreas particulares certificadas no Sigef. Destas áreas, descontadas as sobreposições de áreas certificadas como públicas, terras indígenas e assentamentos, tem-se uma área de 252.723,20 ha, representando 22,22\% da área total das EEs do Cerrado. Estas são as áreas que, atualmente (até a data de março de 2018), podem ser ofertadas no mercado de compensação de RL por doação de área de UC de domínio público.

As EEs Serra Geral do Tocantins e de Uruçu-Uma possuem os maiores percentuais de oferta atual de área para ser ofertada no mercado de compensação de RL por doação de área de UC de domínio público, respectivamente, $25,13 \%$ e 54,17\% de suas áreas totais. A terceira EE com maior percentual de oferta de área atual é a de Assis, com 2,05\% de sua área total. As demais EEs possuem percentuais de áreas atuais, que são aquelas certificadas como particulares, sem sobreposição de áreas públicas, indígenas e assentamentos, menores do que $1 \%$, chegando a $0 \%$.

As áreas que foram cadastradas no CAR como posses e/ou propriedades privadas somam um total de 185.786,68 ha, correspondendo a um percentual de 29,84\% de sua área total. Estas áreas, descontadas as sobreposições de áreas privadas, públicas certificadas no Sigef, assentamentos e terras indígenas, resultam numa área de 92.232,82 ha, representando $8,11 \%$ da área total das EEs do Cerrado. Como o CAR não especifica o que é posse e propriedade, não se pode analisar a situação de posse e propriedade desta dessa área. Assim, esta área pode ser tanto de propriedades privadas que ainda não realizaram a certificação do georreferenciamento no Sigef como áreas com conflitos fundiários e/ou burocráticos.

A EE de Corumbá possui 94,08\% de seu território cadastrado no CAR sem sobreposição de áreas, ou seja, da sua área total de 309,82 ha, 291,51 ha estão cadastrados no CAR e não apresentam sobreposição de áreas. Esta EE também não possui cadastro no Sigef de áreas particulares ou públicas, nem áreas de assentamentos e terras indígenas. De acordo com as informações do CNUC, esta EE não está ocupada e não está regularizada.

As EEs das Águas Emendadas e do Jardim Botânico de Brasília possuem respectivamente $39,52 \%$ e $38,89 \%$ de suas áreas de oferta potencial para o mercado de terras 
de compensação de RL por doação de área de UC. Vale ressaltar que estas áreas também não possuem cadastro de áreas certificadas no Sigef, nem terra indígena e assentamento.

As áreas que estão sem cadastro no CAR e no Sigef (pública e privada) e não possuem registros de assentamentos e de terras indígenas somam um total de 536.150,27 ha. A porcentagem desta área em relação à área total das EEs do Cerrado é de 47,15\%.

A maioria das EEs, cerca de 18, tem entre $90 \%$ e $100 \%$ de suas áreas sem cadastros no Sigef e no CAR, e 2 (EE de Bauru e Acauã) possuem percentuais, respectivamente, de 87,23\% e 86,34\% de áreas sem cadastros. Destas 20 EEs, de acordo com as informações fundiárias do CNUC, 12 estão totalmente regularizadas e 2 parcialmente regularizadas. Este pode ser o fator principal destas áreas estarem sem cadastros.

As EEs de Corumbá, de Iquê e Serra das Araras possuem um baixo percentual de área sem cadastro em relação à UC, respectivamente de 5,92\%, 0,38\% e 0\%. A EE de Corumbá possui grande parte de sua área cadastrada no CAR, a EE de Iquê possui 96,4\% de seu território sobreposto com área indígena, e a EE Serra das Araras possui praticamente todo o seu território certificado como área pública no Sigef. A situação fundiária desta EE está como totalmente regularizada no CNUC.

A oferta de terras para o mercado de compensação de RL por doação de área de UC de domínio público das EEs, até a data de março de 2018, pode contribuir com uma área de 252.723,20 ha de terras particulares certificadas no Sigef para o mercado de terras de compensação de RL por doação de área de UC de domínio público.

Cerca de 47,15\% das terras das EEs do Cerrado estão sem cadastros no CAR e no Sigef e não possuem cadastros de assentamentos e terras indígenas. Existe a ressalva de que muitas destas EEs estão totalmente regularizadas, o que pode explicar a não existência de cadastros de terras como posse e/ou propriedade.

Nesse sentido, a consolidação territorial das EEs depende menos desse mercado potencial, já que poucas áreas poderão ser regularizadas por meio dele. Este fato direciona para uma ação de discriminação de terras públicas, que realize um levantamento fundiário para descobrir as terras devolutas (que são públicas), para cadastrá-las no registro de imóveis no nome do órgão gestor das EEs.

6.4.3 Ofertas atual e potencial de áreas para ingressarem no mercado de compensação de $R L$ por doação de área de UC de domínio público: uma análise das reservas extrativistas (Resex) do bioma Cerrado e suas áreas sem cadastros 
As Resex no bioma Cerrado somam 6 UCs de domínio público, sendo que todas são federais e representam uma área de 89.024,69 ha, que é 1,83\% do total da área das UCs de domínio público do Cerrado. Destas Resex, somente a Chapada Limpa e a Extremo Norte do estado do Tocantins possuem áreas de assentamentos. Esta última também possui cadastro de terras públicas certificadas no Sigef, que representa grande parte de seu território, com a Resex Mata Grande. Não existe cadastro de terras indígenas nas Resex do Cerrado.

Do total das áreas das Resex, 20.819,56 ha estão cadastradas como área particular no Sigef, representando $23,39 \%$ da área total das Resex do bioma Cerrado. Esta é a oferta atual de áreas para o mercado de compensação de RL por doação de área de UC de domínio público.

A oferta potencial de área para este mercado de compensação de RL é de 29.758,55 ha, o que representa $33,43 \%$ de sua área total.

As áreas sem cadastros nas Resex do Cerrado formam 28.136,79 ha, cerca de 31,61\% da área total destas UCs. A Tabela 21 mostra estas informações. 
Tabela 21 - Ofertas atual e potencial e áreas sem cadastro das reservas extrativistas (Resex) do bioma Cerrado em hectares (dados de março de 2018)

\begin{tabular}{|c|c|c|c|c|c|c|c|c|c|c|c|c|c|c|c|c|c|c|c|c|c|c|c|c|c|}
\hline $\begin{array}{c}\text { Nome das } \\
\text { Reservas } \\
\text { Extrativistas(RE } \\
\text { SEXs) }\end{array}$ & UF & $\begin{array}{c}\text { Área UC } \\
\text { (ha) }\end{array}$ & $\begin{array}{c}(\%) \text { da } \\
\text { UC na } \\
\text { Àrea } \\
\text { Total } \\
\text { UCs }\end{array}$ & CAR (ha) & $\begin{array}{l}(\%) \\
\text { CAR } \\
\text { (ha) }\end{array}$ & $\begin{array}{c}\text { CAR/SI } \\
\text { GEF (ha) }\end{array}$ & $\begin{array}{c}\text { CAR/As } \\
\text { sentame } \\
\text { nto (ha) }\end{array}$ & $\begin{array}{c}\text { CAR/Te } \\
\text { rra } \\
\text { Indigena } \\
\text { (hectare } \\
\text { s) }\end{array}$ & $\begin{array}{l}\text { Total de } \\
\text { área } \\
\text { sobrepo } \\
\text { sição } \\
\text { CAR }\end{array}$ & $\begin{array}{c}\text { Oferta } \\
\text { Potencia } \\
\text { ICAR } \\
\text { sem } \\
\text { sobrepo } \\
\text { sição } \\
\text { (ha) }\end{array}$ & $\begin{array}{c}(\%) \\
\text { Oferta } \\
\text { Potencia } \\
\text { I CAR } \\
\text { sem } \\
\text { sobrepo } \\
\text { sição } \\
\text { (ha) }\end{array}$ & $\begin{array}{l}\text { SIGEF } \\
\text { Particula } \\
\mathbf{r} \text { (ha) }\end{array}$ & $\begin{array}{l}\text { SIGEF } \\
\text { Público } \\
\text { (ha) }\end{array}$ & $\begin{array}{c}\text { SIGEF } \\
\text { Total }\end{array}$ & $\begin{array}{c}\text { SIGEF } \\
\text { Público/ } \\
\text { Particula } \\
\mathbf{r} \text { (ha) }\end{array}$ & $\begin{array}{l}\text { SIGEF/A } \\
\text { ssentam } \\
\text { ento (ha) }{ }^{1}\end{array}$ & $\begin{array}{l}\text { SIGEF/T } \\
\text { erra } \\
\text { Indígena } \\
\text { (ha) }\end{array}$ & $\begin{array}{c}\text { Total de } \\
\text { áreas } \\
\text { sobrepo } \\
\text { sição } \\
\text { SIGEF } \\
\text { Total } \\
\text { (ha) }\end{array}$ & $\begin{array}{c}\text { SIGEF } \\
\text { Total } \\
\text { sem área } \\
\text { sobrepo } \\
\text { sta (ha) }\end{array}$ & $\begin{array}{l}\text { Oferta } \\
\text { Atual } \\
\text { SIGEF } \\
\text { Particula } \\
\text { r sem } \\
\text { sobrepo } \\
\text { sições } \\
\text { (ha) }\end{array}$ & $\begin{array}{c}\text { (\%) } \\
\text { Oferta } \\
\text { Atual } \\
\text { SIGEF } \\
\text { Particula } \\
\text { r sem } \\
\text { sobrepo } \\
\text { sições } \\
\text { na área } \\
\text { da UC }\end{array}$ & $\begin{array}{c}\text { Assenta } \\
\text { mento } \\
\text { (ha) }\end{array}$ & $\begin{array}{c}\text { Terra } \\
\text { Indígena } \\
\text { (ha) }\end{array}$ & $\begin{array}{c}\text { Área } \\
\text { sem } \\
\text { cadastro } \\
\text { na UC } \\
\text { (ha) }\end{array}$ & $\begin{array}{c}\text { (\%)Área } \\
\text { sem } \\
\text { cadastro } \\
\text { na UC } \\
\text { (ha) }\end{array}$ \\
\hline $\begin{array}{l}\text { RESEX Mata } \\
\text { Grande \# }\end{array}$ & MA & $11.431,53$ & 12,84 & $11.242,70$ & 98,35 & $5.432,74$ & 0,00 & 0,00 & $5.432,74$ & $5.809,96$ & 50,82 & $4.161,98$ & $3.116,70$ & 7.278,68 & $1.823,75$ & 0,00 & 0,00 & $1.823,75$ & $5.454,93$ & $2.338,23$ & 20,45 & 0,00 & 0,00 & 166,64 & 1,46 \\
\hline $\begin{array}{c}\text { RESEX Chapada } \\
\text { Limpa }\end{array}$ & MA & $11.973,02$ & 13,45 & $11.735,93$ & 98,02 & 0,00 & 46,00 & 0,00 & 46,00 & $11.689,93$ & 97,64 & 0,00 & 0,00 & 0,00 & 0,00 & 0,00 & 0,00 & 0,00 & 0,00 & 0,00 & 0,00 & 45,42 & 0,00 & 237,67 & 1,99 \\
\hline $\begin{array}{c}\text { RESEX de } \\
\text { Recanto das } \\
\text { Araras de Terra } \\
\text { Ronca \# } \\
\end{array}$ & GO & $12.349,33$ & 13,87 & $12.349,33$ & 100,00 & $3.634,75$ & 0,00 & 0,00 & $3.634,75$ & $8.714,58$ & 70,57 & $3.639,59$ & 0,00 & $3.639,59$ & 0,00 & 0,00 & 0,00 & 0,00 & $3.639,59$ & $3.639,59$ & 29,47 & 0,00 & 0,00 & 0,00 & 0,00 \\
\hline $\begin{array}{l}\text { RESEX Extremo } \\
\text { Norte do Estado } \\
\text { do Tocantins }\end{array}$ & TO & $9.070,05$ & 10,19 & $6.808,03$ & 75,06 & $4.841,87$ & 63,86 & 0,00 & $4.905,73$ & $1.902,30$ & 20,97 & $1.004,09$ & $7.135,00$ & $8.139,09$ & 989,96 & 109,90 & 0,00 & $1.099,86$ & $7.039,23$ & 0,00 & 0,00 & 108,44 & 0,00 & 20,07 & 0,22 \\
\hline $\begin{array}{c}\text { RESEX Lago do } \\
\text { Cedro \# } \\
\end{array}$ & GO & $17.179,07$ & 19,30 & $2.588,35$ & 15,07 & 965,64 & 0,00 & 0,00 & 965,64 & $1.622,71$ & 9,45 & $14.838,61$ & 0,00 & $14.838,61$ & 0,00 & 0,00 & 0,00 & 0,00 & $14.838,61$ & $14.838,61$ & 86,38 & 0,00 & 0,00 & 717,75 & 4,18 \\
\hline $\begin{array}{c}\text { RESEX Marinha } \\
\text { do Delta do } \\
\text { Parnaiba }\end{array}$ & PI & $27.021,69$ & 30,35 & 19,20 & 0,07 & 0,13 & 0,00 & 0,00 & 0,13 & 19,07 & 0,07 & 3,13 & 0,00 & 3,13 & 0,00 & 0,00 & 0,00 & 0,00 & 3,13 & 3,13 & 0,01 & 0,00 & 0,00 & $26.999,50$ & ) 99,92 \\
\hline TOTAL & & $89.024,69$ & 100,00 & $44.743,54^{\prime \prime}$ & 50,26 & $14.875,13$ & 109,86 & 0,00 & $14.984,99$ & $29.758,55$ & 33,43 & $23.647,40$ & $10.251,70$ & $33.899,10$ & $2.813,71$ & 109,90 & 0,00 & $2.923,61$ & $30.975,49$ & $20.819,56$ & 23,39 & \begin{tabular}{ll|}
153,86 \\
\end{tabular} & 0,00 & $28.136,79$ & 31,61 \\
\hline
\end{tabular}

Fonte: Sigef, CNUC e CAR (março de 2018).

Notas: * Situação fundiária - totalmente regularizada, conforme informações no CNUC.

** Situação fundiária - parcialmente regularizada, conforme informações no CNUC.

*** Situação fundiária - não regularizada, conforme informações no CNUC.

+ Possui plano de manejo.

\# A área da UC possui ocupações.

@ A área da UC não possui ocupações. 
Existe um desvio padrão elevado entre os indicadores médios. A Resex Lago do Cedro, com uma área de 17.179,07 ha, possui 86,38\% desta área cadastrada como particular no Sigef e 9,45\% como oferta potencial, ou seja, terras cadastradas no CAR sem sobreposição de áreas. Seu percentual de terras sem cadastros é de $4,18 \%$. De acordo com as informações do CNUC, esta UC possui ocupações.

Em contrapartida, a Resex da Chapada Limpa não possui áreas certificadas como particulares no Sigef. A Resex do Extremo Norte do estado do Tocantins possui uma área total de 9.070,05 ha, sendo que destes 7.135,00 ha estão certificados como área pública no Sigef e do montante de área certificada como particular no Sigef, que é de 1.004,09 ha, 989,96 ha estão sobrepostos com as áreas certificadas públicas. Dada a elevada porcentagem de áreas cadastradas nestas duas UCs, a Resex Extremo Norte do estado do Tocantins possui somente 0,22\% de seu território sem cadastros, enquanto a Resex Chapada Limpa possui um baixo percentual de áreas sem cadastros, que é de $1,99 \%$ de seu território.

As Resex da Mata Grande e Recanto das Araras de Terra Rouca possuem, respectivamente, $20,45 \%$ e $29,47 \%$ de oferta de área atual para o mercado de compensação de RL. Suas áreas de oferta potenciais são, respectivamente, $50,82 \%$ e 70,57\%. O percentual de áreas sem cadastros nestas UCs são, respectivamente, $1,46 \%$ e $0 \%$, que refletem o elevado percentual de áreas cadastradas no CAR sem sobreposição de áreas. Vale lembrar que as Resex Mata Grande e Recanto das Araras de Terra Rouca possuem ocupações de acordo com as informações do CNUC.

A Resex Marinha do Delta do Paraíba, com uma área total de 27.021,69 ha, que representa 30,35\% do território das Resex do Cerrado, possui somente 19,07 ha de área cadastrada no CAR sem sobreposição das demais áreas (oferta potencial) e 3,13 ha de áreas particulares certificadas no Sigef, justificando uma área com 99,92\% sem cadastros.

Nas informações do CNUC, não consta a situação fundiária das Resex do Cerrado, porém a não existência de áreas cadastradas na Resex Marinha do Delta do Paraíba e o elevado percentual de área certificada no Sigef como pública, na Chapada Limpa, sugerem que estas Resex estejam regularizadas.

No mercado de compensação de RL por doação de área de UC de domínio público, 23,39\% da área das Resex podem participar como oferta atual e efetiva neste mercado, sendo suas áreas regularizadas, ou seja, passando do domínio particular para o domínio do órgão gestor das Resex.

O restante das áreas das Resex que necessitam de regularização fundiária para que ocorra a consolidação territorial das Resex do Cerrado estariam nas ações de discriminação das 
terras cadastradas no CAR, para aferir quais destas realmente são propriedades, posses mansas e pacíficas que podem ser ofertadas no mercado de compensação de RL analisado, daquelas que são áreas com posses que podem estar sendo griladas.

6.4.4 Ofertas atual e potencial de áreas para ingressarem no mercado de compensação de RL por doação de área de UC de domínio público: análise das florestas nacionais (Flonas) do bioma Cerrado e suas áreas sem cadastros

As Flonas, no bioma Cerrado, somam 7 UCs de domínio público, com área de 29.281,23 ha, que é $0,60 \%$ do total da área das UCs de domínio público do Cerrado. Do total das áreas das Flonas, somente 219,52 ha estão cadastrados como área particular no Sigef, representando 0,75\% da área total das Flonas do bioma Cerrado. Esta é a oferta atual de áreas para o mercado de compensação de RL por doação de área de UC de domínio público.

A oferta potencial de área para este mercado de compensação de RL, que é a área cadastrada no CAR sem sobreposição com as demais áreas, é de 16.349,49 ha, o que representa $55,84 \%$ de sua área total.

As áreas sem cadastros nas Flonas do Cerrado formam 7.262,73 ha, cerca de 24,80\% da área total destas UCs. A Tabela 22 mostra estas informações. 
Tabela 22 - Ofertas atual e potencial e áreas sem cadastro das florestas nacionais (Flonas) do bioma Cerrado em hectares (dados de março de 2018)

\begin{tabular}{|c|c|c|c|c|c|c|c|c|c|c|c|c|c|c|c|c|c|c|c|c|c|c|c|c|c|}
\hline $\begin{array}{c}\text { Nome das } \\
\text { Florestas } \\
\text { Nacionais(FLON } \\
\text { As) }\end{array}$ & UF & $\begin{array}{c}\underset{\text { Área UC }}{\text { (ha) }} \\
\text { (has }\end{array}$ & $\begin{array}{l}(\%) \text { da } \\
\text { UC na } \\
\text { Àrea } \\
\text { Total } \\
\text { UCs }\end{array}$ & CAR (ha) & $\begin{array}{l}\text { (\%) CAR } \\
\text { (ha) }\end{array}$ & $\begin{array}{l}\text { CAR/SI } \\
\text { GEF (ha) }\end{array}$ & $\begin{array}{l}\text { CAR/As } \\
\text { sentame } \\
\text { nto (ha) }\end{array}$ & $\begin{array}{c}\mathrm{CAR} / \mathrm{Te} \\
\text { rra } \\
\text { Indígena } \\
\text { (ha) }\end{array}$ & $\begin{array}{c}\text { Total de } \\
\text { área } \\
\text { sobrepo } \\
\text { sição } \\
\text { CAR } \\
\text { (ha) }\end{array}$ & $\begin{array}{c}\text { Oferta } \\
\text { Potencial } \\
\text { CAR sem } \\
\text { sobreposiçã } \\
\text { o (ha) }\end{array}$ & $\begin{array}{l}\text { (\%) Oferta } \\
\text { Potencial } \\
\text { CAR sem } \\
\text { sobreposiçãa } \\
\text { o (ha) }\end{array}$ & $\begin{array}{c}\text { SIGEF } \\
\text { Particula } \\
\text { r(ha) }\end{array}$ & $\begin{array}{l}\text { SIGEF } \\
\text { Público } \\
\text { (ha) }\end{array}$ & $\begin{array}{c}\text { SIGEF } \\
\text { Total } \\
\text { (ha) }\end{array}$ & $\begin{array}{c}\text { SIGEF } \\
\text { Público/ } \\
\text { Particula } \\
\mathbf{r} \text { (ha) }\end{array}$ & $\begin{array}{l}\text { SIGEF/A } \\
\text { ssentam } \\
\text { ento (ha) }\end{array}$ & $\begin{array}{l}\text { SIGEF/T } \\
\text { erra } \\
\text { Indígena } \\
\text { (ha) }\end{array}$ & $\begin{array}{c}\text { Total de } \\
\text { áreas } \\
\text { sobrepo } \\
\text { sição } \\
\text { SIGEF } \\
\text { Total } \\
\text { (ha) }\end{array}$ & $\begin{array}{c}\text { SIGEF } \\
\text { Total } \\
\text { sem área } \\
\text { sobrepo } \\
\text { sta (ha) }\end{array}$ & $\begin{array}{l}\text { Oferta } \\
\text { Atual } \\
\text { SIGEF } \\
\text { Particula } \\
\text { r sem } \\
\text { sobrepo } \\
\text { sições } \\
\text { (ha) }\end{array}$ & $\begin{array}{c}\%) \\
\text { Oferta } \\
\text { Atual } \\
\text { SIGEF } \\
\text { Particula } \\
\text { r sem } \\
\text { sobrepo } \\
\text { siçôes }\end{array}$ & $\begin{array}{c}\text { Assenta } \\
\text { mento } \\
\text { (ha) }\end{array}$ & $\begin{array}{c}\text { Terra } \\
\text { Indígena } \\
\text { (ha) }\end{array}$ & $\begin{array}{l}\text { Área } \\
\text { sem } \\
\text { cadastro } \\
\text { na UC } \\
\text { (ha) }\end{array}$ & $\begin{array}{c}\text { (\%)Área } \\
\text { sem } \\
\text { cadastro } \\
\text { na UC } \\
\text { (ha) }\end{array}$ \\
\hline $\begin{array}{l}\text { FLONA de } \\
\text { Cristópolis }\end{array}$ & BA & $12.840,59$ & 43,85 & $10.945,86$ & 85,24 & 4,68 & 0,00 & 0,00 & 4,68 & $10.941,18$ & 85,21 & 180,83 & 0,00 & 180,83 & 0,00 & 0,00 & 0,00 & 0,00 & 180,83 & 180,83 & 1,41 & 0,00 & 0,00 & $1.718,59$ & 13,38 \\
\hline $\begin{array}{c}\text { FLONAde Capão } \\
\text { Bonito* @ } \\
\end{array}$ & SP & $4.236,86$ & 14,47 & $1.219,73$ & 28,79 & 3,82 & 0,00 & 0,00 & 3,82 & $1.215,91$ & 28,70 & 26,74 & 0,00 & 26,74 & 0,00 & 0,00 & 0,00 & 0,00 & 26,74 & 26,74 & 0,63 & 0,00 & 0,00 & $2.994,21$ & 70,67 \\
\hline $\begin{array}{c}\text { FLONAde Silvânia } \\
* @ \\
\end{array}$ & GO & ,37 & 1,66 & 20,46 & 4,21 & 56 & 0,00 & 0,00 & 1,56 & 18,90 & 3,89 & 1,56 & 0,00 & 1,56 & 0,00 & 0,00 & 0,00 & 0,00 & 1,56 & 1,56 & 0,32 & 0,00 & 0,00 & 465,91 & 95,79 \\
\hline $\begin{array}{l}\text { FLONA da Mata } \\
\text { Grande \& }\end{array}$ & GO & $2.009,74$ & 6,86 & $2.009,74$ & 100,00 & 4,95 & $2.009,74$ & 0,00 & $2.014,69$ & 0,00 & 0,00 & 4,95 & 0,00 & 4,95 & 0,00 & 0,00 & 0,00 & 0,00 & 4,95 & 4,95 & 0,25 & $2.003,76$ & 0,00 & 1,03 & 0,05 \\
\hline FLONA de Brastia & $\mathrm{DF} / \mathrm{GO}$ & $9.336,17$ & 31,88 & $7.608,95$ & 81,50 & $3.444,52$ & 0,00 & 0,00 & $3.444,52$ & $4.164,43$ & 44,61 & 5,45 & $3.445,73$ & $3.451,17$ & 0,00 & 0,00 & 0,00 & 0,00 & $3.451,17$ & 5,45 & 0,06 & 0,00 & 0,00 & $1.720,57$ & 18,43 \\
\hline $\begin{array}{l}\text { FLONA de } \\
\text { Paraopeba }\end{array}$ & MG & 203,29 & 0,69 & 9,07 & 4,46 & 0,00 & 0,00 & 0,00 & 0,00 & 9,07 & 4,46 & 0,00 & 0,00 & 0,00 & 0,00 & 0,00 & 0,00 & 0,00 & 0,00 & 0,00 & 0,00 & 0,00 & 0,00 & 194,22 & 95,54 \\
\hline $\begin{array}{c}\text { FLONA dos } \\
\text { Palmares }\end{array}$ & PI & 168,21 & 0,57 & 0,00 & 0,00 & 0,00 & 0,00 & 0,00 & 0,00 & 0,00 & 0,00 & 0,00 & 0,00 & 0,00 & 0,00 & 0,00 & 0,00 & 0,00 & 0,00 & 0,00 & 0,00 & 0,00 & 0,00 & 168,21 & 100,00 \\
\hline TOTAL & & $29.281,23$ & 100,00 & $21.813,81$ & 74,50 & $3.459,53$ & $2.009,74$ & 0,00 & $5.469,27$ & \begin{tabular}{|l|}
$16.349,49$ \\
\end{tabular} & 55,84 & 219,52 & $3.445,73$ & $3.665,25$ & 0,00 & 0,00 & 0,00 & 0,00 & $3.665,25$ & 219,52 & 0,75 & $2.003,76$ & 0,00 & $7.262,73$ & 24,80 \\
\hline
\end{tabular}

Fonte: Sigef, CNUC e CAR (março de 2018).

Notas: * Situação fundiária - totalmente regularizada, conforme informações no CNUC.

** Situação fundiária - parcialmente regularizada, conforme informações no CNUC.

*** Situação fundiária - não regularizada, conforme informações no CNUC.

+ Possui plano de manejo.

\# A área da UC possui ocupações.

@ A área da UC não possui ocupações. 
Existe um desvio padrão elevado entre estes indicadores médios em relação à área de oferta potencial. Por exemplo, na Flona de Cristópolis, é de 10.941,18 ha, o que representa $85,21 \%$ de sua área total, que é de 12.840,59 ha. A oferta de áreas cadastradas como particulares e certificadas no Sigef é de apenas $1,41 \%$ de sua área. Como resultado da elevada área cadastrada no CAR sem sobreposições das demais áreas (oferta potencial), sua área sem cadastros é de $13,38 \%$.

A Flona de Brasília possui uma área total de 9.336,17 ha, destes, 7.608,95 ha estão cadastrados no CAR. Porém esta Flona possui uma área de 3.445,73 ha certificada no Sigef como pública, fazendo uma sobreposição de 3.444,52 ha com a área cadastrada no CAR, resultando numa área de oferta potencial para o mercado de compensação de RL de 4.164,43 ha, o que representa $44,61 \%$ de sua área total. Sua área sem cadastros é de $18,43 \%$.

A Flona da Mata Grande possui uma área total de 2.009,74 ha, 100\% de sua área está cadastrada no CAR e também é uma área de assentamento. Existe somente uma área de 4,95 ha certificada no Sigef como área particular que se sobrepõe ao CAR. Assim, sua área sem cadastros é inexistente $(0,05 \%)$.

A Flona Capão Bonito possui 4.236,86 ha, sendo que, desta área, 28,70\% representam área de oferta potencial para o mercado de compensação de RL (área do CAR sem sobreposições com outras áreas) e 180,83 ha são de área certificada como particular no Sigef sem sobreposição com as demais áreas, representando somente $1,41 \%$ de seu território. $\mathrm{O}$ percentual de área sem cadastros nesta UC é de 70,67\%. Esta Flona está totalmente regularizada e não possui ocupações, de acordo com os dados do CNUC.

A Flona dos Palmares, com uma área de apenas 168,21 ha, não possui áreas cadastradas nem no Sigef, nem no CAR. Não possui área de assentamento e terra indígena, o que justifica os $100 \%$ de sua área sem cadastro.

As Flonas de Silvânia e Paraopeba, com áreas totais de 486,37 ha e 203,29 ha respectivamente, possuem 95,79\% e 95,54\% de áreas sem cadastros. As áreas cadastradas no CAR sem sobreposição com as demais áreas (oferta potencial) são, respectivamente, de 18,90 ha e 9,07 ha. Somente a Flona de Silvânia possui uma área de 1,56 ha certificada como particular no Sigef, cerca de $0,32 \%$ de sua área total. Esta Flona está totalmente regularizada e não possui ocupações, de acordo com os dados do CNUC.

Visto que somente $0,75 \%$ do território das Flonas do Cerrado possui uma área total de 219,52 ha certificada no Sigef como área particular, a regularização fundiária destas UCs por meio do mercado de compensação de RL por doação de área de UC de domínio público é bastante limitada. 
A consolidação territorial das Flonas do Cerrado dependerá de uma ação discriminatória destas terras e de seus registros no Cartório de Registro de Imóveis como terras públicas e em nome do órgão gestor destas UCs, visto que somente 7.262,73 ha estão sem cadastros no CAR e no Sigef, sem as sobreposições de áreas.

\subsubsection{Ofertas atual e potencial de áreas para ingressarem no mercado de compensação de RL por doação de área de UC de domínio público: uma análise das reservas biológicas (Rebios) do bioma Cerrado e suas áreas sem cadastros}

As Rebios no bioma Cerrado somam 7 UCs de domínio público, sendo que todas são federais. Possuem uma área de 14.546,39 ha, representando apenas 0,30 \% do total da área das UCs de domínio público do Cerrado. Estas Rebios não possuem área de assentamentos e nem terras indígenas. Suas áreas certificadas no Sigef como particulares cadastradas sem sobreposição com as demais áreas estão na ordem de 32,62 ha. Esta é a oferta atual para o mercado de compensação de RL por doação. Esta área representa somente 0,22\% de seu território.

Somente a Rebio do Rio Descoberto possui uma área de 32,46 ha certificada no Sigef como particular, o que representa 7,48\% de sua área total. A Rebio de Culuene possui este indicador na ordem de $0,92 \%$. As demais Rebios não possuem áreas certificadas como particulares no Sigef.

De acordo com as informações do CNUC, nenhuma Rebio está regularizada. As Rebios da Contagem, do Guará e do Gama possuem ocupações. Somente a Rebio do Rio Descoberto possui plano de manejo. A tabela a seguir traz estas informações. 
Tabela 23 - Ofertas atual e potencial e áreas sem cadastro das reservas biológicas (Rebios) do bioma Cerrado em hectares (dados de março de 2018)

\begin{tabular}{|c|c|c|c|c|c|c|c|c|c|c|c|c|c|c|c|c|c|c|c|c|c|c|c|c|c|}
\hline $\begin{array}{c}\text { Nome das } \\
\text { Reservas } \\
\text { Biológicas } \\
\text { (REBIO) }\end{array}$ & $\mathbf{U F}$ & $\begin{array}{c}\text { Área UC } \\
\text { (ha) }\end{array}$ & $\begin{array}{l}(\%) \text { da } \\
\text { UC na } \\
\text { Àrea } \\
\text { Total } \\
\text { UCs }\end{array}$ & CAR (ha) & $\begin{array}{l}(\%) \\
\text { CAR } \\
\text { (ha) }\end{array}$ & $\begin{array}{c}\text { CAR/SI } \\
\text { GEF (ha) }\end{array}$ & $\begin{array}{l}\text { CAR/As } \\
\text { sentame } \\
\text { nto (ha) }\end{array}$ & $\begin{array}{l}\mathrm{CAR} / \mathrm{Te} \\
\text { rra } \\
\text { Indígena } \\
\text { (ha) }\end{array}$ & $\begin{array}{c}\text { Total de } \\
\text { área } \\
\text { sobrepo } \\
\text { sição } \\
\text { CAR } \\
\text { (ha) }\end{array}$ & $\begin{array}{c}\text { Oferta } \\
\text { Potencia } \\
\text { I CAR } \\
\text { sem } \\
\text { sobrepo } \\
\text { sição } \\
\text { (ha) }\end{array}$ & $\begin{array}{c}(\%) \\
\text { Oferta } \\
\text { Potencia } \\
\text { I CAR } \\
\text { sem } \\
\text { sobrepo } \\
\text { sição } \\
\text { (ha) }\end{array}$ & $\begin{array}{c}\text { SIGEF } \\
\text { Particula } \\
\mathbf{r} \text { (ha) }\end{array}$ & $\begin{array}{l}\text { SIGEF } \\
\text { Público } \\
\text { (ha) }\end{array}$ & $\begin{array}{c}\text { SIGEF } \\
\text { Total } \\
\text { (ha) }\end{array}$ & $\begin{array}{c}\text { SIGEF } \\
\text { Público/ } \\
\text { Particula } \\
\mathbf{r} \text { (ha) }\end{array}$ & $\begin{array}{l}\text { SIGEF/A } \\
\text { ssentam } \\
\text { ento (ha) }\end{array}$ & $\begin{array}{l}\text { SIGEF/T } \\
\text { erra } \\
\text { Indígena } \\
\text { (ha) }\end{array}$ & $\begin{array}{c}\text { Total de } \\
\text { áreas } \\
\text { sobrepo } \\
\text { sição } \\
\text { SIGEF } \\
\text { Total } \\
\text { (ha) }\end{array}$ & $\begin{array}{c}\text { SIGEF } \\
\text { Total } \\
\text { sem área } \\
\text { sobrepo } \\
\text { sta (ha) }\end{array}$ & $\begin{array}{c}\text { Oferta } \\
\text { Atual } \\
\text { SIGEF } \\
\text { Particula } \\
\text { r sem } \\
\text { sobrepo } \\
\text { sições } \\
\text { (ha) }\end{array}$ & $\begin{array}{c}(\%) \\
\text { Oferta } \\
\text { Atual } \\
\text { SIGEF } \\
\text { Particula } \\
\text { r sem } \\
\text { sobrepo } \\
\text { sições } \\
\text { na área } \\
\text { da UC } \\
\end{array}$ & $\begin{array}{l}\text { Assenta } \\
\text { mento } \\
\text { (ha) }\end{array}$ & $\begin{array}{c}\text { Terra } \\
\text { Indigena } \\
\text { (ha) }\end{array}$ & $\begin{array}{c}\text { Área } \\
\text { sem } \\
\text { cadastro } \\
\text { na UC } \\
\text { (ha) }\end{array}$ & $\begin{array}{c}\text { (\%)Área } \\
\text { sem } \\
\text { cadastro } \\
\text { na UC } \\
\text { (ha) }\end{array}$ \\
\hline \begin{tabular}{|c} 
REBIO do \\
Rio \\
Descoberto +
\end{tabular} & $\mathrm{DF} / \mathrm{GO}$ & 434,08 & 2,98 & 281,99 & 64,96 & 24,91 & 0,00 & 0,00 & 24,91 & 257,08 & 59,22 & 32,46 & 0,00 & 32,46 & 0,00 & 0,00 & 0,00 & 0,00 & 32,46 & 32,46 & 7,48 & 0,00 & 0,00 & 144,55 & 33,30 \\
\hline $\begin{array}{c}\text { REBIO de } \\
\text { Culuene } \\
\end{array}$ & MT & $3.613,67$ & 24,84 & 33,29 & 0,92 & 0,00 & 0,00 & 0,00 & 0,00 & 33,29 & 0,92 & 0,13 & 0,00 & 0,13 & 0,00 & 0,00 & 0,00 & 0,00 & 0,13 & 0,13 & 0,00 & 0,00 & 0,00 & $3.580,25$ & 99,08 \\
\hline $\begin{array}{c}\text { REBIO da } \\
\text { Contagem } \\
* * * * \\
\end{array}$ & DF & $3.411,71$ & 23,45 & $2.075,05$ & 60,82 & 0,00 & 0,00 & 0,00 & 0,00 & $2.075,05$ & 60,82 & 0,03 & 0,00 & 0,03 & 0,00 & 0,00 & 0,00 & 0,00 & 0,03 & 0,03 & 0,00 & 0,00 & 0,00 & $1.336,63$ & 39,18 \\
\hline $\begin{array}{l}\text { REBIO do } \\
\text { Cerradão }\end{array}$ & DF & 53,92 & 0,37 & 53,92 & 100,00 & 0,00 & 0,00 & 0,00 & 0,00 & 53,92 & 100,00 & 0,00 & 0,00 & 0,00 & 0,00 & 0,00 & 0,00 & 0,00 & 0,00 & 0,00 & 0,00 & 0,00 & 0,00 & 0,00 & 0,00 \\
\hline $\begin{array}{c}\text { REBIO do } \\
\text { Jaibá }\end{array}$ & MG & $6.350,89$ & 43,66 & 0,00 & 0,00 & 0,00 & 0,00 & 0,00 & 0,00 & 0,00 & 0,00 & 0,00 & 0,00 & 0,00 & 0,00 & 0,00 & 0,00 & 0,00 & 0,00 & 0,00 & 0,00 & 0,00 & 0,00 & $6.350,89$ & 100,00 \\
\hline $\begin{array}{l}\text { REBIO do } \\
\text { Guará**\# }\end{array}$ & DF & 145,37 & 1,00 & 145,37 & 100,00 & 0,00 & 0,00 & 0,00 & 0,00 & 145,37 & 100,00 & 0,00 & 0,00 & 0,00 & 0,00 & 0,00 & 0,00 & 0,00 & 0,00 & 0,00 & 0,00 & 0,00 & 0,00 & 0,00 & 0,00 \\
\hline $\begin{array}{l}\text { REBIO do } \\
\text { Gama**\#\# }\end{array}$ & DF & 536,75 & 3,69 & 536,75 & 100,00 & 0,00 & 0,00 & 0,00 & 0,00 & 536,75 & 100,00 & 0,00 & 0,00 & 0,00 & 0,00 & 0,00 & 0,00 & 0,00 & 0,00 & 0,00 & 0,00 & 0,00 & 0,00 & 0,00 & 0,00 \\
\hline TOTAL & & $14.546,39$ & 100,00 & $3.126,36^{\prime}$ & 21,49 & 24,91 & 0,00 & 0,00 & 24,91 & $3.101,45$ & 21,32 & 32,62 & 0,00 & 32,62 & 0,00 & 0,00 & 0,00 & 0,00 & 32,62 & 32,62 & 0,22 & 0,00 & 0,00 & $11.412,31$ & 78,45 \\
\hline
\end{tabular}

Fonte: Sigef, CNUC e CAR (março de 2018).

Notas: * Situação fundiária - totalmente regularizada, conforme informações no CNUC.

** Situação fundiária - parcialmente regularizada, conforme informações no CNUC.

*** Situação fundiária - não regularizada, conforme informações no CNUC.

+ Possui plano de manejo.

\# A área da UC possui ocupações.

@ A área da UC não possui ocupações. 
A oferta potencial, ou seja, a área do CAR sem sobreposição das demais áreas, nas Rebios do Cerrado soma 3.101,45 ha. As Rebios do Cerradão, do Guará e do Gama possuem $100 \%$ de suas áreas como oferta potencial. Dessa forma, nestas UCs a área sem cadastros é inexistente.

As Rebios do Rio Descoberto e da Contagem possuem, respectivamente, uma área de $59,22 \%$ e $60,82 \%$ de sua área total cadastrada no CAR, sem sobreposições das demais áreas (oferta potencial). As áreas sem cadastros destas Rebios representam, respectivamente, 33,30\% e $39,18 \%$ de sua área total.

A Rebio de Culuene possui 0,92\% de sua área cadastrada no CAR sem as sobreposições com as demais áreas. Como esta Rebio não possui áreas cadastradas no Sigef particular, sua porcentagem de áreas sem cadastros é de 99,08\%.

Como a oferta atual de áreas particulares certificadas no Sigef das Rebios é quase inexistente, pois somente a Rebio do Rio Descoberto possui área particular certificada no Sigef, o mercado de compensação de RL por doação de área de UC de domínio público será limitado para promover a regularização destas Rebios. A consolidação territorial destas UCs ocorrerá mediante uma ação de discriminação de terras.

\subsection{As UCs de domínio público do Cerrado: análise dos indicadores totais e seus percentuais das ofertas atuais e potenciais de terras para o mercado de compensação de RL por doação de área de UC e das áreas sem cadastros destas UCs}

A análise dos valores totais das ofertas atuais de terras das UCs de domínio público do Cerrado que serão transacionadas no mercado de compensação de RL por doação de área de UC, que são as áreas de particulares certificadas no Sigef pelo Incra sem sobreposição com as demais áreas, revela que estas áreas respondem por 709.775,52 ha.

A oferta potencial, que são as áreas cadastradas no CAR sem as sobreposições com as áreas de outros domínios, representa uma quantidade pouco expressiva, na ordem de 891.007,53 ha, na medida em que parte destas áreas pode vir a não constituir propriedade, por serem terras públicas griladas por particulares.

A tabela a seguir traz estas informações. 
Tabela 24 - Dados médios das ofertas atual e potencial e das áreas sem cadastros nas UCs de domínio público

\begin{tabular}{|c|c|c|c|c|c|c|c|}
\hline $\begin{array}{c}\text { Unidades de } \\
\text { Conservação de } \\
\text { Domínio } \\
\text { Público Cerrado }\end{array}$ & Área Total (ha) & $\begin{array}{c}\text { Oferta Atual } \\
\text { SIGEF } \\
\text { Particular sem } \\
\text { sobreposições } \\
\text { (ha) }\end{array}$ & $\begin{array}{c}\text { (\%) Oferta Atual } \\
\text { SIGEF Particular } \\
\text { sem sobreposições } \\
\text { (ha) }\end{array}$ & $\begin{array}{c}\text { Oferta Potencial } \\
\text { CAR sem } \\
\text { sobreposição } \\
\text { (ha) }\end{array}$ & $\begin{array}{c}\text { (\%) Oferta } \\
\text { Potencial } \\
\text { CAR sem } \\
\text { sobreposição } \\
\text { (ha) }\end{array}$ & $\begin{array}{c}\text { Área sem } \\
\text { cadas tro nas } \\
\text { UCs (ha) }\end{array}$ & $\begin{array}{l}\text { (\%) Área } \\
\text { sem } \\
\text { cadastro } \\
\text { nas UCs } \\
\text { (ha) } *\end{array}$ \\
\hline $\begin{array}{c}\text { Parques } \\
\text { Nacionais } \\
\end{array}$ & $3.594 .852,37$ & $435.980,60$ & 12,13 & $749.565,22$ & 20,85 & $1.827 .532,82$ & 50,84 \\
\hline $\begin{array}{c}\text { Estações } \\
\text { Ecológicas }\end{array}$ & $1.137 .190,64$ & $252.723,20$ & 22,22 & $92.232,82$ & 8,11 & 536150,2661 & 47,15 \\
\hline $\begin{array}{c}\text { Reservas } \\
\text { Extrativistas }\end{array}$ & $89.024,69$ & 20819,55955 & 23,39 & $29.758,55$ & 33,43 & $28.136,79$ & 31,61 \\
\hline $\begin{array}{l}\text { Florestas } \\
\text { Nacionais }\end{array}$ & 29281,23 & 219,52 & 0,75 & $16.349,49$ & 55,84 & $7.262,73$ & 24,80 \\
\hline $\begin{array}{c}\text { Reservas } \\
\text { Biológicas }\end{array}$ & 14546,39 & 32,62 & 0,22 & 3101,452719 & 21,32 & 11412,31289 & 78,45 \\
\hline TOTAL & 4.864.895,32 & 709.775,52 & 14,59 & 891.007,53 & 18,32 & $2.410 .494,92$ & 49,55 \\
\hline
\end{tabular}

Fonte: Sigef e CAR.

Notas: * Nas áreas sem cadastros, foram descontadas as terras indígenas e os assentamentos das áreas das UCs.

Diante da área total das UCs de domínio público, que é de 4.864.895,32 ha, o percentual de apenas $14,59 \%$ desta área que atualmente pode ingressar como oferta de terras para o mercado de compensação de RL mostra-se bastante limitado como forma de regularização fundiária destas UCs, para que alcancem sua consolidação territorial. No entanto, considerando o preço mínimo das terras no Cerrado, que é de R 1.500 o hectare - segundo informações de Saretta (2017, p. 96) e dados da Tabela 10 com informações do ICMBio -, o Estado brasileiro não seria onerado com desapropriações de terras num valor de $\mathrm{R} \$ 1.064 .662 .500$, para a área de oferta atual de 709.775 ha, conforme a Tabela 24. Vale considerar que os preços utilizados são de mercados de áreas produtivas, maiores do que os preços das áreas inseridas nos limites das UCs de domínio público, que possuem um custo de oportunidade mais baixo em relação a áreas comercializadas no mercado de terras, dadas as restrições ambientais.

Este montante de recursos é consideravelmente maior do que o valor pago pelas compensações ambientais, que foi de $\mathrm{R} \$ 162.763 .218$, gastos com as desapropriações de terras para a regularização fundiária das UCs nos anos de 2009 a 2011 (vide Tabela 12) (TCU, 2013).

Os valores encontrados, por meio da metodologia deste trabalho, de oferta atual de áreas (709.775, 52 ha) somado com a oferta potencial de áreas (891.997,53 ha) é de 1.601.773,05 ha e se aproxima da estimativa do montante de áreas particulares encontrado pelo ICMBio, de 1.676.925 ha no bioma Cerrado (dados das Tabelas 10 e 11).

Este montante de áreas de 1.601.773,05 ha (atual e potencial) que pode ser ofertado para o mercado de compensação de RL por doação de áreas de UC de domínio público é menor do 
que a demanda de déficit de RL de 4,2 milhões ha - vide Tabela 16, dados de Guidotti et al. (2017).

Em termos de vegetação nativa desprotegida, ou seja, excedente às exigências de APP e RL, em áreas rurais privadas, nota-se que esta é cinco vezes maior que o déficit em RLs e APPs. No caso específico do Cerrado, por exemplo, a vegetação nativa desprotegida excede em sete vezes o déficit em RLs e APPs, perfazendo um total de área de 44 milhões ha - enquanto o déficit de RL é de 4,2 milhões ha e o déficit de APPs é de 1,9 milhões ha (GUIDOTTI et al., 2017, p. 5). Portanto este déficit de RL deverá ser suprido não somente pelas áreas pendentes de regularização fundiária inseridas nos limites das UCs de domínio público, mas também pelas demais formas de compensação de RL discutidas no capítulo 3 deste trabalho, que poderá utilizar esta área desprotegida por lei para ser ofertada no mercado de compensação de RL.

Dessa forma, as terras particulares das UCs pendentes de regularização fundiária terão uma forte ${ }^{96}$ concorrência de um volume bastante considerável de terras disponíveis a partir de outros mecanismos do NCF para compensação de RL.

O alto percentual de áreas das UCs de domínio público do Cerrado não cadastradas até a data de março de 2018, que é de 49,55\%, é um indicador de que a consolidação territorial das UCs de domínio público do Cerrado irá depender mais da ação do Estado em promover um estudo fundiário nestes parques para regularizar estas áreas do que do mercado de compensação de RL por doação de área de UC de domínio público.

Rocha, Drummond e Ganem (2010) argumentam que a regularização fundiária é complexa e que contempla outros procedimentos alternativos à desapropriação, entendida como ações de aquisição de terras e pagamento por benfeitorias pelo poder público e o consequente registro dessas terras para o domínio do patrimônio público.

Segundo Rocha, Drummond e Ganem (2010, p. 220), existem procedimentos a serem adotados que são alternativas às desapropriações e são factíveis de serem executados sem que haja necessidade de criação de novas leis. Primeiramente, a pesquisa cartorial de títulos de terras públicas é um procedimento que pode favorecer a regularização fundiária de UCs, já que existem relatos de terras públicas abrangidas pelas UCs de domínio público que estão sob posse de terceiros. Vale lembrar que muitas destas terras estão com suas áreas cadastradas no CAR. Um segundo procedimento a adotar, igualmente dependente de pesquisa sistemática em

\footnotetext{
${ }^{96}$ Conforme mencionado no capítulo 3 deste trabalho, os outros mercados de compensação de RL preconizados no NCF ainda são incipientes devido à falta de regulamentação básica de certos de mecanismos, a exemplo do CRA. Soma-se a isto as dificuldades dos órgãos ambientais estaduais e federais em realizar a concretização e a operacionalização destes mercados, o que significa cadastrar, avaliar e impor termos de conduta e monitorá-los com os recursos financeiros e humanos que estas instituições dispõem atualmente.
} 
cartórios, é a identificação e incorporação de terras devolutas. Estas terras geralmente são de difícil identificação, principalmente em território de vastas áreas, mas podem ser identificadas por meio de levantamentos e estudos fundiários nas áreas das UCs.

O conhecimento das terras devolutas também auxilia nas ações de desapropriação de terras, onde estas terras foram griladas do patrimônio público por meio da obtenção de documentos fraudulentos, como também nas posses de áreas devolutas.

Segundo Rocha, Drummond e Ganem (2010, p. 221-222, grifos dos autores), também é necessário que se realize a

[...] pesquisa cartorial sobre títulos de terras particulares. Considerando a probabilidade (por vezes forte) de existirem documentos de propriedade particular juridicamente inconsistentes, é imprescindível que sejam verificados todos os títulos de terras sobrepostas e vizinhas aos PNs [leia-se parques nacionais, mas que se estende para as demais UCs de domínio público], por meio dos levantamentos das cadeias sucessórias e da averiguação do cumprimento dos princípios que regem a transmissão das propriedades, até a sua origem. Títulos dúbios ou suspeitos devem ser conferidos administrativamente e contestados judicialmente pelo órgão gestor de UCs, o que significa abrir toda uma outra linha de trabalho, complementar à pesquisa de terras públicas ou devolutas. Estes procedimentos tendem a ser demorados, mas podem contribuir significativamente para resolver pendências. Um terceiro procedimento capaz de ajudar na consolidação fundiária das UCs é que o órgão gestor desenvolva uma ação sistemática e decidida na localização e incorporação de terras abandonadas. Trata-se de terras sobre as quais o proprietário deixa de satisfazer os ônus fiscais, cessados os atos de posse (Lei n. 10 406, de 10 de janeiro de 2002, que institui o Novo Código Civil, art. 1 276). O imóvel é arrecadado como bem vago e, no prazo de três anos, passa à propriedade do Município ou do Distrito Federal, em caso de imóvel urbano, ou à propriedade da União, em caso de imóvel rural. Haverá casos em que tais terras sejam de interesse para as políticas de conservação e sejam eventualmente incorporadas a UCs, em geral, e a PNs, em particular.

Considerando os resultados expostos, argumenta-se que a oferta atual (709.775,52 ha) de terras para o mercado de compensação de RL por doação de área de UC de domínio público no Cerrado - como contribuição para a regularização fundiária de mudança de domínio de particulares para os órgãos gestores das UCs de domínio público deste bioma, o que, por consequência, levaria à sua consolidação territorial - é limitada.

As limitações ocorrem pela pouca oferta de áreas particulares existente com número de matrícula em relação ao território total das UCs de domínio público do Cerrado que estão cadastradas no Sigef.

As áreas cadastradas no CAR são um indicativo de áreas potenciais, pois não se sabe o quanto de áreas possuem condições jurídicas de tornar-se propriedade. Dessa forma, o CAR será um ótimo instrumento para dar início a um levantamento dos imóveis rurais (sejam posses 
ou propriedades privadas) que permita realizar as ações de regularização fundiária propostas por Rocha, Drummond e Ganem (2010).

Outra limitação para a consolidação territorial das UCs de domínio público do Cerrado é que quase $50 \%$ de seu território está sem cadastros, ou seja, pela ausência de cadastros destas terras, subentende-se que estas áreas sejam formadas por terras devolutas.

As limitações expostas anteriormente existem em consequência da fragilidade da governança de terras do Brasil, em especial da insegurança da propriedade brasileira, seja esta pública ou privada, que se reflete também no desconhecimento, por parte do Estado, de suas terras devolutas, possibilitando o processo de apossamento legalizado e de grilagem destas terras, ciclo este que se retroalimenta e causa ainda mais insegurança aos direitos de propriedade no Brasil.

A limitação da insegurança dos direitos de propriedades também é refletida nos sistemas de administração de terras, pois o Sicar não possui uma base fundiária compartilhada com o SNCR e o Sigef. As sobreposições de áreas de diversos domínios é um indicativo da limitação do sistema de cadastro brasileiro.

Dado o limitado alcance (1) da oferta atual de terras das UCs de domínio público do Cerrado (2) diante das áreas de posses e de propriedades autodeclaradas no CAR, que podem ser questionadas, e da (3) extensa área de terras não cadastradas nas UCs de domínio público do Cerrado, o mercado de compensação de RL por doação de área de UC de domínio público, como mecanismo de regularização fundiária destas terras, será limitado no processo de consolidação territorial das UCs de domínio público deste bioma.

Ao contrário do que muitos analistas públicos e privados argumentam, ao afirmarem que o mercado de compensação de RL por doação de área de UC de domínio público terá grande contribuição na regularização e consolidação fundiária destas UCs, esta contribuição é limitada, diante da pouca oferta de área disponível para este mercado, apesar do valor expressivo que o setor público deixaria de gastar com as indenizações de terras, aproximadamente $\mathrm{R} \$$ 1.064.662.500. Este montante de recursos financeiros é a quantidade em reais que seria transacionada no mercado de compensação de RL por doação de área de UCs de domínio público.

Dessa forma, a consolidação territorial das UCs de domínio público do Cerrado dependerá em grande medida de políticas do poder público que proponham e acompanhem as ações de regularização fundiária propostas por Rocha, Drummond e Ganem (2010), que normalmente são complexas e de longa duração. 


\section{CONCLUSÕES}

No Brasil, o SNUC, definido por meio da Lei $n^{\circ} 9.985$ de julho de 2000, e o NCF (Lei $n^{\circ}$ 12.651, de 2012) são legislações de extrema importância para a proteção de seus recursos naturais. Ambas legislações de proteção dos ecossistemas naturais estão alicerçadas em princípios que regem a Constituição Federal de 1988 relacionados ao meio ambiente ecologicamente equilibrado, por reconhecerem tanto as UCs como também todas as áreas que devem ser protegidas nos imóveis rurais (RL e APPs) do território brasileiro. Este reconhecimento é importante, porque assume o que determina o art. 225 da Constituição Federal: que o meio ambiente saudável é um direito de todos e cabe não apenas ao poder público, mas também a todos o dever de defendê-lo e preservá-lo, para as presentes e futuras gerações. Nesse contexto, as propriedades privadas devem cumprir sua função social, como afirma o art. $5^{\circ}$, incisos XXII e XXIII.

Com a promulgação do NCF, abriu-se a possibilidade de uma estreita relação entre as áreas privadas e sua função social por meio das RLs e UCs. Ou seja, estas fazem parte de um mesmo mecanismo que contribui para dois objetivos diferentes: a regularização ambiental da RL em propriedades privadas e a regularização fundiária das UCs de domínio público, visando à melhoria da preservação ambiental.

O NCF estabeleceu uma política ambiental que possui um verdadeiro policymix de instrumentos de políticas, de modo que os instrumentos de comando e controle atuam junto com os econômicos, tendo o CAR o seu mecanismo de comunicação e monitoramento. Porém, como exposto no capítulo 2 deste trabalho, se o direito de propriedade não estiver definido claramente, a política ambiental terá problemas para a sua operacionalização. Da mesma forma, o contexto institucional em que são formuladas estas políticas é de extrema importância para o sucesso destes instrumentos, já que os papéis regulador e policial dos governos precisam funcionar em associação para o cumprimento das normas estabelecidas.

Este é o ponto central da fragilidade do mecanismo de compensação de RL por doação de área de UC de domínio público instituída pelo NCF, ou seja, a ausência de (ou dificuldade de assinalar) direitos garantidos e assegurados de propriedade sobre a terra. Em outras palavras, a insegurança da propriedade da terra, fato este que constitui uma precondição básica para o funcionamento dos mercados de terras, é ponto central da fragilidade do mecanismo de compensação de RL analisado e que é decorrente da debilidade da governança de terras do Brasil. 
No Brasil, a governança de terras, historicamente, criou um sistema de administração de terras em que existe a fragilidade entre os registros de propriedade e os sistemas de cadastro. Na dinâmica nacional de aquisição de terras, coexistem dois tipos de direitos: o direito de posse e o direito de propriedade, que têm efeitos diferentes e ambos são aceitos pelos sistemas de cadastros brasileiros, sem informação gráfica que delimite fisicamente a área.

As inconsistências da governança de terras no Brasil são, em grande parte, advindas dessa fragilidade e possibilitam que imóveis de posseiros e de proprietários sejam cadastrados mediante um número somente, com a informação literal descritiva, ou seja, sem informação gráfica que delimite fisicamente a área e sem a comprovação do registro de propriedade. Esta fragilidade entre os sistemas de cadastros e de registros repercute em diversas fraudes existentes no mercado de terras e impede que as políticas públicas que necessitem de uma base fundiária sejam eficientes e eficazes (BUENO; REYDON; SIQUEIRA, 2017).

Decorrente desta fragilidade, pode-se resumir as principais características da débil governança de terras do Brasil, que são: existência de extensas áreas de terras com indefinição de direitos de propriedade, limitações dos cartórios, ausência de um cadastro oficial e integrado de terras públicas e privadas, baixos níveis de tributação sobre imóveis e governança negligente na aquisição de terras e florestas. Na ausência de um cadastro integrado de terras públicas e privadas, os principais órgãos responsáveis pela gestão destas terras não dispõem de um cadastro integrado com definições jurídicas diferentes. Assim, os órgãos federais e estaduais encarregados da gestão das terras públicas e privadas estão, em grande parte, operando sem um inventário de imóveis adequado, que seria um elemento fundamental para a gestão das políticas, como é o caso do CAR.

Nesse contexto, a realidade da situação fundiária do Brasil ainda carece de um adequado equacionamento, caracterizada por inúmeras situações, por exemplo: terras de domínio do Estado ocupadas ou não por posseiros ou intrusos; terras de particulares, muitas vezes de domínio indefinido ou contestável, exploradas ou não; terras de particulares ou posseiros ocupadas pelas áreas de UCs; terras devolutas ou "terras de ninguém" ocupadas por posseiros com títulos de propriedade falso. Nesse mosaico fundiário, ainda se somam os terrenos de marinha e/ou acrescidos, ilhas, terrenos marginais, várzeas, mar territorial, entre outros (ROCHA; DRUMMOND; GANEM, 2010). Cada tipo de terra destinada para cada função é gerida por diversos órgãos federativos, tais como: SPU, Incra, Ibama, Funai, ICMBio e demais instituições das unidades federativas do Brasil.

As áreas decretadas como UCs fazem parte do mosaico fundiário descrito anteriormente. Dessa forma, a presente tese atingiu seu objetivo de mensurar 
metodologicamente as quantidades de ofertas atual e potencial para serem transacionadas no mercado de compensação de RL por doação de área de UCs de domínio público e confirmou sua hipótese inicial: diante da debilidade da governança de terras brasileira, a contribuição deste mercado de terras para a consolidação territorial destas UCs será limitado devido à baixa oferta de áreas disponíveis para este mercado (somente 14,59\% da área total das UCs) e à existência de áreas cadastradas no CAR que podem não constituir propriedades privadas (18,32\% da área total das UCs analisadas).

Em contrapartida, a metodologia elaborada e discutida nesta tese possibilitou aferir o montante de recursos financeiros, cerca de $\mathrm{R} \$ 1.064 .662 .500,00$, que este mercado transacionará, sem ônus financeiros ao Estado, para a efetivação da regularização fundiária das UCs de domínio público do Cerrado, auxiliando na política de consolidação territorial destas UCs. Apesar da pouca área de oferta atual apta para ser transacionada, o montante de recursos financeiros transacionado neste mercado de terras é relevante. Dessa forma, em termos econômicos, esta política pode ser considerada uma grande inovação do NCF.

Vale ressaltar, conforme discutido no capítulo 3 deste trabalho, que as leis e procedimentos que regulamentarão o mercado de compensação de RL por doação de área de UCs serão estabelecidos de acordo com a política de cada estado da federação brasileira. Este é um fator relevante a se considerar para a efetivação da criação deste mercado de terras estabelecido no NCF, que auxiliará no processo de consolidação territorial das UCs de domínio público.

Em suma, a despeito da debilidade da governança de terras no Brasil, a contribuição da consolidação territorial de UCs, com base na criação de um mercado de terras, como instrumento definido pelo NCF, pode ser um mecanismo, mesmo que pouco expressivo, ainda assim relevante para a conservação ambiental. 


\section{REFERÊNCIAS}

ANDRADE, Daniel C.; BORGES, Lucas M. de C. A utilização de policy mix em arranjos de política ambiental: notas preliminares. In: ENCONTRO NACIONAL DA ECOECO, IX, 2011, Brasília. Anais... Uberlândia: ECOECO, 2011. Não paginado.

ANDRADE, Henrique V. de. A Desoneração de Reserva Legal como instrumento de consolidação territorial de unidades de conservação [slides]. ICMBio-SEDE, 2011. Disponível em: <http://www.agu.gov.br/page/download/index/id/10718326>. Acesso em: 15 set. 2018.

ARAÚJO, Elis; BARRETO, Paulo. Estratégias e fontes de recursos para proteger as Unidades de Conservação da Amazônia. Belém: Imazon, 2015. Disponível em: $<$ http://imazon.org.br/estrategias-e-fontes-de-re- cursos-para-proteger-as-unidades-deconservacao-da-amazonia/>. Acesso em: 15 set. 2018.

ARAÚJO, Elis et al. Unidades de conservação mais desmatadas da Amazônia Legal 20122015. Belém: Imazon, 2017.

BENATTI, José et al. Questão fundiária e sucessão da terra na fronteira Oeste da Amazônia. Novos Cadernos NAEA, v. 11, n. 2, p. 85-122, dez. 2008. Disponível em: $<$ http://www.periodicos.ufpa.br/index.php/ncn/article/view/273/436>. Acesso em: 15 set. 2018.

BERNARDO, Karina T. Análise do êxito dos sistemas estaduais de gestão de reservas legais com foco no mecanismo de compensação. 2010. 120 p. Dissertação (Mestrado em Ciências da Engenharia Ambiental)-Escola de Engenharia de São Carlos, Universidade de São Paulo, São Carlos, 2010.

BERNASCONI, Paula. Custo-efetividade ecológica da compensação de Reserva Legal entre propriedades no estado de São Paulo. 2013. 96 p. Dissertação (Mestrado em Desenvolvimento Econômico)-Instituto de Economia da Universidade de Campinas (Unicamp), Campinas, São Paulo, 2013.

BOURLAG, Norman. Feeding a World of 10 Billion People: The Miracle Ahead. In Vitro Cellular \& Developmental Biology - Plant, v. 38, n. 2, p. 221-228, 2002.

BRANNSTROM, Christian et al. Land change in the Brazilian Savanna (Cerrado), 19862002: Comparative analysis and implications for land-use policy. Land Use Policy, v. 25, n. 4, p. 579-595, 2007.

BRASIL. Constituição da República Federativa do Brasil de 1988 [online]. Brasília, 1988. Disponível em: <http://www.planalto.gov.br/ccivil_03/constituicao/constituicao.htm>. Acesso em: 28 set. 2018.

Lei $\mathbf{n}^{\circ}$ 9.985, de 18 de julho de 2000. Regulamenta o art. 225, $\S 1^{\circ}$, incisos I, II, III e VII da Constituição Federal, institui o Sistema Nacional de Unidades de Conservação da Natureza e dá outras providências. Disponível em: <http://www.planalto.gov.br/ccivil_03/LEIS/L9985.htm>. Acesso em: 15 set. 2018. 
BRASIL. Lei no 12.651, de 25 de maio de 2012. Dispõe sobre a proteção da vegetação nativa; altera as Leis $\mathrm{n}^{\circ} 6.938$, de 31 de agosto de 1981, 9.393, de 19 de dezembro de 1996, e 11.428, de 22 de dezembro de 2006; revoga as Leis $n^{\circ} 4.771$, de 15 de setembro de 1965, e 7.754, de 14 de abril de 1989, e a Medida Provisória n 2.166-67, de 24 de agosto de 2001; e dá outras providências. Disponível em: <http://www.planalto.gov.br/ccivil_03/_ato20112014/2012/lei/112651.htm>. Acesso em: 15 set. 2018.

Ministério Público Federal - MPF. Regularização fundiária em unidades de conservação. Brasília: MPF, 2014. (Série Manuais de Atuação,1).

BRÜSEKE, Franz. A crítica da técnica moderna. Estudos Sociedade e Agricultura, Rio de Janeiro: UFRRJ, n. 10, p. 5-55, abr. 1998.

BUENO, Ana P. S.; REYDON, Bastiaan P. Indefinição jurídica da propriedade: aspectos legais associados à propriedade da terra. In: REYDON, Bastiaan P. et al. (Ed.). Governança de terras: da teoria à realidade brasileira. Brasília: FAO/SEAD, 2017. p. 65-101.

CAMPOS, Ana L. G. Instrumentos para conservação das reservas florestais e demais formas de vegetação localizadas nas propriedades privadas. 2017. 265 p. Tese (Doutorado em Direito Econômico e Financeiro)-Faculdade de Direito, Universidade de São Paulo, São Paulo, 2017.

CARNEIRO, Andrea; ERBA, Diego; AUGUSTO, Eduardo. Cadastro Multifinalitário 3D: Conceitos e Perspectivas de implantação no Brasil. Revista Brasileira de Cartografia, n. 64/2, p. 257-271, 2012.

CARVALHO, Francisco de S. V. de. Processo discriminatório de terras: o caso do Pontal do Paranapanema (SP). 2004. 65 p. Dissertação (Mestrado em Engenharia Civil)Universidade Federal de Santa Catarina, Florianópolis, 2004.

CARVALHO, Lucas de A. O novo Código Florestal comentado, artigo por artigo. 2. ed. Curitiba: Juruá, 2016.

CASES, Maria O. Noções Básicas Para Elaboração de Planos de Manejo. In: (Org.).

Gestão de Unidades de Conservação. Brasília: WWF \& IPÊ, 2012. p. 76-115.

CHAVES, Thais S. Regularização Fundiária em Unidades de conservação do Rio Grande do Sul. 2014. 30 p. Monografia (Bacharelado em Ciências Biológicas)-Universidade Federal do Rio Grande de Sul (UFRS), Porto Alegre, 2014.

CHEADE, Mariana F. et al. Compensação de Reserva Legal: mecanismo para regularização fundiária das Unidades de Conservação. In: MENEZES, Gilceli A. et al. Práticas Inovadoras na Gestão de áreas Protegidas. Gestores Empreendedores: Inovação na Gestão de Unidades de Conservação. Brasil: Instituto de Pesquisas Ecológicas (IPÊ); Instituto Chico Mendes de Conservação da Biodiversidade (ICMBio), 2014. p. 88-90. Disponível em:

<http://www.icmbio.gov.br/praticasinovadoras/images/stories/publicacoes/2014/publicacao_p raticas_2014a.pdf >. Acesso em: 15 set. 2018. 
CHIAVARI, Joana et al. Panorama dos Direitos de Propriedade no Brasil Rural.

Legislação, Gestão Fundiária e Código Florestal. Rio de Janeiro: PUC-Rio, 2016. Disponível em: <https://climatepolicyinitiative.org/wp-

content/uploads/2016/11/Panorama_dos_direitos_de_propriedade_no_Brasil_rural_CPI.pdf > . Acesso em: 15 set. 2018.

CHIAVARI, Joana; LOPES, Cristina Leme. Os Caminhos para a Regularização Ambiental: decifrando o novo Código Florestal. In: SILVA, Ana P.; MARQUES, Henrique R.;

SAMBUICHI, Regina Helena (Orgs.). Mudanças no código florestal brasileiro: desafios para a implementação da nova lei. Rio de Janeiro: Ipea, 2016. p. 21-44.

Cota de Reserva Ambiental: melhor opção para compensar Reserva Legal? INPUT [site], jul. 2017. Disponível em: <http://www.inputbrasil.org/publicacoes/cota-de-reservaambiental-melhor-opcao-para-compensar-reserva-legal/>. Acesso em: 15 set. 2018.

CNUC/MMA. Tabela Consolidada das Unidades de Conservação. Atualizada em 10/07/2017. Disponível em:

<http://www.mma.gov.br/images/arquivo/80112/CNUC_JUL17\%20-\%20B_Cat.pdf>. Acesso em: 7 nov. 2017.

COSTA, Rita Damasceno. Insegurança dos direitos de propriedade no Brasil:

Consequências e obstáculos para superação [relatório]. Rio de Janeiro: Climate Policy Initiative; PUC-Rio, ago. 2016.

COSTA NETO, Joaquim de Britto. A complexidade da questão fundiária nos parques e estações ecológicas do estado de São Paulo: origens e efeitos da indisciplina da documentação e do registro imobiliário. São Paulo: Instituto Florestal, 2018.

CRAVEIRO, Juliana Rodrigues Venturi. Caracterização das Unidades de Conservação: Referências sobre o Sistema Nacional de Unidades de Conservação da Natureza. In: ENCONTRO DE GEÓGRAFOS DA AMÉRICA LATINA (EGAL), 12., 2009, Montevidéu. Anais... Equador: Asociación Geográfica del Ecuador, 2009. p. 1-13.

CUNHA, Paulo R. O Código Florestal e os processos de formulação do mecanismo de compensação de Reserva Legal (1996-2012): ambiente político e política ambiental.

Dissertação (Mestrado em Ciência Ambiental)-Universidade de São Paulo, São Paulo, 2013.

DALY, Herman E.; FARLEY, Joshua. Ecological Economics: principles and applications. 2. ed. Washington: Island Press, 2010.

DAMASCENO, Rita; CHIAVARI, Joana; LOPES, Cristina Leme. Direitos de propriedade no Brasil rural: história, problemas e caminhos. Rio de Janeiro: Omidyar Network; Climate Policy Initiative, abr. 2017.

DRUMMOND, José Augusto; FRANCO, José Luiz de Andrade; OLIVEIRA, Daniela de. Uma análise sobre a história e a situação das unidades de conservação no Brasil. In: GANEM, Roseli Senna (Org.). Conservação da biodiversidade: legislação e políticas públicas. Brasília: Edições Câmara, 2010. p. 341-385. (Série memória e análise de leis, n. 2). Disponível em: <http://bd.camara.gov.br/bd/handle/bdcamara/5444>. Acesso em: 15 set. 2018. 
FAO - FOOD AND AGRICULTURE ORGANIZATION OF THE UNITED NATIONS. Buena gobernanza en la tenencia y la administración de tierras. Roma, 2007. (Estudios sobre tenencia de la tierra, 9).

Diretrizes voluntárias sobre a governança responsável da terra, dos recursos pesqueiros e florestais no contexto da segurança alimentar nacional. Brasília, 2015. Disponível em: <http://www.mda.gov.br/sitemda/sites/sitemda/files/user_img_19/Diretrizes web.pdf>. Acesso em: 15 set. 2018.

FERNANDES, Vitor B. Passado não resolvido: a histórica falta de regulação na ocupação de terras no Brasil e após 1964. 2014. 155 p. Dissertação (Mestrado em Desenvolvimento Econômico)-Universidade Estadual de Campinas, Campinas, 2014.

A relação entre a governança de terras e o desenvolvimento econômico: da teoria a uma revisão sistemática de resultados empíricos. 2018. 116 p. Tese (Doutorado em Desenvolvimento Econômico)-Instituto de Economia, Universidade Estadual de Campinas, Campinas, 2018.

FERNANDES, Vitor B.; REYDON, Bastiaan P. A governança de terras e o desenvolvimento econômico. In: REYDON, Bastiaan P. et al. (Ed.). Governança de terras: da teoria à realidade brasileira. Brasília: FAO/SEAD, 2017. p. 43-64.

FREITAS, Flávio L. M. de; SPAROVEK, Gerd; MATSUMOTO, Marcelo. A adicionalidade do mecanismo de compensação de reserva legal da Lei n ${ }^{\circ}$ 12.651/2012: uma análise da oferta e demanda de cotas de reserva ambiental. In: SILVA, Ana P. M.; MARQUES, Henrique R.; SAMBUICHI, Regina H. R. (Org.). Mudanças no Código Florestal brasileiro: desafios para a implementação da nova lei. Brasília: Ipea, 2016. p. 125-158.

FREITAS, Flávio L. M.; GUIDOTTI, Vinícius; SPAROVEK, Gerd. Nota técnica: Malha fundiária do Brasil, v.170321. Atlas - A Geografia da Agropecuária Brasileira [site], Imaflora, 2017. Disponível em: <www.imaflora.org/atlasagropecuario>. Acesso em: 15 set. 2018.

GARCIA, Elaine P. de A. et al. Diagnósticos, problemas e soluções. In: REYDON, Bastiaan et al. (Ed.). Governança de terras: da teoria à realidade brasileira. Brasília: FAO/SEAD, 2017. p. 231-249.

GODOY, Larissa Ribeiro da Cruz; LEUZINGER, Márcia Dieguez. O financiamento do Sistema Nacional de Unidades de Conservação no Brasil: características e tendências. Revista de Informação Legislativa, ano 52, n. 206, p. 223-243, abr./jun. 2015. Disponível em: <https://www12.senado.leg.br/ril/edicoes/52/206/ril_v52_n206_p223.pdf>. Acesso em: 10 out. 2018.

GOEDERT, Wenceslau. Estratégias de manejo das savanas. In: SARMIENTO, Guillermo (Ed.). Las sabanas americanas: aspectos de su biogeografia, ecología y utilización. Venezuela: Acta Científica Venezolana, 1990. p. 191-218.

GUIDOTTI, Vinícius et al. Números detalhados do novo Código Florestal e suas implicações para o PRAs. Sustentabilidade em Debate, v. 5, p. 1-10, 2017. 
HOFFMAN, William A.; MOREIRA, Adriana G. The role of fire in population dynamics of woody plants. In: OLIVEIRA, Paulo S.; MARQUIS, Robert J. (Eds.). The Cerrados of Brazil: Ecology and Natural History of a Neotropical Savanna. Columbia University Press, 2002. p. 159-177.

IBGE. Mapa de Biomas do Brasil - primeira aproximação. Brasil, 2004. Disponível em: <ftp://ftp.ibge.gov.br/Cartas_e_Mapas/Mapas_Murais/>. Acesso em: 15 set. 2018.

ICMBIO - INSTITUTO CHICO MENDES DE CONSERVAÇÃO DA BIODIVERSIDADE. MINISTÉRIO DO MEIO AMBIENTE. Instrução Normativa no 2, de 3 de setembro de 2009. Brasília, 2009. Disponível em: <http://www.icmbio.gov.br/portal/images/stories/o-quesomos/in022009.pdf >. Acesso em: 15 set. 2018.

Memória de Reunião do Comitê Gestor do ICMBio. Brasília, 23 maio 2012.

Disponível em:

<http://www.icmbio.gov.br/portal/images/Memória\%20de\%20\%20Reunião\%20do\%20dia\%2 023\%20de\%20maio_ret.pdf >. Acesso em: 15 set. 2018.

SIGTERRA auxiliará na desapropriação em Unidades de Conservação: ICMBio lançou sistema de informações que mostrará imóveis em sobreposição com UCs. Brasília, 31 mar. 2015. Disponível em: <http://www.icmbio.gov.br/portal/ultimas-noticias/4destaques/6749-sigterra-auxiliara-na-desapropriacao-em-unidades-de-conservacao >. Acesso em: 31 mar. 2015.

Instrução Normativa no 5, de 19 de Maio de 2016. Estabelece os procedimentos para a Compensação de Reserva Legal, em imóveis localizados no interior de Unidades de Conservação Federais de domínio público, visando à regularização da sua situação fundiária, conforme Processo Administrativo no 02070.000195/2014-01. Disponível em:

<http://www.icmbio.gov.br/portal/images/stories/portarias/DCOM_ICMBio_Instrucao_Norm ativa_05_de_19_de_maio_de_2016.pdf>. Acesso em: 25 set. 2018.

Compensação de Reserva Legal. 2016. Disponível em:

<http://www.icmbio.gov.br/portal/compensacaodereservalegal >. Acesso em: 15 maio. 2016.

Conquistas na regularização fundiária. Brasília, 31 ago. 2017. Disponível em:

<http://www.icmbio.gov.br/portal/ultimas-noticias/20-geral/9122-conquistas-na-

regularizacao-fundiaria>. Acesso em: 21 nov. 2017.

ICMBIO/MMA. Cartilha de regularização fundiária de Unidades de Conservação

Federais. Apoio da Conservation International (TNC) e da Fundação SOS Mata Atlântica.

Brasília, [2011]. Disponível em:

<http://www.icmbio.gov.br/portal/images/stories/comunicacao/cartilha_de_regularizacao_fun diaria.pdf $>$. Acesso em: 06 out. 2015.

IPAM - INSTITUTO DE PESQUISA AMBIENTAL DA AMAZÔNIA. Cotas de Reserva Ambiental (CRA) para a conservação e o desenvolvimento sustentável: informações básicas para tomadores de decisão nos Estados. Brasília, DF, 2015. 
IRIGARAY, Carlos T. J. H. Compensação de reserva legal: limites a sua implementação. Revista Amazônia Legal: de estudos sócio-jurídico-ambientais, Cuiabá, n. 1, p. 55-68, jan./jul. 2007.

IWAMA, Allan Yu; LIMA, Fábio Bueno de; PELLIN, Angela. Questão fundiária em áreas protegidas: Uma experiência no Parque Estadual da Pedra Branca (PEPB), Rio de Janeiro, Brasil. Sociedade \& Natureza, Uberlândia, v. 26, n. 1, p. 77-93, jan./abr. 2014.

JACOBI, Pedro Roberto; RICHARD, Sophie; RIEU, Thierry. Governance. [2018]. No prelo.

JESSOP, Bob. Governance and Meta-governance: On Reflexivity, Requisite Variety, and Requisite Irony. In: BANG, Henrik (Ed.). Governance as Social and Political Communication. Manchester: Manchester University Press, 2003. p. 101-116.

JOLY, Carlos A. et al. Impactos potenciais das alterações propostas para o Código Florestal Brasileiro. 2011. Disponível em: <http://www2.unesp.br/revista/wpcontent/uploads/2010/10/Biota-Fapesp-ABECO-Sintese-CFB-e- biodiversidade.pdf $>$. Acesso em: 15 set. 2018.

KLINK, Carlos A.; MACHADO, Ricardo B. A conservação do Cerrado brasileiro. Megadiversidade, v. 1, n. 1, p. 147-155, jul. 2005.

KURY, Karla Aguiar. Regularização Fundiária em Unidade de Conservação: O caso do Parque Estadual do Desengano/RJ. 2009. 205 p. Dissertação (Mestrado em Engenharia Ambiental)-Instituto Federal de Educação Ciência e Tecnologia Fluminense, Rio de Janeiro, 2009.

LUSTOSA, Maria C. J.; CÁNEPA, Eugenio M.; YOUNG, Carlos E. F. Política Ambiental. In: MAY, Peter H. (Org.). Economia do Meio Ambiente: teoria e prática. 2. ed. Rio de Janeiro: Elsevier, 2010. p. 163-179.

LUSTOSA, Maria Cecília J.; YOUNG, Carlos E. F. Política Ambiental. In:

HASENCLEVER, Lia; KUPFER, David (Org.). Economia Industrial: fundamentos teóricos e práticas no Brasil. Rio de Janeiro: Campus, 2002.

MACHADO, Lourdes de Alcantara. Cadastro ambiental rural e as cotas de reserva ambiental no novo código florestal: uma análise de aspectos legais essenciais para a sua implementação. In: SILVA, Ana Paula Moreira da; MARQUES, Henrique Rodrigues; SAMBUICHI, Regina Helena Rosa. Mudanças no código florestal brasileiro: desafios para a implementação da nova lei. Rio de Janeiro: Ipea, 2016. p. 45-77.

MACHADO, Ricardo B. et al. Estimativas de perda da área do Cerrado brasileiro. Relatório técnico não publicado. Brasília, DF: Conservação Internacional, jul. 2004. Disponível em: <http://www.conservation.org.br/arquivos/RelatDesmatamCerrado.pdf>. Acesso em: 18 out. 2018.

MAGRINI, Alessandra. Política e gestão ambiental: conceitos e instrumentos. Revista Brasileira de Energia, v. 8, n. 2, p. 1-8, 2001. 
MAY, Peter et al. Environmental reserve quotas in Brazil's new forest legislation: An ex ante appraisal. Indonesia: Center for International Forestry Research (CIFOR), 2015.

MAYNTZ, Renate. El Estado y la sociedad civil en la gobernanza moderna. Revista del CLAD Reforma y Democracia, Caracas, n. 21, p. 1-8, Oct. 2001.

MEDEIROS, Rodrigo; YOUNG; Carlos E. F. Contribuição das Unidades de Conservação brasileiras para a economia nacional: relatório final. Brasília: Unep-WCMC, 2011. 120 p.

MESQUITA, Humberto N. de et al. Relatório Técnico de Monitoramento do

Desmatamento no Bioma Cerrado, 2002 a 2008: Dados Revisados. Brasil: MMA; Ibama; Pnud, 2009.

METZGER, Jean P. O Código Florestal tem base científica? Natureza \& Conservação, v. 8, n. 1, p. 1-5, 2010.

MMA - MINISTÉRIO DO MEIO AMBIENTE. Consolidação territorial de Unidades de Conservação. Apresentação de Eliane Maciel Lima. Coordenadora-Geral de Consolidação Territorial. Brasília, set. 2011. Disponível em:

<http://www.mma.gov.br/estruturas/201/_arquivos/consolidao_territorial_de_ucs_eliani_lima _201.pdf>. Acesso em: 15 set. 2018.

Sistema Nacional de Unidades Conservação - SNUC, 2015. Disponível em:

<http://www.mma.gov.br/areas-protegidas/sistema-nacional-de-ucs-snuc >.

MONZONI, Mario; VENDRAMINI, Annelise. Cotas de Reserva Ambiental (CRA). São Paulo: GVces/FGV-EAESP, 2015.

MOTTA, Ronaldo Seroa da. Instrumentos econômicos e política ambiental. Revista do Direito Ambiental, São Paulo, v. 5, n. 20, p. 86-93, out./dez. 2000.

MOTTA, Ronaldo Seroa da. Instrumentos Econômicos: Conceitos objetivos e resultados. In: AZEVEDO, Andrea A.; REIS, Tiago; PIRES, Mauro (Org.). Instrumentos Econômicos de Apoio a Implementação do Novo Código Florestal. Relato do workshop no âmbito do Observatório do Código Florestal. São Paulo: Observatório do Código Florestal, 2014. p. 7-8.

MOTTA, Ronaldo S. da; RUITENBEEK, Jack; HUBER, Richard. Uso de instrumentos econômicos na gestão ambiental da América Latina e Caribe: lições e recomendações. Rio de Janeiro: Ipea, out. 1996. (Texto para Discussão, n. 440).

NUSDEO, Ana Maria de Oliveira. Pagamento por serviços ambientais: sustentabilidade e disciplina jurídica. São Paulo: Atlas, 2012.

OLIVEIRA, Evelinn Flores de. Regularização Fundiária em Reservas de Desenvolvimento Sustentável do Estado do Amazonas. 2009. 121 p. Dissertação (Mestrado em Direito Ambiental)-Universidade Estadual do Amazonas, Manaus, 2009.

OLIVEIRA, Ludmila Junqueira Duarte. Regularização fundiária de unidades de conservação. Boletim Científico, Escola Superior do Ministério Público da União, Brasília-DF, ano 9, n. 32/33, p. 143-176, jan./dez. 2010. 
PALMER, David et al. Towards improved land governance. [S.1.]: FAO, 2009. (Land Tenure Working Paper, 11). Disponível em: 〈http://www.fao.org/3/a-ak999e.pdf〉. Acesso em: 15 set. 2018.

PELLIN, Angela et al. Compensação ambiental como fonte de recursos para unidades de conservação: situação atual e aspectos polêmicos. OLAM Ciência \& Tecnologia, Rio ClaroSP, ano VII, v. 7, n. 2, p. 171-186, dez. 2007.

PEREIRA, Polyana Faria; SCARDUA, Fernando Paiva. Espaços territoriais especialmente protegidos: conceito e implicações jurídicas. Ambient. soc. [online], 2008, v. 11, n. 1, p. 8197. Disponível em: <http://dx.doi.org/10.1590/S1414-753X2008000100007>. Acesso em: 15 set. 2018.

PIRES, Mauro O. O cadastro Ambiental rural: das origens às perspectivas para a política ambiental. Brasília: Conservação Internacional, 2013.

PIRES, Mauro Oliveira; SAVIAN, Gabriela Canto Pires Santos. A implementação da política de regularização ambiental nos estados da Amazônia e as propostas de alteração da Lei $\mathbf{n}^{\circ}$ 12.651, de 2012. In: SILVA, Ana Paula Moreira da; MARQUES, Henrique Rodrigues; SAMBUICHI, Regina Helena Rosa. Mudanças no código florestal brasileiro: desafios para a implementação da nova lei. Rio de Janeiro: Ipea, 2016. p. 79-106.

RAJÃO, Raoni; SOARES-FILHO, Britaldo. Cotas de Reserva Ambiental (CRA): potencial e viabilidade econômica do mercado no Brasil. Belo Horizonte: IGC/UFMG, 2015.

REYDON, Bastiaan P. A regulação institucional da propriedade da terra no Brasil: Uma necessidade urgente. E-Premissas: Revista de Estudos Estratégicos, Unicamp, Campinas, n. 2, p. 25-60, jan./jun. 2007.

REYDON, Bastiaan P. et al. Instituições e administração fundiária. In: REYDON, Bastiaan P. et al. (Ed.). Governança de terras: da teoria à realidade brasileira. Brasília: FAO/SEAD, 2017.

REYDON, Bastiaan P.; BUENO, Ana Karina Silva; BUENO, Ana Paula. Sistemas de Cadastros no Brasil. Relatório Técnico. Convênio FAOJINCRAIUNICAMP. Instituto de Economia, Unicamp. Campinas: Unicamp, 2015.

REYDON, Bastiaan P.; BUENO, Ana P. S.; SIQUEIRA, Gabriel P. Histórico e dinâmica dos diferentes cadastros de terras do Brasil. In: REYDON, Bastiaan et al. (Ed.). Governança de terras: da teoria à realidade brasileira. Brasília: FAO/SEAD, 2017. p. 127-159.

REYDON, Bastiaan P.; FELÍCIO, Adâmara S. G. Fundamentos da governança fundiária. In: REYDON, B. P et al. (Ed.). Governança de terras: da teoria à realidade brasileira. Brasília: FAO/SEAD, 2017. p. 13-41.

REYDON, Bastiaan P.; FERNANDES, Vitor B.; TELLES, Tiago S. Land tenure in Brazil: The question of regulation and governance. Land Use Policy, v. 42, p. 509-516, jan. 2015. 
REZENDE, Gervásio Castro de. Ocupação agrícola e estrutura agrária no Cerrado: o papel do preço da terra, dos recursos naturais e da tecnologia. Rio de Janeiro: IPEA, 2002. (Texto para discussão, $n^{\circ}$ 913).

ROCHA, Ibraim. Posse e domínio da regularização de unidades de conservação: Visão de um amazônida. In: CONGRESSO BRASILEIRO DE UNIDADES DE CONSERVAÇÃO, 3. 2002, Fortaleza -CE. Anais... Fortaleza: Fundação Grupo Boticário, 2002. v. 1, p. 811-812.

ROCHA, Leonardo; DRUMMOND, José A.; GANEM, Roseli S. Parques Nacionais Brasileiros: problemas fundiários e alternativas para a sua solução. Revista de Sociologia e Política, Curitiba, v. 18, n. 36, p. 205-226, jun. 2010.

SARETTA, Cássia. Compensação de Reserva Legal em Unidade de Conservação: trajetórias, fortalezas, oportunidades e desafios. 2017. 136 p. Dissertação (Mestrado em Desenvolvimento Econômico)-Instituto de Economia, Universidade Estadual de Campinas, 2017.

SAVIAN, Moisés et al. Cadastro ambiental rural: experiências e potencialidades para a gestão agroambiental. In: SAMBUICHI, Regina H. R. et al. (Org.). Políticas agroambientais e sustentabilidade: desafios, oportunidades e lições aprendidas. Brasília: Ipea, 2014. p. 105124.

SILVA, José A. A. de (Coord.). O Código Florestal e a ciência: contribuições para o diálogo. 2. ed. São Paulo: SBPC, 2012. Disponível em:

<http://www.sbpcnet.org.br/site/publicacoes/outras-publicacoes/CodigoFlorestal_2aed.pdf >. Acesso em: 15 set. 2018.

SILVA, Solange T. da et al. Código Florestal: em defesa das nossas florestas e do nosso futuro. In: LAVRATTI, Paula; PRESTES, Vanêsca Buzelato (Org.). Direito e mudanças climáticas: a reforma do Código Florestal: limites jurídicos. São Paulo: Instituto Direito por um Planeta Verde, 2010. p. 9-32.

SILVA, Ana P. M da; MARQUES, Henrique R.; SAMBUICHI, Regina H. R. (Org.). Mudanças no código florestal brasileiro: desafios para a implementação da nova lei. Rio de Janeiro: IPEA, 2016.

SILVA, Jéssica S; RANIERI, Victor E. L. O mecanismo de compensação de reserva legal e suas implicações econômicas e ambientais. Ambiente \& Sociedade, São Paulo, v. 17, n. 1, p. 115-132, jan./mar. 2014. Disponível em: <http://www.scielo.br/scielo. php?script=sci_arttext\&pid=S1414-753X2014000100008>. Acesso em: 15 set. 2018.

SFB - SERVIÇO FLORESTAL BRASILEIRO. Números do Cadastro Ambiental Rural. 2016. Disponível em: <http://www. florestal.gov.br/cadastro-ambiental-rural/numeros-docadastro-ambiental-rural $>$. Acesso em: 15 set. 2016.

SOARES, Samira Iasbeck de Oliveira. A mediação de conflitos na gestão de recursos hídricos no Brasil. 2008. 172 p. Dissertação (Mestrado em Ciência Ambiental)-Universidade de São Paulo, São Paulo, 2008. 
SOARES-FILHO, Britaldo et al. Cracking Brazil's Forest Code. Science, v. 344, n. 6.182, p. 363-364, 25 Apr. 2014.

SPAROVEK, Gerd. Caminhos e escolhas na revisão do Código Florestal: quando a compensação compensa? Visão agrícola, n. 10, p. 25-28, jan./abr. 2012.

SPAROVEK, Gerd et al. Brazilian Agriculture and Environmental Legislation: Status and Future Challenges. Environmental Science \& Technology, v. 44, n. 16, p. 6046-6053, 15 ago. 2010.

A revisão do Código Florestal Brasileiro. Novos Estudos, n. 89, p. 111-135, 2011.

STEINWEG, Tim; KUEPPER, Barbara; THOUMI, Gabriel. Farmland Investments in Brazilian Cerrado: Financial, Environmental and Social Risks. Chain Reaction Research, United States, 20 Sept. 2017. Disponível em:

$<$ https://chainreactionresearch.files.wordpress.com/2017/10/farmland-investments-inbrazilian-Cerrado-v2.pdf>. Acesso em: 18 out. 2018.

TANSEY, Kevin et al. Vegetation burning in the year 2000: Global burned area estimates from SPOT VEGETATION data. Journal of Geophysical Research D: Atmospheres, v. 109, n. 14, p. 1-22, 2004.

TCU - TRIBUNAL DE CONTAS DA UNIÃO. Relatório de Auditoria (RA). Auditoria Operacional: Governança das Unidades de Conservação do bioma amazônico. Processo 034.496/2012-2, Acórdão 3101/2013, Ata 46/2013. Brasília, 20 nov. 2013. Disponível em: <https://contas.tcu.gov.br/juris/SvlHighLight?key=41434f5244414f2d434f4d504c45544f2d31 313239343830\&sort=RELEVANCIA\&ordem=DESC\&bases=ACORDAO-

COMPLETO; $\&$ highlight $=\&$ posicaoDocumento $=0 \&$ numDocumento $=1 \&$ totalDocumentos $=1>$ . Acesso em: 10 out. 2018.

UNITED NATIONS. Governance. [2018]. Disponível em:

<http://www.un.org/en/globalissues/governance>. Acesso em: 15 set. 2018.

VIEIRA FILHO, José E. R. Expansão da Fronteira Agrícola no Brasil: Desafios e Perspectivas. Rio de Janeiro: Ipea, 2016. (Texto para discussão, n. 2.223).

WILLIAMSON, Ian et al. Land administration for sustainable development. Redlands, California: ESRI Press Academic, 2010.

WORLD BANK. Avaliação da governança fundiária no Brasil. 2014. Disponível em: <http://siteresources.worldbank.org/INTLGA/Resources/Brazil_land_governance_assessment _final_Portuguese.pdf $>$. Acesso em: 15 set. 2018. 
ANEXO 1 - Mapas das estações ecológicas do bioma Cerrado

\begin{tabular}{|c|c|c|c|}
\hline Estação Ecológica de Ibicatu & SP & $\mathrm{EE}$ & Estadual \\
\hline Estação Ecológica de Iquê & MT & $\mathrm{EE}$ & Federal \\
\hline Estação Ecológica de Itapeva & SP & $\mathrm{EE}$ & Estadual \\
\hline Estação Ecológica de Itirapina & SP & $\mathrm{EE}$ & Estadual \\
\hline Estação Ecológica de Jataí & SP & $\mathrm{EE}$ & Estadual \\
\hline Estação Ecológica de Mogi Guaçu & SP & $\mathrm{EE}$ & Estadual \\
\hline Estação Ecológica de Paranapanema & SP & $\mathrm{EE}$ & Estadual \\
\hline Estação Ecológica de Pirapitinga & $\mathrm{MG}$ & $\mathrm{EE}$ & Federal \\
\hline Estação Ecológica de Riberão Preto & SP & $\mathrm{EE}$ & Estadual \\
\hline Estação Ecológica de Santa Bárbara & SP & $\mathrm{EE}$ & Estadual \\
\hline Estação Ecológica de Santa Maria & SP & $\mathrm{EE}$ & Estadual \\
\hline Estação Ecológica de Uruçuí-Una & PI & $\mathrm{EE}$ & Federal \\
\hline Estação Ecológica do Barreiro Rico & SP & $\mathrm{EE}$ & Estadual \\
\hline Estação Ecológica do Rio Preto & BA & $\mathrm{EE}$ & Estadual \\
\hline Estação Ecológica Estadual de Sagarana & MG & $\mathrm{EE}$ & Estadual \\
\hline Estação Ecológica Itaberá & SP & $\mathrm{EE}$ & Estadual \\
\hline Estação Ecológica Jardim Botânico de Brasília & DF & $\mathrm{EE}$ & Estadual \\
\hline Estação Ecológica Mata do Jacaré & SP & $\mathrm{EE}$ & Estadual \\
\hline Estação Ecológica Mata dos Ausentes & MG & $\mathrm{EE}$ & Estadual \\
\hline Estação Ecológica Serra das Araras & MT & $\mathrm{EE}$ & Federal \\
\hline Estação Ecológica Serra Geral do Tocantins & $\mathrm{BA} / \mathrm{TO}$ & $\mathrm{EE}$ & Federal \\
\hline
\end{tabular}



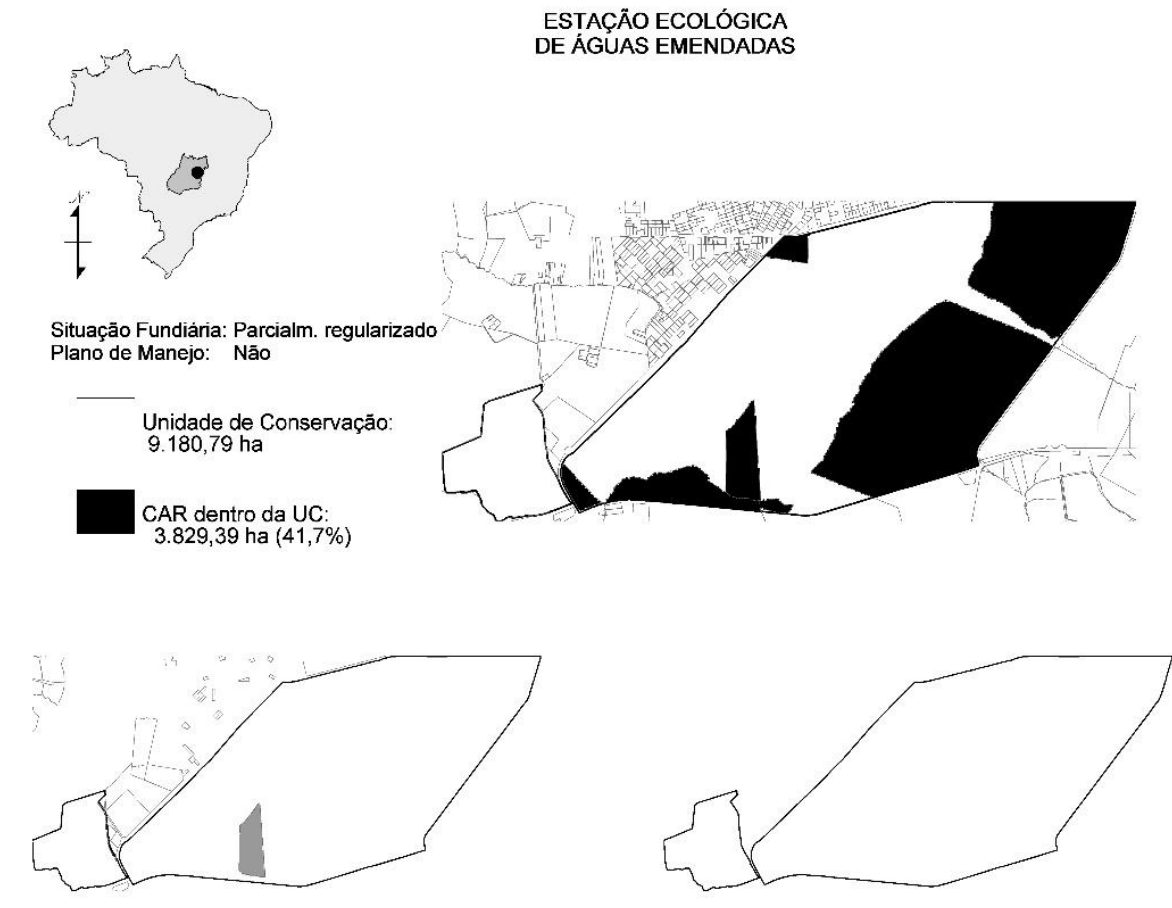

SIGEF Particular: $\quad \square$
$12,79(1,6 \%)$$\quad \begin{aligned} & \text { SIGEF Público: } \\ & 206,26(2,4 \%)\end{aligned}$

Terra Indigena: $\quad-\begin{gathered}\text { Assentamento Rural: } \\ 0(0 \%) \\ 0(0 \%)\end{gathered}$
0.

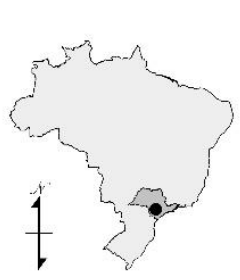

ESTACÃO ECOLÓGICA

Situação Fundiária: Totalm. regularizado Plano de Manejo: Não

Unidade de Conservação
$1.362,89$ ha

CAR dentro da UC
15,77 ha $(1,2 \%)$

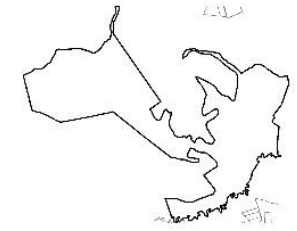

SIGEF Particular.

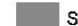

SIGEF Público: DE ANGATUBA
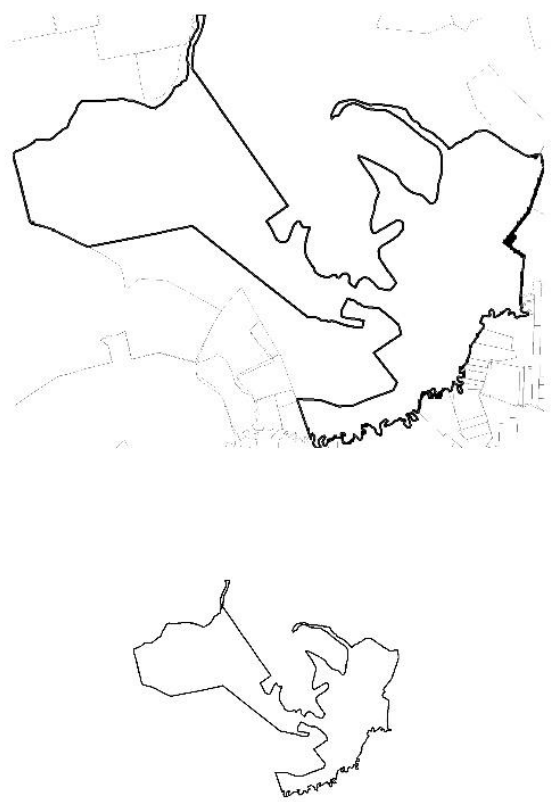

Terra Indigena
$0(0 \%)$ Assentamento Rura: $0(0 \%)$ 


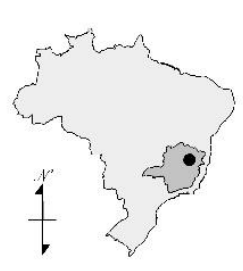

ESTAÇÃO ECOLÓGICA

Situaçăo Fundiária: Totalm. regularizado Plano de Manejo: Não

$$
\text { DE ACAUĀ }
$$
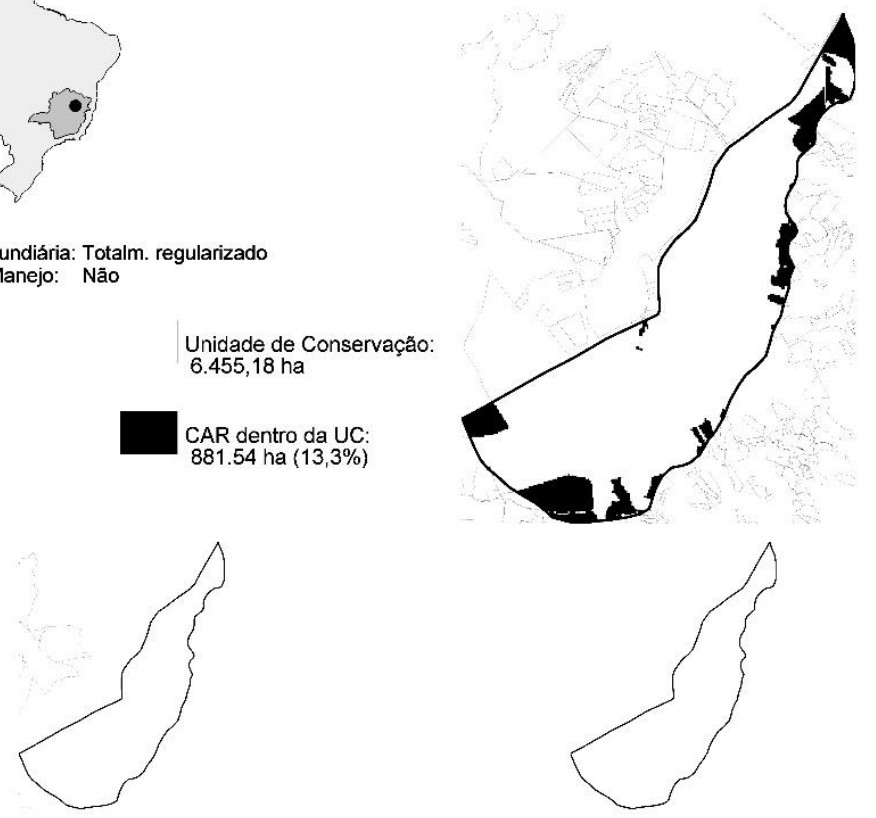

SIGEF Particula

SIGEF Público:
$0(0 \%)$

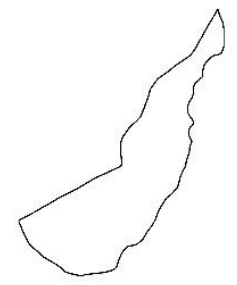

Unidade de Conservação:

CAR dentro da UC:

881.54 ha $(13,3 \%)$
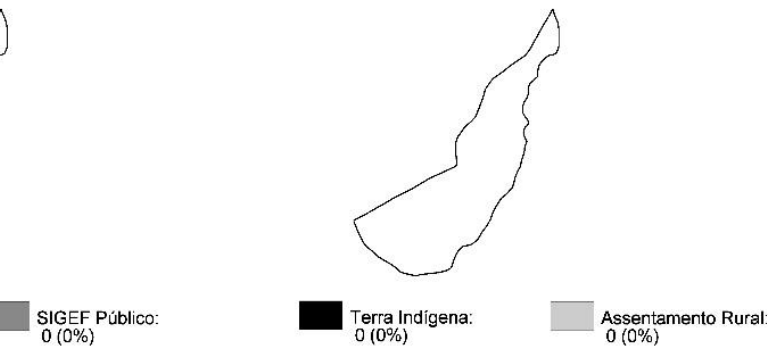

ESTAÇÃO ECOLÓGICA

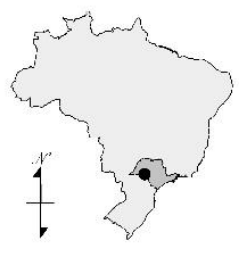

DE ASSIS

Situaçăo Fundiária: Totalm. regularizado

Plano de Manejo: Sim
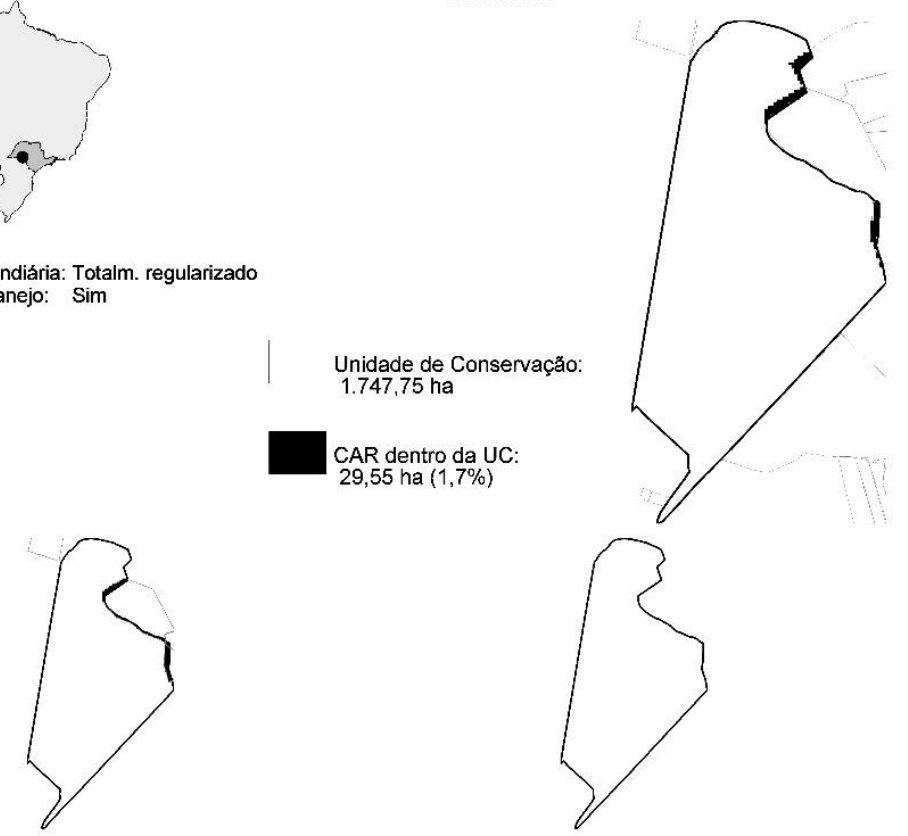

29,55 ha $(1,7 \%)$

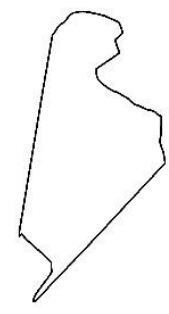

$\mathbb{W}_{35,76(1,9 \%)}$

$\square$ SIGEF Püblico.

Terra Indigena

Assentamento Rural 


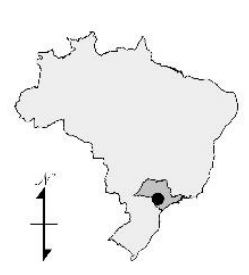

Situaçāo Fundiária: Totalm. regularizado Plano de Manejo: Não

ESTAÇÃO ECOLÓGICA

DE AVARÉ

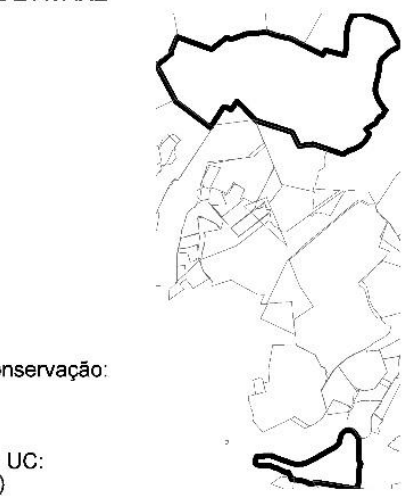<smiles>C1CCCCCCCCCCCC1</smiles><smiles>C1CCCCCCCCCCCCC1</smiles>

Unidade de Conservação:
720,08 ha

CAR dentro da UC:

5,91 ha $(0,8 \%)$

$\simeq$

$\sim$

SIGEF Particular:

$\underset{0(0 \%)}{\text { SIGEF Público: }}$

Terra Indigena:

Assentamento Rural:
$0(0 \%)$

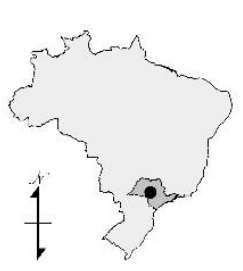

Situaçāo Fundiária: Totalm. regularizado Plano de Manejo: Nāo

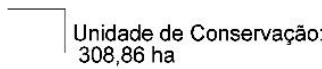

CAR dentro da UC
39.45 ha $(12,8 \%)$

ESTAÇĂO ECOLÓGICA DE BAURU
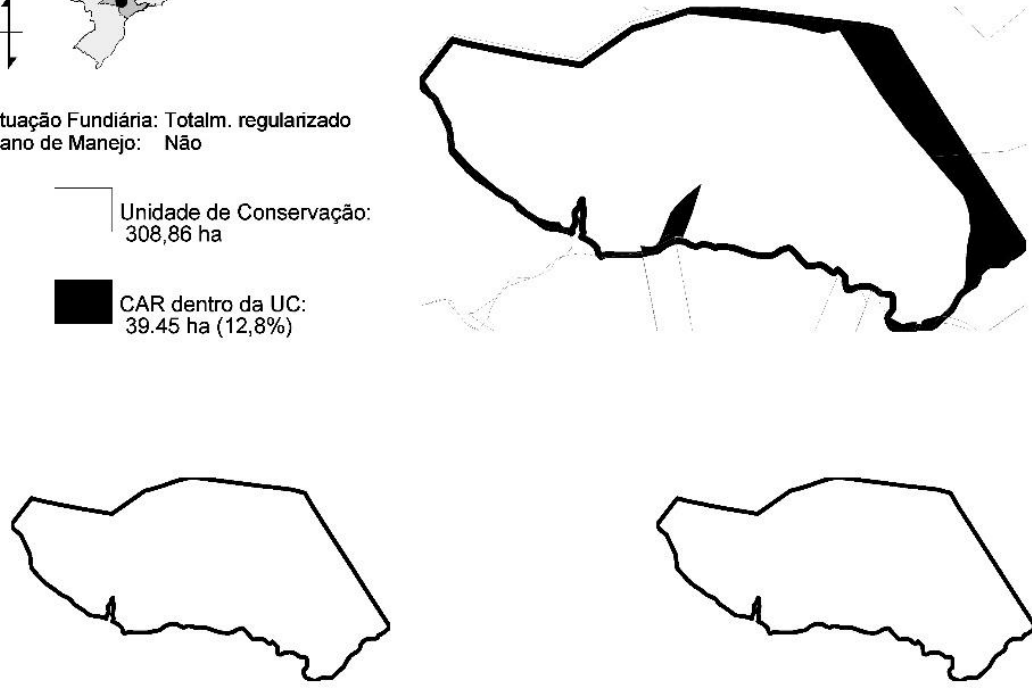

$\underset{0(0 \%)}{\text { SIGEF Particular: }}$

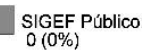

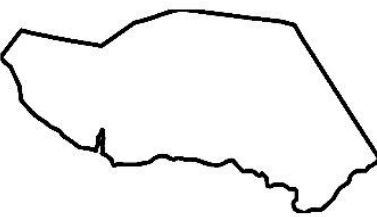

Torra Indigen

Assenta
$0(0 \%)$ 


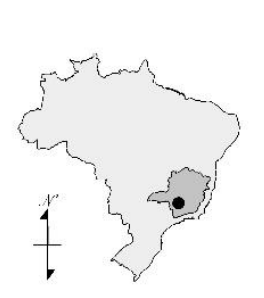

ESTAÇÄO ECOLÓGICA

DE CORUMBÁ

Situaçăo Fundiária: Não regularizado Plano de Manejo: Sim

Unidade de Conservação: 309,82 ha

CAR dentro da UC
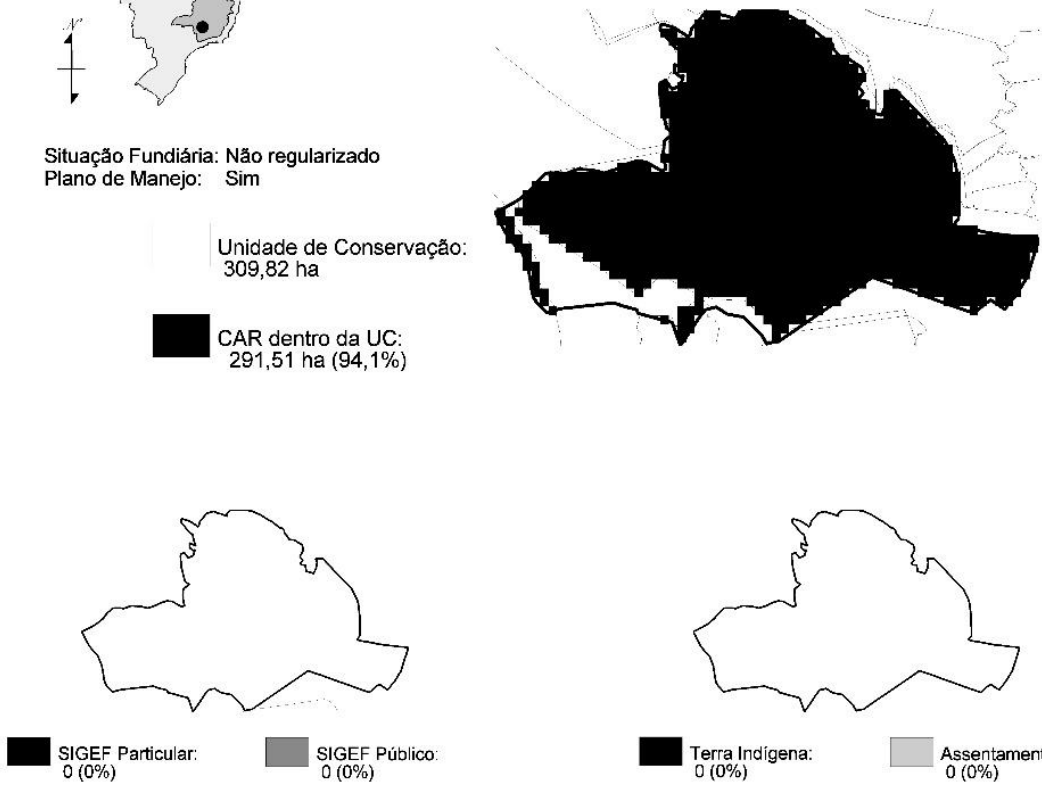

(0\%)

Terra Indigen
$0(0 \%)$

Assentamento Rural

ESTAÇÃO ECOLÓGICA

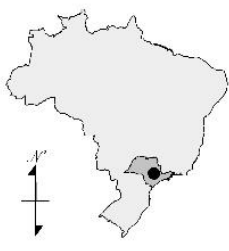

DE IBICATU

Situação Fundiária:

Plano de Manejo:

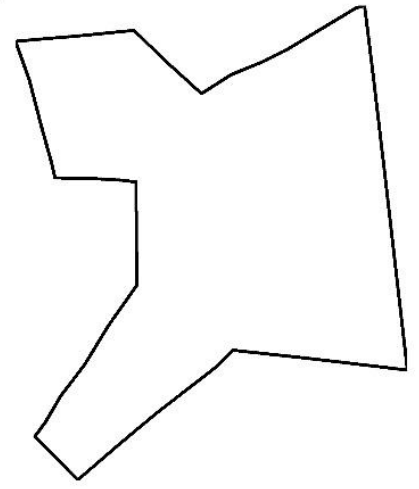

Unidade de Conservaça: 81,67 ha

CAR dentro da UC
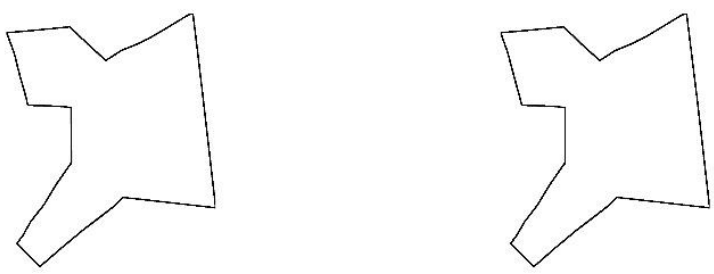

SIGEF Particular
$O(0 \%)$

SIGEF Público

Terra Indigen

Assentamento Rural
$0(0 \%)$ 


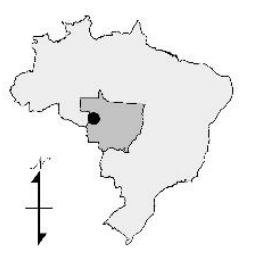

ESTAÇÃO ECOLÓGICA
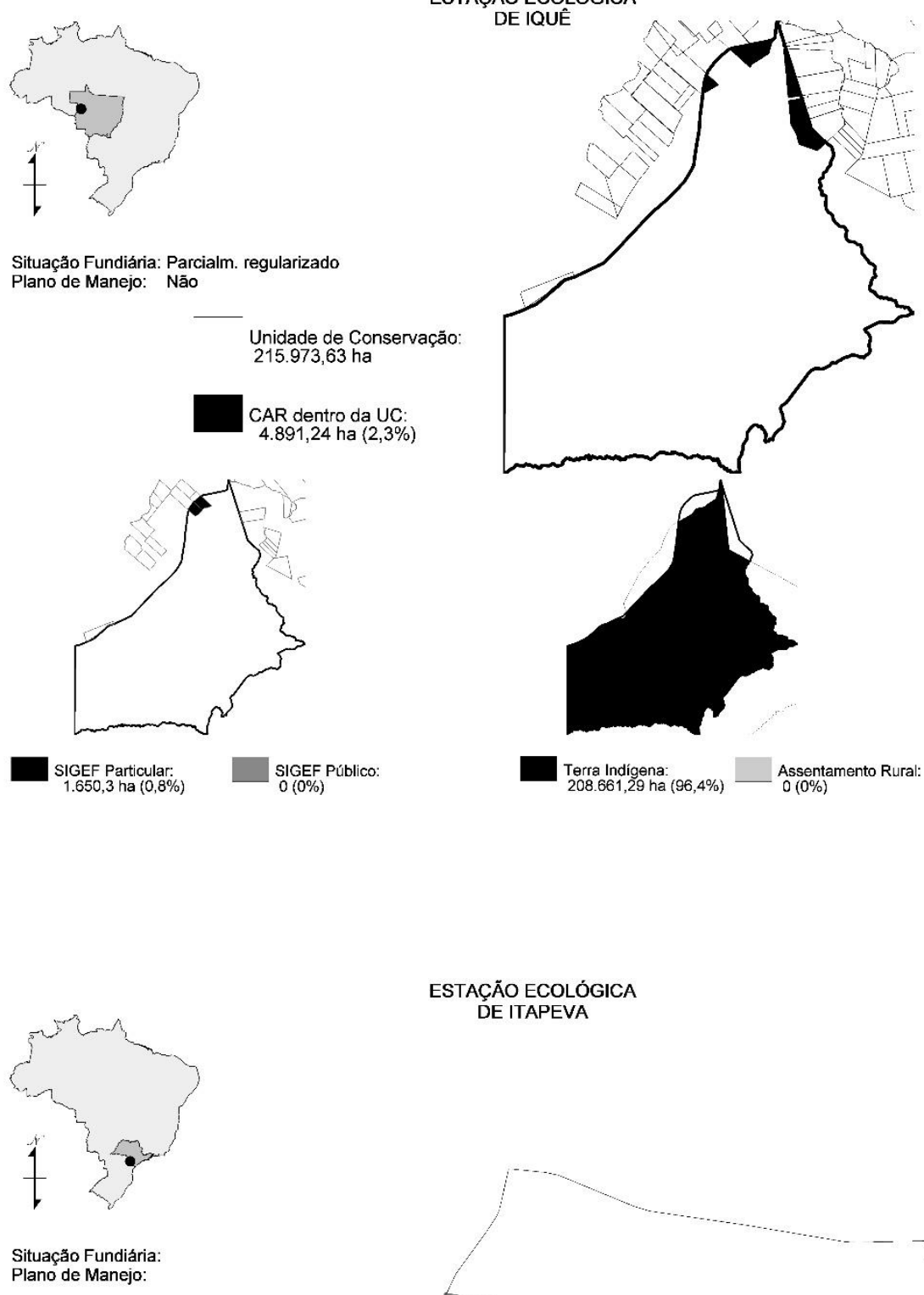

ESTAC̆̃O ECOLÓGICA

DE ITAPEVA

Unidade de Conservação: 99,23 ha

CAR dentro da UC:

25,23 ha $(25,4 \%)$
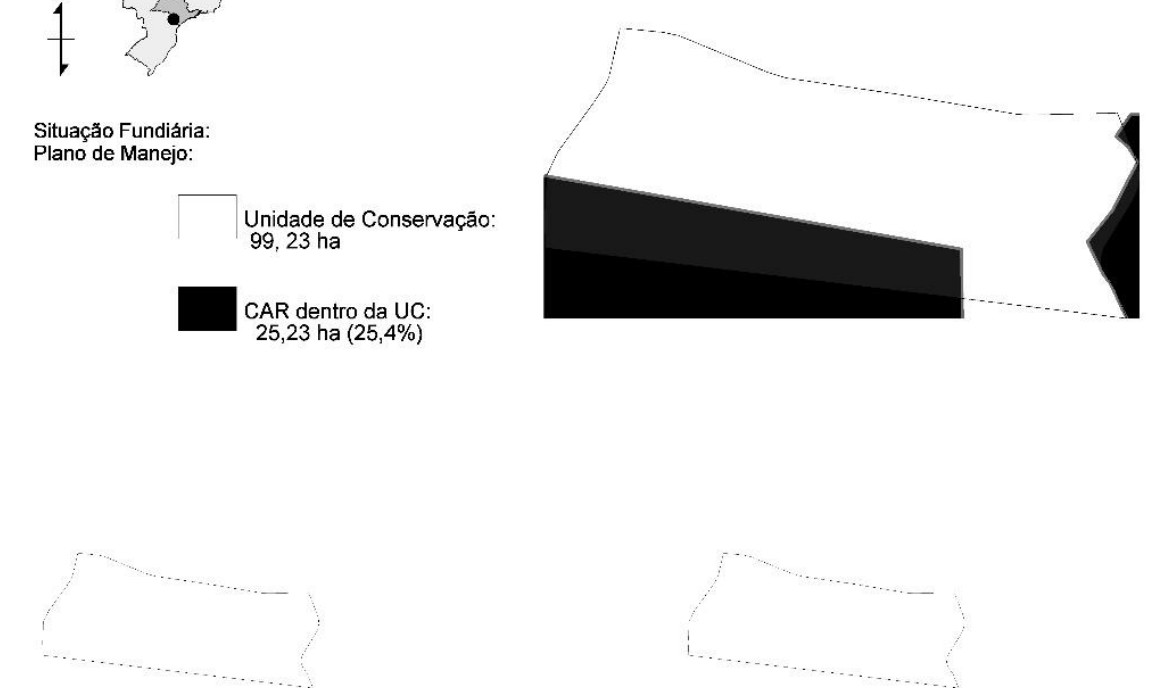

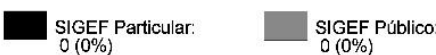

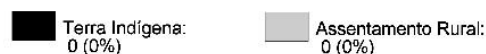




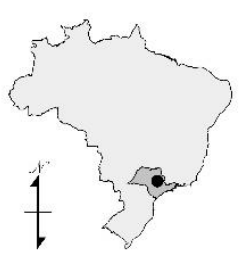

Situaçāo Fundiària: Totalm. regularizado Plano de Manejo: Não

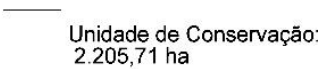
$2.205,71$ ha

CAR dentro da UC
199,91 ha $(9,1 \%)$

ESTAÇÃO ECOLÓGICA

DE ITIRAPINA
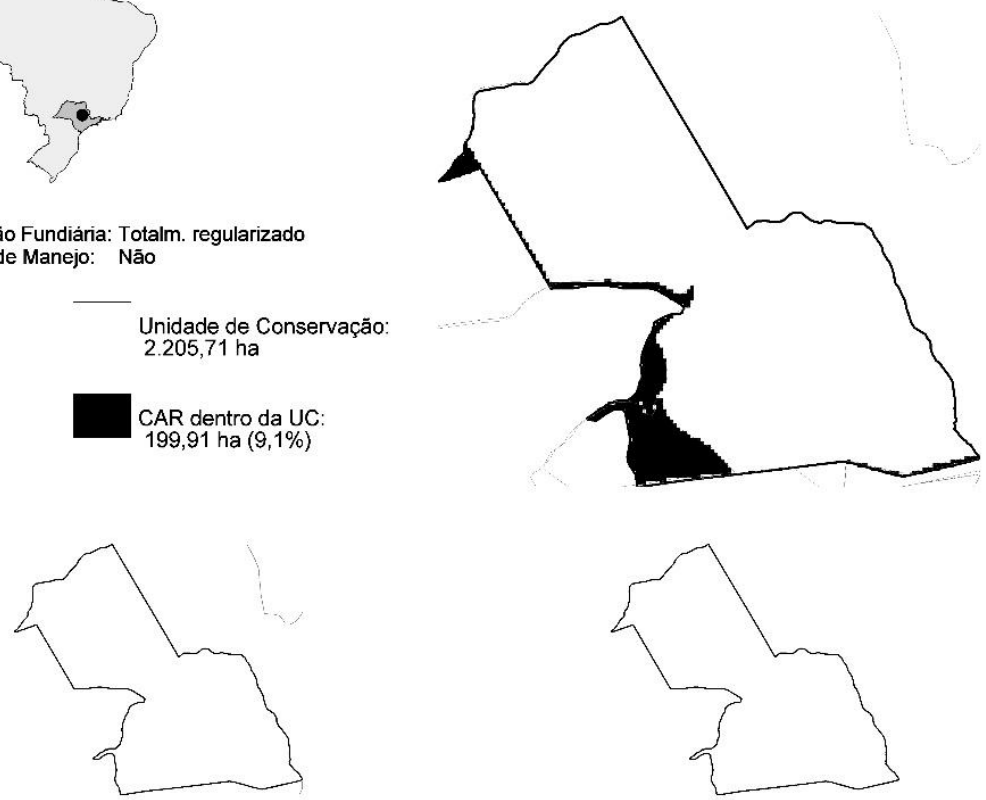

SIGEF Particular:
$0(0 \%)$$\quad \underset{0(0 \%)}{\text { SIGEF Público: }}$

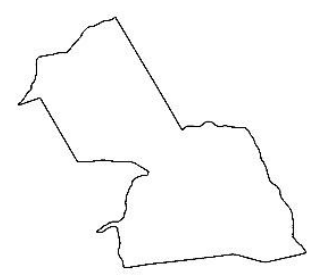

Terra Indigena: $\quad-\begin{gathered}\text { Assentamento Rural: } \\ 0(0 \%)\end{gathered}(0 \%)$
0.

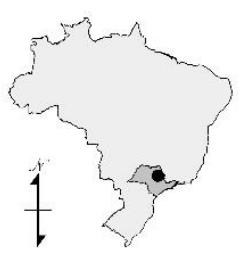

ESTAÇÄO ECOLÓGICA

Situação Fundiária: Totalm. regularizado Plano de Manejo:

Unidade de Conservação:
$9.000,10$ ha

CAR dentro da UC:

279,42 ha $(3,1 \%)$

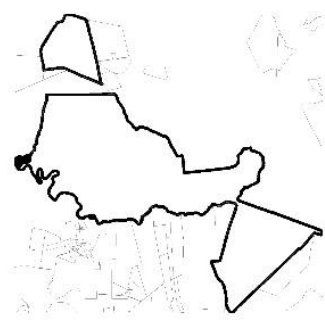

SIGEF Particular:
83,14 ha $(0,88 \%)$ SIGEF Público:
$0(0 \%)$
DE JATAÍ
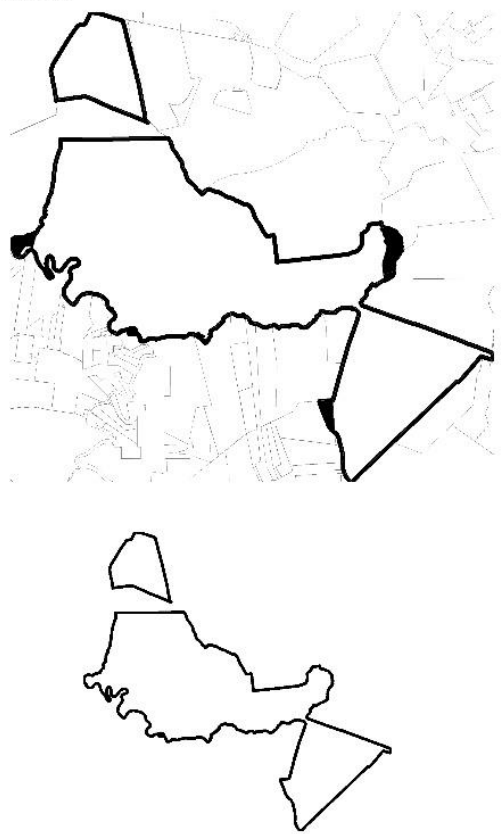

Terra Indigena: $\quad$ Assentamento Rura: 


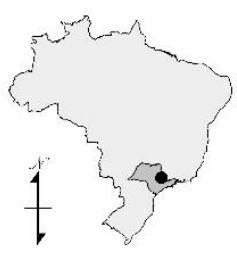

Situação Fundiảria: Totalm. regularizado Plano de Manejo: Não
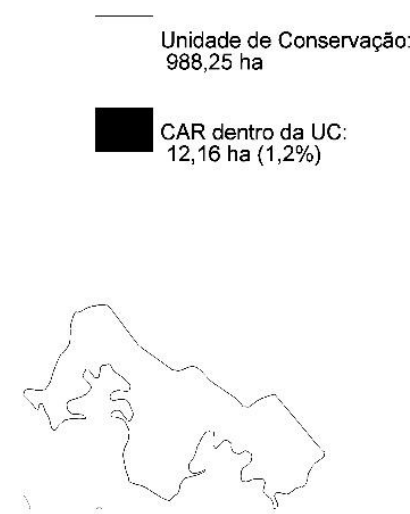

SIGEF Particular
$0(0 \%)$

SIGEF Público:
$0(0 \%)$

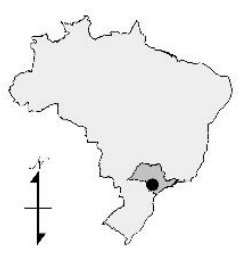

Situação Fundiária: Totalm. regularizado Plano de Manejo: Não

Unidade de Conservaçăo 634,52 ha

CAR dentro da UC:
0,80 ha $(0 \%)$

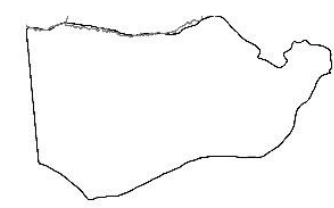

SIGEF Particular: $\underset{0(0 \%)}{\text { SIGEF Público: }}$
ESTAÇÃO ECOLÓGICA

DE MOGI-GUAÇU
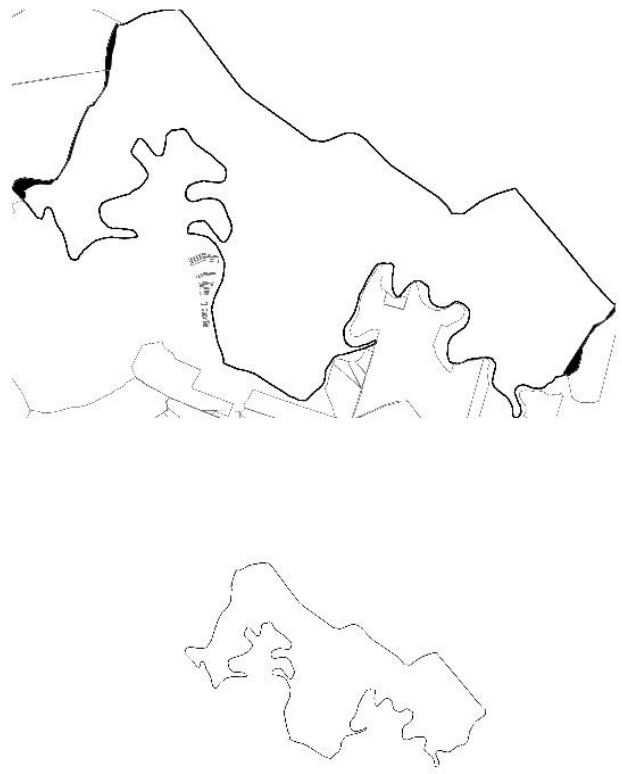

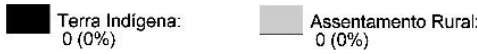

DSTAÇAOECOLOGICA
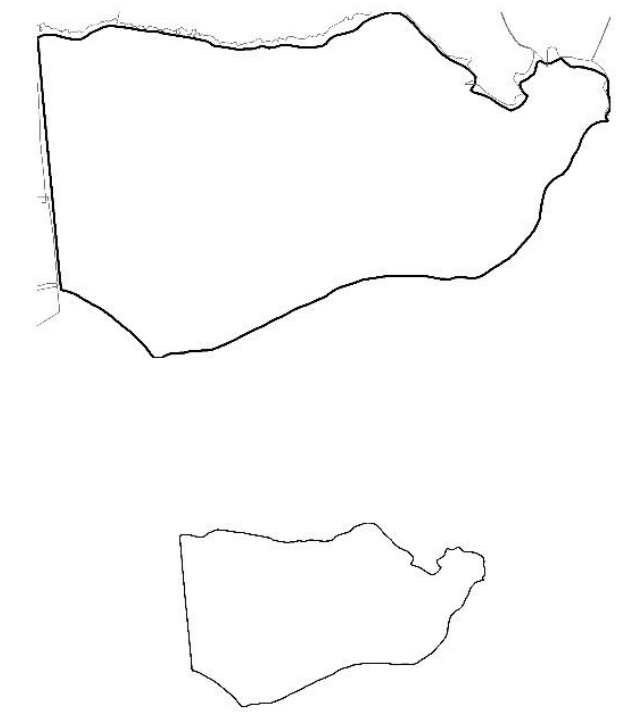

\begin{tabular}{c|c} 
Terra Indigena: \\
$0(0 \%)$
\end{tabular}$\quad \begin{gathered}\text { Assentamento Rural: } \\
0(0 \%)\end{gathered}$ 


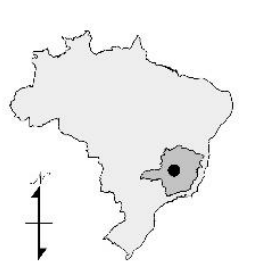

ESTAÇÄO ECOLÓGICA

DE PIRAPITINGA

Situaçăo Fundiária: Totalm. regularizado Plano de Manejo: Sim

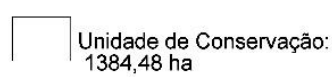
384,48 ha

CAR dentro da UC: $0(0 \%)$
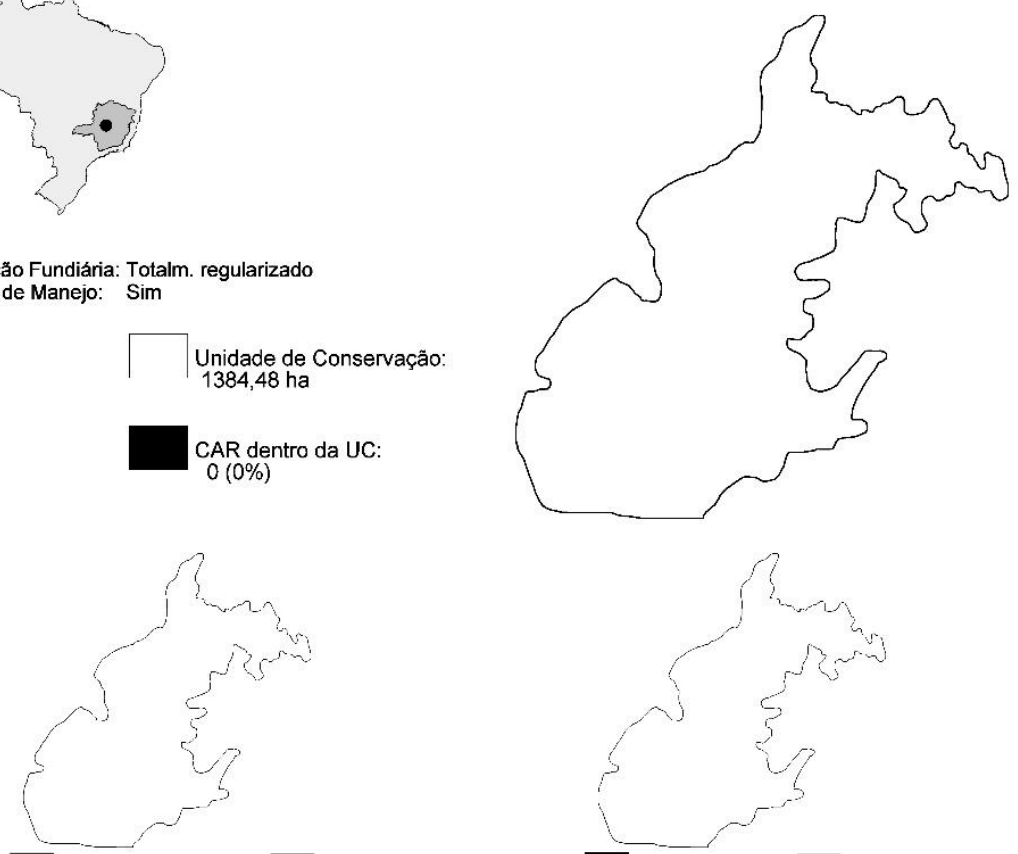

SIGEF Particular: $\quad$ SIGEF Público:
$0(0 \%)$

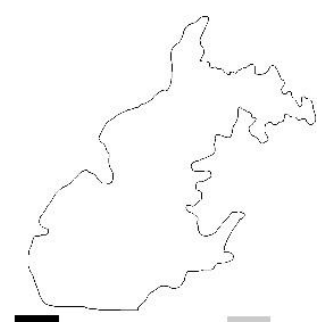

Terra Indigena:
$0(0 \%)$$\quad \begin{gathered}\text { Assentamento Rural: } \\ 0(0 \%)\end{gathered}$

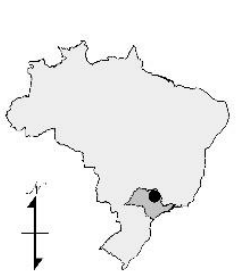

ESTACCÃO ECOLÓGICA

DE RIBEIRÃO PRETO

Situaçāo Fundiária: Totalm. regularizado

Plano de Manejo: Não

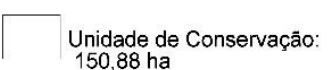

150,88 ha

CAR dentro da UC:

3,73 ha $(2,4 \%)$
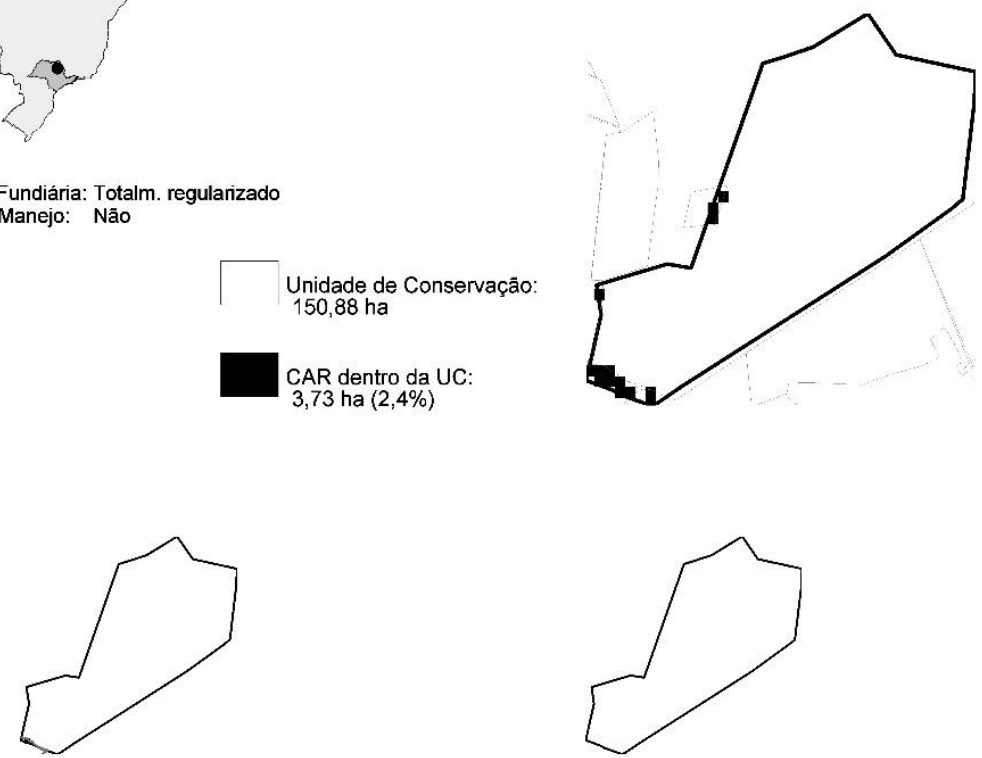

SIGEF Particular
0,35 ha $(0 \%)$

$\underset{0}{\text { SIGEF Público: }}$

Terra Indígen
$0(0 \%)$

Assentamento Rural: 


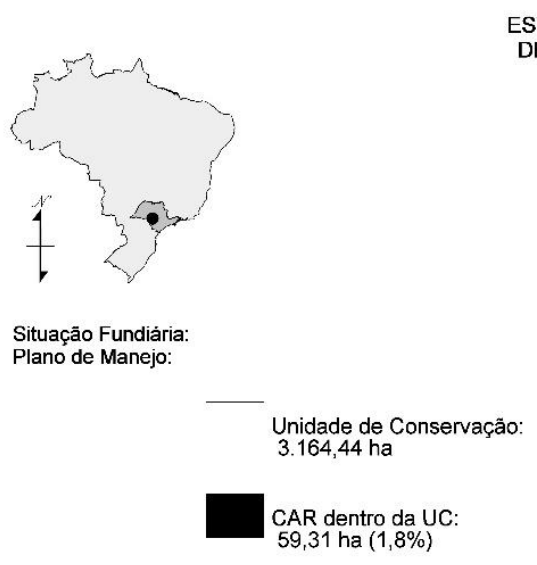

ESTAÇÃO ECOLÓGICA

DE SANTA BÁRBARA
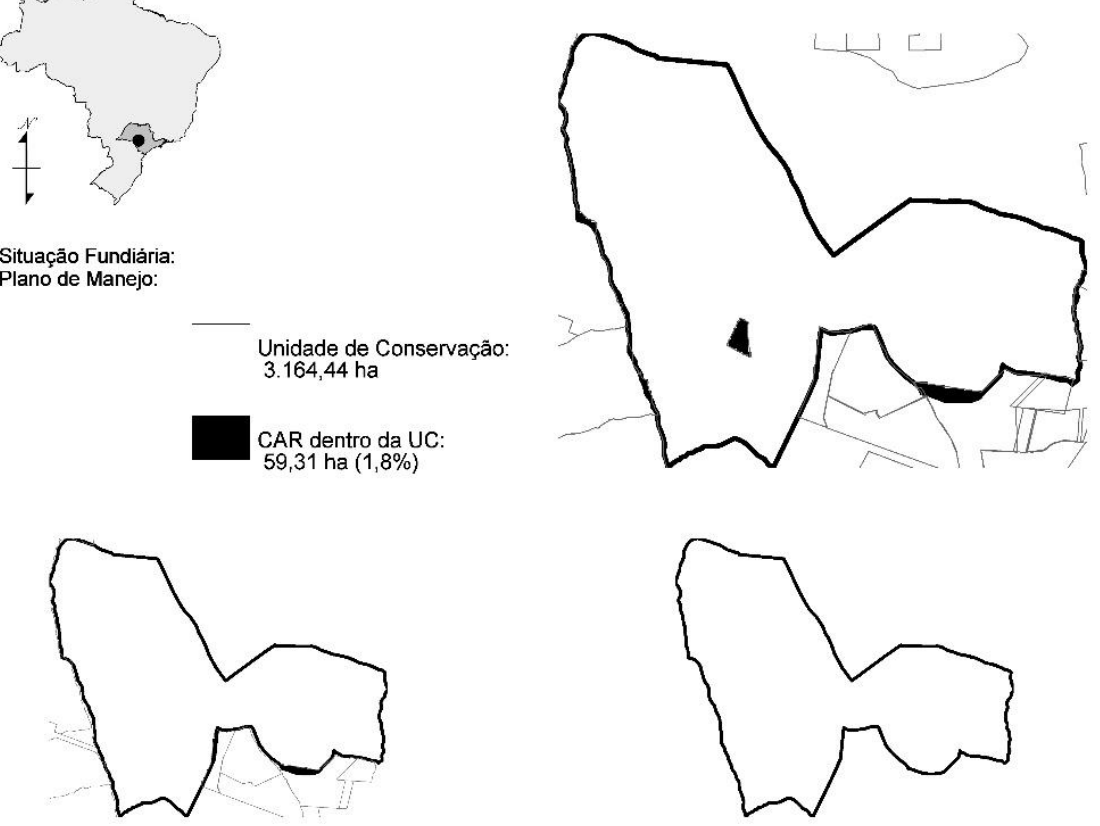

SIGEF Particular:
25,58 ha $(0,7 \%)$

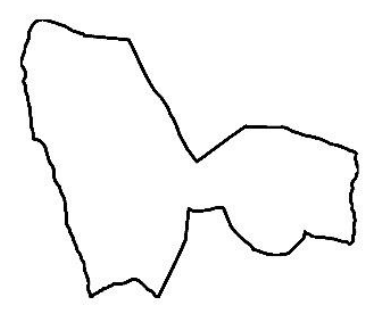

Terra Indigena: $\quad \square(0 \%)$
$0\left(\begin{array}{c}\text { Assentamento Rural: } \\ 0(0 \%)\end{array}\right.$

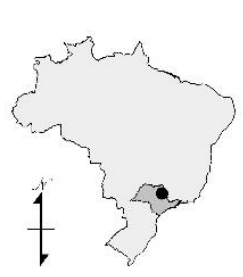

ESTACĀO ECOLÓGICA

Situaçäo Fundiária: Parcialm. regularizado Plano de Manejo: Não

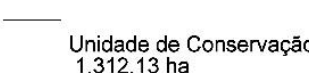
$1.312,13$ ha DE SANTA MARIA CAR dentro da UC:
29,63 ha $(2,3 \%)$
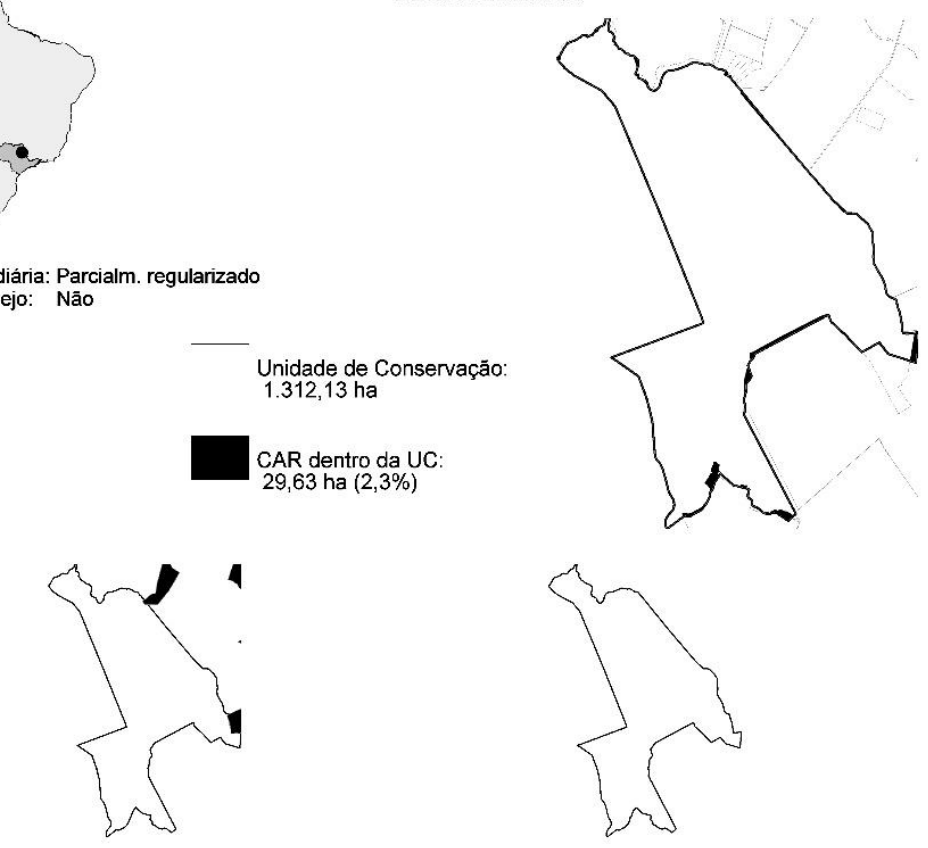

SIGEF Particular
4,05 ha $(0,3 \%)$

Terra Indigena
$0(0 \%)$ 


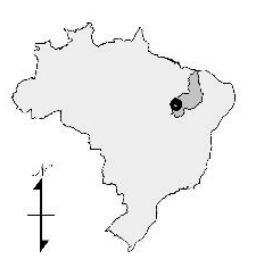

Situaçăo Fundiária: Parcialm. regularizado Plano de Manejo: Não
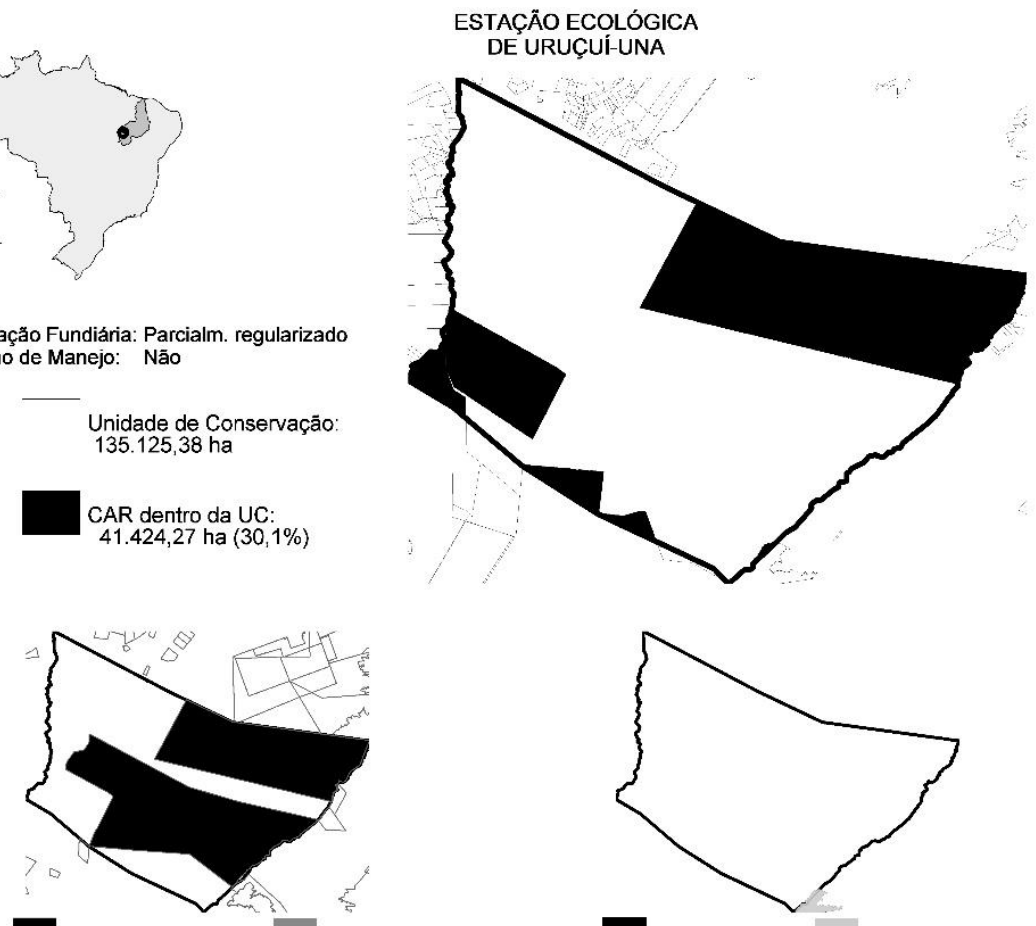

SIGEF Particular:
$73.197,52$ ha $(54,62 \%)$$\quad \begin{aligned} & \text { SIGEF Público: } \\ & 0(0 \%)\end{aligned}$
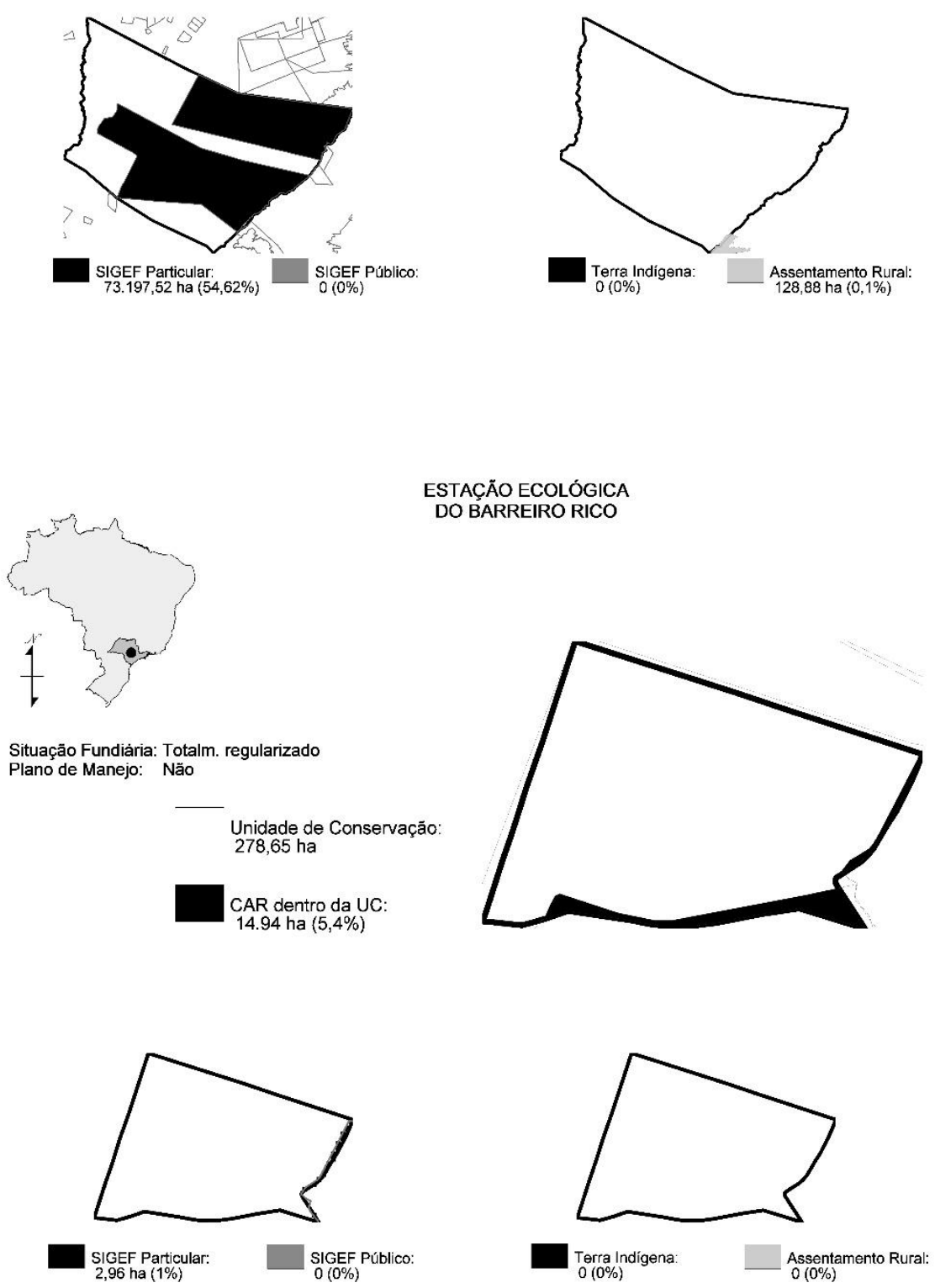


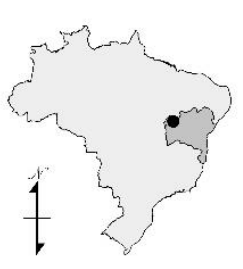

ESTAÇÃO ECOLÓGICA

DO RIO PRETO

Situação Fundiária: Plano de Manejo:

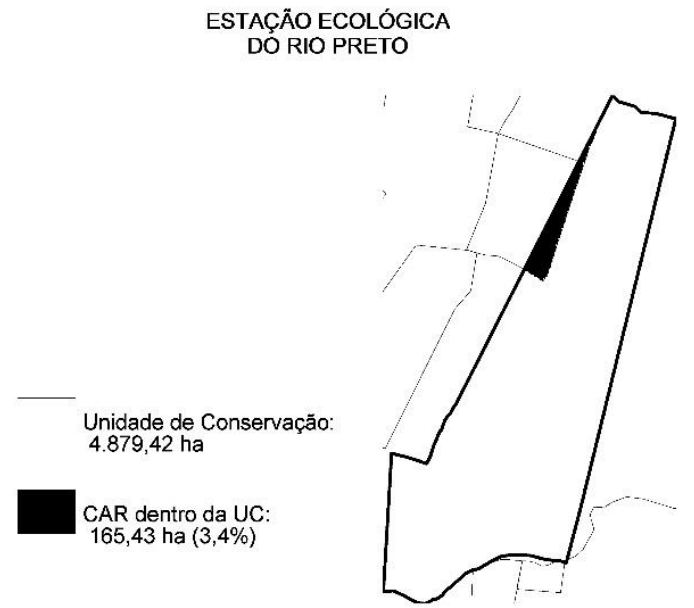

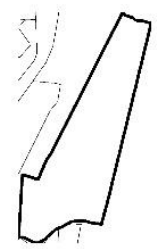

SIGEF Particular:
0,67 ha $(0,0 \%)$
SIGEF Público:
$0(0 \%)$

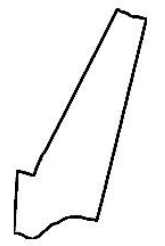

Terra Indigena:
$0(0 \%)$

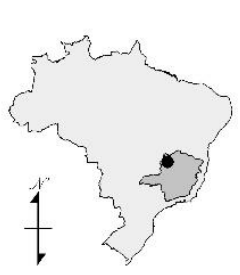

Situação Fundiària: Plano de Manejo: Näo Unidade de Conservação: 2.344, 10 ha

CAR dentro da UC: 123.92 ha $(5,2 \%)$

ESTAÇĀO ECOLÓGICA DE SAGARANA
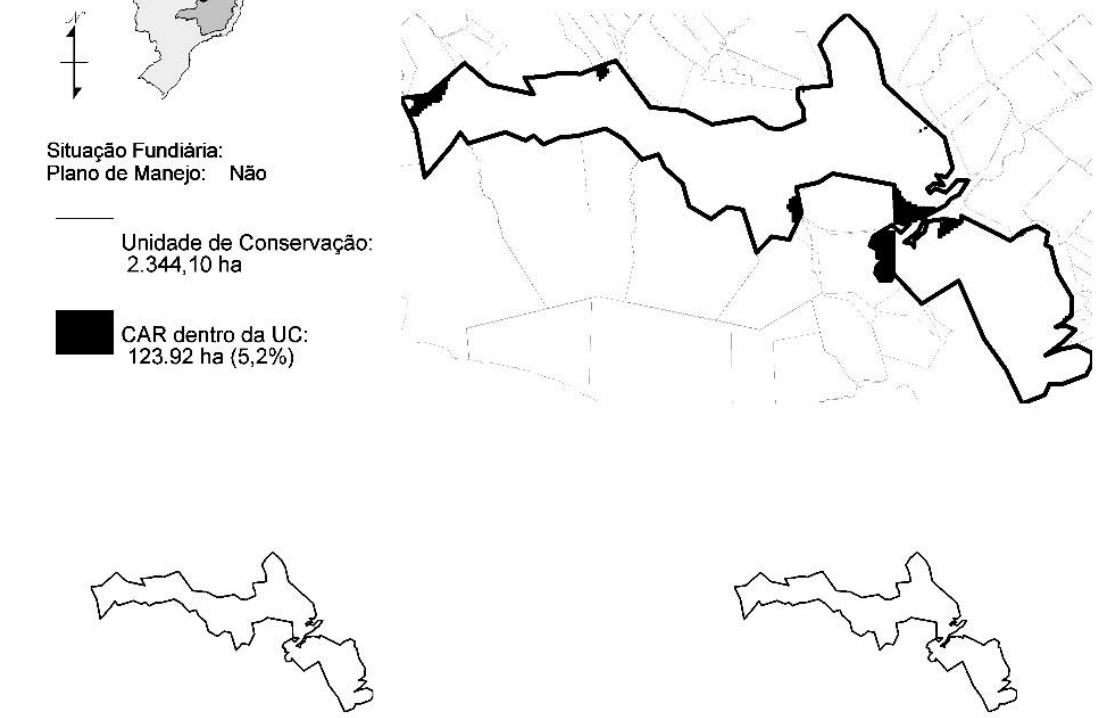

SIGEF Particular

SIGEF Público:
$0(0 \%)$

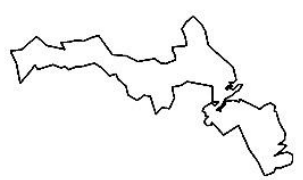

$\underset{0(0 \%)}{\text { Terra Indígena: }}$

Assentamento Rural: 


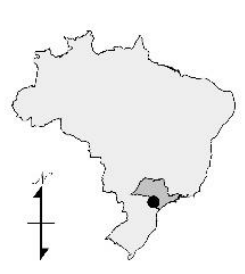

ESTAÇÄO ECOLÓGICA

Situação Fundiária: Totalm. regularizado Plano de Manejo: Nāo

DE ITABERA
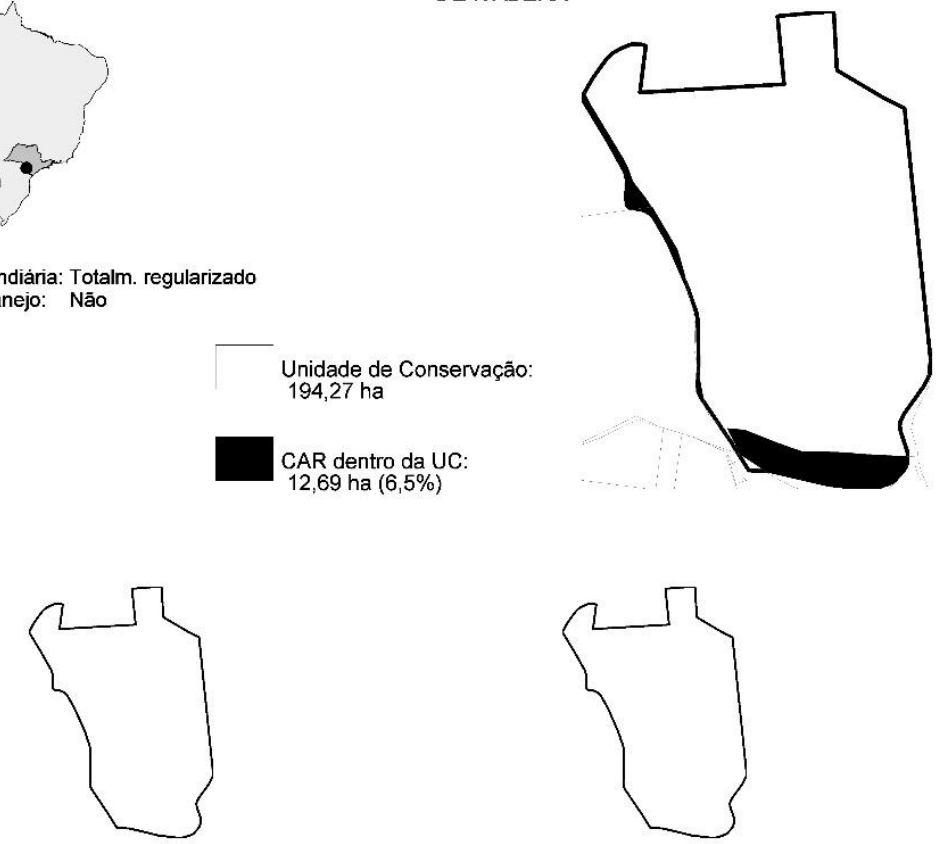

SIGEF Particular:
$0(0 \%)$

\begin{tabular}{l}
\hline SIGEF Público: \\
$0(0 \%)$
\end{tabular}

Terra Indigena:
$0(0 \%)$

Assentamento Rural:
$0(0 \%)$

ESTACĂO ECOLÓGICA

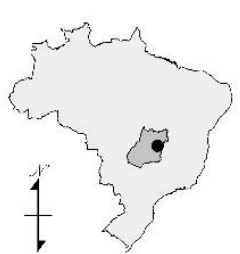

DO JARDIM BOTÂNICO DE BRASÍLIA

Situação Fundiária: Parcialm. regularizado Plano de Manejo: Năo Unidade de Conservação:
$4.502,48$ ha

CAR dentro da UC:

$1.750,84$ ha $(39,8 \%)$
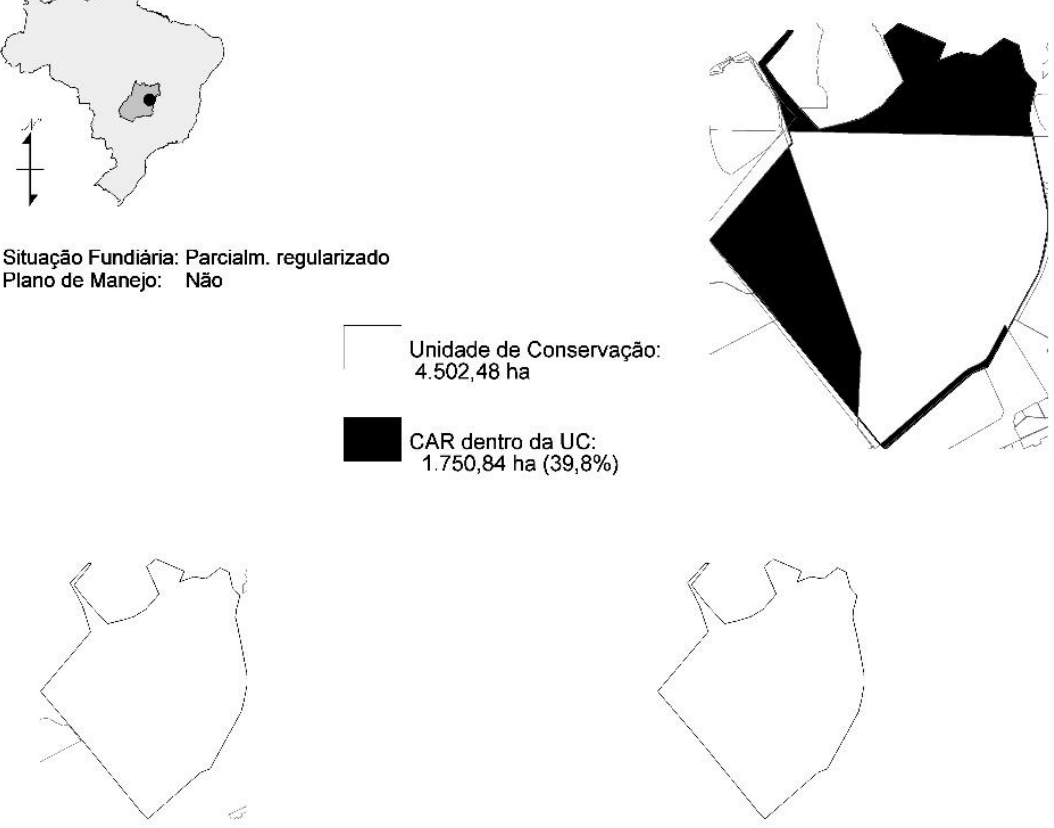

SIGEF Particular.

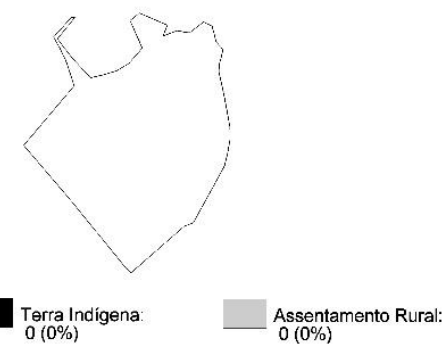




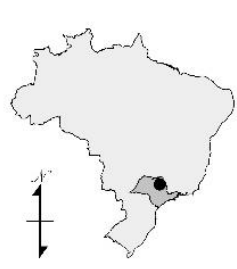

STACAO ECOLÓGICA

DA MATA DO JACARE

Situação Fundiária: Totalm. regularizado Plano de Manejo: Não

Unidade de Conservação 82,69 ha

CAR dentro da UC

1,11 ha $(1 \%)$
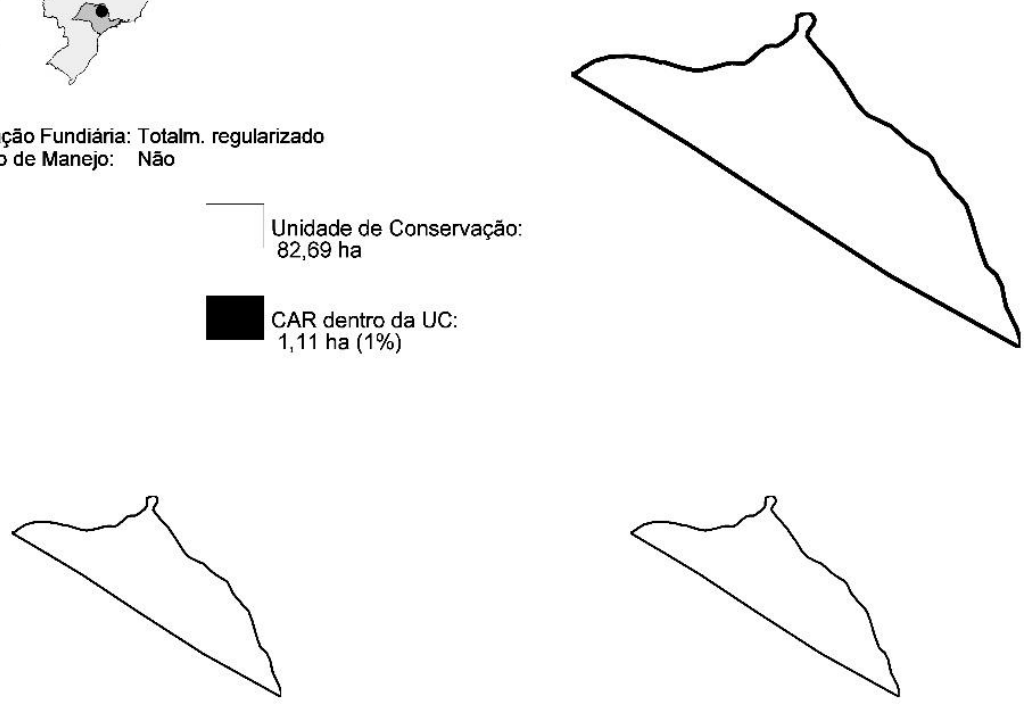

SIGEF Particular:
$0(0 \%)$

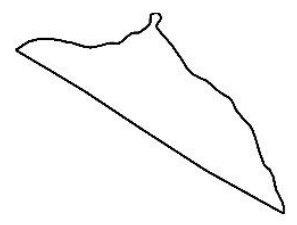

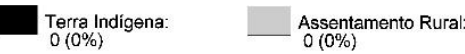

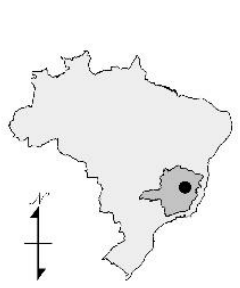

ESTAÇÄO ECOLÓGICA

Situação Fundiària: Plano de Manejo: Năo Unidade de Conservaçăo: 454,73 ha

CAR dentro da UC:

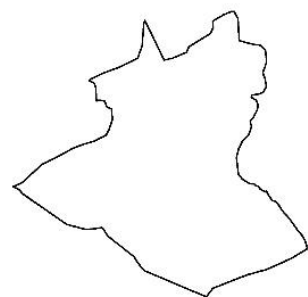

$\underset{0(0 \%)}{\text { SIGEF Particular: }}$ $\underset{0(0 \%)}{\text { SIGEF Público: }}$

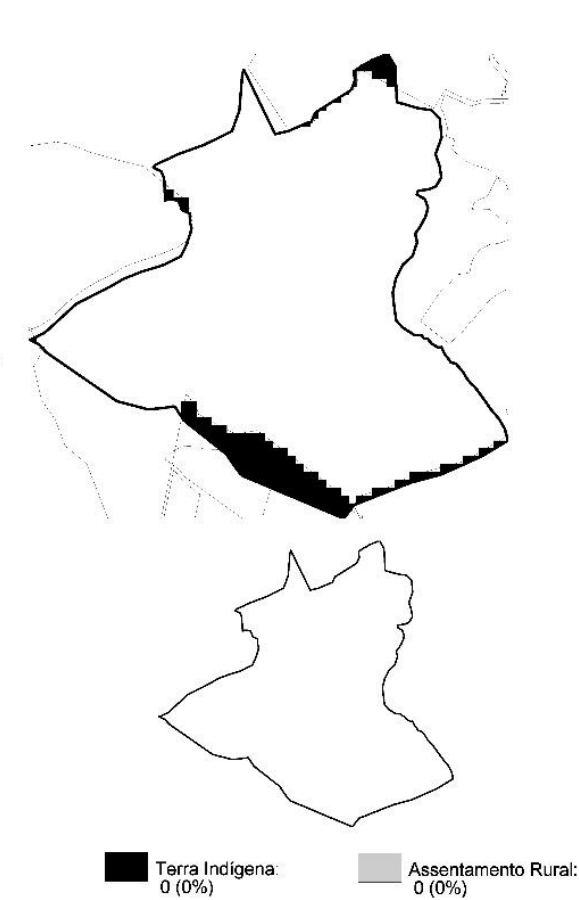




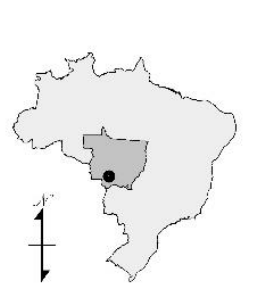

ESTAÇÃO ECOLÓGICA

DA SERRA DAS ARARAS

Situaçăo Fundiária: Totalm. regularizado Plano de Manejo: Sim
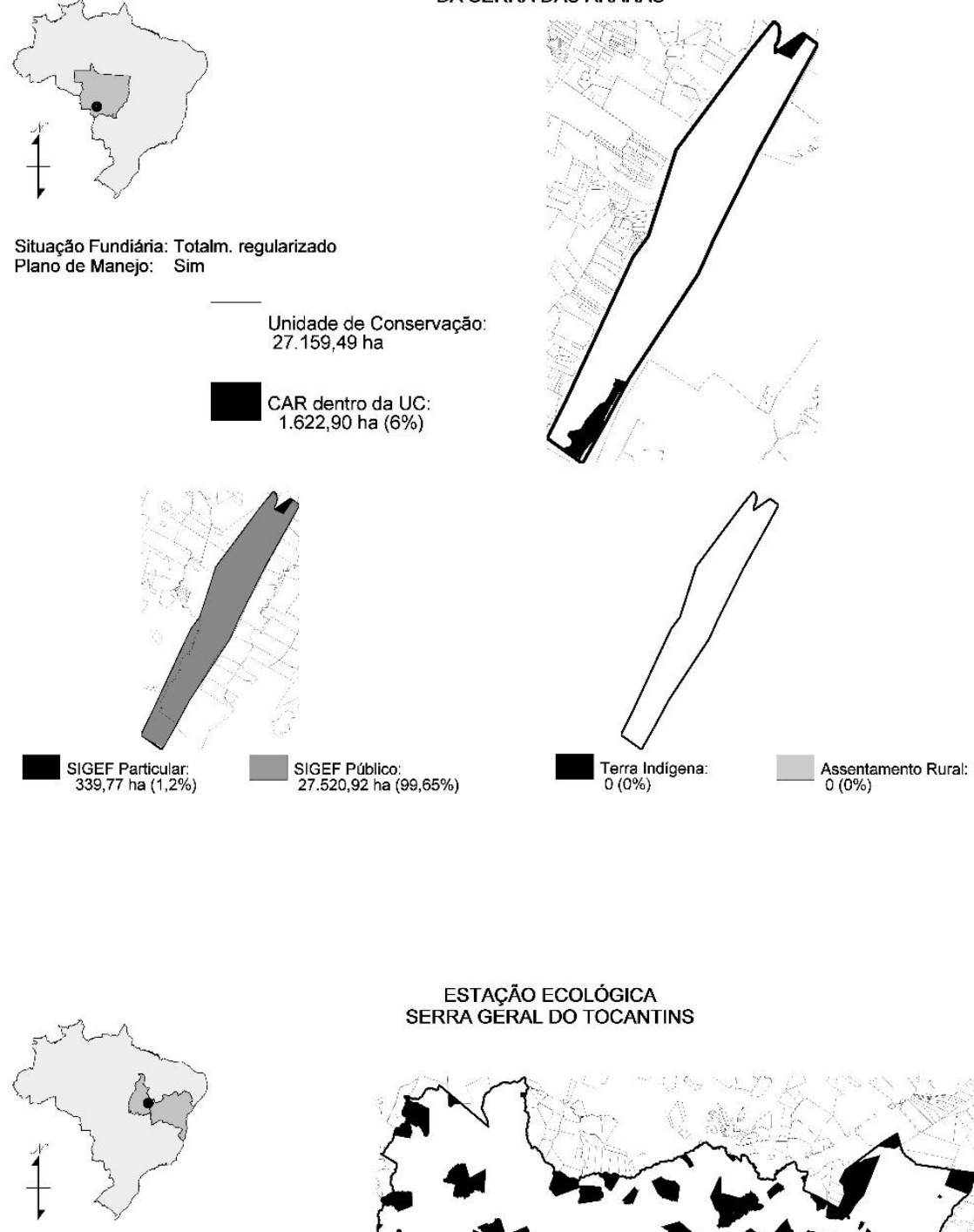

Situação Fundiảria: Parcialm. regularizado Plano de Manejo: Sim

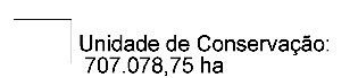
$707.078,75$ ha

CAR dentro da UC:

$130.044,38$ ha $(18,4 \%)$

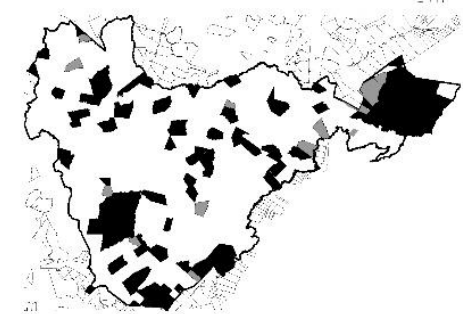

\begin{tabular}{l|l} 
SIGEF Particular: & SIGEF Público: \\
183.245,89 ha (25.98\%) & 19.566 ha $(2,8 \%)$
\end{tabular}

ESTAÇÄO ECOLÓGICA SERRA GERAL DO TOCANTINS
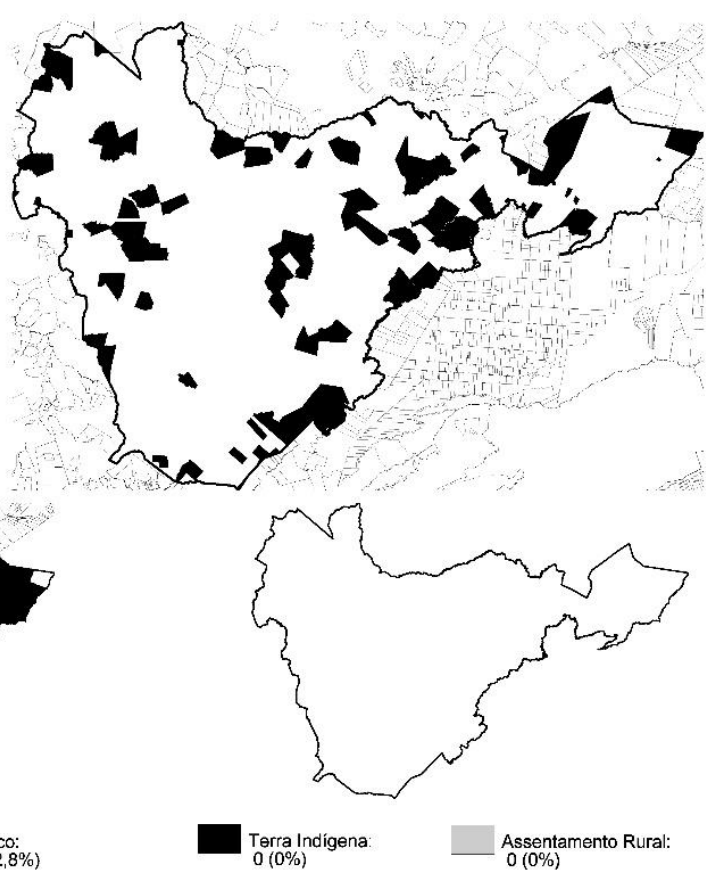
ANEXO 2 - Mapas das florestas nacionais do bioma Cerrado

\begin{tabular}{|c|c|c|c|}
\hline Floresta Nacional da Mata Grande & GO & Flona & Federal \\
\hline Floresta Nacional de Brasília & DF/GO & Flona & Federal \\
\hline Floresta Nacional de Capão Bonito & SP & Flona & Federal \\
\hline Floresta Nacional de Cristópolis & BA & Flona & Federal \\
\hline Floresta Nacional de Paraopeba & MG & Flona & Federal \\
\hline Floresta Nacional de Silvânia & GO & Flona & Federal \\
\hline Floresta Nacional dos Palmares & PI & Flona & Federal \\
\hline
\end{tabular}



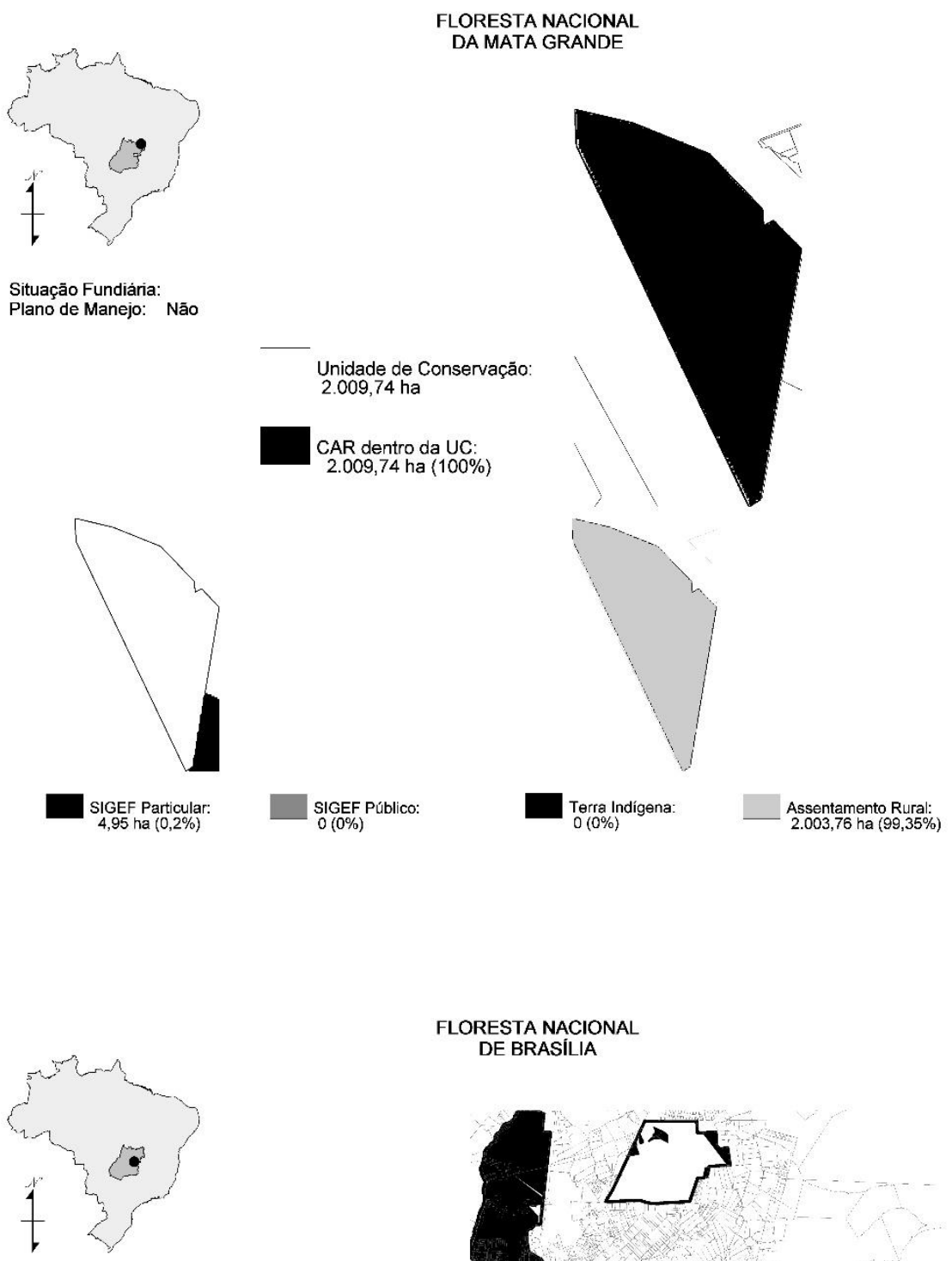

FLORESTA NACIONAL

DE BRASÍLIA

Situação Fundiảria:

Plano de Manejo: Sim

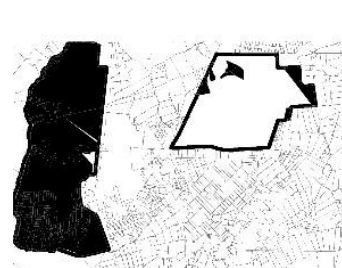
Unidade de Conservação:
$9.336,17 \mathrm{ha}$

CAR dentro da UC:
$7.608,95$ ha $(81,5 \%)$

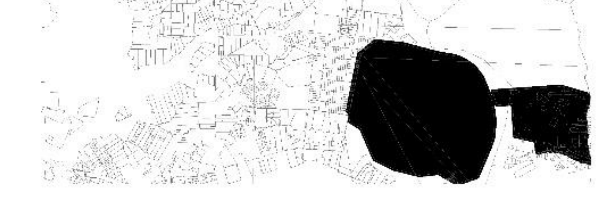

$\left\{c^{3}\right.$

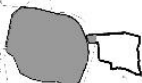

SIGEF Particular:
5,45 ha $(0,17 \%)$
SIGEF Público:
3.445,73 ha $(78,24 \%)$
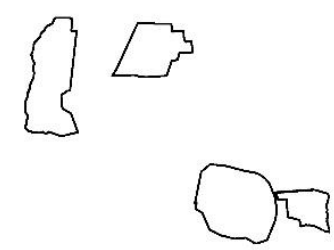

Terra Indigena
$0(0 \%)$

Assentamento Rural:
$0(0 \%)$ 

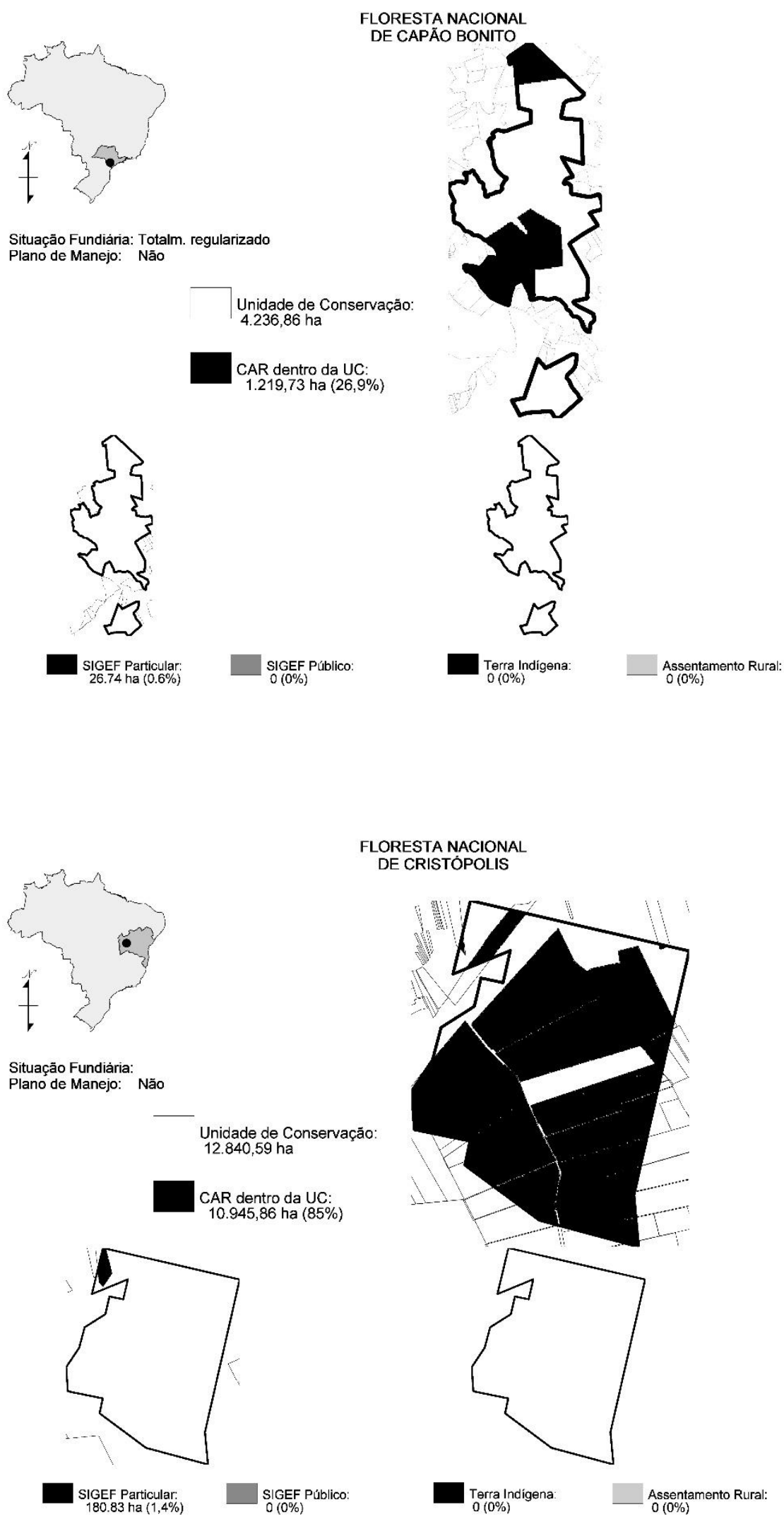

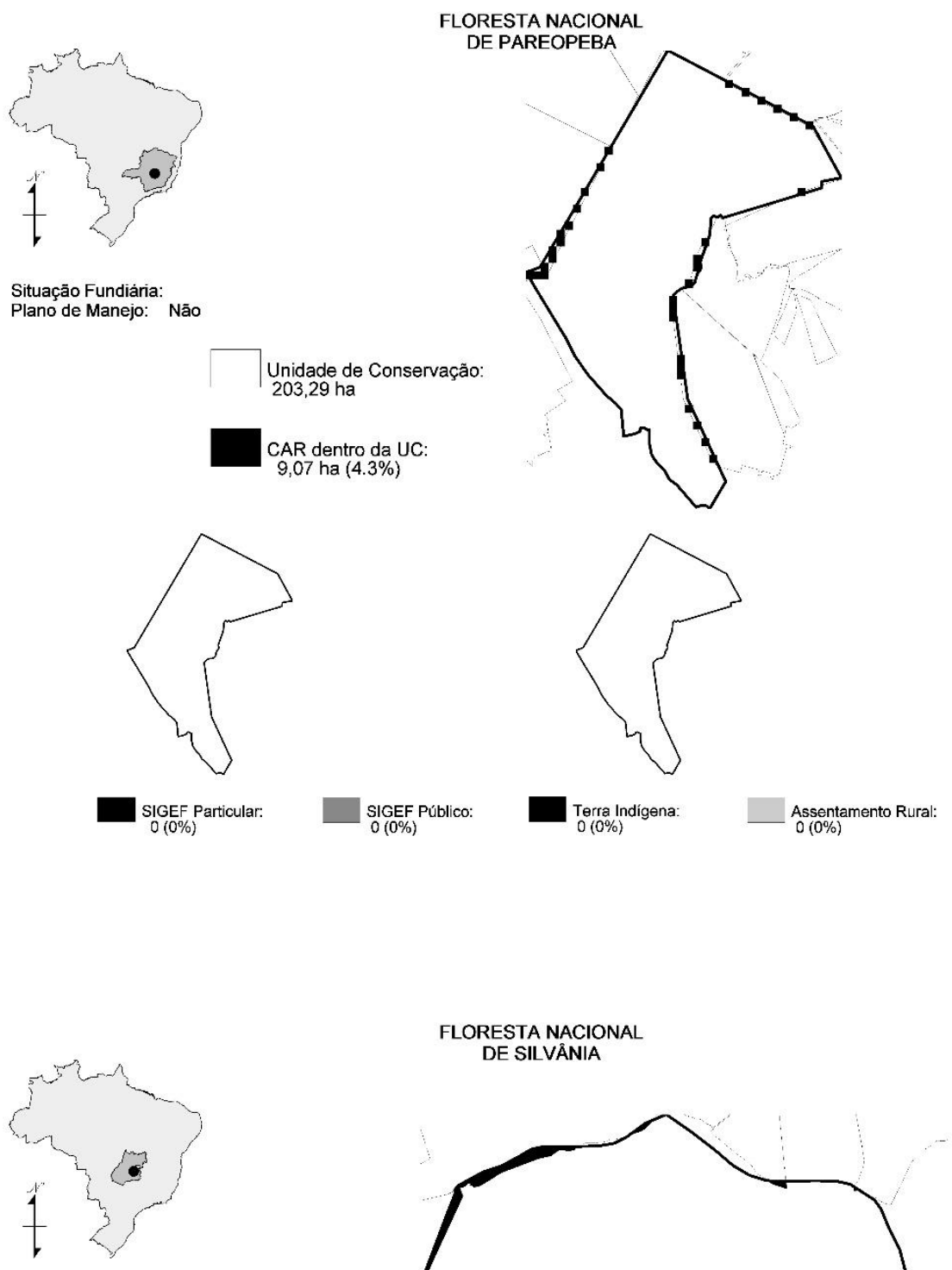

Situação Fundiária: Totalm. regularizado Plano de Manejo: Năo

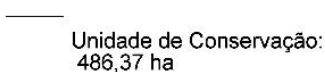
486,37 ha

CAR dentro da UC

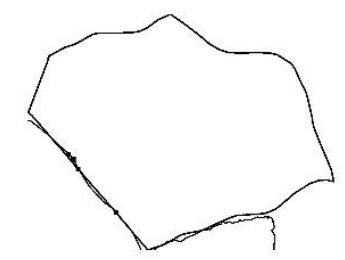

SIGEF Particular:
1,56 ha $(0,3 \%)$

$\underset{0(0 \%)}{\text { SIGEF Público: }}$

FLORESTA NACIONAL

DE SILVÂNIA
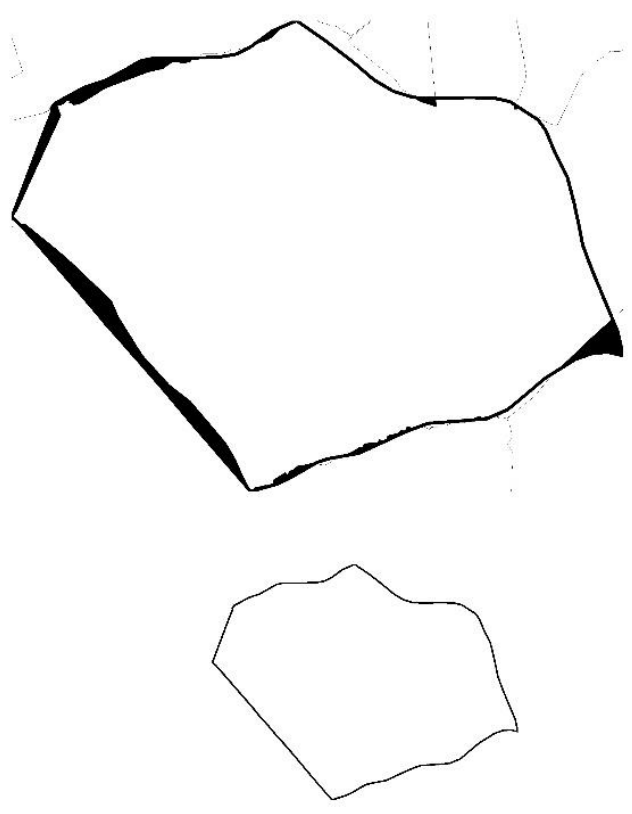

Terra Indigena: $\quad$ Assentamento Rural:
$0(0 \%)$
$0(0 \%)$ 
214

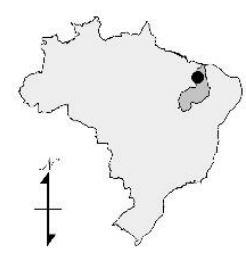

Situação Fundiária:
Plano de Manejo: Não

FLORESTA NACIONAL

DE PALMARES

Unidade de Conservação

CAR dentro da UC:
$0(0 \%)$
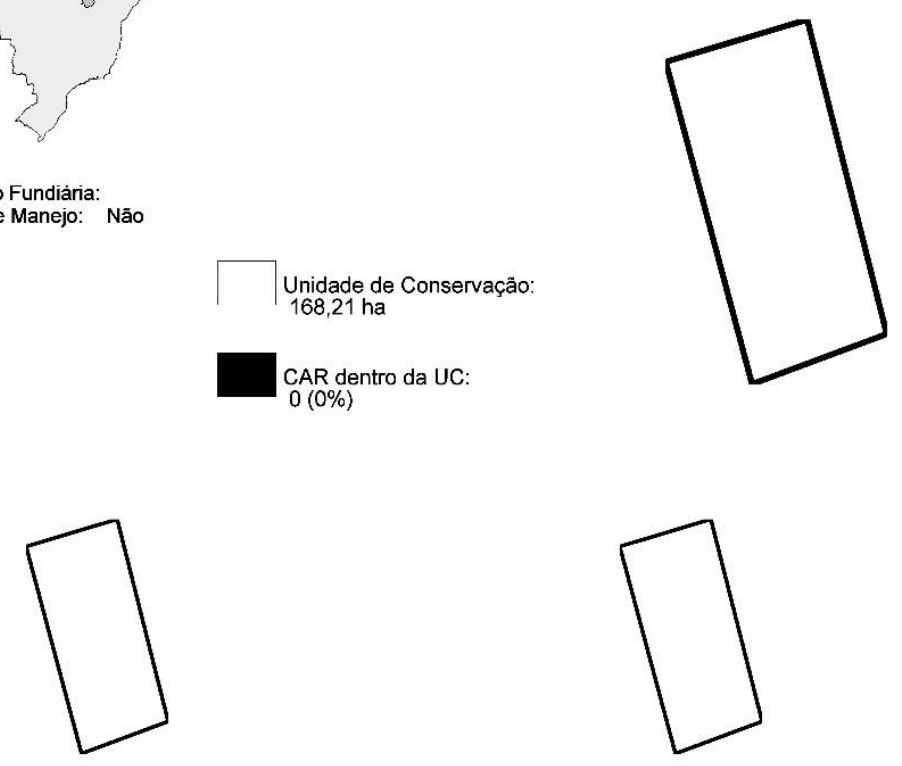

SIGEF Particular:
$0(0 \%)$

Terra Indigena:
$0(0 \%)$

Assentamento Rural: 
ANEXO 3 - Mapas dos parques nacionais do bioma Cerrado

\begin{tabular}{|c|c|c|c|}
\hline Parque Nacional Cavernas de Peruaçu & MG & Parna & Federal \\
\hline Parque Nacional da Chapada das Mesas & MA & Parna & Federal \\
\hline Parque Nacional da Chapada dos Guimarães & MT & Parna & Federal \\
\hline Parque Nacional da Chapada dos Veadeiros & GO & Parna & Federal \\
\hline Parque Nacional da Serra da Bodoquena & MS & Parna & Federal \\
\hline Parque Nacional da Serra da Canastra & MG & Parna & Federal \\
\hline Parque Nacional da Serra das Confusões & PI & Parna & Federal \\
\hline Parque Nacional da Serra do Cipó & MG & Parna & Federal \\
\hline Parque Nacional das Emas & GO & Parna & Federal \\
\hline Parque Nacional das Sempre-Vivas & MG & Parna & Federal \\
\hline Parque Nacional de Araguaia & TO & Parna & Federal \\
\hline Parque Nacional de Brasília & $\mathrm{DF} / \mathrm{GO}$ & Parna & Federal \\
\hline Parque Nacional dos Lençóis Maranhenses & MA & Parna & Federal \\
\hline Parque Nacional Grande Sertão Veredas & MG & Parna & Federal \\
\hline Parque Nacional Nascentes do Rio Parnaíba & $\mathrm{BA} / \mathrm{TO} / \mathrm{MA} / \mathrm{PI}$ & Parna & Federal \\
\hline
\end{tabular}



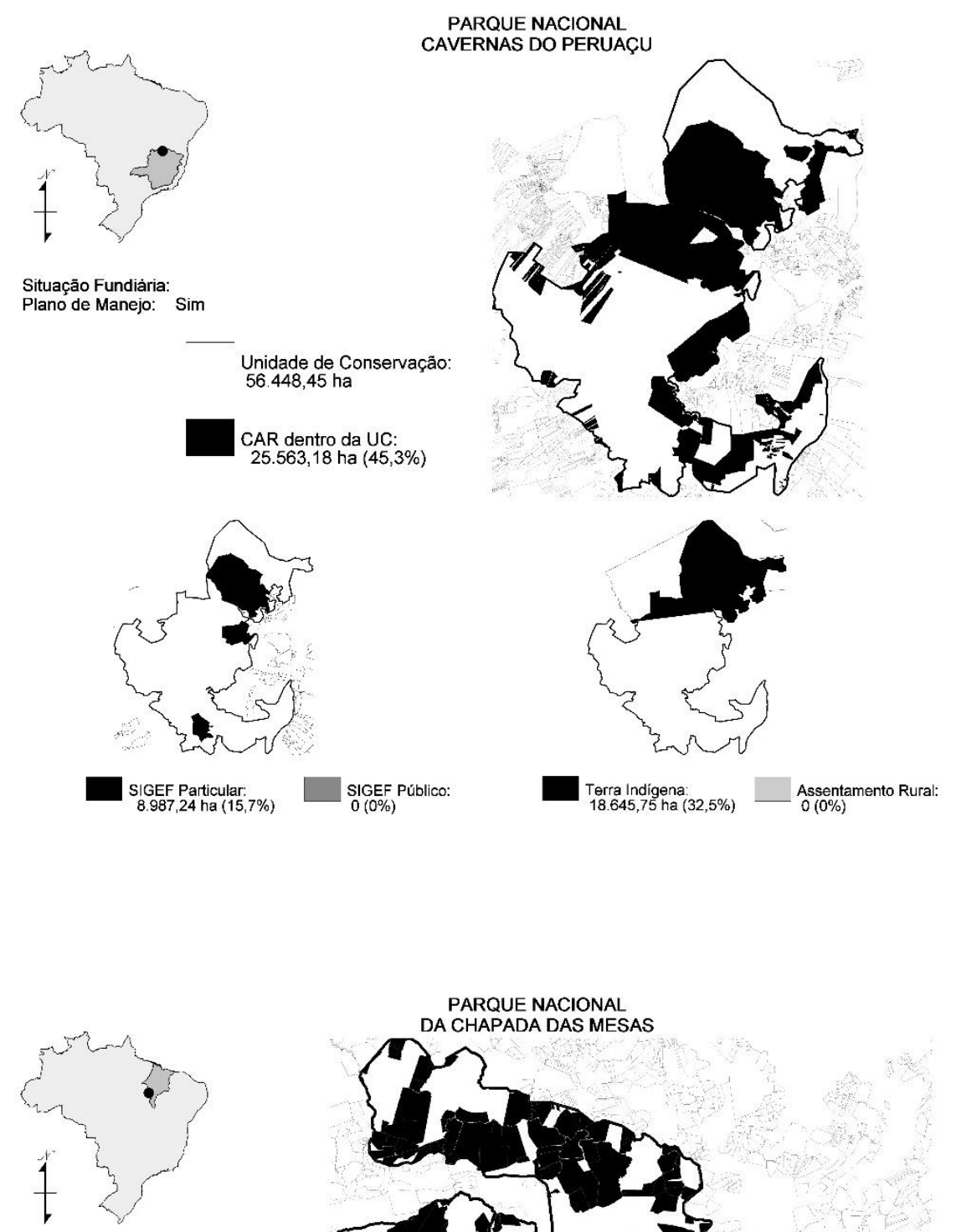

Situação Fundiária: Não regularizado Plano de Manejo: Nāo

Unidade de Conservação:
$159.952,26$ ha

CAR dentro da UC:
$68.663,3$ ha $(42,9 \%)$

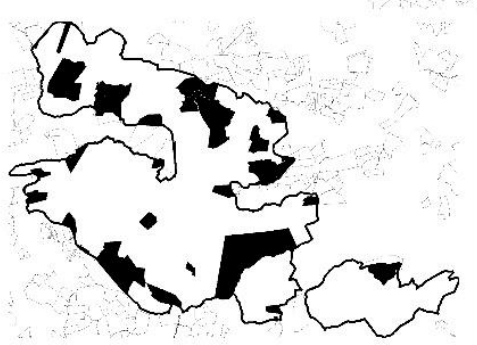

PARQUE NACIONAL

DA CHAPADA DAS MESAS

SIGEF Particular:
$31.875,59$ ha $(20,18 \%)$

$\underset{0}{\text { SIGEF Público }}$
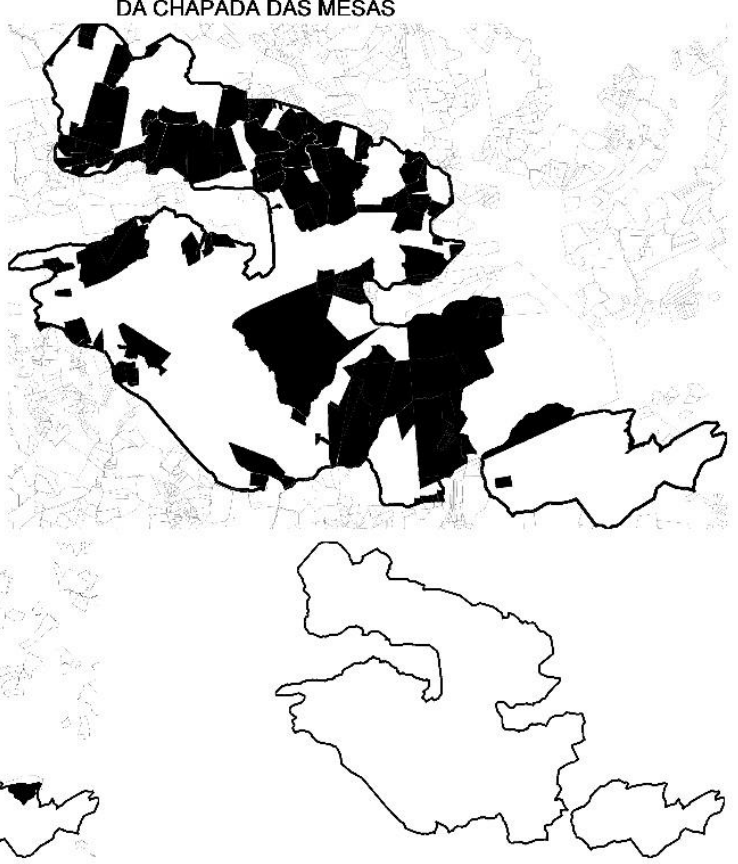

$\underset{0}{T}(0 \%)$

Assentam
$0(0 \%)$ 


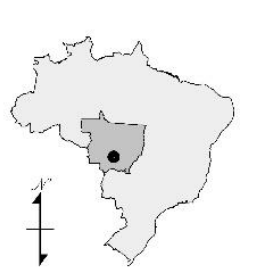

PARQUE NACIONAL

DA CHAPADA DOS GUIMARÃES

Situaçăo Fundiária: Parcialm. regularizado Plano de Manejo: Sim

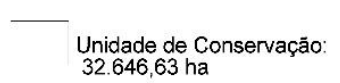
$32.646,63$ ha

\section{CAR dentro da UC:
$7.860,75$ ha $(24,1 \%)$}

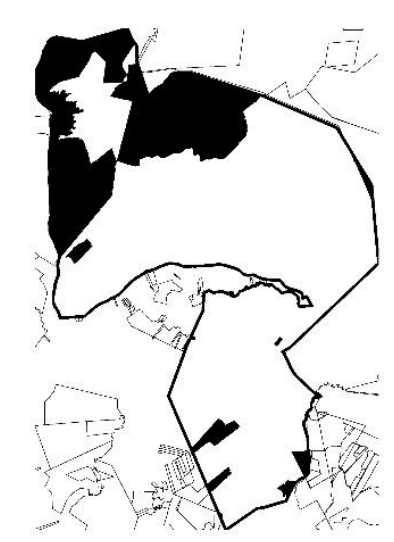

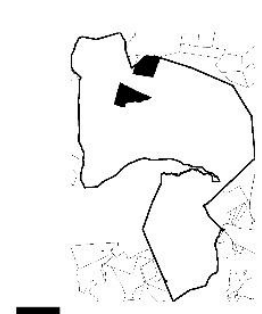

SIGEF Particular:
$1.104,91$ ha $(3,3 \%)$

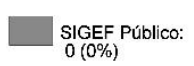

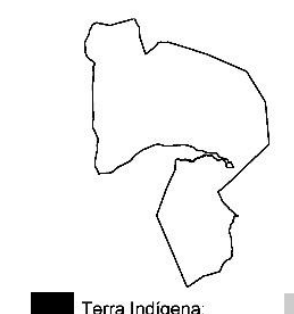

Terra Indígena
$0(0 \%)$

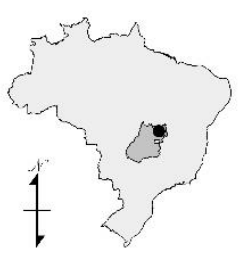

Situação Fundiária: Parcialm. regularizado Plano de Manejo: Não

Unidade de Conservação: $249.008,77$ ha

CAR dentro da UC:
$128.367,08$ ha $(51,6 \%)$
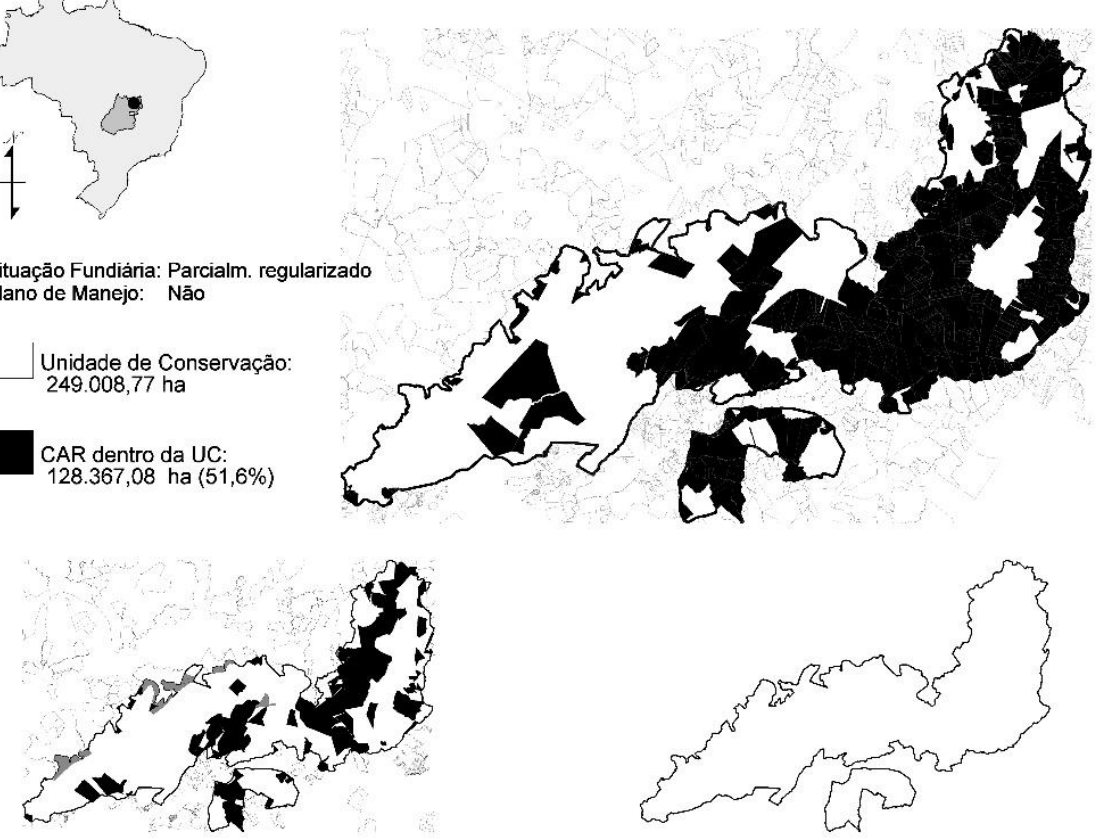

SIGEF Particular:
$75.358,08$ ha $(30,3 \%)$

SIGEF Público:

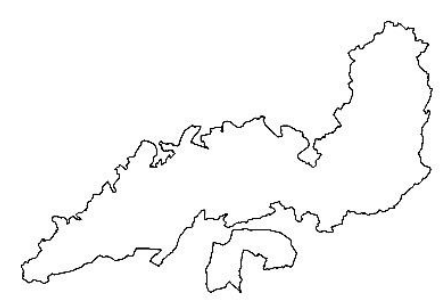

Assenta
$0(0 \%)$ 

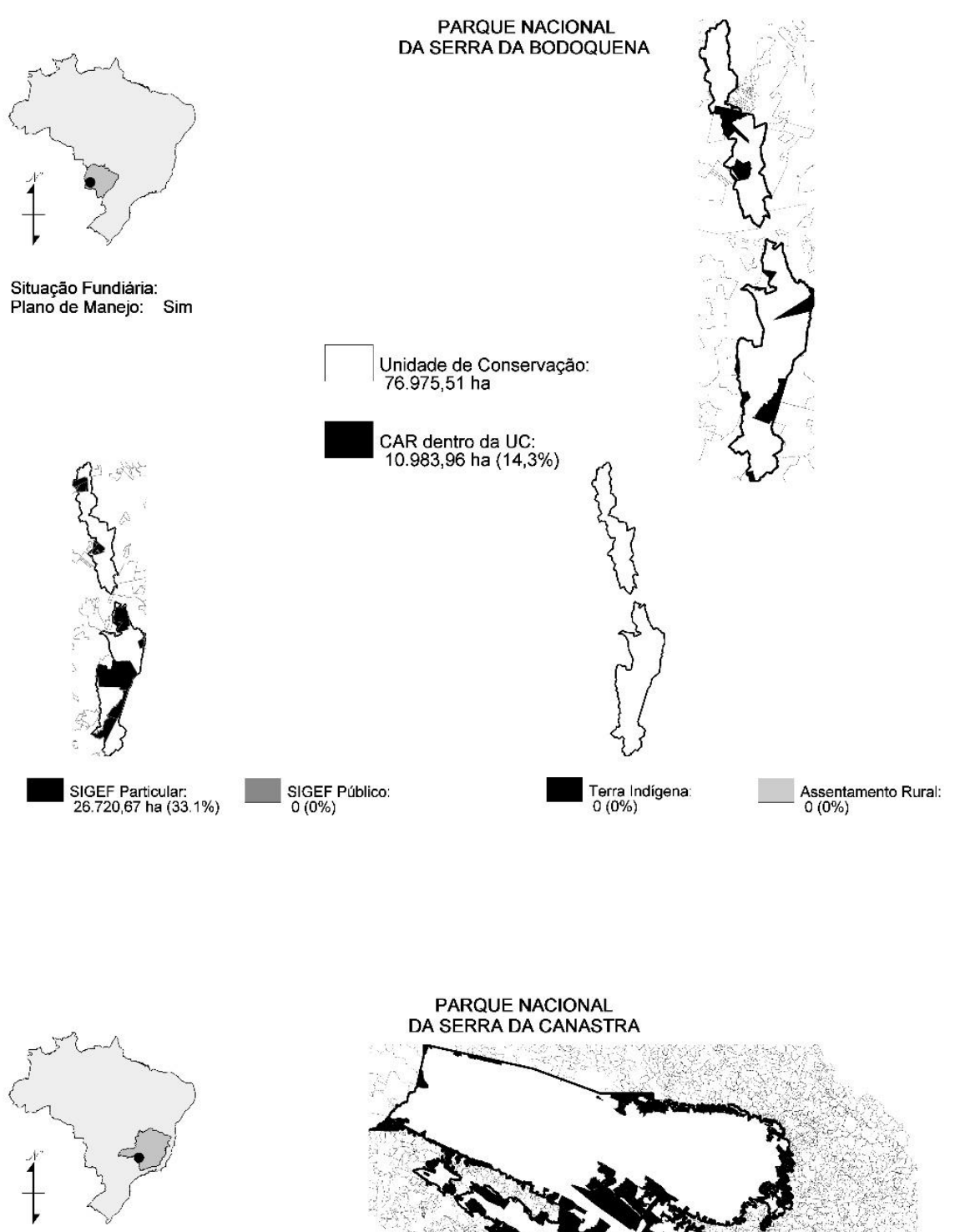

Situação Fundiária: Parcialm. regularizado Plano de Manejo: Sim Unidade de Conservaçăo:
$197.813,5$ ha

CAR dentro da UC $76.547,43$ ha $(38,7 \%)$

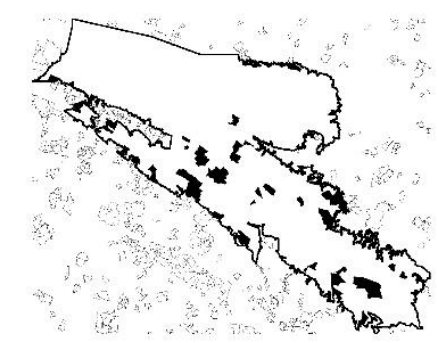

PARQUE NACIONAL DA SERRA DA CANASTRA

Situação Fundiäria:
Plano de Manejo: Sim

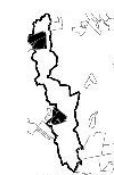

CAR dentro da UC:

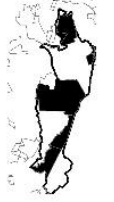

Terra Indigen
$(0 \%)$

${ }_{0}(0 \%)$
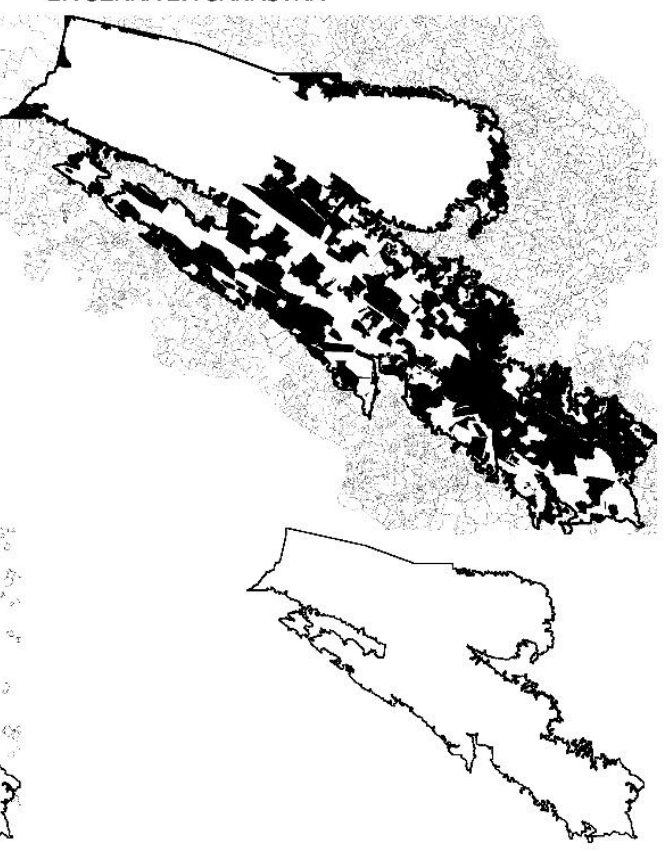

SIGEF Particular:
$13.365,28$ ha $(6,47 \%)$

Terra Indigena
$0(0 \%)$

Assenta
$0(0 \%)$ 


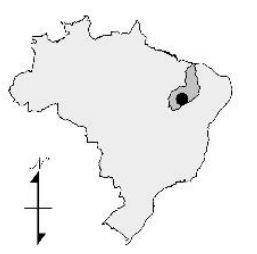

PARQUE NACIONAL

DA SERRA DAS CONFUSŌES

Situação Fundiảria: Parcialm. reguralizado Plano de Manejo: Sim

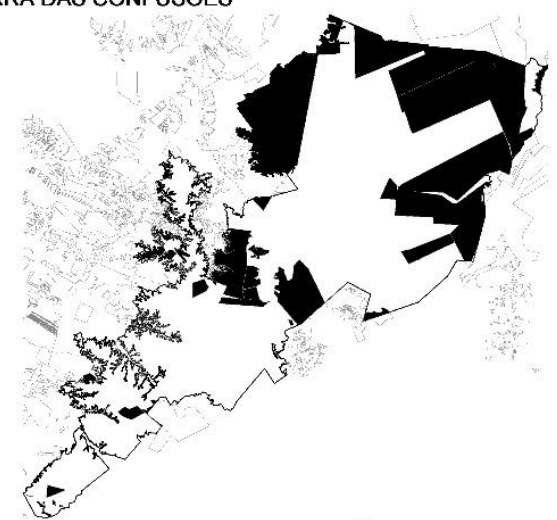

$268.763,21$ ha $(32,9 \%)$
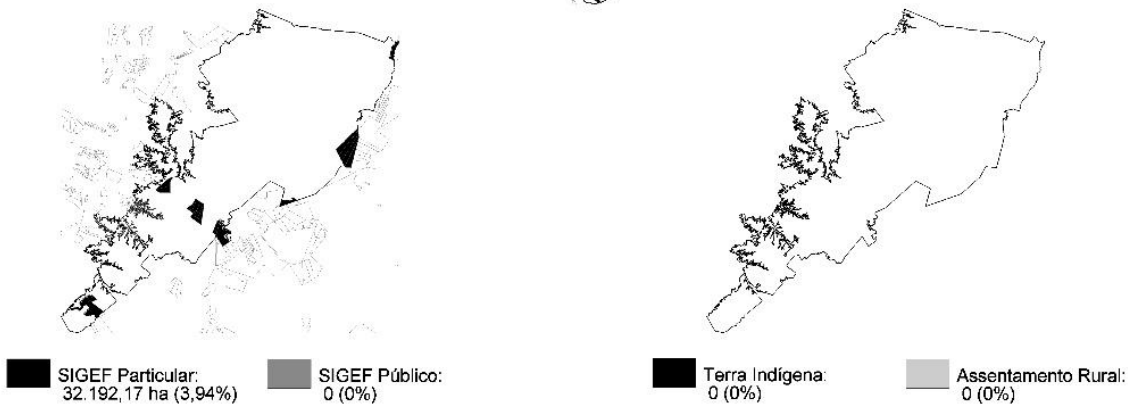

SIGEF Particular:
$32.192,17$ ha $(3,94 \%)$

Terra Indigena: $\quad$ Assentam
$0(0 \%)$

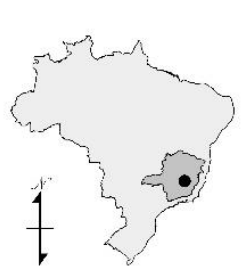

PARQUE NACIONAL

DA SERRA DO CIPÓ Situação Fundiária:
Plano de Manejo: Não
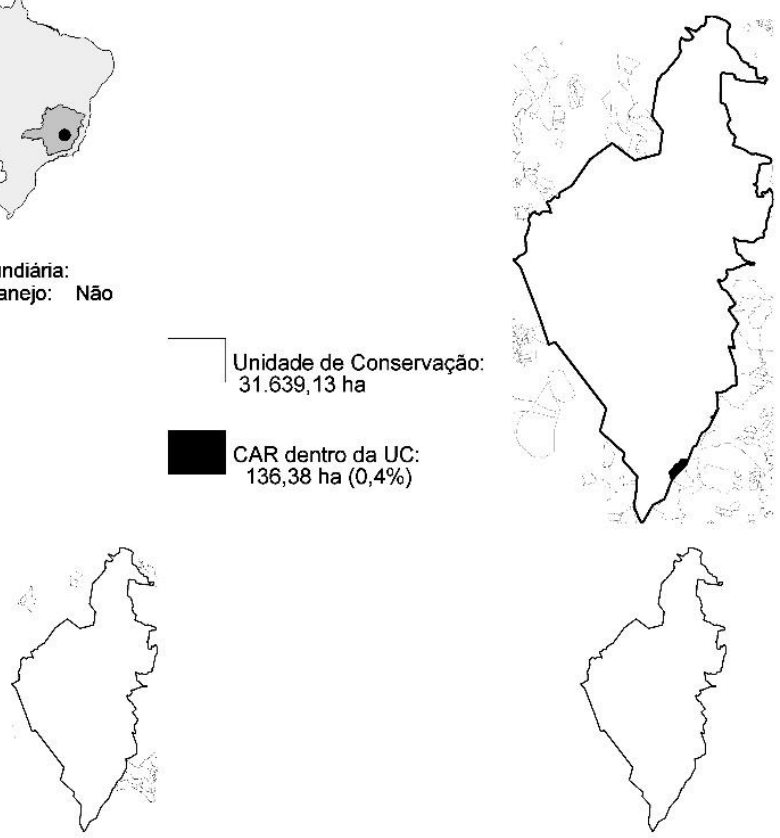

SIGEF Particular
16,62 ha $(0,5 \%)$

SIGEF Público

Terra Indigen

Assentamento Rural: 

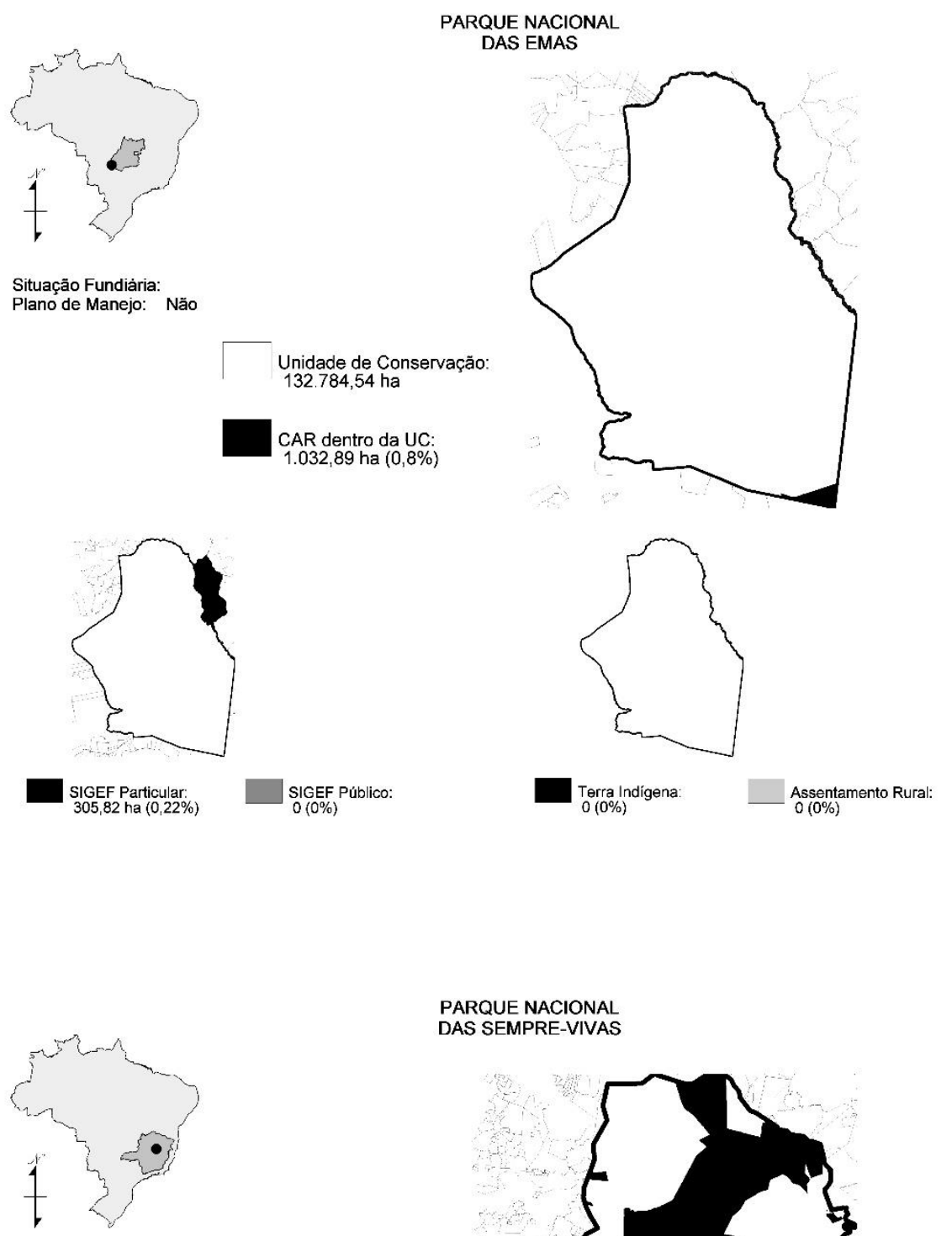

PARQUE NACIONAL

DAS SEMPRE-VIVAS

Situação Fundiária: Não regularizado Plano de Manejo: Sim

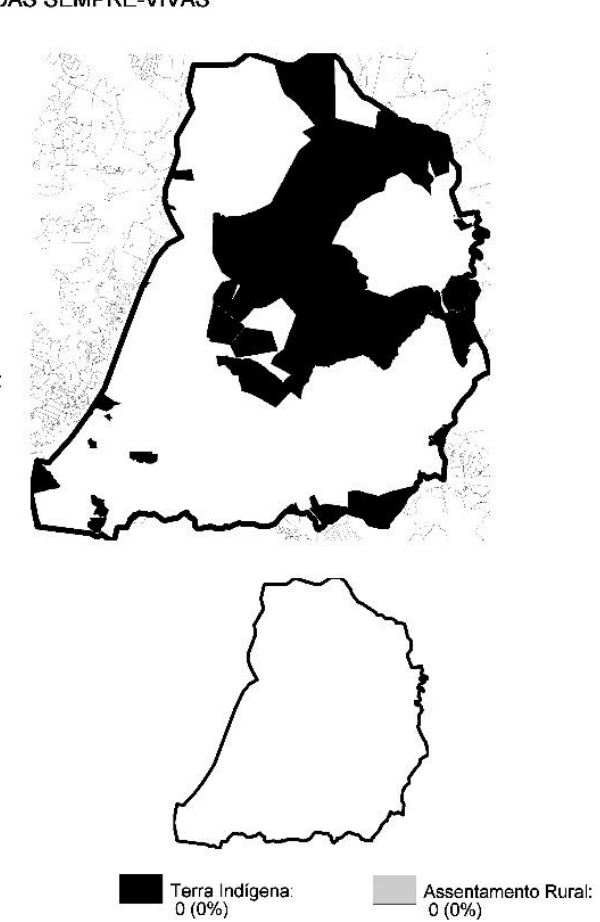


221

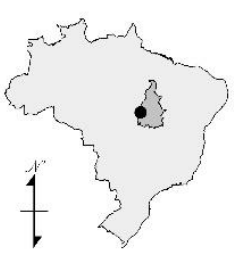

Situação Fundiária:
Plano de Manejo: Sim
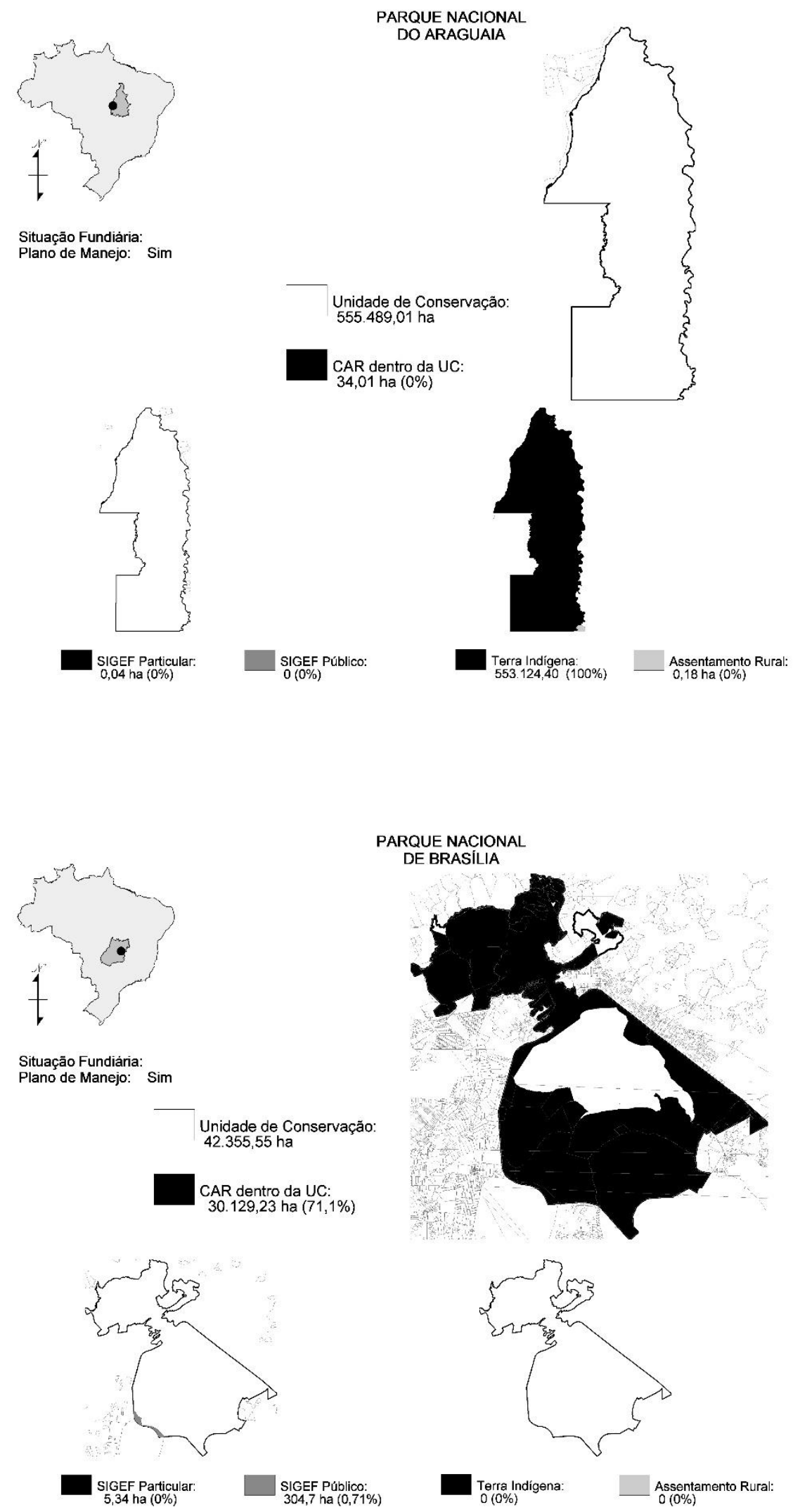


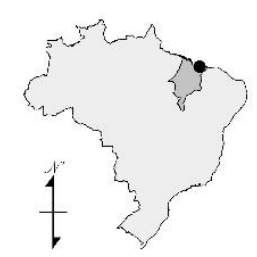

PARQUE NACIONAL

DOS LENÇÓIS MARANHENSES

\section{Situação Fundiària:}

Plano de Manejo: Năo Unidade de Conservaçăo:
$156.561,89$ ha

CAR dentro da UC: $1.344,23$ ha $(0,9 \%)$
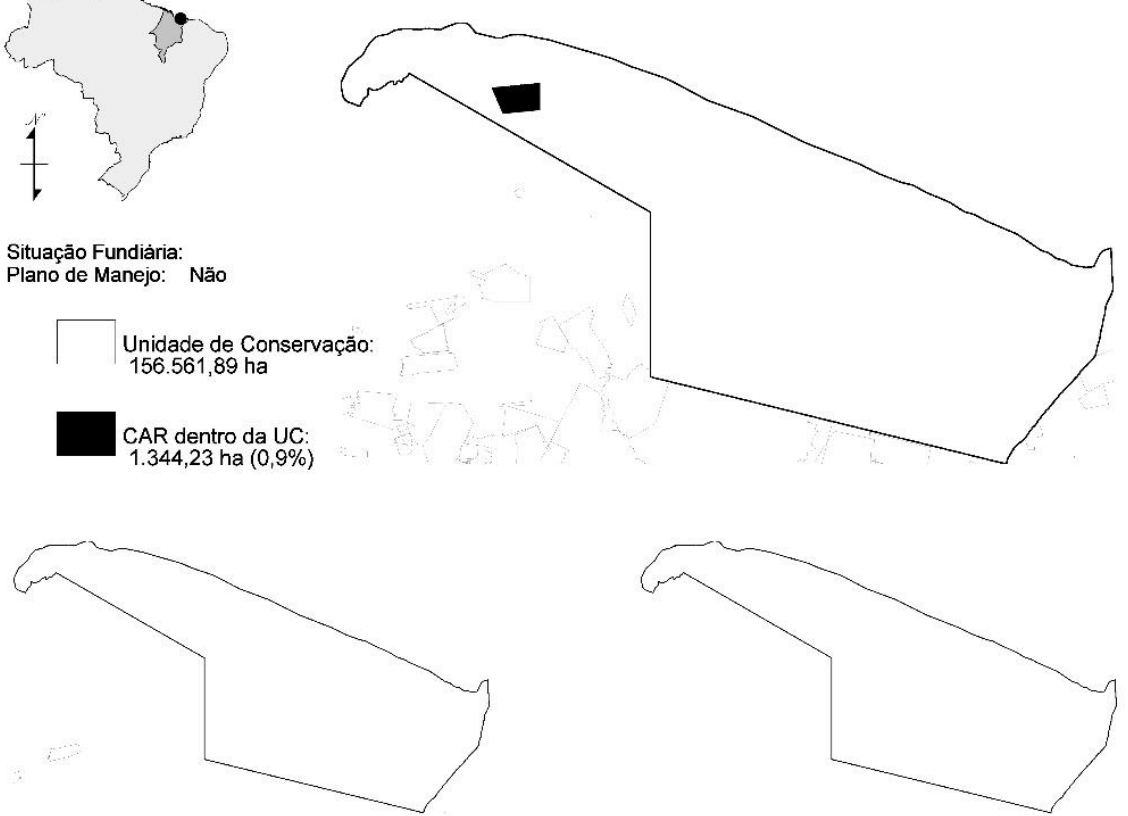

SIGEF Particular:
$0(0 \%)$$\quad$ SIGEF Público:

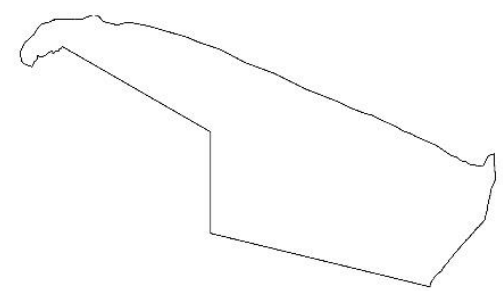

Terra Indígena:
$0(0 \%)$

Assentamento Rural:
$0(0 \%)$

PARQUE NACIONAL

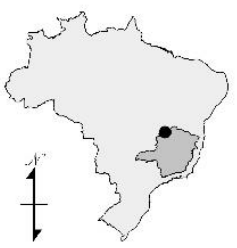

GRANDE SERTÃO VEREDAS

Situação Fundiária: Parcialm. regularizado Plano de Manejo: Sim
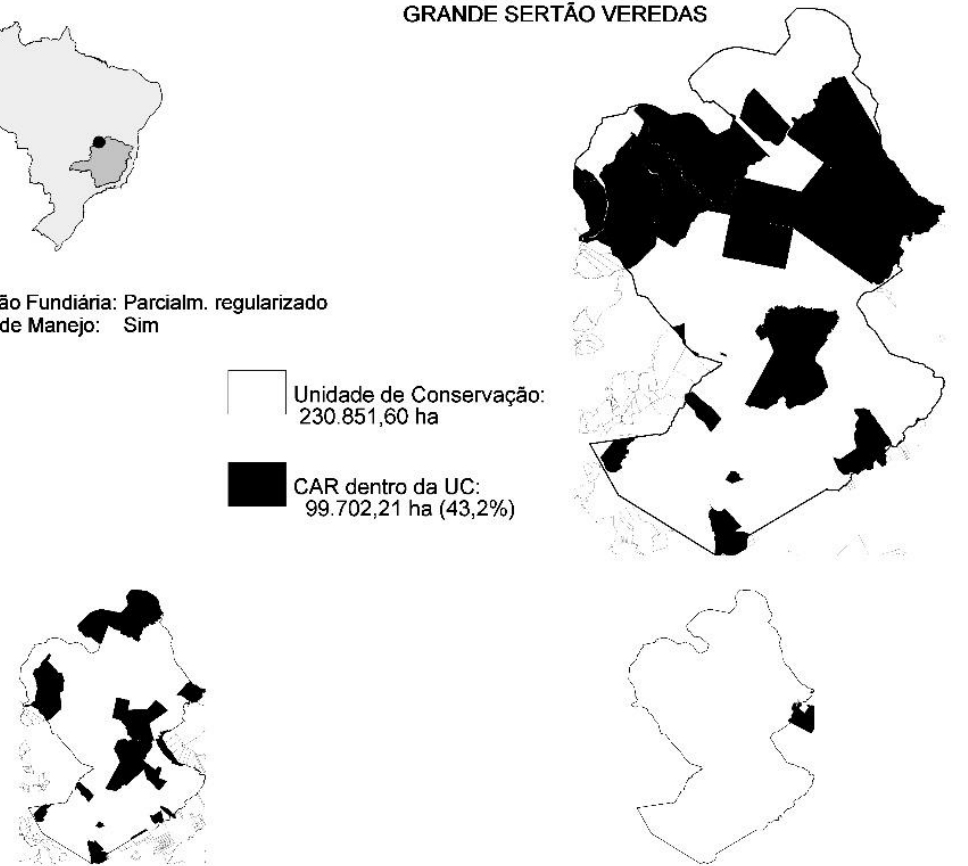

SIGEF Particular:
$62.212,72$ ha $(26.57 \%)$

nidade de Conservação: $230.851,60$ ha

CAR dentro da UC: $99.702,21$ ha $(43,2 \%)$

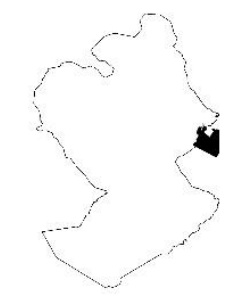

Terra Indigena: $\quad$ Assentamento Rural:
$0(0 \%)$ 


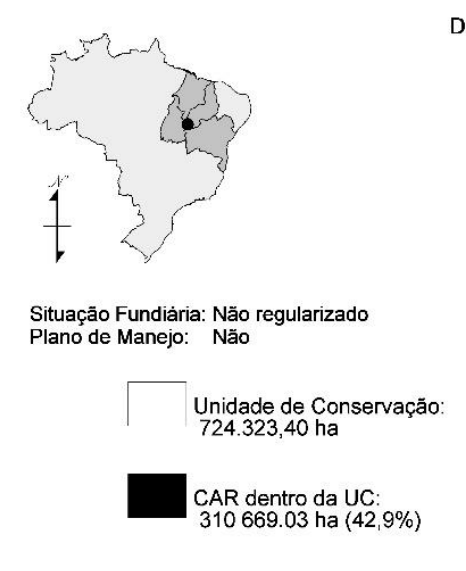

PARQUE NACIONAL
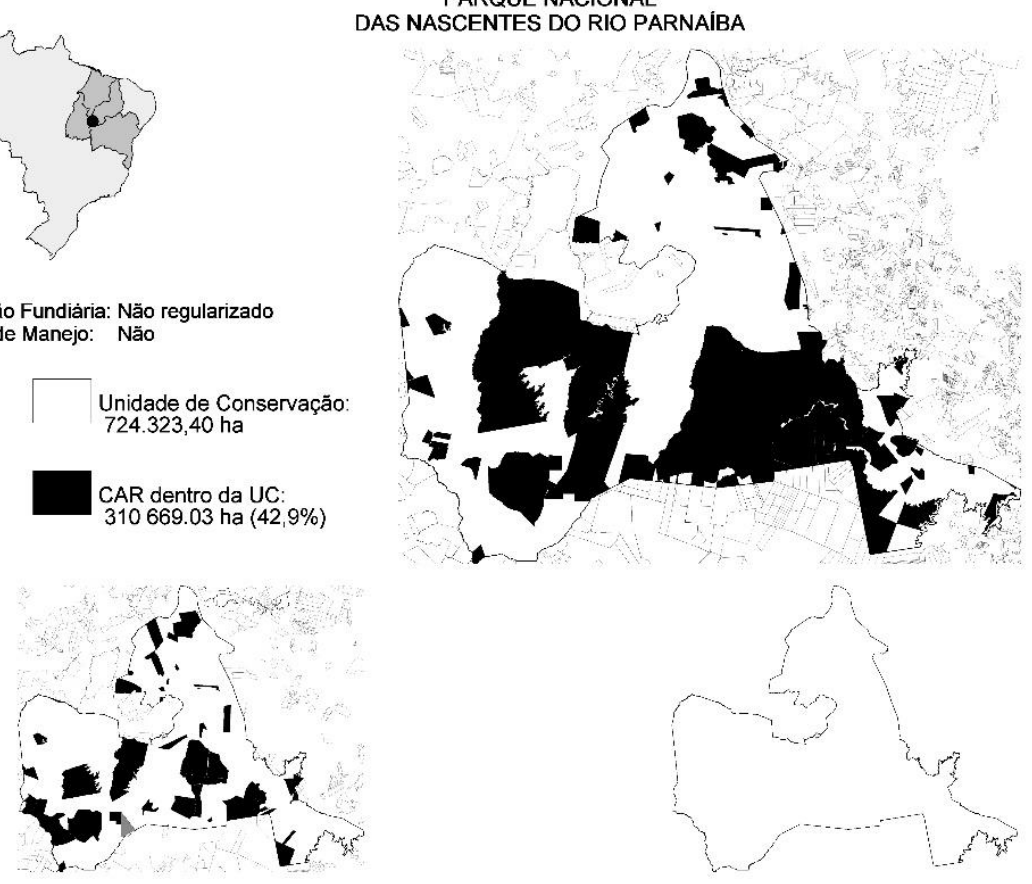

SIGEF Particular:
$175.944,13$ ha $(24,42 \%)$
SIGEF Público:
$3.157,26$ ha $(0,44 \%)$

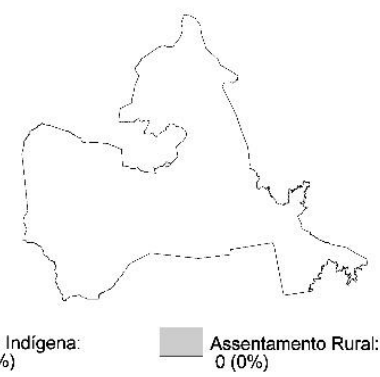


ANEXO 4 - Mapas das reservas biológicas do bioma Cerrado

\begin{tabular}{|c|c|c|c|}
\hline Reserva Biológica da Contagem & DF & Rebio & Federal \\
\hline Reserva Biológica de Culuene & MT & Rebio & Estadual \\
\hline Reserva Biológica do Cerradão & DF & Rebio & Estadual \\
\hline Reserva Biológica do Gama & DF & Rebio & Estadual \\
\hline Reserva Biológica do Guará & DF & Rebio & Estadual \\
\hline Reserva Biológica do Jaibá & MG & Rebio & Estadual \\
\hline Reserva Biológica do Rio Descoberto & DF/GO & Rebio & Federal \\
\hline
\end{tabular}




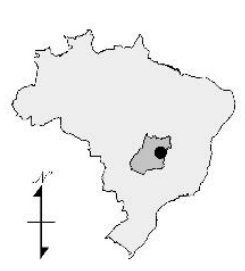

Situação Fundiária: Não regularizado Plano de Manejo: Näo

RESERVA BIOLÓGICA

DA CONTAGEM
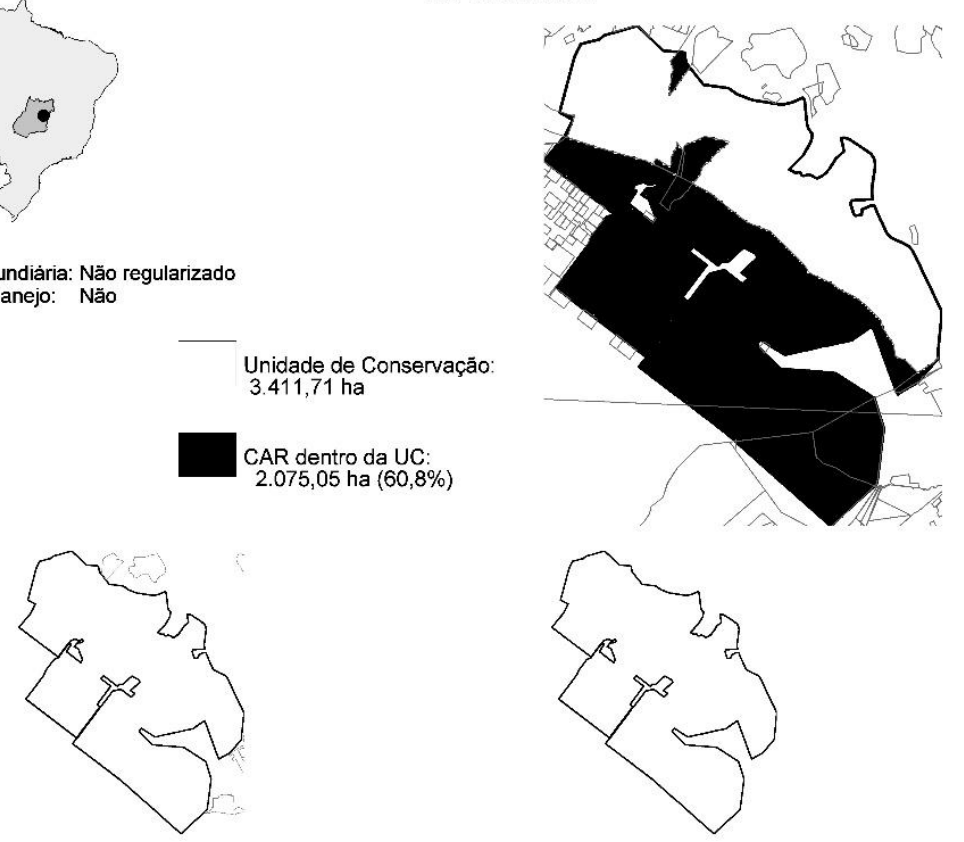

SIGEF Particular:
0,03 ha $(0 \%)$

Terra Indigena:
$0(0 \%)$

Assentamento Rural:
$0(0 \%)$

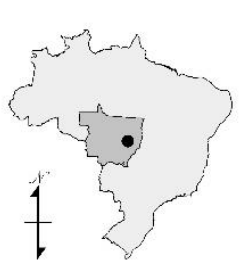

Situação Fundiária: Plano de Manejo: Não

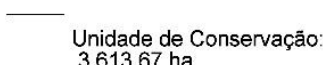
$3.613,67$ ha

CAR dentro da UC

RESERVA BIOLÓGICA DE CULUENE
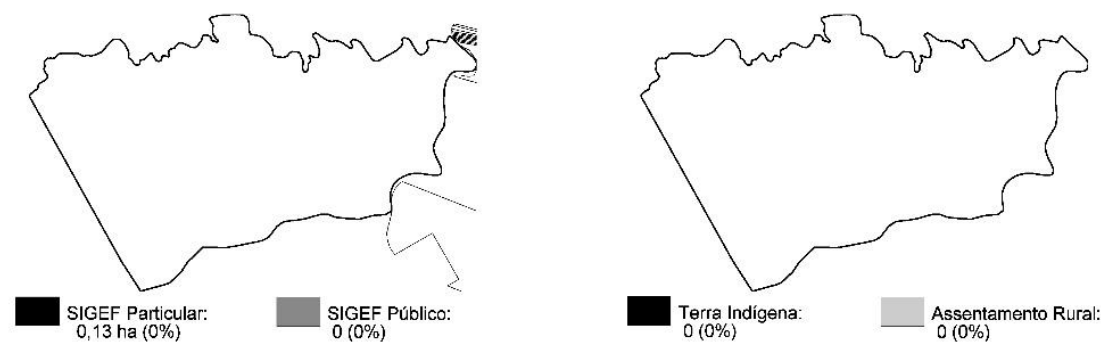


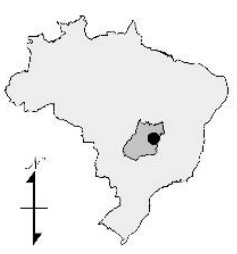

Situaçāo Fundiária: Plano de Manejo:

Unidade de Conservação: 53,92 ha

CAR dentro da UC: $53,92 \mathrm{ha}(100 \%)$

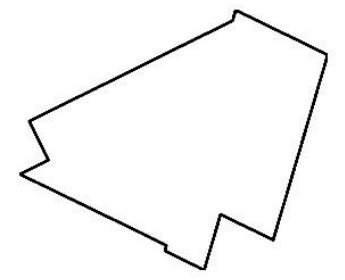
SIGEF Particular:
$0(0 \%)$$\quad$ SIGEF Público

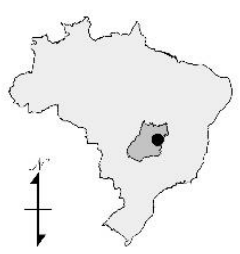

Situação Fundiária: Não regularizado Plano de Manejo: Não

Unidade de Conservação 536,75 ha

CAR dentro da UC:
536,75 ha $(100 \%)$

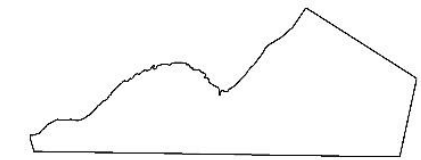

SIGEF Particular:
SIGEF Público:
RESERVA BIOLÓGICA

DO CERRADÁO
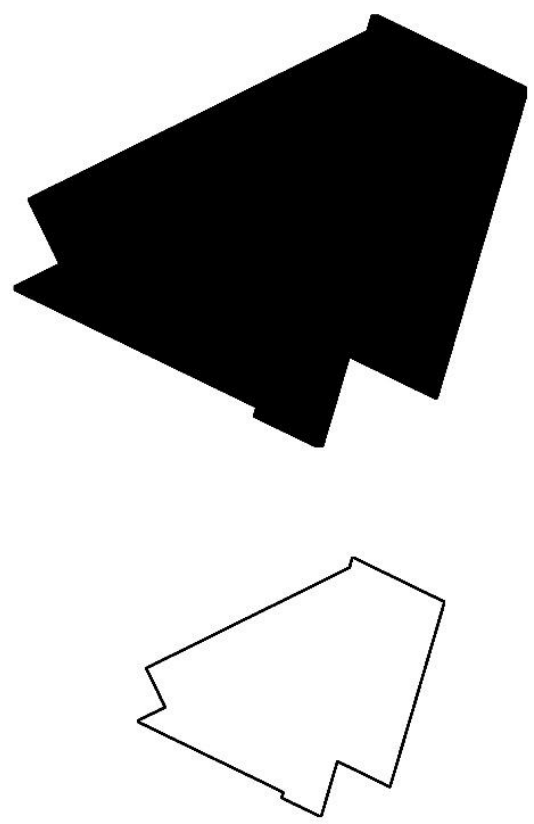

Terra Indígena: $\quad \begin{gathered}\text { Assentamento Rural: } \\ 0(0 \%)\end{gathered}$
$0(0 \%)$
RESERVA BIOLÓGICA

DO GAMA
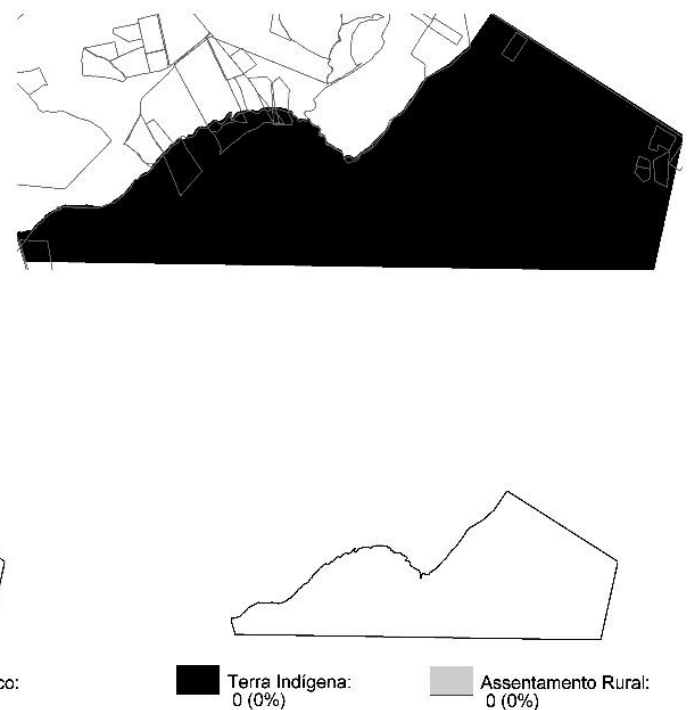
RESERVA BIOLÓGICA

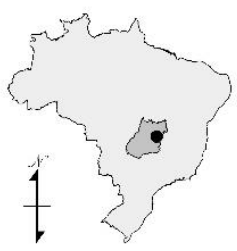

DO GUARÁ

Situaçăo Fundiária: Parcialm. regularizado Plano de Manejo: Não

\section{Unidade de Conservaçăo: 145,37 ha \\ CAR dentro da UC: \\ 145,37 ha $(100 \%)$}

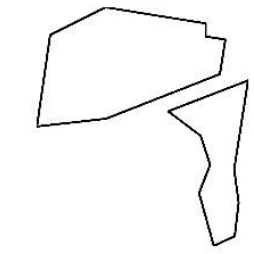

$\underset{0(0 \%)}{\text { SIGEF Particular: }}$

\begin{tabular}{|} 
SIGEF Público: \\
$0(0 \%)$
\end{tabular}
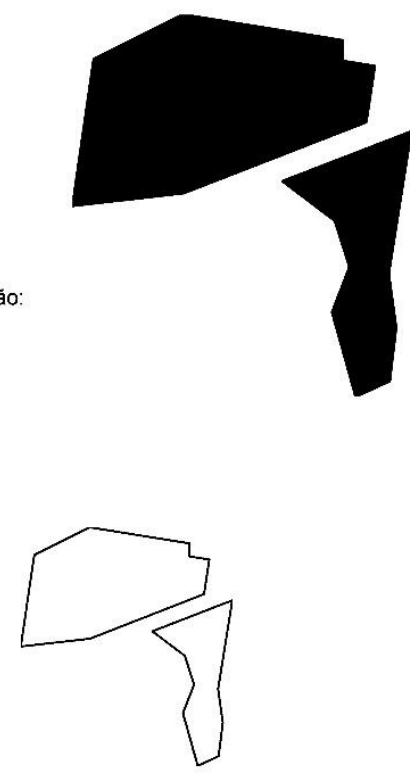

Terra Indígena
$0(0 \%)$

Assentamento Rural:
$0(0 \%)$

RESERVA BIOLÓGICA

DO JAIBBA
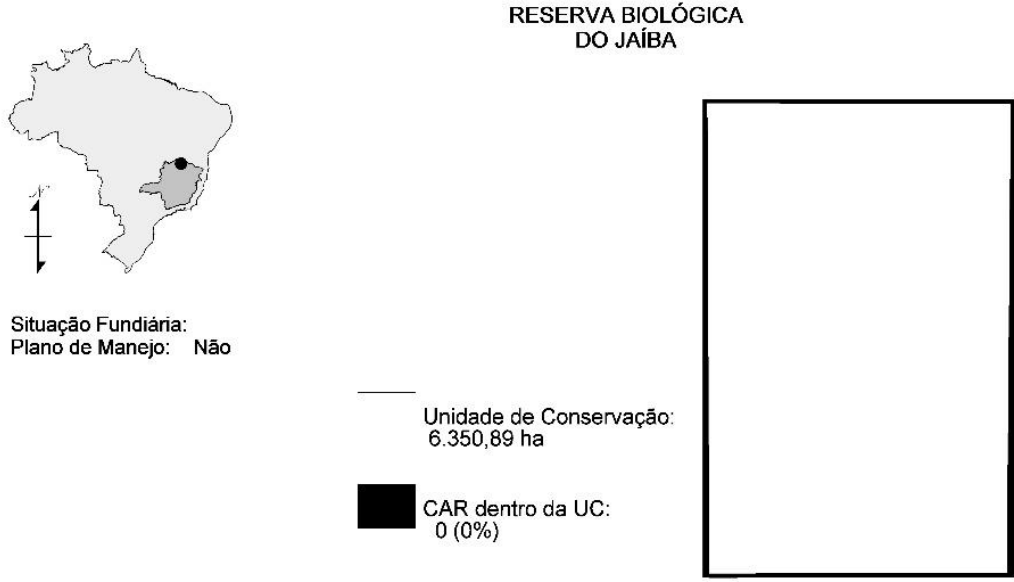

Situação Fundiária:

Plano de Manejo: Não

Unidade de Conservação

$0(0 \%)$

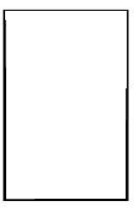

Terra Indigena

SIGEF P
$0(0 \%)$

SIGEF Público:

$0(0 \%)$

Assentam
$0(0 \%)$ 


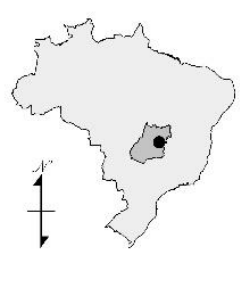

RESERVA BIOLOGICA

Situação Fundiảria:

Plano de Manejo: Sim
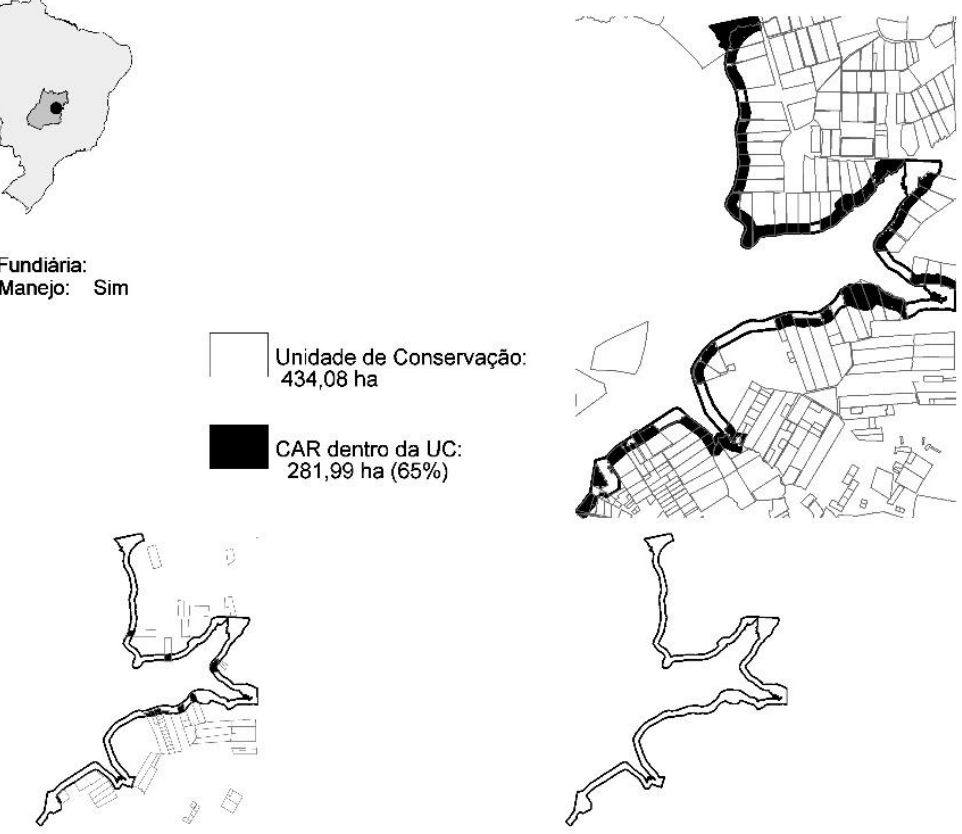

Unidade de Conservação:

281,99 ha $(65 \%)$

SIGEF Particular:
32,46 ha $(7,35 \%)$

Terra Indigen
$0(0 \%)$

Assentamento Rural:
$0(0 \%)$ 
ANEXO 5 - Mapas das reservas extrativistas do bioma Cerrado

\begin{tabular}{|c|c|c|c|}
\hline Reserva Extrat. Chapada Limpa & MA & Resex & Federal \\
\hline Reserva Ext. de Recanto das Araras de Terra Ronca & GO & Resex & Federal \\
\hline Reserva Extrat. Extremo Norte do Estado do Tocantins & TO & Resex & Federal \\
\hline Reserva Extrat. Lago do Cedro & GO & Resex & Federal \\
\hline Reserva Extrat. Marinha do Delta do Parnaíba & PI & Resex & Federal \\
\hline Reserva Extrat. Mata Grande & MA & Resex & Federal \\
\hline
\end{tabular}




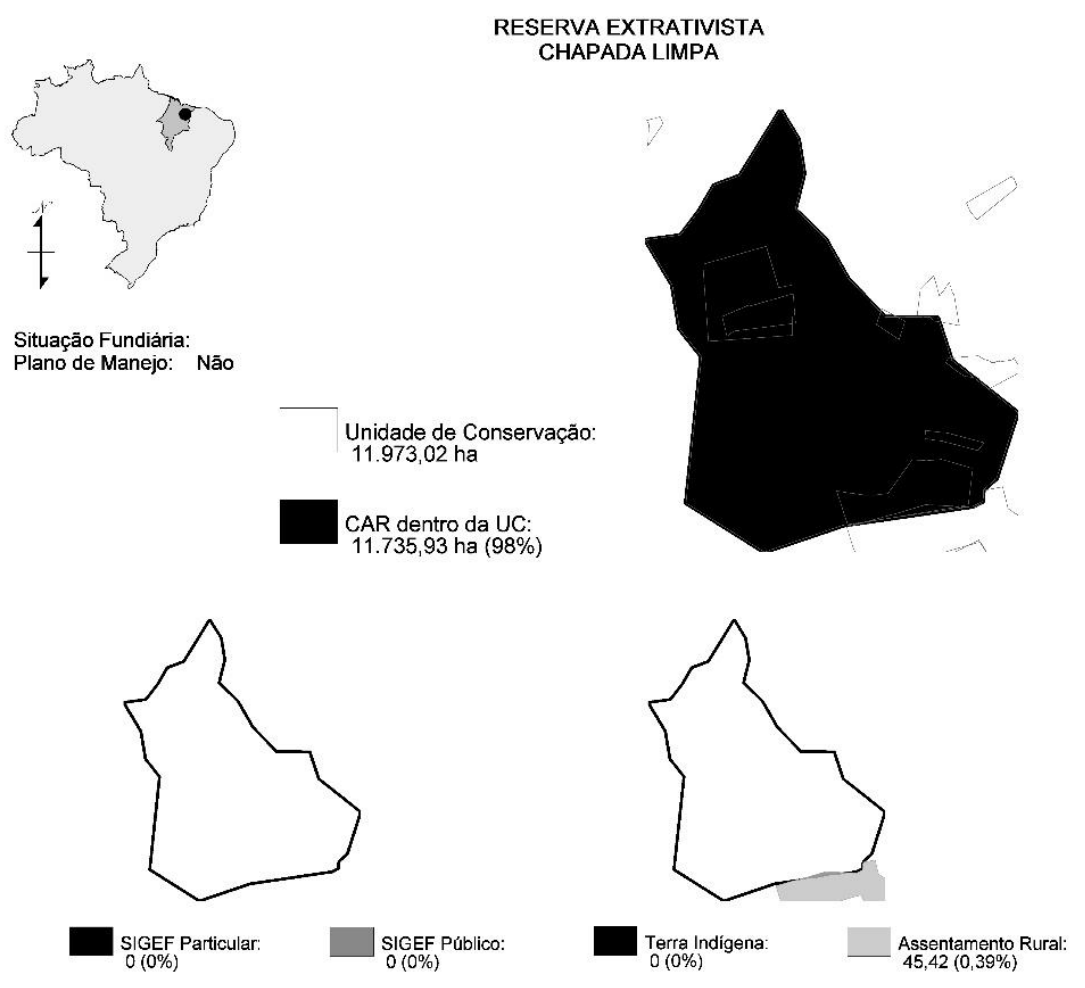

RESERVA EXTRATIVISTA

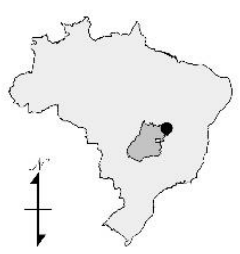

DO RECANTO DAS ARARAS DE TERRA RONCA

Situação Fundiária: Não regularizado Plano de Manejo: Nāo

Unidade de Conservação:
$12.349,33$ ha

CAR dentro da UC:

12.349,33 ha $(100 \%)$

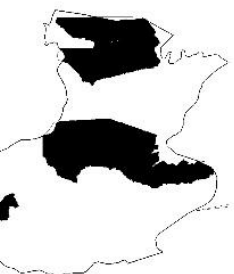

SIGEF Particular:
$3.639 ., 9$ ha $(29,24 \%)$
SIGEF Público:
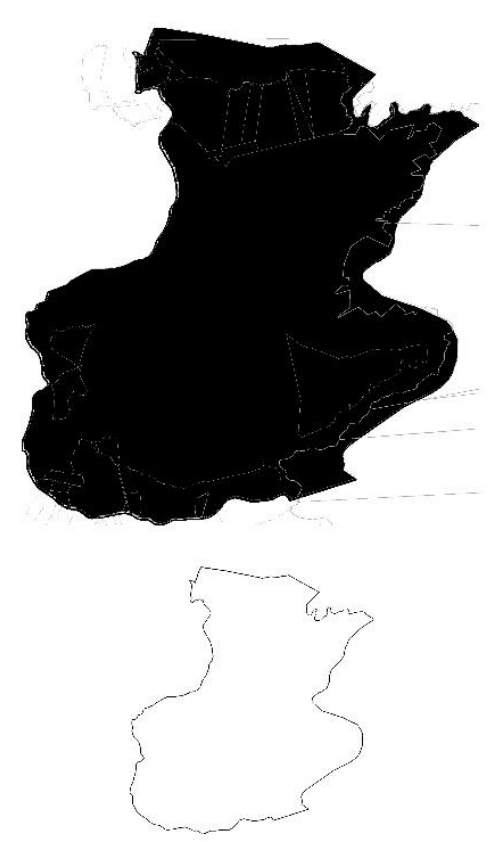

Terra Indigena
$0(0 \%)$ 

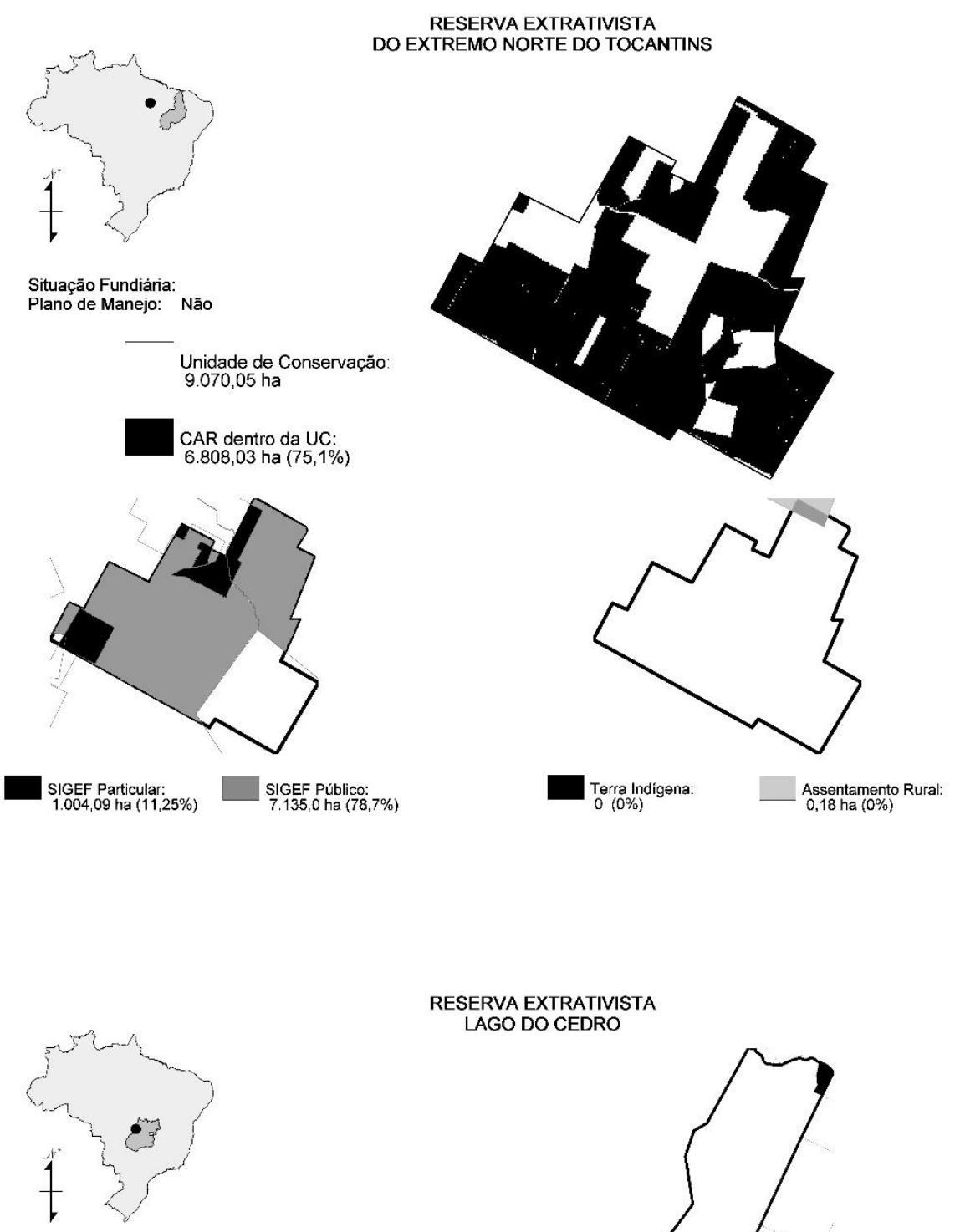

RESERVA EXTRATIVISTA

LAGO DO CEDRO

Situação Fundiária: Não regularizado Plano de Manejo: Não
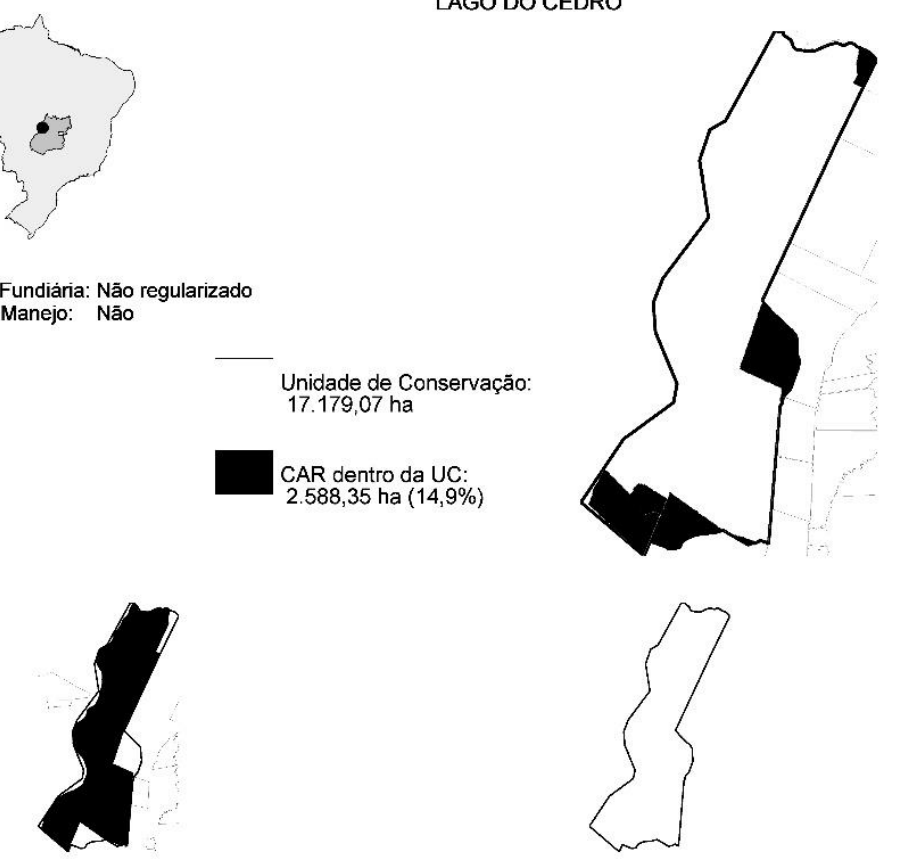

SIGEF Particular:
$14.838,61$ ha $(85,30 \%)$$\quad \begin{aligned} & \text { SIGEF Público: } \\ & 0(0 \%)\end{aligned}$

Terra Indigena:
$0(0 \%)$ 

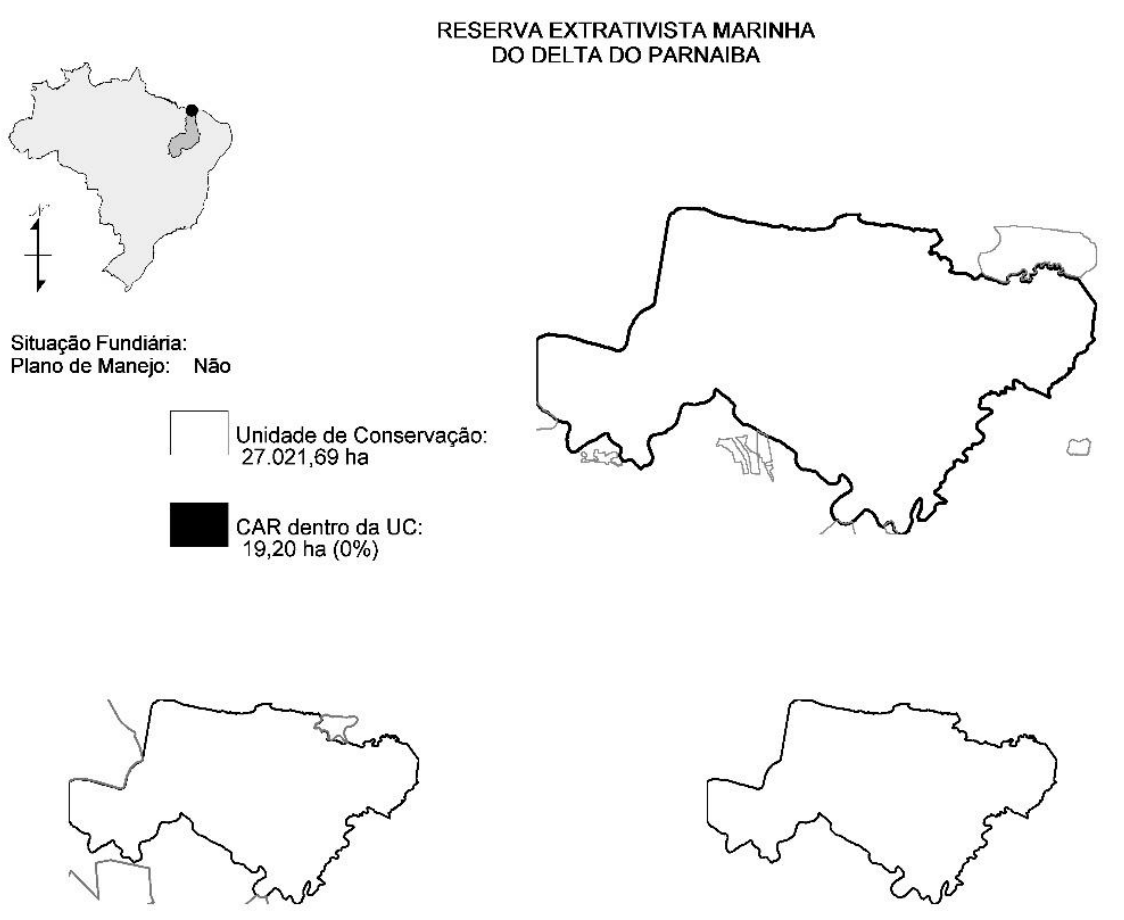

SIGEF Particular:
3,13 ha $(0 \%)$

Terra Indigena: $\quad \longrightarrow$
$0(0 \%)$

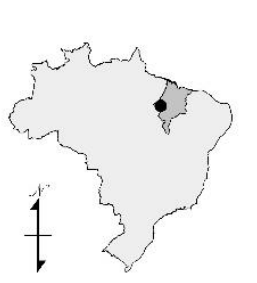

RESERVA EXTRATIVISTA

MATA GRANDE

Situação Fundiária: Não regularizado Plano de Manejo: Não

\section{Unidade de Conservaçăo:
$11.431,53$ ha}

CAR dentro da UC:

11.242,70 ha $(98,3 \%)$
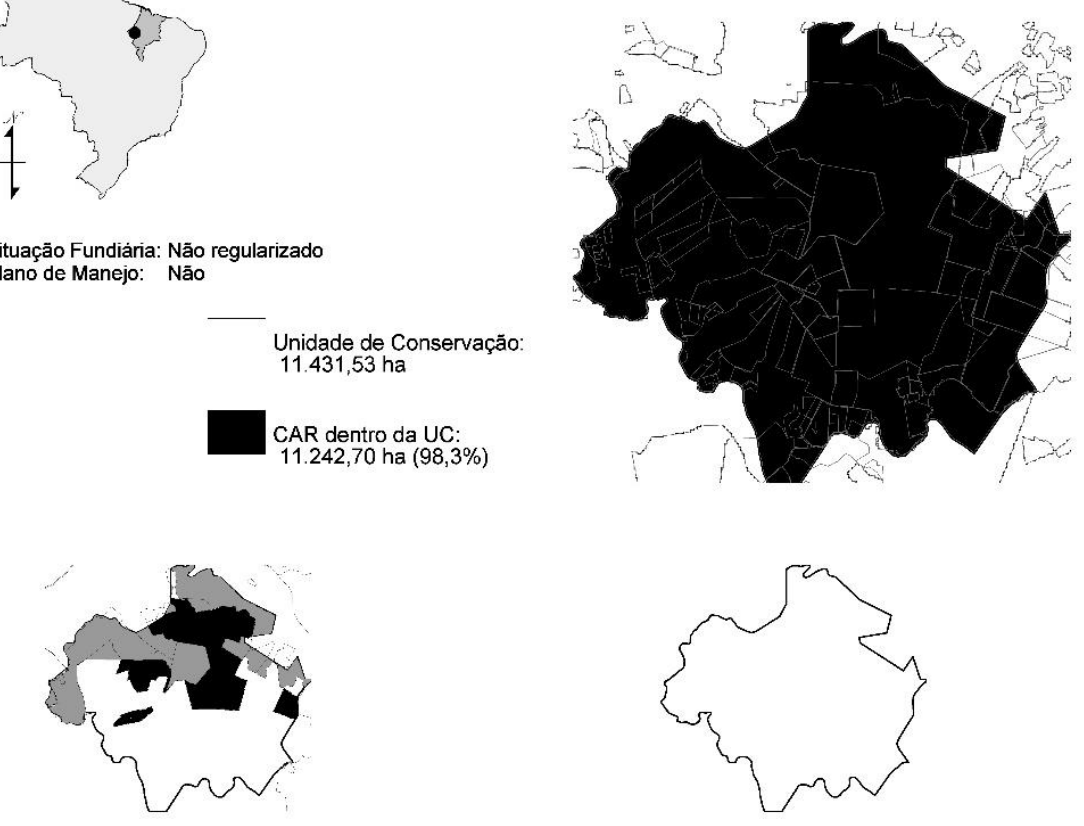

SIGEF Particular:
$4.161,98$ ha $(36,98 \%)$

SIGEF Público:
$3.116,70$ ha $(27,69 \%)$

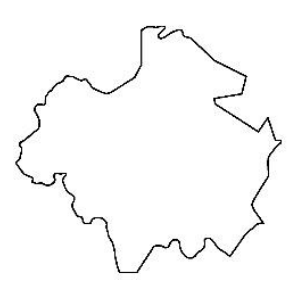

Terra Indigena
$0(0 \%)$

Assentamento Rural:
$0(0 \%)$ 